\title{
Pavimentos
}

\section{huellas fenomenológicas, registros arqueológicos y planos de referencia}

Departamento de Proyectos Arquitectónicos Escuela Técnica Superior de Arquitectura Universidad Politécnica de Madrid
Autor:
D. José Francisco García-Sánchez, arquitecto
Director:
D. Luis Martínez Santa-María, dr. arquitecto 




\section{Pavimentos}

huellas fenomenológicas, registros arqueológicos y planos de referencia

Departamento de Proyectos Arquitectónicos Escuela Técnica Superior de Arquitectura Universidad Politécnica de Madrid

Autor:

D. José Francisco García-Sánchez, arquitecto

Director:

D. Luis Martínez Santa-María, dr. arquitecto 
Tribunal nombrado por el Mgfco. y Excmo. Sr. Rector de la Universidad Politécnica de Madrid, el día:

\section{Presidente D.}

Vocal D.

Vocal D.

Vocal D.

Secretario D.

Realizado el acto de defesa y lectura de Tesis el día en la Escuela Técnica Superior de Arquitectura de Madrid

Calificación:

EL PRESIDENTE

LOS VOCALES

EL SECRETARIO 


\section{Índice \\ Organización y estructura}


Índice

Agradecimientos

Resumen

Abstract

Objetivos

Estado de la cuestión

Método. Atlas. Constelaciones e intersecciones. Fuentes

Organización y estructura del índice

\section{BLOQUE I. Referentes}

1. Introducción. Suelos y pavimentos

Introducción / Suelo exterior / Primer elemento / Superficie / La querencia de lo visual / Patrones geométricos / El pavimento como campo de intercambio comercial

2. El suelo cósmico. El pavimento y la escala Introducción / El suelo sin gravedad / Power of Ten / San Marcos liberando al esclavo, Tintoretto / Traslación del Cuerpo de San Marcos, Tintoretto / El Partheon de Roma / Unité d'Habitation de Marseille de Le Corbusier / El pavimento y la forma / El Museo Guggenheim de New York / Roberto Burle Marx

3. El pavimento en la representación del espacio. Perspectiva central y movimiento Introducción / Perspectiva central. Renacimiento / El pavimento en Heinrich Tessenow

4. Pie fenomenológico. El ojo a ras del suelo. Erotismo háptico Introducción / Pies y zapatos / Antropometría del pie / El pavimento como espacio sonoro y campo de baile

5. El suelo habitado por el cuerpo. Arquitectura de contacto

El suelo habitado / Horror vacui. El pavimento rozado por los artistas / Suelo hundido. Conversation Pit /

Plataformas / Ceremonia del té

6. El suelo esponjoso. La densidad perdida

Introducción / Suelos lapidarios / Cerámica / Madera

7. Círculos de piedra. Huellas. Pavimentos en el paisaje. Eras de trilla y Artistas en el Paisaje Introducción / Círculos de piedra. Eras de trilla / Círculos de piedra

8. El pavimento como soporte narrativo. El suelo parlante Introducción / El suelo como soporte narrativo / Duomo di Siena / Laberintos / Poder. Suelo sobre el suelo

9. El pavimento inclinado. Anhelo natural Introducción / Livio Vaccini y Stonehenge / La capilla de Ronchamp (1950-1955). Le Corbusier.

10. El pavimento textil. Alfombras y superposiciones Introducción / Encuentro del cuerpo de San Marcos, Tintoretto / Revestimientos textiles / Carpet (1927) Paul Klee / Bauhaus / Adolf Loos. El dormitorio de mi esposa / Suelo sagrado 


\section{BLOQUE II. Casos de estudio}

11. El pavimento preciso. El suelo como plano de referencia.

11.1. Introducción.

11.2. El pavimento en Mies van der Rohe. El suelo como plano de referencia.

11.3. Casa Tugendhat (1928-1929). Mies van der Rohe.

11.4. Casa para una pareja sin hijos (1931). Mies van der Rohe.

11.5. Casa Lemke. Berlín. (1932-1933). Mies van der Rohe.

11.6. Casas Patio. Casas de Campo de ladrillo. Casa tres patios (1934-1938). Mies van der Rohe.

12. El pavimento y el color. El suelo y la vida.

12.1. Introducción. Color. Las bodas de Caná (1563). San Jerónimo en su Lectorium (1475)

12.2. El pavimento cerámico en la Arquitectura de Gio Ponti. Cerámica y azul.

Introducción / Cerámica / Pavimento y ropajes. Una piccola casa ideale (1934)

12.3. Dos casas en Caracas: Mansión Planchart 'El Cerrito' (1953-1960) y Mansión Arreaza

'Villa Diamantina'

(1954-1958). Metáforas y simpatías. Atmósfera telúrica / Cámara de Comercio de Córdoba (1950). José María García de Paredes y Rafael de la Hoz Arderius

12.4. Hotel Parco dei Principi (1960-1961) y Oficinas Salzburger (1976). Palimpsestos contemporáneos

13. El pavimento en Venecia. Metáforas acuosas

13.1. Introducción

13.2. Basílica de San Marcos. Caminar sobre el agua

Introducción. Plaza de San Marcos / Suelo y agua. Metáforas acuosas / Basílica de San Marcos.

Caminar sobre el agua / Pavimento imperfecto. El tiempo y la memoria

13.3. El Lavatorio (1548). Jacopo Robusti Tintoretto

13.4. Tienda Olivetti en Venecia (1957-1958). Carlo Scarpa. El pavimento como infraestructura

13.5. Fundación Querini Stampalia en Venecia (1961-1963). Canales interiores

Introducción / Nuevo atrio / Portergo / Aula Luzzatto / Contactos y encuentros.

14. El pavimento en el umbral. Entre dos mundos

14.1. Introducción

14.2. Team 10: pavimentos in-between. La calle y el salón / Introducción / Parques de Aldo van Eyck

14.3. Upper Lawn, Wiltshire, Gran Bretaña (1959-1962). Alison y Peter Smithson.

Pavimentos encontrados

14.4. Villa Mairea en Noormarkku (1937-1939). Alvar Aalto. Límites difusos

14.5. Villa Snellman en Djursholm (1917-1918). Estocolmo. Gunnar Asplund. Umbral pavimentado

14.6. Tribunal del Condado de Lister en Sölvesborg (Suecia) (1917-1921). Gunnar Asplund. Simetría incierta

15. El pavimento y el fragmento. El tiempo y la memoria

15.1. Introducción

15.2. Casa Experimental de vacaciones en Muuratsalo (1952-1954). Alvar Aalto. Atrio cerámico

15.3. Intervención paisajística en los caminos de subida a la Acrópolis (1953-1958). Dimitris Pikionis. Alfombras pétreas 


\section{Agradecimientos}

Es difícil saber con seguridad para lo que se escribe: no sabemos si escribimos para decirle algo a alguien o para oírnoslo decir a nosotros mismos. Porque la lectura de los demás, incluso la escucha del público es siempre hipotética. De los dos actores necesarios para que se produzca el mensaje en la comunicación escrita, el emisor es una presunción ineludible y la presencia del receptor es, a veces, un milagro. Aunque quien esté leyendo esto ahora se pueda sonreir.

La Arquitectura, como el amor, no se dice: se hace. $\mathrm{Y}$ una Tesis, como literatura escrita, no se hace: se dice. Se escribe. Si esta Tesis consigue conmover, emocionar o descubrir algo nuevo a alguien, todo el trabajo habrá merecido la pena.

Por todo ello, esta Tesis te la dedico a ti, querido lector.

\section{Financiación}

1. El autor de la Tesis doctoral ha recibido una financiación pública a través de un Contrato pre-doctoral del Plan Propio I+D+l de la Universidad Politécnica de Madrid, en una convocatoria competitiva según la resolución rectoral de 9 de julio de 2015, habiendo sido suscrito el contrato el 1 de marzo de 2016. La Tesis se ha realizado en el Departamento de Proyectos Arquitectónicos.

2. La estancia internacional de investigación realizada en l'Università degli Studi di Roma La Sapienza para obtener la mención de Doctorado Internacional se ha realizado gracias al Plan Propio I+D+l 2019 «Ayudas al personal investigador en formación predoctoral para realizar una estancia de investigación internacional igual o superior a tres meses» de la Universidad Politécnica de Madrid. 
Pavimentos: huellas fenomenológicas, registros arqueológicos y planos de referencia 


\section{Resumen}

La tesis 'Pavimentos: huellas fenomenológicas, registros arqueológicos y planos de referencia' pretende reflexionar sobre la evolución de la arquitectura del Movimiento Moderno a través de los planteamientos teóricos y de las estrategias proyectuales tomando como tema central suelo pavimentado, entendido como el revestimiento artificial construido sobre el suelo natural o sobre una solera.

El ámbito de estudio se centra en algunas obras del Movimiento Moderno del tercio central del siglo XX. Que abarcan algunas obras de la modernidad ortodoxa, pero sobre todo algunas obras seleccionadas de la segunda generación del Movimiento Moderno. Se estudiarán ejemplos de Mies van der Rohe, Gio Ponti, Carlo Scarpa, Alison y Peter Smithson, Alvar Aalto, Erik Gunnar Asplund o Dimitris Pikionis.

La tesis construye un diálogo comparado entre épocas diversas estableciendo como hilo conductor el pavimento —entendido como 'fragmento' o como 'elemento'- y su relación con el resto de elementos que conforman el espacio arquitectónico como son, por ejemplo, el techo, la estructura, los huecos, o incluso el mobiliario y el ajuar doméstico. El trabajo de investigación también estudia la presencia del pavimento en el espacio imaginado de la pintura, en la fotografía, en la literatura o en el cine.

Los pavimentos, además, desempeñan un papel fundamental en la percepción de un lugar, tanto en los ámbitos exteriores como en los recintos interiores ya que los revestimientos horizontales de los recintos cerrados y los suelos exteriores se ven influidos por la materialidad y apariencia de sus pavimentos. $Y$ es que a veces olvidamos donde se posan nuestros pies. La mirada y los ojos se deslizan sobre el plano del suelo anhelando respuestas.

La tesis estudia cómo el suelo pavimentado se convierte en un elemento que participa en la génesis del proyecto moderno, asumiendo que es depositario de una espacialidad propia. Esta idea de suelo-espacio, sitúa al plano del suelo pavimentado en una dimensión que va más allá de ser un silente elemento arquitectónico estático. De este modo, el suelo adquiere un espesor que no se limita a la profundidad del pavimento, sino que alcanza una verdadera dimensión espacial.

El trabajo también analiza la condición fenomenológica que tiene el suelo pavimentado al tratarse de una arquitectura de contacto. La relación íntima que se produce con el pie, con el zapato o con los cuerpos se debe a que la textura, la materialidad, la rugosidad, la sonoridad o la temperatura vinculan al pavimento irremediablemente a lo sensual.

El trabajo de investigación estudia la condición del suelo pavimentado como huella arqueológica. Cada pisada sobre su superficie nos remite a una huella de su memoria, a un pasado reciente y cada nuevo paso presagia un porvenir inminente, un futuro inesperado. Desplazarse sobre un pavimento es reconocerse inmerso en un campo de juego que establece vínculos con el espacio y con el tiempo. 
Pavimentos: huellas fenomenológicas, registros arqueológicos y planos de referencia 


\section{Abstract}

The thesis 'Flooring: phenomenological footprints, archaeological traces and reference plans' intends to reflect on the evolution of the architecture in the Modern Movement through theoretical approaches and project strategies, taking as a central theme paved floor, understood as the artificial covering built on the natural soil or on a slab.

The scope of study focuses on some works of the Modern Movement of the central third of the twentieth century. They cover some works of orthodox modernity, but above all some works selected from the second generation of the Modern Movement. Examples of Mies van der Rohe, Gio Ponti, Carlo Scarpa, Alison and Peter Smithson, Alvar Aalto, Erik Gunnar Asplund or Dimitris Pikionis will be studied.

The thesis constructs a comparative dialogue between different periods, establishing as the thread the flooring- understood as a 'fragment' or as an 'element' - and its relationship with the rest of the elements that make up the architectural space such as, for example, the ceiling, the structure, gaps, or even furniture and household furniture. The research work also studies the presence of flooring in the imagined space of painting, in photography, in literature or in the cinema.

In addition, flooring play a fundamental role in the perception of a place, both in the exterior areas and in the interior enclosures since the horizontal coverings of the indoor and the outdoor spaces floors are influenced by the materiality and appearance of their flooring . And, sometimes, we forget where our feet rest. The gaze and eyes glide over the floor plane yearning for answers.

The thesis studies how the paved floor becomes an element that participates in the genesis of the modern project, assuming that it is a depository of its own spatiality. This idea of floor-space places the paved floor plan in a dimension that goes beyond being a silent static architectural element. In this way, the ground acquires a thickness that is not limited to the depth of the flooring, but reaches a true spatial dimension.

The work also analyzes the phenomenological condition of paved floor as it is a contact architecture. The intimate relationship that occurs with the foot, with the shoe or with the bodies is due to the texture, materiality, roughness, loudness or temperature that inevitably link the pavement to the sensual.

The research paper studies the condition of the paved soil as an archaeological footprint. Each step on its surface refers us to a trace of its memory, a recent past and each new step foreshadows an imminent future, an unexpected future. To move on a pavement is to recognize yourself immersed in a playing field that establishes links with space and time. 
Pavimentos: huellas fenomenológicas, registros arqueológicos y planos de referencia 


\section{Objetivos}

1. La tesis se propone el análisis crítico, teórico y gráfico de los pavimentos de algunas obras de arquitectura del Movimiento Moderno referidas al tercio central del siglo XX.

2. La tesis propone responder a cómo concibieron el proyecto del suelo pavimentado algunos de los maestros del Movimiento Moderno, sobre todo los referidos a la segunda generación. ¿Existe una ruptura de los arquitectos del Movimiento Moderno con este elemento? ¿se produce una re-elaboración de las lecciones de la arquitectura clásica? o... ¿toman sus modelos de la técnicas constructivas heredadas de la arquitectura popular o vernácula, desde cierta nostalgia romántica?.

3. Se estudiará cuánto el suelo pavimentado, en los diferentes ejemplos que se analizarán en la tesis, ayuda a diluir los límites entre el interior y el exterior.

4. En el trabajo de investigación se estudiará el pavimento desde una dimensión espacial, tectónica, infraestructural y, desde luego, fenomenológica, en cuanto el suelo puede ser considerado como una arquitectura de contacto por su relación íntima con la especie.

5. La investigación también estudiará la relación entre los viajes iniciáticos que algunos de los maestros realizaron por Italia, Grecia y el Mediterráneo, con la voluntad de concebir el suelo pavimentado como una huella arqueológica, como un palimpsesto moderno construido desde el fragmento.

6. La tesis estudiará el pavimento en ejemplos de construcciones de distintas épocas, pero también se producirá una investigación de la presencia del suelo pavimentado en el espacio imaginado de la pintura, en la fotografía, en la literatura o en el cine, con la voluntad de producir una fecundación cruzada entre distintas disciplinas.

7. El trabajo analizará también la evolución de la representación gráfica del pavimento desde la aparición de la perspectiva en el Renacimiento, los suelos dibujados en el espacio pintado figurativo, hasta los recursos gráficos empleados por los arquitectos de la modernidad —la línea trémula de los dibujos de Pikionis, la precisión germánica de los pavimentos de Mies van der Rohe, el cromatismo de Carlo Scarpa o Gio Ponti, la tradición vernácula de Fernando Távora, el racionalismo irónico de Le Corbusier o el clasicismo nórdico de Gunnar Asplund o Alvar Aalto, entre otros-y el amplio imaginario de la cultura y el arte contemporáneo del siglo XX — los artistas vinculados al land-art, el expresionismo abstracto o la producción gráfica de la cultura pop de la década de 1960, entre otros.

8. El formato de la tesis se presenta como un atlas de pavimentos ya que, incluidas entre los ensayos, se intercalarán unas láminas donde una constelación de imágenes, de distintas disciplinas y procedencias, apoyarán, con un lenguaje visual, el discurso teórico y crítico de la tesis. Por tanto, el trabajo será una memoria crítica visual, un glosario que sirva de guía a quien decida hoy proyectar y construir arquitectura contemporánea. 
Pavimentos: huellas fenomenológicas, registros arqueológicos y planos de referencia 


\section{Estado de la cuestión}

El pavimento no ha sido objeto de grandes debates a lo largo de la historia de la arquitectura, más allá de estudios técnicos sobre su construcción, su composición o su durabilidad. Pero también es cierto que el suelo pavimentado sí ha sido, para algunos teóricos, objeto de análisis parcial de algún proyecto concreto o de alguna figura muy vinculada con el plano de suelo.

Para ello, hagamos un breve repaso sobre lo escrito sobre pavimentos por algunos autores seleccionados:

Marco Vitruvio Polión (c80-c15 a.C.) en el 'Capítulo Primero' del Libro VIII «De los pavimentos» en De architectura (c15 a.C.) (Los Diez Libros de Arquitectura), dice:

«En primer lugar comenzaré por el 'pavimento de cascotes' [ruderación], que es el paso previo para el enlucido, con el fin de que se haga con sumo cuidado y previsión y lograr así una sólida base. Si se ha de echar sobre el suelo, debe averiguarse previamente si el suelo es completamente sólido; posteriormente se nivelará y se extenderá una capa de cascotes y gravilla. Si se trata de un suelo de tierra de relleno, en todo o en parte, se consolidará y se apisonará con todo cuidado. En el caso de los entramados, téngase muy en cuenta que no hay abajo el pavimento ninguna pared de las que se elevan hasta la parte superior; si la hubiere, debe rebajarse y así se podrá entarimar encima de ella. De lo contrario, cuando se solidifique al secarse el entramado o bien al asentarse debido al pandeo, si queda en pie la pared por la solidez de su construcción, necesariamente ocasionará en el pavimento hendiduras a derecha y a izquierda y en toda su longitud.

Igualmente se ha de poner todo el cuidado en no cambiar tablas de madera de "ésculo» [El 'aesculo' es una planta arbórea con hojas pecioladas. Algunos autores lo identifican con el 'roble de invierno', la encina blanca,... . con madera de encina, pues la de encina, cuando se humedece, acaba arqueándose y agrietando los pavimentos. Si no hay a mano madera de ésculo y por necesidad nos vemos obligados a utilizar madera de encina, procédase de la siguiente manera: se serrará en planchas de poco grosor, finas, pues cuanto menos dureza ofrezcan, más fácilmente podremos unirlas con clavos; clávense dos clavos en la parte extrema de cada una de las vigas para que resulte imposible que se arqueen, levantándose sus partes extremas. No tratamos sobre la madera de cerro, de haya, ni de fresno, pues no son muy duraderas. Una vez colocado el entarimado, extiéndase por encima, si hay a mano, una capa de helecho o bien de paja, con objeto de proteger la madera frente a los problemas que ocasiona la cal.

Posteriormente se extenderá encima una capa de cascote del tamaño de un puño. Colocada la capa de cascotes, se extenderá otra capa de ripios; si se trata de ripios recientes de piedra o de ladrillo molido, se mezclará una parte de cal y tres de ripios; si se trata de ripios procedentes de ruinas o demoliciones, se mezclarán cinco partes de ripios con dos de cal. A continuación se apisonará repetidamente la capa de cascotes utilizando mazos de madera, para que quede perfectamente firme; este trabajo se hará mediante cuadrillas de hombres que ocupen todo el ancho de la capa, hasta que quede con un grosor de al menos nueve pulgadas. 
Sobre la capa de cascotes se extenderá otra de "restos arcillosos», con la siguiente mezcla: tres partes de polvo de ladrillo con una parte de cal, que formará un lecho de no menos de seis dedos. Sobre este lecho se extenderá el pavimento perfectamente nivelado, bien sea de losetas de mármol, o bien de mosaico.

Una vez colocado, daremos al pavimento una adecuada inclinación y se pulirá hasta que -si se trata de losetas- no quede ninguna arista en las baldosas, bien tengan forma de rombo, de triángulo, de cuadrado o de hexágonos, sino que la unión de las junturas esté nivelada una con otra ofreciendo una superficie totalmente plana; si se trata de pavimento de mosaicos, todos sus bordes deben quedar planos ya que si no fuera así su pulimento no habrá sido correcto. Los pavimentos de azulejos colocados "a espiga», como los que se usan en Tívoli, deben nivelarse con sumo cuidado, ajustándolos de modo que no haya huecos ni salientes sino que queden perfectamente alisados y pulidos; sobre los azulejos pulidos se derramará polvo de mármol y se extenderá encima una capa de cal y de arena.

Los pavimentos que vayan a quedar al aire libre deben adaptarse a tal finalidad, pues al hincharse por la humedad los entramados, o al disminuir su volumen debido a la sequedad, o bien al combarse, sufren variaciones que ocasionan serios problemas en los pavimentos; además, las escarchas y los hielos reducen su durabilidad. Si nos vemos obligados a su utilización, con el fin de que no tengan ningún problema debe procederse así: colocadas las vigas, póngase sobre ellas otras atravesadas, bien sujetas con clavos, lo que posibilitará un doble entablado al entramado; posteriormente, se mezclará una tercera parte de piedras y ladrillos molidos con ripios nuevos, más dos partes de cal que darán un compuesto de cinco elementos para formar el mortero.

Cuando se haya echado una primera capa de cascotes en seco, cúbrase con otra capa de ripios, que, bien apisonados, deben tener un grosor no menor de un pie; colocada esta capa, como antes se ha descrito, se extenderá el pavimento con pequeñas piedras de mosaico de dos dedos de espesor aproximadamente y con un desnivel de dos dedos por cada diez pies; si se prepara todo correctamente y queda todo perfectamente alisado, el pavimento resultará impecable. Para que el mortero que va entre las junturas no sufra daños provocados por las heladas, se cubrirá cada año con heces de aceite, antes del invierno, y así se evitará que penetren las escarchas.

Pero si se quiere conseguir un resultado más cuidadoso, colóquense unas baldosas de dos pies unidas entre sí encima de la capa de cascotes, con mortero; las baldosas tendrán en cada uno de sus lados unas hendiduras o estrías de un dedo de anchura. Estas estrías se rellenarán con cal mezclada con aceite y las junturas bien compactadas entre sí quedarán totalmente estregadas. Ya que, cuando se endurezca la cal, adhiriéndose a las estrías, impedirá el paso del agua o de cualquier otro líquido a través de las junturas. Cuando quede totalmente solado se extenderá encima una capa de trozos de ladrillo, que se apisonará con pilones. Sobre ella se colocarán, con el desnivel que antes hemos dicho, unas grandes losas o bien ladrillos molidos puestos en forma de espiga. Si se hace todo de este modo, los pavimentos permanecerán en buen estado, durante mucho tiempo» [1]. 
León Battista Alberti (1404-1472) en el «Capítulo XI» del Libro I: El trazado, de su libro De Re Aedificatoria (1452), dice:

«Y la parte que pisan los que caminan sobre ella se llamará pavimento y piso. Ahora bien, las cubiertas más altas a cielo abierto, que están para contener la lluvia, en otro lugar se discutirá si pueden funcionar como pavimento.

Por otro lado, las techumbres a cielo abierto, aunque puede que las superficies sean llanas, no serán nunca paralelas al pavimento que recubrieren, sino que siempre estarán inclinadas y en pendiente por algún punto para desaguar el agua de las lluvias» [2].

En el «Capítulo XVI» del Libro II: Los materiales, dice:

«Un tipo de pavimento para estar bajo techo, que alaban sobremanera a causa de no ser húmedo en absoluto, aconseja Varrón que se haga de la manera siguiente. Excava hasta una profundidad de dos pies y explana el piso a golpes de maza, y encima dispón un pavimento de escombro o de ladrillos cocidos; deja expeditos orificios, para que pueda salir al exterior la humedad por canales propios; amontona carbón y, una vez apisonado y apretado, aplica encima una masa de medio pie de espesor hecha con arena, cal y ceniza.

Las consideraciones que hemos hecho hasta ahora las hemos obtenido del estudio de Plinio y, sobre todo, de Vitruvio. A continuación voy a referir lo que de relativo a los pavimentos he podido recopilar a partir de la observación aplicada y concienzuda de las obras de los antiguos; de las que admito que he aprendido muchísimo más que de los escritores. Y voy a comenzar por la capa de más arriba, que es, sea del tipo que sea, sumamente difícil conseguirla sin puntos débiles y sin grietas. En efecto, mientras cabe la posibilidad de que esté impregnada de jugo y húmeda, por la acción del sol y los vientos sucede que se seca por la parte de arriba; por ese motivo, como vemos que pasa en el caso de los restos de aluvión, la superficie se contrae con el barro y abre grietas que no es posible cerrar. En efecto, aquellas partes que se hubieren desecado no se vuelven a unir por ninguna clase de procedimiento; las partes húmedas, por el contrario, ceden a las que tiran con facilidad de ellas y siguen su camino.

Observo que los antiguos han construido la capa externa preferentemente de tierra cocida o de piedra. En efecto, he visto que, sobre todo donde no fuera posible pisar, se colocaron tejas de un codo de nacho por todos sus lados, fijadas con cal mezclada con aceite. y se ven con frecuencia ladrillitos pequeños, de un dedo de espesor y dos dedos de acho, el doble de largos que de anchos, unidos lateralmente a imitación de las espigas. Es posible ver por todas partes capas exteriores de piedra, hechas con lastras de mármol bastante grandes y también de trozos más pequeños y de teselitas. Se ven además pisos antiguos que constan de un único material, hecho con cal, arena y tierra cocida en polvo, en lo que puedo adivinar, a partes iguales. Estoy seguro de que estos firmes serán más sólidos e inalterable, si añadieres una cuarta parte de toba tiburtina en polvo. Hay quienes, para este tipo de obra, prefieren sobre todo el polvo de la puzolana que llaman 'lapilli'. Asimismo, podemos comprobar que las capas externas obtenidas a partir de un único material,
[1] Vitruvio-Polion, Marco. De Architectura (c15 a.C.). Ortiz y Sanz, J oseph (trad.). Madrid: Imprenta Real, 1787.

[2] Alberti, Leon-Battista. De Re Aedificatoria (1452). Madrid: Ediciones Akal, 1992. p. 86. 
con un apisonado bastante frecuente y repetido a lo largo de días, adquiere una consistencia y una dureza casi superior a la de la piedra. $Y$ es un hecho cierto que, en este tipo de pisos, si se los riega con agua de cal, si se los unta con aceite de linaza, se consigue una dureza como vitrea e inatacable por los agentes atmosféricos. Aseguran que la cal amasada con aceite no permite que ningún elemento dañino afecte a los pavimentos.

Bajo el piso observo que se extiende un material hecho con cal y pequeños fragmentos de tierra cocida despedazada, con un espesor de dos o tres dedos. Bajo él se encuentra una especie como de relleno hechos en parte con tierra cocida despedazada, en parte con pequeños fragmentos de piedras que los canteros han hecho saltar con el cincel. y esta capa tiene aproximadamente un pie de espesor: en otros lugares encuentro que, entre esta capa y la superior, se han dispuesto ladrillitos de tierra cocida. por último, en la parte más profunda, se asientan unas piedras no más grandes que el tamaño de un puño. Se puede observar que las rocas que se encuentran en las corrientes de agua, rocas que reciben el nombre de 'masculinas', como es el caso de las esféricas, las silíceas y las vitreas, se secan en cuanto se las saca del agua; en cambio, la tierra cocida, la toba,... mantienen durante largo tiempo la humedad que han absorbido. Por ello hay quienes aseguran que de ningún modo penetra la humedad procedente de la tierra en las capas superiores, siempre que el pavimento haya sido asentado sobre esta clase de roca. Hemos visto también que hubo quienes emplearon tejas de tierra cocida sobre pequeños pilares de pie y medio dispuestos sobre el suelo en hiladas cuadradas cada dos pies, tejas sobre las que levantaron el pavimento como hemos dicho. Pero este tipo de pavimento se utiliza sobre todo para las termas, de las que se hablará en el lugar correspondiente.

Los pavimentos se complacen con el agua y el ambiente húmedo durante su construcción, y se conservan más sólidos e intactos en terreno umbroso y húmedo. Y entre los elementos más perjudiciales para los pavimentos se encuentran la poca consistencia del terreno y la desecación brusca. En efecto, así como la tierra se hace compacta en los campos de labor a causa de las lluvias repetidas, del mismo modo también los pavimentos regados generosamente adquieren una consistencia férrea y monolítica.

En el lugar en que cae el agua de lluvia procedente de los canalones de los tejados, hay que disponer una capa exterior de piedra sumamente sólida y compacta, con el fin de evitar que, por efecto de la continua, por así decir, maldad de las gotas en su caída se agujeree y se dañe.

Además, hay que tener cuidado con el pavimento que se asienta sobre un entarimado de madera, para que la osatura que lo sustenta sea robusta y proporcionada en sus componentes; si esto no es así, si por ejemplo una pared o una viga es excesivamente más sólida que las demás por algún sitio, por ese lugar se resquebrajará y sufrirá daño el pavimento» [3].

En el «Capítulo IV» del Libro IX: La ornamentación de los edificios, dice:

«No hay que dejar pasar algunos elementos ornamentales que puedes aplicar a los edificios privados. Los antiguos pintaban sobre el pavimento de pórfido laberintos cuadrados y redondos, para que en ellos hicieran 
ejercicios los niños. Hemos visto superficies pintadas con enredaderas de ramas ondulantes ampliamente esparcidas; se ven también algunos que representaron alfombras extendidas en los dormitorios mediante mosaico marmóreo; otros regaron el pavimento de guirnaldas y ramilletes. Alabaron el hallazgo de aquel famoso Oso, que hizo en Pérgamo un pavimento, en el que aparecían representados los restos esparcidos de una comida: obra, ¡Dios me asista!, en absoluto inadecuada para un comedor. Creo que Agripa actuó de la manera más apropiada, al haber realizado una pavimentación con cascotes de arcilla.

Odio la suntuosidad. Me agrada aquello que, fruto de la inteligencia, contribuye a la belleza y al buen gusto» [4].

Andrea Palladio (1508-1580), en el «CAPÍTULO XXII. De los pavimentos y sofitos de los altos» del primer libro de Quattro libri dell'architettura (1570), dice:

«Habiendo ya visto la forma de lonjas o galerías, la de las salas y la de las piezas menores, conviene tratar de los pavimentos y sofitos. Los pavimentos se suelen hacer o de terrado (terrazzo) como se usa en Venecia [5], o de ladrillo o de losa. Son excelentes los terrazzos hechos de (fragmentos de) teja o de ladrillo machacado, o de guijo menudo y cal de piedras rodadas de los ríos, o de piedra de Padua, estando bien batidos. Se deben estos hacer en primavera o en el estío para que puedan secarse bien. Los pavimentos de ladrillo, como se pueden hacer de varias figuras y colores según la variedad de las gredas, saldrán muy hermosos a la vista por los colores referidos. De piedra o losa se hacen pocas veces en las viviendas, porque el invierno son muy fríos: pero en galerías y lonjas están muy decentes.

Adviértase que todas las piezas estén a un piso, de manera que los umbrales inferiores de las puertas no resalten sobre el pavimento. Aun si el de algún retrete o pieza pequeña no llegare con su altura a igualar el resto, se le debe hacer encima un sobrado o falso techo» [6].

En el «CAPÍTULO X. De las salas Egipcias. Lámina XXIX» del segundo libro de Quattro libri dell'architettura, dice:

«Estos salones eran semejantes a las basilicas (las cuales eran edificios destinados a los negocios públicos, y de que trataremos cuando describamos los foros); puesto que en tales salones se hacía un pórtico, cuyas columnas distaban de las paredes al modo que en las basílicas, y sobre las columnas mismas había cornisón entero. El espacio desde las paredes a las columnas llevaba pavimento al descubierto, y formaba un andito en redededor con petril» [7].

En el «CAPÍTULO XIII. De la distribución de las casas de campo» del segundo libro de Quattro libri dell'architettura, dice:

«Los graneros deben tomar luz de norte para que no se recalienten los granos, sino que refrescados con el aire septentrional se conserven largo tiempo, y no críen gorgojo. Su pavimento debe ser de terrado si se puede, y si no, de tablaje,; pues la obra de cal corrompe el trigo» [8].

Gottfried Semper (1803-1879), en su libro Los cuatro elementos de la construcción [9], enuncia lo que para él son los elementos básicos de la arquitectura: el
[3] Alberti, Leon-Battista. De Re Aedificatoria (1452). Madrid: Ediciones Akal, 1992. pp. 161-163.

[4] Ibíd. p. 379.

[5] Terrado o terrazo es en Italia un suelo al descubierto en lo superior de las casas en vez de tejado. Nosotros lo llamamos azoteas. El casería de Nápoles no tiene otro techado, y con tan poco declive que apenas se conoce. Sin embargo, no se ven gotera, por la calidad del material que para ello tienen, el cual es una argamasa compuesta de mortero líquido y fragmentos menudos de pómez que arroja el monte Vesuvio en sus incendios y erupciones, llamado allí rapillo. Como el pómez es tan ligero y no admite humedad alguna, resulta que aunque el solado de estos terrados sea muy grueso no agrava el maderage ni las paredes; y aunque sea delgado no cala el agua de las lluvias. Cuando demuelen alguna casa, lo primero que hacen es arrancar el solado en costras muy grandes, y guardarlas para sentarlas en la obra nueva, soldándolas con el material mismo.

[6] Palladio, Andrea. Quattro libri dell'architettura. Venecia, 1570.

[7] Ibíd.

[8] Ibíd.

[9] Armesto-Aira, Antonio (ed.) y García-Roig, Marta (trad.). Escritos fundamentales de Gottfried Semper. El fuego y su protección. Barcelona: Fundación Arquia-Caja de Arquitectos, 2014. 
hogar — que es el elemento central—, el cerramiento, la cubierta y el suelo. Para Semper, el suelo es el encargado de proteger el hogar, resguardándolo de inundaciones.

$Y$ ya en el siglo $X X$, algunos autores se han servido de sus experiencias japonesas, bien por su origen o bien como consecuencia de algún viaje, para desarrollar una teoría del suelo en oriente. Es el caso de de Bruno Taut (1880-1938) plasmadas en el libro La casa y la vida japonesas (Das japanische Haus und sein Leben (1933) [10] o de Arata Isozaki (1931-) en el artículo «Floor and internal Spaces in Japanese Vernacular Architecture: Phenomenology of Floors» (1986) [11].

En 1959, MIT Press publica el libro Experiencing Architecture [12] de Steen Eiler Rasmussen (1898-1990) donde el autor perfila algunos aspectos sobre la condición fenomenológica del pavimento:

"Las impresiones de dureza y de blandura, de pesadez y de ligereza, están íntimamente relacionadas con el carácter de la superficie de los materiales. Hay innumerables tipos de estas superficies, desde las más bastas hasta las más afinadas. Si se clasificaran los materiales de la construcción según su grado de aspereza, habría un buen número de ellos que ofrecerian diferencias imperceptibles. A un extremo de la escala se hallarían la madera en bruto y los pequeños guijarros, y en el otro la piedra pulida y las superficies lisas y barnizadas. Puede que no resulte sorprendente que tales diferencias se puedan apreciar a simple vista, pero hemos de destacar que sin haber tocado los materiales conocemos ya con seguridad la diferencia que media entre materiales tales como la arcilla cocida, la piedra cristalina y el hormigón.

En Dinamarca, actualmente, las aceras aparecen pavimentadas con varias hileras de losetas de hormigón, separadas entre sí por hileras de adoquines de granito. Sin duda este sistema de pavimentación resulta práctico a la hora de levantar las losetas (poder descansar la palanca sobre el duro granito, que no se parte con facilidad). Pero la combinación de estos dos materiales da como resultado una superficie notablemente desigual. El granito y el hormigón no son fáciles de combinar; incluso la suela del zapato nota lo desagradable que resulta tal combinación, al presentar ambos materiales distintos grados de dureza. Y cuando - como suele ocurrir a veces- este pavimento está además flanqueado por anchas fajas de asfalto o de grava, y encintado a su vez con piedra, la moderna acera danesa se convierte en verdadero muestrario de materiales de pavimentación, que no se puede comparar ni remotamente con los pavimentos de otros períodos, que son agradables para la vista y confortables para el pie. El londinense llama 'pavimento' a su acera, y un ejemplo de un pavimento más fino que el de Londres difícilmente se puede encontrar.

En Suiza el adoquinado es demasiado bello, como puede verse en las fotografías de una tranquila plazuela de Fribrugo, donde el pavimento bien dispuesto procura a la vista un placer estético, con el juego del color amarillento de la piedra caliza de la fuente y los muros que le rodean. Gran variedad de materiales puede ser utilizada como pavimento con resultados muy satisfactorios, pero estos materiales no pueden ser combinados o utilizados de manera arbitraria. En Holanda se utiliza el clinker para calles y autopistas, lo que procura una superficie esmerada y agra- 
dable. Pero cuando se utiliza el mismo material como base para pilares de granito como en Stormgade (Copenhague), el reseultado dista mucho de ser bueno: no sólo resulta que el clinker se astilla, sino que también se tiene la impresión de que los pesados pilares se van hundiendo poco a poco en el blando material» [13].

En el año 2014, Rem Koolhaas (1944-) fue elegido Director de la XIV Bienalle di Venecia con el tema Fundamentals, que constaba con tres exposiciones, de algún modo, entrelazadas: Monditalia, Absorbing Modernity: 1914-2014 y Elements of Architecture. En esta última, junto con sus alumnos de la Harvard Graduate School of Design, y según sus propias palabras, se analiza con un microscopio los fundamentos más básicos en el diseño y construcción de la arquitectura, y que han sido empleados a lo largo de la historia en todos los lugares del mundo: the wall, the ceiling, the roof, the door, the window, the façade, the balcony, teh corridor, the fireplace, the toilet, the stair, the escalator, the elevator, the ramp y the floor — que de forma lógica aparece el primero de su lista. De algún modo, se analiza la arquitectura desde el fragmento.

Fruto de esa exposición, se elabora el Catálogo de la Exposición: Elements of Architecture (2014) [14] editado por la editorial Marsilio y formado por 15 cuadernillos, cada uno de ellos dedicado a un elemento, que incluye un pequeño ensayo acompañado de algunas imágenes. Unos años después, la editorial Taschen lo publica en un solo volumen.

Como un proyecto de investigación paralelo con el tema de la XIV Bienalle, la arquitecta e investigadora veneciana Giulia Foscari publica el libro Elements of Venice [15] —con prólogo de Rem Koolhaas-que analiza específicamente doce de los quince elementos estudiados a nivel global en la exposición general, pero referidos a la ciudad de Venecia. Y entre ellos, incluye el 'suelo', al que dedica un breve ensayo, acompañado de algunas imágenes.

Unos años antes, en 1990, el académico y catedrático de la Universidad Politécnica de Madrid, Luis Fernández-Galiano (1950-) fue el comisario de la exposición 'El espacio privado. Cinco siglos en veinte palabras' que se editó en forma de catálogo con el mismo nombre [16] y aunque no incluía en su lista el elemento 'suelo', si exploraba el estudio de la arquitectura desde el fragmento. Todos ellos, ilustrados con imágenes de origen transversal, como pinturas o fotografías.

Y en el año 2014, animado por el tema de la XIV Bienalle y para celebrar los 400 números, Fernández-Galiano publica un número monográfico de la revista Arquitectura Viva, firmado por él, con el título Elements [17] donde analiza 32 elementos de forma emparejada, entre ellos: suelo/techo.

«Hay un discurso técnico del suelo que tiene que ver con su condición de piso o forjado: bandeja horizontal estructural, sometida a esfuerzos de flexión, y alternativa por tanto a la bóveda pétrea; como extensión del dintel, lleva a su extremo la gramática de la construcción arquitrabada. Pero hay otro discurso funcional, estético y simbólico que alude a su naturaleza de superficie pisable: su condición de pavimento en cuyo diseño interviene una multitud de variables.

Muy importantes son, desde luego, las geométricas. Si está compuesto de partes, su despiece es con frecuencia una radiografía de la lógica compositiva y la lógica constructiva del edificio: hay pavimentos que son
[10] Taut, Bruno. La casa y la vida japonesas. Barcelona: Fundación Arquia-Caja de Arquitectos, 2007. Colección Arquia/ temas, número 19.

[11] Isozaki, Arata. «Floors and Internal Spaces in J apanese Vernacular Architecture: Phenomenology of Floors». RES: Anthropology and aesthetics. New York: Peabody Museum of Archeology and Ethnology, Harvard University, spring 1986, vol. 11, pp. 54-77.

[12] Rasmussen, Steen-Eiler. Experiencing Architecture. Cambridge, Massachusetts: MIT Press, 1959. Rasmussen, Steen-Eiler. Experiencia de la arquitectura. Barcelona: Editorial Labor, 1974.

[13] Ibíd. pp. 27-32.

[14] Koolhaas, Rem (ed.). Elements of architecture. The Venice Biennale. 14th International Architecture Exhibition. Venezia: Marsilio Editori, 2014.

[15] Foscari, Giulia. Elements of Venice. Zürich: Lars Müller Publishers, 2014.

[16] Fernández-Galiano, Luis (com.). El espacio privado. Cinco siglos en veinte palabras. Madrid: Ministerio de Cultura y Dirección General de Bellas Artes y Archivos, 1990.

[17] Fernández-Galiano, Luis. «Treinta y dos elementos. Architecture, from System to Fragment». Arquitectura Viva.

Elements/Elementos. Madrid: Editorial Arquitectura Viva, diciembre 2014, núm. 169, pp. 11-60. 
arquitecturas abreviadas. Su color y su trazado, su textura y su comportamiento ante la luz son muchas veces determinantes en la experiencia perceptiva del espacio arquitectónico, al ser tan dominante su presencia en el campo visual. Su ceder ante la pisada; fundamental en la experiencia háptica. Su comportamiento acústico, absorbente o reflectante; básico en la experiencia sonora de la arquitectura. El suelo y sus ropajes modelan el oído, el tacto y la mirada.

La percepción antropológica del suelo la expresan bien los poetas, como Miguel Hernández que añora en la ciudad su pisada campesina: «lba mi pie sin tierra, iqué tormento!, / vacilando en la cera de los pisos... / ¡Asfalto!: qué impiedad para mi planta! / ¡Ay, qué de menos echa / el tacto de mi pie mundos de arcilla...»

o el Salinas que remita a la tierra firme del hombre: "Suelo. Nada más. / Suelo. Nada menos. / Y que te baste con eso»

Al fin, ese pavimento hollado y firme, sólido y tenaz, símbolo arquetípico de soporte y sustento, acaba aludiendo al pueblo llano cuyo trabajo sostiene las ficciones de la arquitectura. Eso ya lo sabía el Honorio que en el siglo XII construía su iglesia metafórica: «Pavimentum, quod pedibus calcatur, est vulgus cujus labore Ecclesia sustentatun» [18].

E mismo autor, en el número titulado Casa, Cuerpo y Crisis (2003) [19] de la revista AV Monografías se propondría poner en orden una constelación de cientos de imágenes.

El breve texto de Rem Koolhaas —en colaboración con sus alumnos de Harvard-y el apéndice veneciano de Giulia Foscari, han sido una fuente que han permitido explorar nuevos caminos en esta tesis doctoral. $Y$ algunos de los ejemplos que en esos cortos ensayos se citaban, se han desarrollado aquí de forma más extensa desde un punto de vista crítico.

Si bien la querencia natural de Rem Koolhaas por la política y por la economía globales, a veces le hacía derivar sus investigaciones sobre el suelo a lugares

[18] Fernández-Galiano, Luis. «Treinta y dos elementos. Architecture, from System to FragmentSuelo. Del piso al pavimento. Floor. From Slab to Pavement». Arquitectura Viva.

Elements/Elementos. Madrid: Editorial Arquitectura Viva, diciembre 2014, núm. 169, p. 28.

[19] Fernández-Galiano, Luis. AV Monografías. Casa, Cuerpo y Crisis. House, Body, Crisis. Madrid: Editorial Arquitectura Viva, julio, 2003, núm. 104.

[20] Koolhaas, Rem. Delirious New York. New York: Oxford University Press, 1978. ISBN: 9780195-2003-5.

Koolhaas, Rem. Delirio de Nueva York. Barcelona: Editorial Gustavo Gili, 2004. ISBN: 978-842-5219665.

[21] Moro, J osé-Luis. Flooring. Volume 1.

Standars. Solution principles. Materials. Berlín:

DETAIL Practice Book e Institut für internationale Architektur-Dokumentation GmbH \& Co. KG,

2016.

[22] Moro, J osé-Luis. Flooring. Volume 2. Design. Life cycle. Case Studies. Berlín: DETAIL Practice Book e Institut für internationale Architektur-

Dokumentation GmbH \& Co. KG, 2016. hacia donde este trabajo de investigación no le interesaba posar su mirada. Del mismo modo, en su ensayo, se interesa por el suelo como 'forjado' o como 'placa estructural' - seguramente como consecuencia del estudio de los rascacielos en su libro Delirious New York (1978) [20]. Así, el suelo como forjado tampoco ha sido objeto prioritario de esta tesis, si bien en algún caso concreto sí ha podido incorporarse a los análisis desarrollados.

Tampoco este trabajo de investigación se ha centrado en los aspectos técnicos, normativos o en las innovaciones constructivas de los pavimentos, por considerar que hay manuales específicos y publicaciones periódicas que se encargan de esos aspectos donde la teoría de la arquitectura se enfrenta con aspectos de la física, de la química o de la mecánica de materiales. Es el caso de los dos cuadernos Flooring 1 [21] y Flooring 2 [22] publicados por José Luis Moro, Catedrático de Construción del Institute for Design and Construction de la University of Stuttgart en Alemania para la editorial Detail. 
Pavimentos: huellas fenomenológicas, registros arqueológicos y planos de referencia 


\section{Método. Atlas. Constelaciones e intersecciones}

La arquitectura, como cualquier otra disciplina, tiene una larga tradición de desarrollar y transmitir las teorías mediante el uso de la palabra a través del escrito, pero el arquitecto es un ser ávido de imágenes. Si bien es cierto que Robert Le Ricolais (1894-1977) nos recuerda [1] una cierta desconfianza sobre la verdad de las imágenes que percibimos: "Las cosas mismas mienten, y también sus imágenes».

La mitología griega sitúa al titán Atlas y a su hermano Prometeo, enfrentándose a los dioses del Olimpo para devolverles su poder a los hombres. También cuenta que el castigo fue semejante a su fuerza: un buitre arrancaba el hígado a Prometeo en los confines del Este, Atlas, en el Oeste —entre Marruecos y Andalucía, cerca del Estrecho de Gibraltar - fue obligado a sostener sobre sus hombros todo el peso de la bóveda celeste. Ese peso le hizo ser poseedor de una sabiduría infinita. Dio su nombre a una cordillera —el Atlas- y a un océano —el Atlántico-y, desde luego, a una forma arquitectónica antropomórfica —el atlante- que sirve como columna de soporte.

Un atlas de imágenes es una forma visual de conocimiento, un proceso abierto, receptivo a posibles ampliaciones, cuyo objetivo es ofrecer afinidades electivas —como decía J.W. Goethe-y relaciones no evidentes. Originalmente se trataba de un conjunto de mapas geográficos reunidos en un volumen, un libro de imágenes cuyo objetivo final es ofrecer, de manera más o menos sistemática, todo un bodegón de tipologías y tipos. El atlas, convertido en un género editorial y método científico a partir del siglo XVIII —-donde se pueden incluir los libros de láminas de la Encyclopèdie- se desarrolló con más intensidad durante el siglo XIX. Pero ha sido la popularización de la fotografía y la cultura de la imagen del siglo $X X$ los que han permitido que el género del Atlas de imágenes, no sólo se vinculara al ámbito científico, sino que también lo incorporaran los coleccionistas, públicos o privados.

«Un atlas no es un diccionario, ni un manual científico, ni un catálogo sistemático. Se trata de una colección e cosas singulares, en general harto heterogéneas, cuya afinidad produce un saber extraño e infinito (nunca cerrado): helechos o animales marinos, guisantes o arquitecturas industriales,... como en la 'Historia natural infinita' de Paul Klee, o en aquella enciclopedia china reinventada por Jorge Luis Borges que abre el libro de Mlchel Foucault 'Las Palabras y las Cosas'» [2].

En el ámbito de la biología encontramos atlas como los del naturalista y filósofo alemán Erns Haeckel (1834-1919), como por ejemplo Kunstformen der Natur (1899-1904) sobre animales marinos. También existen atlas en el ámbito de la antropología o la psicología como el Atlas del hombre criminal (L'uomo delinquente / El hombre delicuente) (1876) de Cesare Lombroso (1835-1909).

También la obra de algunos artistas se ha acercado al conocimiento mediante la exploración tipológica sobre un mismo tema, como la obra del matrimonio alemán Bernd Becher (1931-2007) y Hilla Becher (1934-2015), que exploró, durante cinco décadas, las construcciones industriales [3] y algunos elementos de la ingeniería civil, siendo fieles a la afirmación de Walter Gropius (1883-1969): «sólo el artista tiene la capacidad e darle un alma a un producto muerto como la máquina» [4]. La pareja, que formó la generación de fotógrafos más importante en el arte contemporáneo, como Walker Evans (1903-1975), Henri CartierBresson (1908-2004) o Robert Frank (1924-), se conoce en la Academia de Arte
[1] J uárez-Chicote, Antonio. «A propósito de Robert Le Ricolais». Arquitectos. Madrid: Consejo Superior de Arquitectos de España, 1996, vol. 96/3, núm. 141, pp. 72-76. ISSN: 0214-1124.

[2] Didi-huberman, George. Atlas. ¿Cómo llevar el mundo a cuestas?. Madrid: Museo Nacional Centro de Arte Reina Sofía y TF Editores, 2010. p. 284

[3] Para comprender el interés sobre la temática industrial en la década de 1960, habría que recordar que Andy Warhol llamaba a su estudio: la Factory.

[4] Armin, Zweite (falta el capítulo). En: Becher, Bernd y Becher, Hilla. Tipologías. Madrid: Fundación Telefónica, 2005 
en Düsseldorf y es ahí donde se interesan por los vestigios arqueológicos frente a la edad industrial [5]. Les interesaban las instalaciones industriales cerradas y amenazadas de demolición, es decir, convertidas en arqueología industrial. La pareja empezó a documentar fotográficamente esas estructuras en peligro de extinción.

En su primer proyecto, Fachwekrhäuser —Framework Houses_ (1959-1973) fotografiaron los testeros o hastiales de las casas populares construidas con estructura de madera vista. Todas las fotografías eran tomadas desde un punto de vista parecido, estableciendo cierta familiaridad, pero subrayando sus leves variaciones. También lo hicieron con depósitos de agua, torres de refrigeración, silos de cereal, gasómetros, graveras, naves industriales, castilletes de extracción, altos hornos,... Por lo tanto, en su trabajo se preocuparon mucho de acotar los límites de su obra, tanto en el ámbito geográfico, en la técnica elegida, así como en el ámbito temático de sus intereses.

La metodología, que tenía algo de clasificación entomológica, insistía en poner en valor la igualdad y la diferencia, pero también reflexionaba sobre los conceptos de unidad y de diversidad. Desde un punto de vista epistemológico, su obra invita al observador a poner en valor las coincidencias y las divergencias. Como si se tratara de la mirada sistemática de un científico que se propone comprender el mundo recorriendo lugares significativos de un territorio interesándose en una especie animal o vegetal, Bernd e Hilla proponían los objetos fotografiables, estableciendo pautas de comportamiento en la atmósfera geográfica donde se situaban y detectando rasgos comunes. La repetición aparente, y la ausencia de color, situaban a esas composiciones cerca del arte mecanizado del pop-art [6], como si fueran infinitos ensayos sobre un mismo tema.

La forma de presentar sus fotografías tenía implícito el carácter tipológico y les llevaba a no ofrecer objetos unitarios, sino grupos, tipologías o familias, siempre de forma reticular. Es decir, se puede considerar que ha existido una voluntad por documentar gráficamente su taxonomía, tanto en el ámbito del orden de las cosas -y ahí entra la arquitectura-, de la naturaleza y del hombre.

Como género editorial, los Atlas inicialmente recopilaban imágenes de un mismo campo de conocimiento, pero esto fue mutando - sobre todo por la aparición de los coleccionistas de imágenes como Aby Moritz Warburg (18661929) - que incorporaban imágenes de origen transversal. El historiador elaboró entre 1924 y 1929 el Atlas Mnemosyne (Bilderatlas): una obra inconclusa cuyo método incidía en una investigación heurística sobre la memoria y las imágenes. En ella, el autor realizó un acopio de fotografías, recortes y detalles, dispuestos sobre paneles con el fondo oscuro en forma de collage, donde el azar y la intención convivían de forma simultánea, además de la elaboración de unos textos. La fotografía de cada panel constituía una de las láminas del Atlas Mnemosyne. La metodología permitía corregir la posición de algunas imágenes, su eliminación o la incorporación de otras nuevas.

Su metodología nacía de una pulsión de archivo compulsiva y de la obsesión personal por el acopio, que todo coleccionista incorpora de forma natural en sus actos. Pero también de la depuración, de la selección y de la generosa difusión. Detrás de todo buen Atlas se esconde un equilibrio entre las obsesiones privadas y las necesidades colectivas, de tal modo, que el autor debe ofrecer a los demás la información filtrada, estructurada y sistematizada. Y es que el trabajo de Warburg es, de algún modo, dionisiaco, ya que está relacionado con el deseo más primario, con una pulsión, casi con un mal [7]. 
«Aun cuando el atlas 'Mnemosyne' constituye una parte importante de nuestra herencia — herencia estética, ya que inventa una forma, una manera nueva de disponer las imágenes entre sí; herencia epistémica, pues inaugura un nuevo género del saber- [...] El Atlas warburgiano es un objeto pensado a partir de una apuesta. Apostar que las imágenes, agrupadas de cierta manera ofrecerían la posibilidad —o mejor, el recurso inagotable — de una relectura del mundo» [8].

En 1962, el artista Gerhard Richter comienza una colección de fotografías vinculada estrechamente con su investigación artística. «El atlas es [...] el palimpsesto del inconsciente (individual y colectivo), que sustenta y tiende a dominar la obra pictórica» [9].

Primero, estaba formado por los modelos iconográficos de sus pinturas, unos Fotobilder (1962-1964) que confeccionaron los primeros paneles de su álbum. Con el aumento de su colección de fotografías — alrededor de 5.000- desaparece la relación directa con su trabajo y el Atlas empieza a considerarse como una obra autónoma. El Atlas está formado por fotografías encontradas o realizadas por el artista, recortes de prensa, collages, dibujos, ejercicios experimentales,... El material está ordenado siguiendo dos pautas: la primera vinculada con el tema del documento, y la segunda sigue un criterio formal —dimensión y forma- [10].

La tesis doctoral propone el análisis crítico y teórico de los pavimentos de algunas obras de arquitectura ilustradas con imágenes, planos y fotografías relativas a cada ejemplo. Pero además de esas imágenes específicas, una constelación de imágenes — de origen transversal e interdisciplinar- acompañará a cada caso de estudio estableciendo relaciones directas e invisibles, miméticas y antitéticas, evidentes y no explícitas. Estas imágenes, formarán unas láminas o planchas, que a modo de álbum se insertarán entre las páginas del texto, y cuya acumulación, finalmente construirá un Atlas de pavimentos, una memoria crítica visual, un glosario que sirva de guía a quien decida hoy proyectar y construir arquitectura contemporánea.
[5] Pérez-Gallardo, Helena y Sougez, Marie-Loup. Diccionario de historia de la fotografía. Madrid: Editorial Cátedra, 2003.

[6] «Mientras el pop-art integraba la iconografía banal de la sociedad de consumo en el arte, el arte minimalista se servía de materiales prefabricados industrialmente y trasladaba a la abstracción el principio de producción divisorio del trabajo en cadena».

Marzona, Daniel. Arte minimalista. Colonia (Alemania): Taschen Benedikt, 2009.

[7] Didi-huberman, George. Atlas. ¿Cómo llevar el mundo a cuestas?. Madrid: Museo Nacional Centro de Arte Reina Sofía y TF Editores, 2010. p. 8.

[8] Ibíd. p. 19.

[9] Chevrier, Jean-Francois. «Entre las Bellas Artes y los media (el ejemplo alemán: Gerhard Richter)». En: Fotografía y Pintura en la obra de Gerhard Richter. Barcelona: MACBA, 1999. p. 184.

[10] Giaveri, Francesco. «El Atlas de Gerhard Richter». Anales de Historia de Arte. Madrid: Universidad Complutense de Madrid, 2011, volumen extraordinario: Saberes artísticos bajo signo y designios del «Urbinate», pp. 225-239. [http:// dx.doi.org/ 10.5209/rev_ANHA.2011.37459 ] $(21 / 05 / 2016)$ 
Pavimentos: huellas fenomenológicas, registros arqueológicos y planos de referencia 


\section{Fuentes}

Debido al elevado número de imágenes y planos que se presentan en esta tesis, se han consultado fuentes directas. Todas las imágenes hacen referencia al archivo al que pertenecen y, si es posible, al número de identificación dentro de cada archivo. Aquí se detallan algunos de los archivos consultados más importantes:

Andy Warhol Foundation for the Visual Arts. New York, EEUU. Archivio Carlo Scarpa.

Archivo Amancio Williams. Argentina.

Archivo de Gio Ponti. Milán, Italia.

Archivo de la Familia García de Paredes. Madrid, España.

Archivo familia Fernando Cassinello. Madrid, España.

Archivo Fundación Aldo y Hannie van Eyck.

Archivo personal del autor JFGS. Almeria-Madrid, España.

Associazione Archivio Storico Olivetti. Ivrera, Italia

Bayerische StaatsBibliothek. Munich, Alemania.

Benaki Museum. Modern Greek Architecture Archives. Atenas, Grecia.

Betty Krulik Fine Art. New York, EEUU.

Bibliothèque Kandinsky. París, Francia.

Bibliothèque Nationale de France. París, Francia.

Bildarchiv Foto Marburg. Deutsches Dokumentaionszentrum für Kunstgeschichte.

BNE. Biblioteca Nacional de España. Madrid, España.

CAC. Centro Andaluz de Arte Contemporáneo. Sevilla, España.

Cambi Casa D'Aste. Génova y Milano, Italia.

CCA. Canadian Centre for Architecture. Montreal, Canadá.

Center for Creative Photography. Tucson, Arizona,EEUU.

Centre Georges Pompidou. París, Francia.

Centre Pompidou. Málaga, España.

Centro del Patrimonio Etnológico. Madrid, España.

Comune Venezia. Venecia, Italia.

Conjunto Arqueológico de Itálica. Consejería de Cultura y Patrimonio Histórico.

Junta de Andalucía. Sevilla, España.

Danish National Art Library. Köbenhavn, Dinamarca.

Digitalt Museum. Art Council Norway. Noruega.

DOMUS Archivo. Milán, Italia.

Europeana Collections.

Fondation Le Corbusier. París, Francia.

Fondazione Musei Civici di Venezia. Italia.

Fondazione Querini Stampalia. Venecia, Italia.

Fundación Alejandro de la Sota. Madrid, España.

Fundación Almine y Bernard Ruiz-Picasso para el Arte. Bruselas, Bélgica.

Madrid, España.

Fundación archivo Aldo y Hannie van Eyck. Holanda.

Fundación Lázaro Galdeano. Madrid, España.

Galleria Nazionale delle Marche. Palazzo Ducale di Urbino. Italia.

Gallerie Dell'Accademia di Venezia. Italia.

Geheugen van Nederlan.

Gemäldegalerie Alte Meister. Dresden, Alemania.

Gemäldegalerie der Staatlichen Museum zu Berlin, Alemania.

Getty Images. Los Ángeles, EEUU.

Harvard Art Museums. Fogg Museum. Busch-Reisinger Museum. Arthur M. Sackler Museum. Cambridge, EEUU. 
Harvard Library. Harvard Map Collection. Cambridge, EEUU. IMA. Indianapolis Museum of Art. Indianápolis, EEUU.

INHA. Instituto National d'Histoire de l'Art. Paris, Francia.

Instituto Eduardo Torroja de Ciencias de la Construcción, CSIC. Madrid, España.

Instituto per la Storia del Risorgimento Italiano. Roma, Italia.

Kunsthaus Zürich. Zurich, Almeania.

Liechtenstein. The Princely Collections. Viena, Austria.

LIFE. New York, EEUU.

Los Angeles Country Museum of Art. Los Ángeles, EEUU.

Magnum Photos. New York, EEUU.

MAK. Austrian Museum of Applied Arts / Contemporany Art. Vienna.

MAXXI. Museo Nazionale delle arti del XXI. Roma, Italia.

MET. The Metropolitan Museum of Art. New York, EEUU.

Minneapolis Institute of Art. Minnesota, EEUU.

MNCARS. Museo Nacional Centro de Arte Reina Sofía. Madrid, España.

MoMA. Museo de Arte Moderno de New York, EEUU.

MSK. Museum voor Schone Kunsten Gent. Gante, Bélgica.

Musée des Beaux-Arts de Caen. Francia.

Musée du Louvre. París, Francia.

Musei Vaticani. Roma, Italia.

Museo Carmen Thyssen de Málaga, España.

Museo de Bellas Artes de Asturias, España.

Museo Nacional de Artes Decorativas de Madrid, España.

Museo Nacional del Prado. Madrid, España.

Museo Nacional del Traje. Madrid, España.

Museo Nacional Thyssen-Bornemisza de Madrid, España.

Museo Pablo Picasso de Málaga, España.

Museum of Ravenna. Rávena, Italia.

NASA. EEUU.

National Galleries Scothland. Edinburgh, Escocia, Reino Unido.

National Gallery of Art. Washington, EEUU.

Navone Associati. Milan, Italia.

Nederlands Foto Museum. Rotterdam, Países Bajos.

Palazzo Barberini. Gallerie Corsini Nazionali. Roma, Italia.

Parco Archeologico di Paestum. Salerno, Italia.

Patrimonio Nacional. Colecciones Reales. Madrid. España.

Paul Rudolph Heritage Foundation. New York, EEUU.

Peggy Guggenheim Collection. Venecia, Italia.

Pinacoteca di Brera. Milán, Italia.

Procuratoria di San Marco di Venezia. Italia.

Real Academia de Bellas Artes de San Fernando. Madrid, España.

Real Sitio de San Lorenzo de El Escorial. España.

RIBA Collections. Architectural Press Archive. Londres, Reino Unido.

Rijksmuseum. The Museum of the Netherlands. Amsterdam, Países Bajos.

Royal Collection Trust. The Royal Archives. Windsor, Reino Unido.

TATE. Londres, Reino Unido.

The Bernard Rudofsky Estate. Viena, Austria.

The British Museum. Londres, Reino Unido.

The Easton Foundation. New York, EEUU.

The Israel Museum. Jerusalem, Israel.

The Josef and Anni Albers Foundation.

The Judith Rothschild Foundation. Washington, EEUU.

The Library of Congress. Washington, EEUU.

The Menil Collection. Houston, EEUU. 
The National Gallery. Londres, Reino Unido.

The New York Public Library. Digital Collections. New York, EEUU.

The Obama Presidential Library. Chicago, EEUU.

The State Hermitage Museum. San Petesburgo, Rusia.

The Utzon Archives. Aalborg, Dinamarca.

The Wallace Collection. Londres, Reino Unido.

The Walters Art Museum. Baltimore, Meryland, EEUU.

The William Hood Dunwoody Fund. Pensilvania, EEUU.

Universidad de Granada. España.

Universidad Politécnica de Madrid. España.

Universitäts Düsseldorf. Alemania.

University of Michigan. EEUU.

University of Toronto. EEUU.

Victoria \& Albert Museum. Londres, Reino Unido.

Victoria and Albert Museum. London, Reino Unido.

Warburg Institute Archive. Londres, Reino Unido.

White House Archives. Washington, EEUU

Worcester Art Museum. EEUU.

Yancey Richardson Gallery, New York.

Zentrum Paul Klee. Bern, Suiza. 
Pavimentos: huellas fenomenológicas, registros arqueológicos y planos de referencia 


\section{Organización y estructura del índice}

La tesis se organiza en dos grandes bloques.

En el BLOQUE I: Referentes se presentan unos capítulos referidos a conceptos que desarrollan aspectos específicos de la disciplina arquitectónica referidos al pavimento, pero también indagan en otros que de forma transversal se sitúan al margen de la disciplina, pero que hacen comprensible nuestra relación con el suelo pavimentado. Se describen ejemplos vinculados al espacio pictórico, al arte contemporáneo, a la literatura o al cine, referidos a distintas épocas.

Así, además del capítulo «Introducción. Suelos y pavimentos», el resto se titulan así: «El suelo cósmico. El pavimento y la escala», «El pavimento en la representación del espacio. Perspectiva central y movimiento», «El pie fenomenológico. El ojo a ras del suelo. Erotismo háptico», «El suelo habitado por el cuerpo. Arquitectura de contacto», «El suelo esponjoso. La densidad perdida», «Círculos de piedra. Huellas. Pavimentos en el paisaje. Eras de trilla y Artistas en el Paisaje», "El pavimento como soporte narrativo. El suelo parlante», «El pavimento inclinado. Anhelo natural» y «El pavimento textil. Alfombras y superposiciones».

En el capítulo «El suelo cósmico. El pavimento y la escala» se analiza el pavimento en relación a la diferentes escalas. Con el estudio del documental Power of Ten (1977) de los Eames y con los cuadros Pala Brera / Virgen con el Niño y Santos (c1465-1470) del pintor renacentista Piero della Francesca (1416-1492) y Traslación del cuerpo de San Marcos (1562-1566) de Jacopo Robusti Tintoretto (1515-1594) se llegan hasta ejemplos de El Partheon de Roma o la Unité d'Habitation de Marseille de Le Corbusier, o los pavimentos ligados a la infraestructura o el paisaje urbano.

En el capítulo «El pavimento en la representación del espacio. Perspectiva central y movimiento» se explica cómo el suelo es un elemento determinante en la percepción del espacio arquitectónico, debido a su dominio horizontal sobre el campo visual y a la alta proporción de superficie de los espacios que ocupa. Por tanto constituye un elemento esencial en el proceso creativo proyectual. La materialidad, el color, el trazado, el tamaño, el brillo o el patrón geométrico del pavimento contribuyen a impregnar la atmósfera de los espacios de un carácter específico diferente, según el caso. El pavimento puede acentuar algún aspecto de un espacio, ser un reflejo de su contrario el techo, establecer reglas de simpatía con algunos elementos estructurales, o comportarse como un elemento autónomo y endogámico.

En el capítulo «El pavimento fenomenológico. El ojo a ras del suelo. Erotismo háptico» se da cuenta del discurso fenomenológico que vincula al suelo y al pavimento donde la textura, la materialidad, la rugosidad, la temperatura, la topografía (el relieve), el sonido o su comportamiento ante la luz lo asocian generosamente a lo sensual, haciendo que el ojo pierda el monopolio de la emoción delegando en el tacto, el oído y el olfato. Además se analiza la relación del pie o del zapato con el plano pavimentado del suelo.

En el capítulo «El suelo habitado por el cuerpo. Arquitectura de contacto» se desarrolla nuestra relación más íntima con el plano del suelo pavimentado.

En el capítulo «El suelo esponjoso. La densidad perdida» se estudia la evolución histórica del suelo analizado desde la sección: desde los suelos huecos de 
las termas romanas, hasta los pavimentos formados por lápidas en las iglesias del Renacimiento o los suelos hinchables de Cedric Price (1934-2003). Y el estudio de la evolución en capas especializadas de la arquitectura contemporánea del siglo XX.

En el capítulo «Círculos de piedra. Huellas. Pavimentos en el paisaje. Eras de trilla y Artistas en el Paisaje» se da cuenta del origen de los pavimentos sobre el paisaje, primero como una necesidad agrícola, hasta las intervenciones de los artistas Land-art.

En el capítulo «El pavimento como soporte narrativo. El suelo parlante» se explica que el suelo también puede ser un soporte donde inscribir un contenido narrativo. Los ojos se deslizan sobre el plano pavimentado del suelo buscando una guía qué seguir. El suelo trazado de líneas esconde algunas reglas de juego, unos códigos y unas normas que, una vez conocidas, ofrecen una información imprescindible. Así ocurre en los campos de fútbol, en las canchas deportivas de baloncesto o de balonmano, en las pistas de atletismo o de tenis, en los cuadriláteros de boxeo o en los tatamis del judo. Pero también en las calles y en las carreteras, en los parkings, en los almacenes logísticos, en los helipuertos, o en las pistas de aterrizaje y plataformas de maniobras de los aviones en los aeropuertos. En todos los casos, un trazado misterioso y normalizado sobre el pavimento, establece y ordena unas pautas de comportamiento en esos lugares para el juego y para la circulación de vehículos, de objetos o de personas, que se obedecen disciplinadamente, sin necesidad de ser explicadas oralmente.

En el capítulo «El pavimento inclinado. Anhelo natural» y a partir del ejemplo de Stonehead, se analizan algunas obras de arquitectura donde el pavimento reviste un plano inclinado como la Capilla de Ronchamp de Le Corbusier.

Y finalmente, en el capítulo «El pavimento textil. Alfombras y superposiciones» dará cuenta de las posibilidades de las alfombras u otros elementos efímeros planos de establecer recintos y de fundar lugares.

En el BLOQUE II: Casos de estudio, que se divide en cinco capítulos, se desarrollan y analizan de forma más detallada algunos ejemplos de obras de arquitectura del siglo XX en las que el pavimento forma parte de su génesis. Los capítulos se titulan así: «El pavimento preciso. El suelo como plano de referencia», «El pavimento y el color. El suelo y la vida», «El pavimento en el umbral. Entre dos mundos», «El pavimento en Venecia. Metáforas acuosas» y «El pavimento y el fragmento. El tiempo y la memoria».

En el capítulo «El pavimento preciso. El suelo como plano de referencia» a partir del cuadro del cuadro El Cristo y la Adúltera (1546) de Tintoretto (1515-1594) y de la Città Ideale de Berlín (1495) de Francesco di Giorgio Martini (14391502) se establecerá un diálogo comparado con algunas obra de arquitectura de Mies van der Rohe (1886-1969). Y es que el pavimento que reviste el plano del suelo, de forma ineludible, se encuentra con el resto de elementos que construyen el espacio arquitectónico y paisajístico: columnas y pilares, muros y tapias, puertas y huecos, objetos y muebles, árboles y albercas, bordillos y límites,... Pero el suelo y sus trazas también se relacionan con elementos no contiguos como el techo, los dinteles, las cúpulas o las bóvedas. A veces, el trazado del suelo, termina por convertirse en un plano de referencia que da forma a los espacios, organiza la estructura, traza los tabiques y cerramientos, e incluso dicta la posición del ajuar doméstico. 
En este capítulo se analizarán la Casa Tugendhat (1928-1929) en Brno, la Casa para una pareja sin hijos (1931) en Berlín, la Casa Lemke (1932-1933) en Berín, la Casa 50x50 (1951-1952), la Casa Farnsworth (1946-1951) en Plano y el Pabellón de Barcelona (1928).

El capítulo «El pavimento y el color. El suelo y la vida» se introduce con el lienzo Las bodas de Caná (1562-1563) de Paolo Veronese (1528-158), pero también con las obras Vestidos simultáneos. Tres mujeres, formas, colores / Trois Femmes, formes, couleurs (1925) de Sonia Delaunay (1885-1979) o el Retrato de Adele Cloch-Bauer (1904-1907) de Gustav Klimt (1862-1918) donde se produce una relación entre el color de los atuendos de los personajes y el color de las baldosas del suelo. Gio Ponti (1891-1979) y su relación primera con el mundo de la artesanía cerámica decorativa, y después con el diseño de baldosas cerámicas de pavimento, servirá de ejemplo para analizar algunos de sus proyectos y obras como la Piccola casa ideale (1934) situada en Riviera, o algunos no realizados con Bernard Rudofsky (1905-1988).

También se analizarán sus dos experiencias domésticas en Caracas: la Mansión Planchart 'El Cerrito' (1953-1960) y la Mansión Arreaza 'Villa Diamantina' (1954-1958), dos obras donde el pavimento acompaña la atmósfera telúrica a través de los meta-terrazzos, pero también donde establece relaciones de simpatía con el techo.

E igualmente se analizarán el Hotel Parco dei Principi (1960-1961) en Sorrento y la sede 'Salzburger Nachrichten' (1976) donde se encuentran superficies pavimentadas que pretenden presentarse casi como palimpsestos, como unos suelos que con el frágil espesor de la cerámica depositan en su disposición —con jerarquías no aparentes- casi el único modo de incorporar la densidad del tiempo sobre ellos. De algún modo, en estas dos obras se presenta al pavimento cerámico como si el tiempo hubiera desprendido algunos fragmentos y los siguientes constructores, con una lógica distinta, hubieran decidido recomponer esas ausencias. Gio Ponti, en su obra, se encarga de que las superficies horizontales se entiendan como nuevas huellas sobre paisajes horizontales ya hollados.

En el capítulo «El pavimento en Venecia. Metáforas acuosas» las fotografías de Gianni Berengo Gardin (1930-) durante el acqua alta, establecerán un hilo conductor sobre la convivencia en el plano horizontal de la ciudad del agua y de las actividades. En algunas de sus imágenes, se captura con precisión ese momento ambiguo donde no termina de sumergirse la ciudad, ni acaba por emerger el suelo.

Y es que en Venecia no hay suelo. En Venecia no hay pavimento. O no lo hay de forma permanente y en estado sólido al ser conquistado éste por el agua una y otra vez. El suelo nos convoca cada día en su infinita extensión y en su esperada solidez; y que el suelo nunca deja solo a la especie. $Y$ es verdad. Pero las permanentes inundaciones de Venecia hacen que, tantas veces, el único pavimento de la ciudad se manifieste en forma de pasarelas mínimas que garanticen la circulación básica de los peatones. Es decir, en Venecia, el ciudadano se siente huérfano de pavimento. Y por tanto, el suelo no es aquí una presunción primaria: es un elemento valioso y añorado, es una conquista diaria que libra la ciudad y sus habitantes contra la naturaleza y es, en definitiva, un plano etéreo - casi imaginario- que se desvela con la elegancia que le otorga la horizontalidad artificial. Se analizarán algunas iglesias, palacios y plazas históricas de la ciudad y su relación con la metáfora del agua. 
Esta condición del pavimento entendido como un elemento de la infraestructura lo supo leer bien Carlo Scarpa (1906-1978) en dos de sus obras venecianas: la Tienda Olivetti (1957-1958) en la Plaza de San Marcos de Venecia o la Fundación Querini Stampalaia (1961-1963), donde el pavimento interior recibe también la función de recoger, distribuir y canalizar el agua.

En el capítulo «El pavimento y el umbral. Entre dos mundos» se desarrollan las experiencias de algunos miembros del Team 10 como Aldo van Eyck y Peter y Alison Smithson. El interés por recuperar los espacios urbanos colectivos, no sólo como infraestructuras de tránsito, sino como lugares de estancia, les llevó a poner en valor el jardín, el patio, la calle o la plaza. Y a servirse de los pavimentos para colonizar los paisajes urbanos, para construir las nuevas identidades de la colectividad, para establecer convergencias entre los diferentes. Se analizarán los pavimentos de algunos parques diseñados por Aldo van Eyck en Amsterdan. Pero también se explicarán los pavimentos encontrados de Upper Lawn (1959-1962) de Alison y Peter Smithson. Los límites pavimentados difusos que Alvar Aalto propone en Villa Mairea (1937-1939). O el umbral pavimentado que proyecta Gunnar Erik Asplund en la Villa Snellman (1917-1918) en Djursholm. También se analizará el ejemplo del Tribunal del Condado de Lister donde el pavimento se adapta a las trazas del vestíbulo de entrada.

En el capítulo «El pavimento y el fragmento. El tiempo y la memoria» se estudiarán las experiencias de Dimitris Pikionis en Grecia, sobre todo en la Acrópolis de Athenas (1953-1958) o la casa para el escultor Efthymiadou (1949). También se analizará el pavimento de la Casa Experimental de Vacaciones (19521954) en Muuratsalo de Alvar Aalto. Y como cierre, se estudiará el pavimento del Cementerio de la Igualada (1984-1994) de Enric Miralles. 
Pavimentos: huellas fenomenológicas, registros arqueológicos y planos de referencia 


\section{Bloque I: referentes}



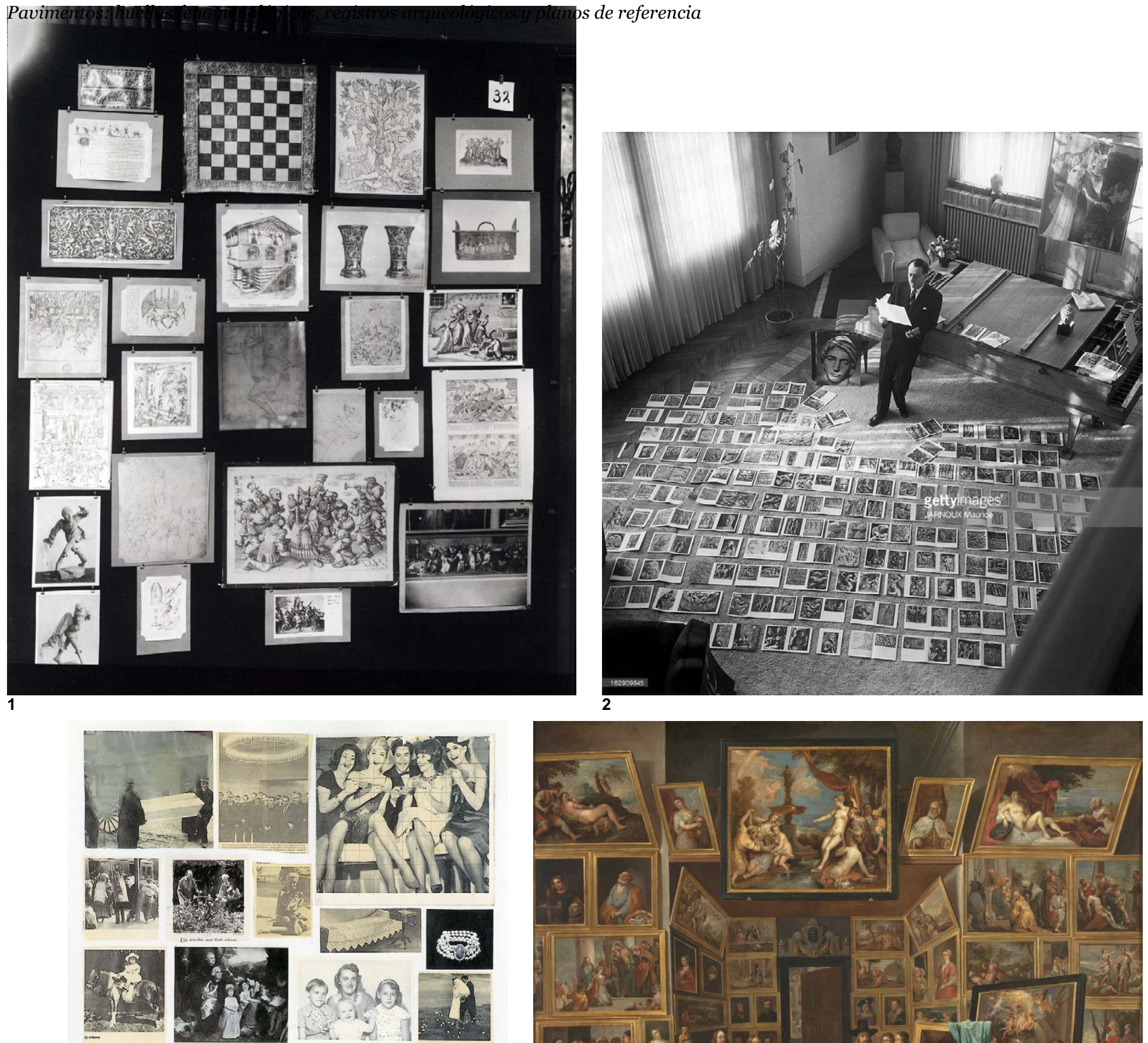

3

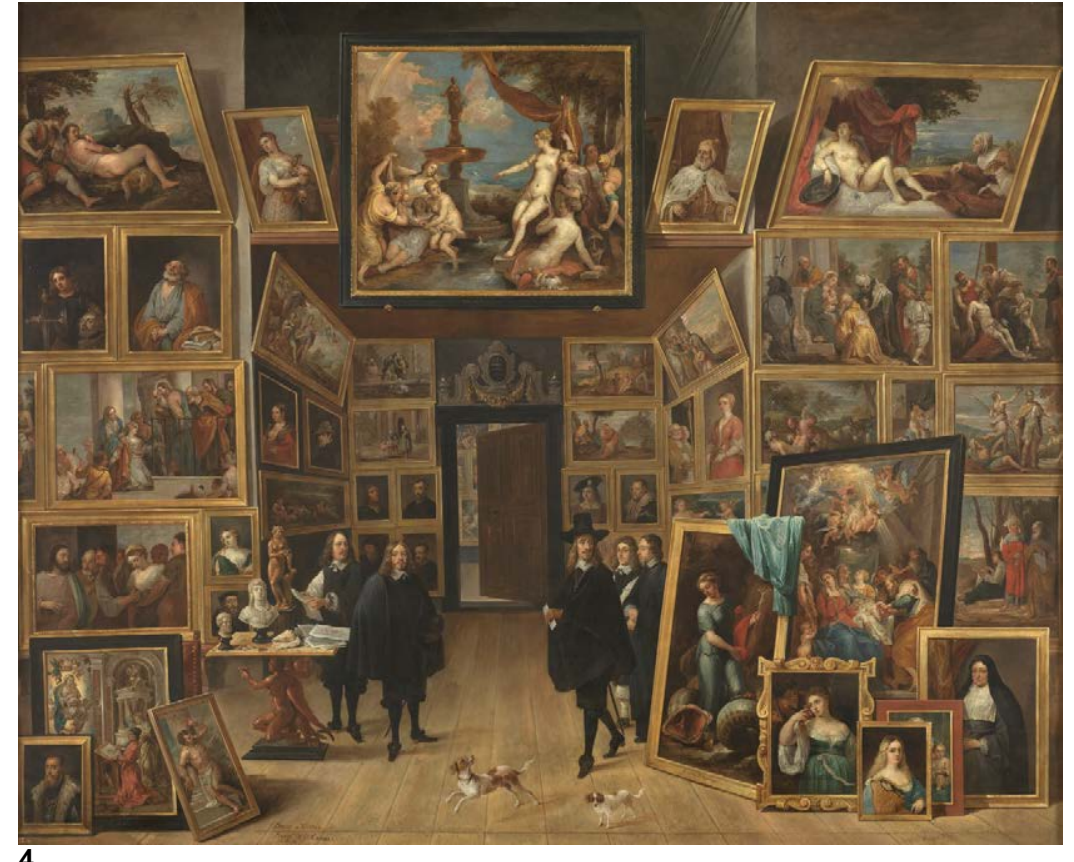

1. Lámina 32. Mnemosyne Atlas / Bilderatlas Mnemosyne (1927-1929). Aby Warburg. (Técnica: Fotografía) [F uente: Warburg Institute Archive, Londres]

2. Andre Malraux and his imaginary Museum

(1953). J arnoux Maurice. (Técnica: Fotografía.

Dimensiones: $91,37 \times 95,18 \mathrm{~cm}$ ). [Fuente: París

Match / (c Getty Images. 162909845 / M 0004653]

3. Atlas Blatt, 9. Zeitungs- \& Albumfotos.

Newspaper \& Albumphotos (1962). Gerhard

Richter. (Técnica: Fotografía. Dimensiones: $51,7 \times$

$66,7 \mathrm{~cm}$ ). [Fuente: (c) Gerhard Richter]

4. El archiduque Leopoldo Guillermo en su galería

de pinturas en Bruselas, (1647-1651). David

Teniers. (Técnica: Óleo sobre lámina de cobre.

Dimensiones: 104,8 x 130,4 cm) [Fuente: OMuseo

del Prado de Madrid. P001813]

5. Museo del Prado, sala de la reina Isabel II

(c1899). J uan Laurent y Minier. (Técnica: Colodión

sobre papel fotográfico. Dimensiones: $28 \times 38,5$

$\mathrm{cm}$ [ [Fuente: $\mathrm{OMuseo}$ del Prado de Madrid.

HF 01092]

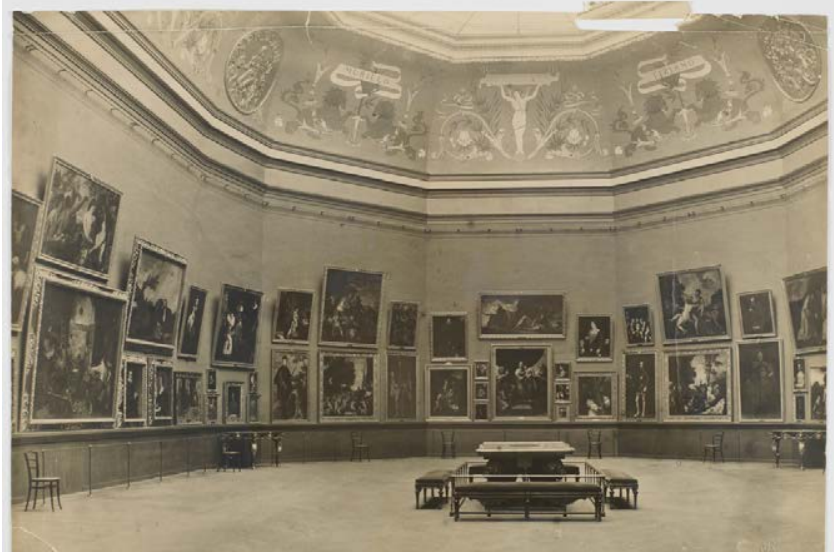




\section{|}

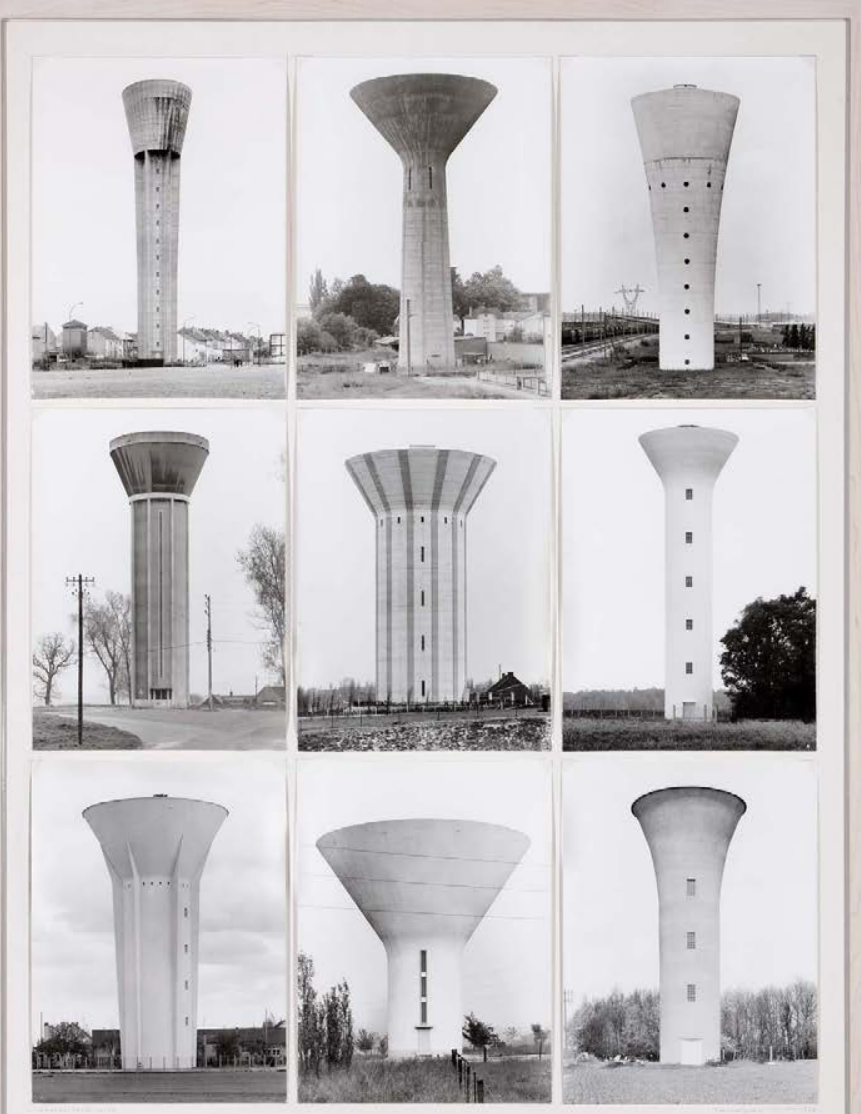

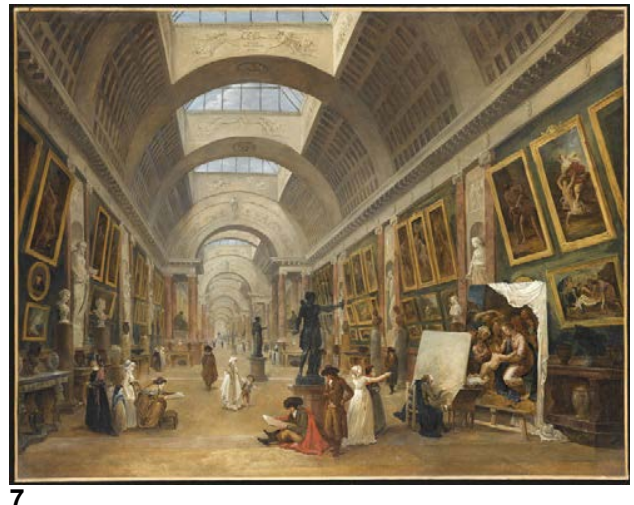

$$
7
$$
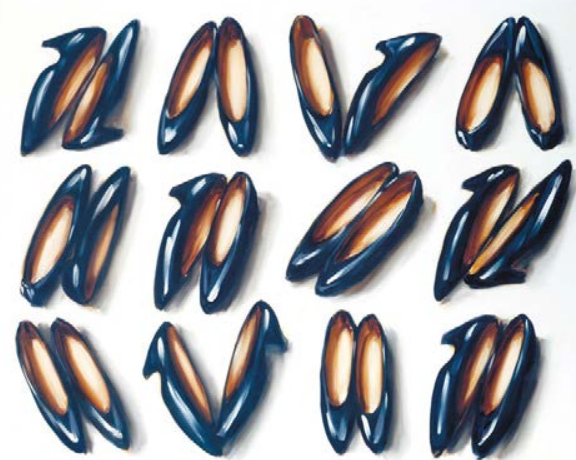

8
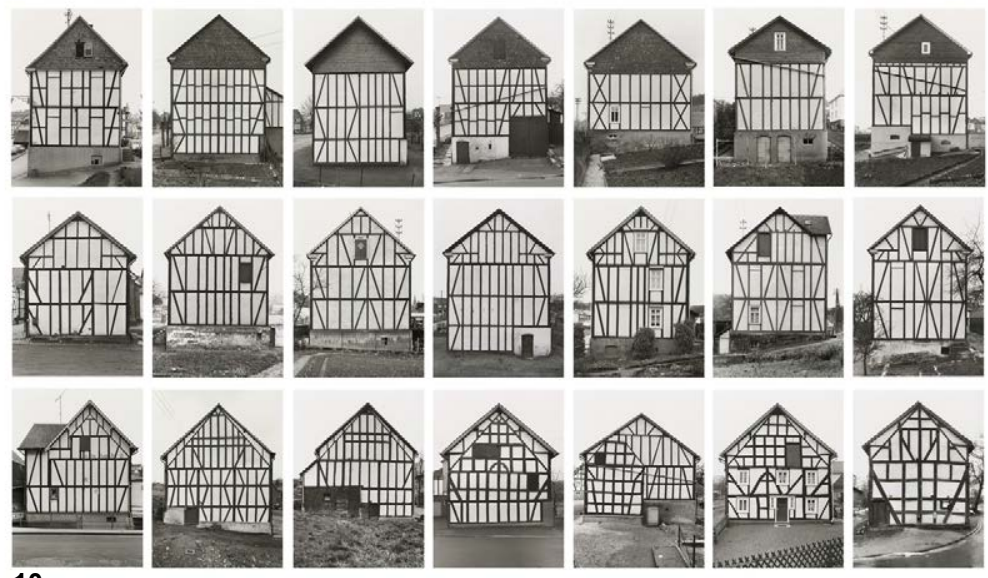

6. La Vista, (1617). Pedro Pablo Rubens y Jan Brueguel EI Viejo. (Técnica: Óleo sobre tabla. Dimensiones: $64,7 \times 109,5 \mathrm{~cm}$ ). [Fuente: @Museo del Prado de Madrid. P 001394]

7. Project pour la transformation de la Grande Galerie (1796). Hubert Robert. (Técnica: Huile sur toile / Óleo sobre tela. Dimensiones: $143 \times 113$ $\mathrm{cm}$ ). [Fuente: @RMN-Grand Palais (Musée du Louvre) / J ean-Gilles Berizzi]

8. Shoes (1985). Lisa Milroy (Técnica: Oil paint on canvas. Dimensiones: 174,6 × 226,5 x 0,56 cm) [Fuente: CTATE, Londres. PT06532]

9. Typology of Watertowers (Tipología de torres de agua) (1972). Bernd Becher y Hilla Becher.

(Técnica: Gelatinobromuro de plata sobre papel. Dimensiones: 148 x $108 \mathrm{~cm}$ con marco) [Fuente: CMuseo Nacional Centro de Arte Reina Sofía, Madrid. D001532]

10. Framework Houses, (1959-1973). Bernd Becher y Hilla Becher. (Técnica: 21 gelatin silver prints. Dimensiones: $41,2 \times 30,5 \mathrm{~cm}$ con marco) [Fuente: OMoMA. The Museum of Modern Art. 505.2009.a-u] 


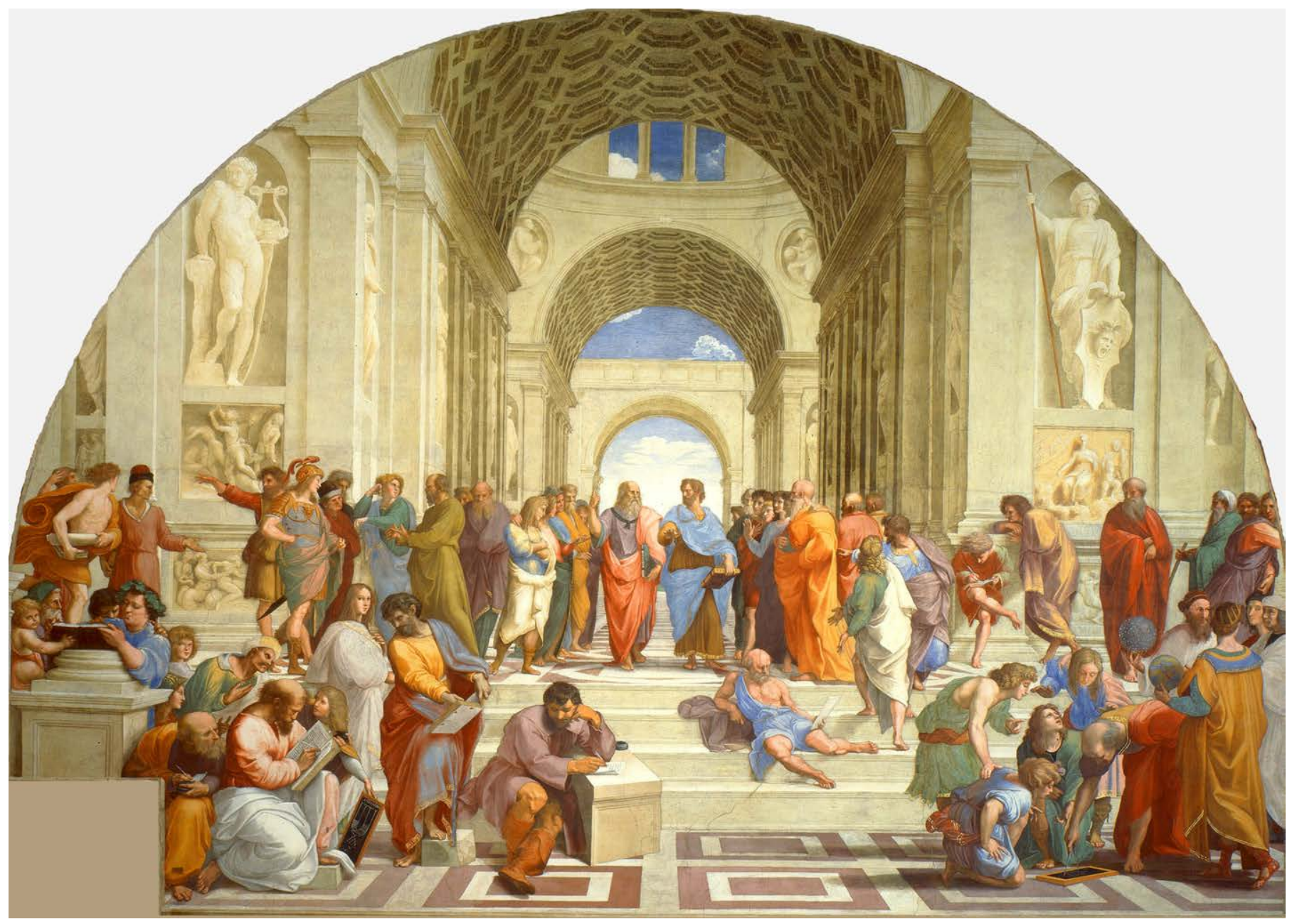

Figura.

La Scuola di Atene / La escuela

de Atenas (1509). Rafael San-

zio. [Fuente: OMusei Vaticani] 


\section{La Scuola di Atene (1509) Rafael Sanzio}

La escena se sitúa en un ambiente arquitectónico romano, inspirado en Bramante. Este fresco, pintado por Rafael Sanzio, está situado en la sala de la signatura en el Vaticano - hoy en el recorrido de los Museos Vaticanos- , y muestra a los filósofos, matemáticos y científicos más importantes de la época clásica. La escena está presidida por Platón y Aristóteles, situados en el centro. El primero, que lleva consigo el libro el Timeo, está señalando con la punta de los dedos al cielo - al techo-; y el segundo, con la Ética en una mano, señala con la otra a la tierra - al suelo- Se plantea, por tanto, la eterna dualidad entre los sueños y la realidad. El idealismo y el realismo. Lo divino y lo humano. El cobijo o la plataforma. La seguridad trascendental del suelo, o la incertidumbre (y el milagro) de la cubrición.

También en las hornacinas del primer plano, situadas a ambos lados de la bóveda, parece plantearse esta discusión: Apolo parece mirar de reojo al techo, y Minerva insiste en bajar la mirada hacia el suelo. El resto de hornacinas bajo la bóveda está cuajada de personajes unos señalando hacia abajo y otros hacia arriba. $Y$ en un plano más retrasado al fondo, en los medallones situados bajo la cúpula, se observa a la izquierda un hombre que en efecto alza la mirada, y a la derecha, la mujer posa su mano sobre un globo terrestre.

Aunque en la obra exista una voluntad de fidelidad por la simetría - des- de la perspectiva hasta el número de personajes que equilibran la escena- lo cierto es que se produce nuevamente una tensión hacia el suelo. Es el caso de la acumulación de personajes de la derecha, liderados por Euclides - encarnado en Bramante- que está haciendo alguna comprobación con el compás sobre una pizarra en el suelo, ante el asombro de algunos. 0 Diógenes, literalmente acostado sobre el peldañeado. 0 Heráclito - encarnado en Miguel Ángel- que se encuentra sentado en el suelo y apoyado sobre un bloque de piedra escribiendo y meditando, mirando de nuevo hacia abajo.

El espacio se divide en dos niveles, separados por cuatro peldaños. Los protagonistas se sitúan arriba, donde el pavimento recibe la proyección, más o menos, de los casetones del techo: los hexágonos del techo, que están intercalados con cuadrados, se convierten en el pavimento en octógonos inscritos en marcos cuadrados, con otro cuadrado, también blanco, en el interior. Se trata de una interpretación libre de una homotecia. En el nivel inferior, el despiece del pavimento se realiza con grandes piezas cuadradas, con otros cuadrados concéntricos, y que también pudiera ser una proyección de su techo, pero que el pintor decide eludir. 


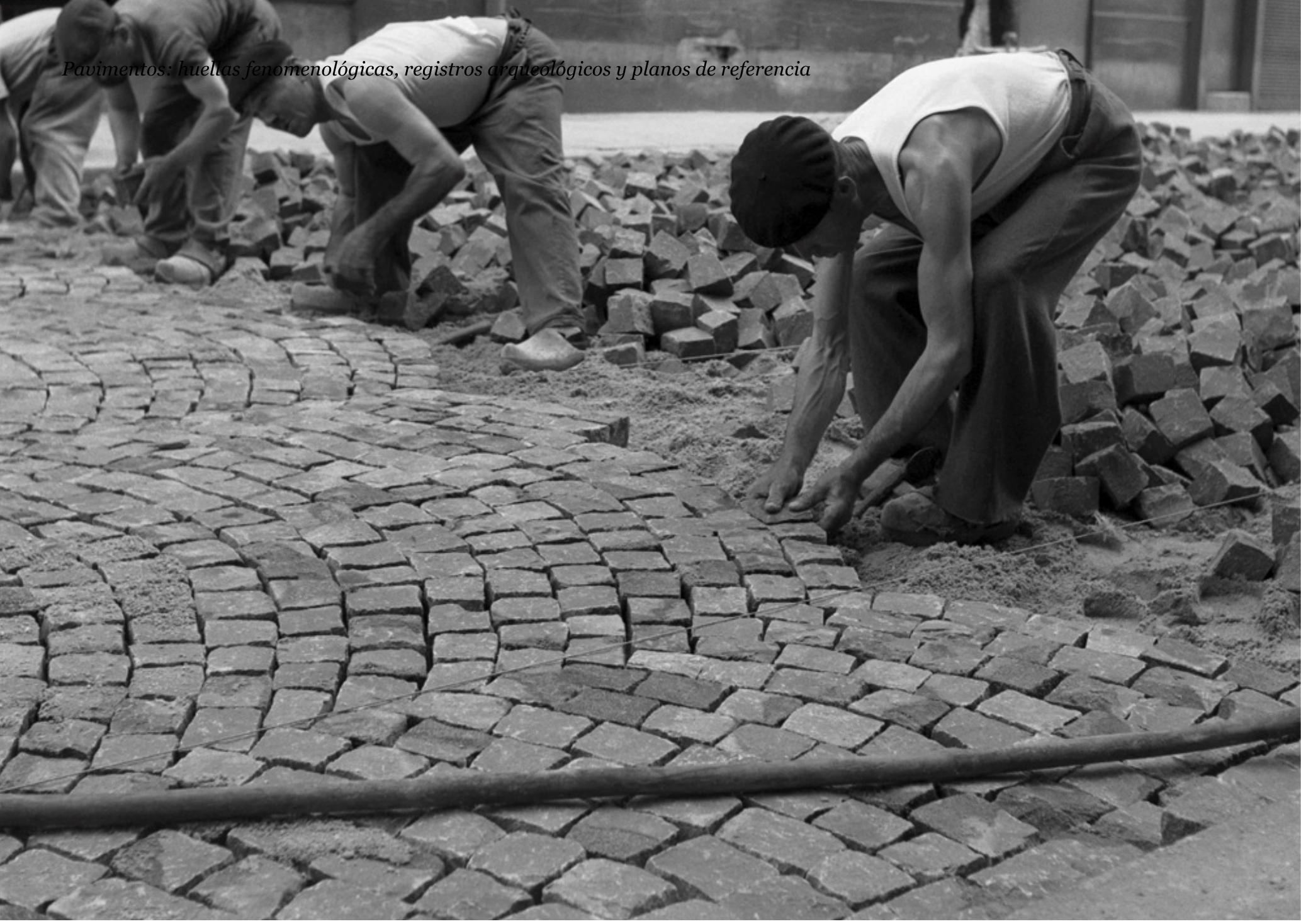




\section{CAPÍTULO 1}

\section{Introducción Suelos y pavimentos}

\section{Introducción}

A veces olvidamos donde se posan nuestros pies. La mirada y los ojos se deslizan sobre el plano del suelo anhelando respuestas. El suelo nos convoca cada día en su infinita extensión. Y en su esperada solidez. Y en su prometida e infiel horizontalidad. El suelo nunca deja huérfana a la especie humana: le acompaña por las veredas, por los senderos, por los caminos. Y le espera en la casa, en el umbral, en el pasillo, en la alcoba, en las cocinas y en los patios. Los usuarios no pueden evitar la servidumbre de pisar permanentemente sobre un suelo. Nuestra relación con el suelo es íntima e ineludible.

La tesis Pavimentos: huellas fenomenológicas, registros arqueológicos y planos de referencia pretende reflexionar sobre la evolución de la arquitectura del Movimiento Moderno a través de los planteamientos teóricos y de las estrategias proyectuales tomando como tema central el pavimento.

Entendemos pavimento como el revestimiento artificial construido sobre el suelo natural o sobre una solera. Si bien, en este trabajo de investigación, se empleará la palabra 'pavimento' o 'suelo' indistintamente para evitar la redundancia sonora. Y cuando se haga referencia al suelo natural, se explicitará.

El ámbito de estudio se centra en algunas obras del Movimiento Moderno del tercio central del siglo XX. Que abarcan algunas obras de la modernidad ortodoxa, pero sobre todo algunas obras seleccionadas de la segunda generación del Movimiento Moderno. Se estudiarán ejemplos de Mies van der R ohe, Gio Ponti, Carlo Scarpa, Alison y Peter Smithson, Alvar Aalto, Erik Gunnar Asplund o Dimitris Pikionis.
Figura 0. Página anterior. Cobblestone Layers (1950). Benjamen Chinn. [F otografía: (CBenjamen Chinn Photographics Archive. 2014.72.11] 


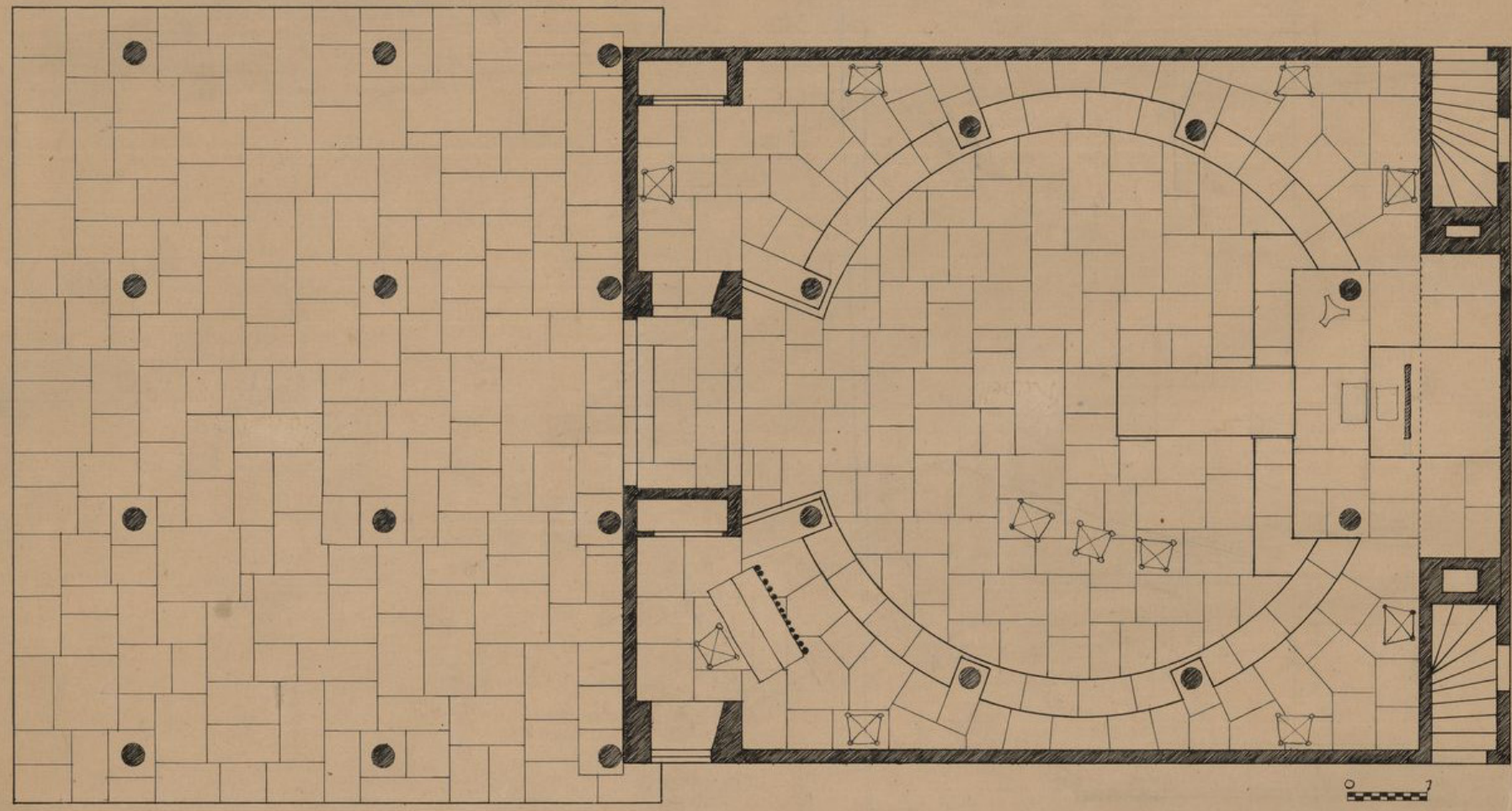

Figura 1.

Ground polan for Woodland

Chapel showing furniture

placement and tile flooring

Woodland Cementery,

Stockholm, Sweden (1920)

Erik Gunnar Asplund. [Fuente:

oCCA. Canadian Centre for

Architecture, Montreal]
[1] Forgioni-Flórez, Ivan-Leonardo. «Bajo los pies. El suelo como generador del espacio moderno». Director: María-Cristina Vélez-Ortiz. Medellín: Universidad Nacional de Colombia, Facultad de Arquitectura, 2014. Tesis para optar al título de Magister en Arquitectura.

[2] Molina-Rodríguez, Santiago de. «Elogio del suelo». En: Múltiples estrategias de Arquitectura. Madrid: Ediciones asimétricas, 2013. p. 47.

[3] Moro, J osé-Luis. Flooring. Volume 2. Design. Life cycle. Case Studies. Berlín: DETAIL Practice Book e Institut für internationale Architektur-

Dokumentation GmbH \& Co. KG, 2016.
La tesis construye un diálogo comparado entre épocas diversas estableciendo como hilo conductor el pavimento - entendido como 'fragmento' o como 'elemento'- y su relación con el resto de elementos que conforman el espacio arquitectónico como son, por ejemplo, el techo, la estructura, los huecos, o incluso el mobiliario y el ajuar doméstico. El trabajo de investigación también estudia la presencia del pavimento en el espacio imaginado de la pintura, en la fotografía, en la literatura o en el cine.

El pavimento combina conceptos de textura y dimensión - también de límiteque definen un espacio interior o exterior. Es interesante su escala y proporción, su composición y geometría, si está formado por partes o su disposición es continua, el despiece de las piezas o el tamaño de las juntas. El suelo tiene la posibilidad de crear recintos reconocibles, y sus trazas tantas veces presagian la lógica compositiva y constructiva de algunas arquitecturas. El suelo es, además, más antiguo que la columna, el muro o el techo; y es un elemento casi perenne que, en el ocaso y ruina de algunas arquitecturas, permite su reconstrucción. El pavimento puede considerarse, de algún modo, una arquitectura condensada que, a falta del cobijo, ya presagia un lugar.

Construido sobre los cimientos o la solera, está íntimamente relacionado con los estilóbatos, los podiums y las plataformas. También lleva consigo el peso intelectual de la función, del uso y de la representación de un espacio arquitectónico. Y, desde luego, el suelo pavimentado asume una carga simbólica, a veces, alejada de la razón.

EI suelo es responsable de soportar el peso, es la base confiable sobre la que se deposita todo cuanto sucede. Es la superficie donde nos entregamos sin condiciones con la tranquilidad de encontrarnos de nuevo con la horizontalidad prometida. 0, al menos, con la planeidad. Los ojos, la boca, la nariz y los oídos, que fisionómicamente están orientados al frente, se han acostumbrado al plano horizontal. Pero sin duda es el suelo, como arquitectura de contacto, el que define con mayor potencia nuestra relación con el mundo, al menos nuestro mundo 
[1]. La confianza en el confort contemporáneo nos hace presuponer que nos vamos a encontrar una superficie horizontal perfecta en nuestro entorno habitado. Por lo tanto, sobre el suelo se delegan muchos de los privilegios de los que disfruta el hombre moderno.

J osep María Sostres Maluquer (1915-1984) explicaba que la especie humana le debe al plano horizontal del suelo la capacidad de reflexión. Quizá sea algo exagerado, pero según él, durante la evolución desde los primeros homínidos, el hombre ha caminado algo trastabillado, poniendo atención siempre al suelo natural irregular para no perder el equilibrio. Y que con la aparición de la superficie horizontal pavimentada, el hombre bípedo ya podía despreocuparse de los obstáculos y levantar la mirada, pudiendo contemplar tranquilamente el horizonte, llegando a convertirse en un homo sapiens pensador [2].

Cuando el suelo se vuelve discontinuo e inestable, la inseguridad hace que sobre nuestros ojos, nuestras manos y nuestros pies recaiga la responsabilidad final del equilibrio. Y es que el suelo pavimentado horizontal es el artificio que nos permite levantar la mirada que, hasta entonces, estaba dirigida hacia el suelo áspero de la naturaleza. A diferencia de otros elementos, el suelo pavimentado no se rompe. Por lo tanto, el suelo es un elemento de tranquilidad, de confianza y de confort. Por ello los suelos también deben satisfacer las demandas de un elemento de la construcción sometido a un uso extremo [3].

Martin Heidegger (1889-1976), el padre de los metafísicos contemporáneos, en el ensayo El origen de la obra de arte (1935-1936) nos dice:

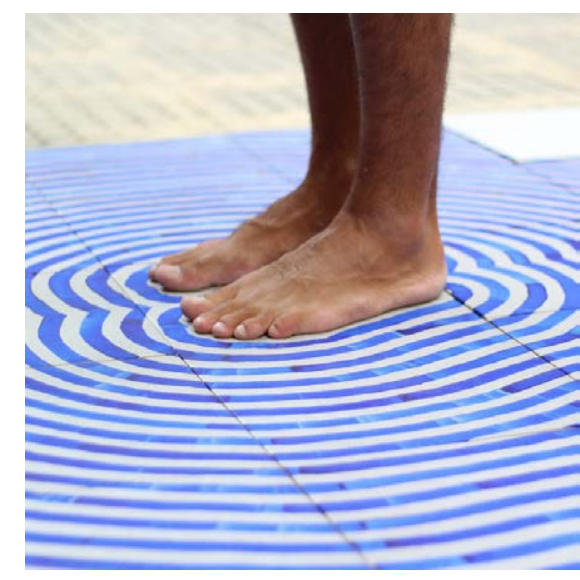

Figura 2. Huella. Build your own world (2015). [Fuente: CAlejandro Ontiveros Robles]

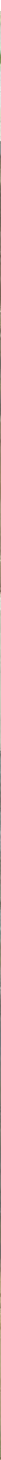

Figura 3. José Rico Cej J OMuseo Carmen Thyssen de Málaga. CTB.2001.17] 


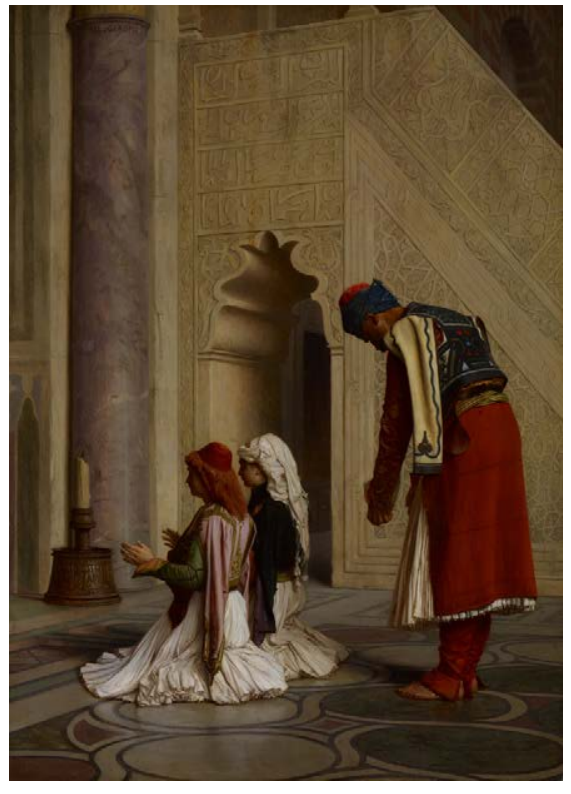

Figura 4.

Young Greeks in the Mosque

(1865). J ean-León Gérôme.

[Fuente: OMinneapolis Institute

of Art OThe Christina N. and

Swan J. Turnblad Memorial

Fund. 62.85]

Figura 5. Página siguiente. Church of Santa Maria dell'Ammiraglio (La Martorana),

Palermo, Silicy: details of

mosaic floors (1149-1880). J ames Howard Ince. [Fuente: ORIBA Collections / Architectural Press Archive. RIBA97895]

[4] Heidegger, Martin. Leyte-Coello, Arturo (trad.) y Cortés-Gabaudan, Helena (trad.). El origen de la obra de arte / Der Ursprung des Kunstwerkes.

Madrid: La Oficina de Arte y Ediciones, 2016.

[5] Koolhaas, Rem (ed.) y Easterling, Keller.

«Floor». En: Elements of architecture. The Venice Biennale. 14th International Architecture Exhibition. Venezia: Marsilio Editori, 2014. p. 4.
«La tierra sólo se muestra como ella misma, abierta en su claridad, allí donde la preservan y la guardan como lo esencialmente indescifrable que huye ante cualquier intento de apertura; dicho de otro modo, la tierra se mantiene constantemente cerrada. Todas las cosas de la tierra, y ella misma en su totalidad, fluyen en una reciproca consonancia. Pero este fluir no es una manera de borrarse. Lo que aquí fluye es la corriente de la delimitación que reposa en sí misma y limita en su presencia a todo lo que se presenta. Así, cada una de las cosas que se cierran en sí mismas se desconocen unas a otras en la misma medida. Emplazar tierra significa llevarla, en tanto aquello que se cierra a sí mismo, a lo abierto» [4].

Pero el pavimento es también el artificio que nos recuerda que alguien antes ha estado ahí. Es una marca sobre el infinito suelo natural de la Tierra. Es un plano de confianza y de confort. El suelo (natural) es encontrado, y el pavimento (artificial) es fabricado sobre la naturaleza.

El pavimento es el elemento donde se establece el contacto entre la tierra y los hombres. Es el lugar donde se produce el acuerdo entre la gravedad y el cuerpo vertical [5]. La mayoría de las actividades humanas se realizan sobre planos horizontales, ya que las pendientes o las rampas se vinculan más al desplazamiento que al destino, al tránsito mientras nos movemos, que a la posición estática e inmóvil donde desarrollar una actividad. Si bien, la historia de la arquitectura ha legado hermosos planos inclinados de los que se hablará en el Capítulo 9: «El pavimento inclinado. Anhelo natural». El plano horizontal confirma, de algún modo, la verticalidad del hombre. También el pavimento se desarrolla en una dirección contraria a la gravedad.

Cada pisada sobre su superficie nos remite a una huella de su memoria, a un pasado reciente y cada nuevo paso presagia un porvenir inminente, un futuro inesperado. Desplazarse sobre un pavimento es reconocerse inmerso en un campo de juego que establece vínculos con el espacio y con el tiempo.

Los pavimentos, además, desempeñan un papel fundamental en la percepción de un lugar, tanto en los ámbitos exteriores como en los recintos interiores ya que los revestimientos horizontales de los recintos cerrados y las superficies de

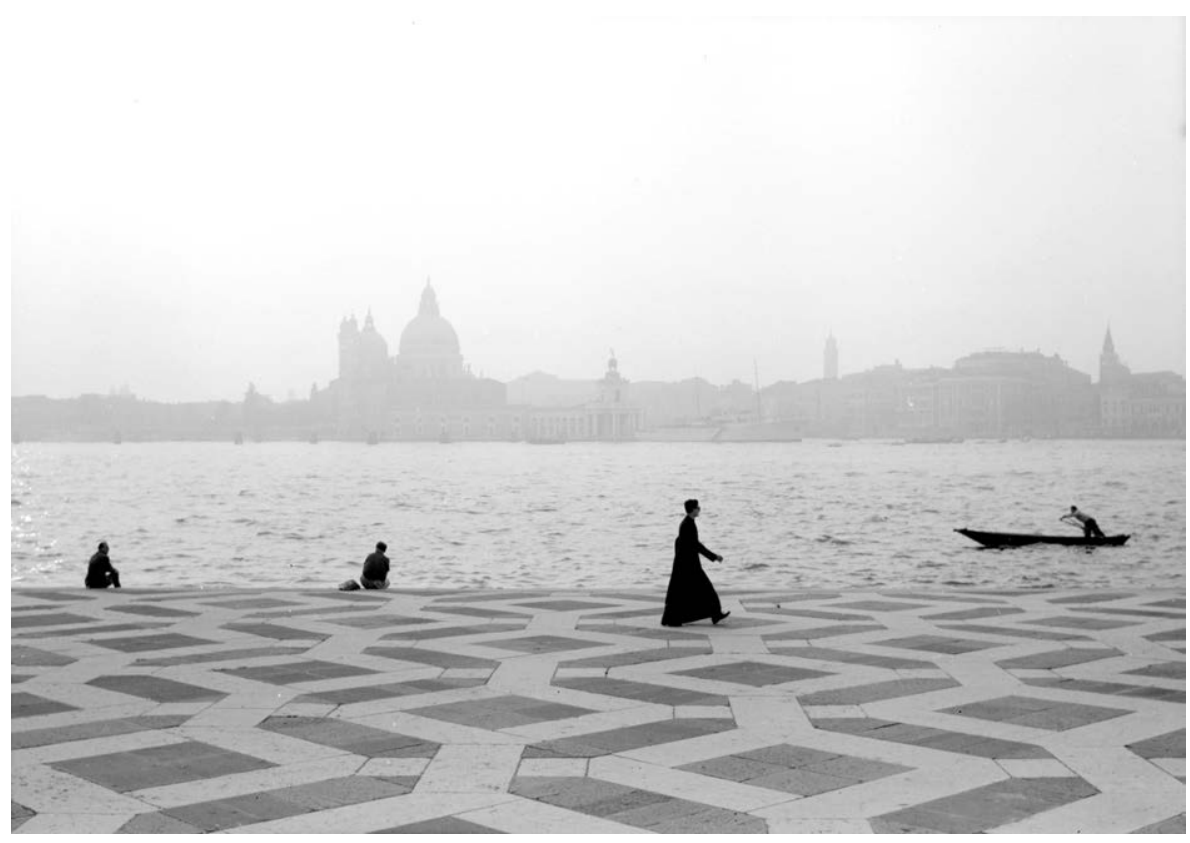




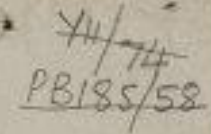

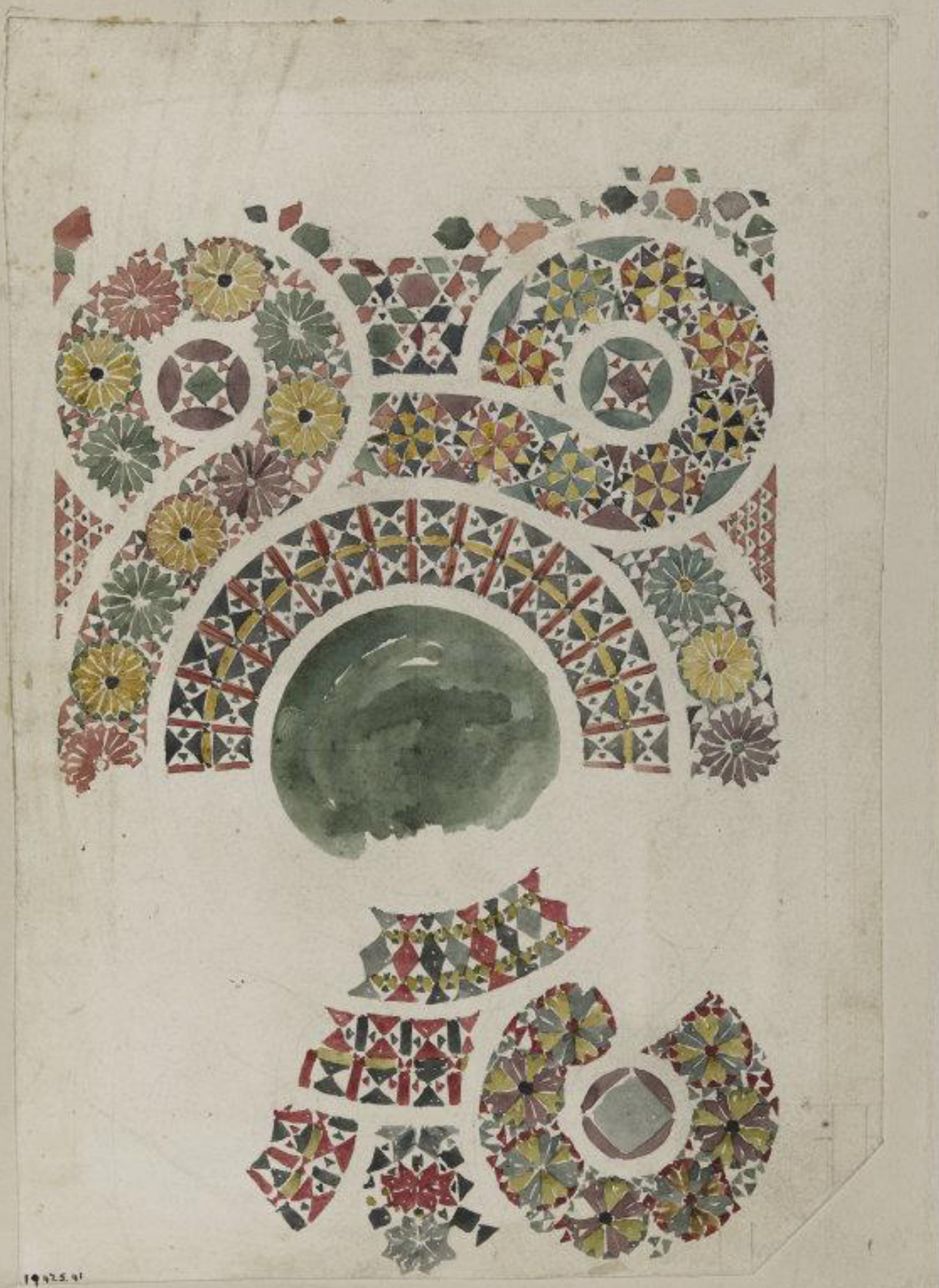




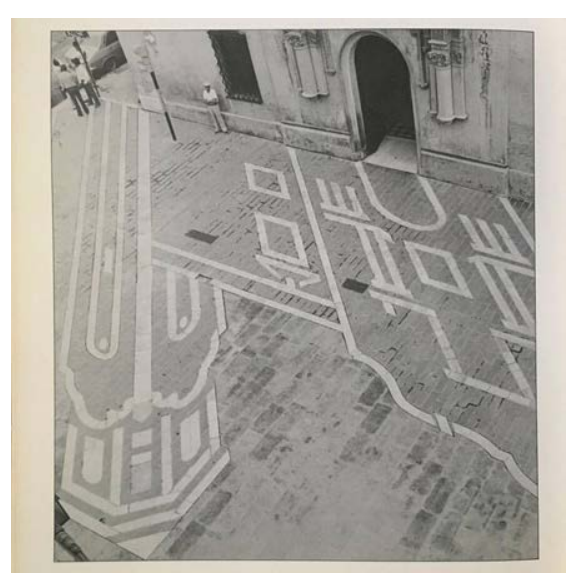

Figura 7

Plaza de Armas, Córdoba (Argentina) (1980). [Fuente: OSF ] los espacios exteriores se ven influidos por la materialidad y apariencia de sus pavimentos.

El pavimento ha sido un testigo mudo (y silente) de prácticas culturales, ceremonias conmemorativas, festejos alegres o funerales definitivos. La dicha y la desdicha han sucedido sobre él. Y lo seguirán haciendo.

\section{Suelo exterior}

La naturaleza siempre fue un medio hostil y peligroso, un espacio sometido a los distintos elementos. Sin una huella horizontal reconocible sobre el infinito suelo natural, la especie humana no puede encontrar un lugar donde poder establecerse.

Rex Distin Martienssen (1905-1942) explicaba, en su tesis doctoral La idea del espacio de la arquitectura griega [6], que una de las primeras conquistas del hombre para satisfacer las necesidades más primarias implicaba «una modificación mínima del medio natural» mediante la explanación mínima del terreno. Según Massimo Cacciari (1944-): «un espacio surge cuando talando, roturando, se produce das Frei, das Offene, lo libre y lo abierto, para que el hombre se establezca y lo habite» [7].

De algún modo, en su tesis, defendía que la propia elección del lugar y diseño de un plano horizontal sobre el suelo natural era ya un presagio de hogar. Así, establecer un suelo artificial de forma premeditada, formaba parte de la primera operación de todo aquel que quisiera crear un marco conceptual y físico para el desarrollo de la actividad humana. $Y$ es que algunas arquitecturas se sirven del suelo como el principal y primer instrumento para construir un lugar, un ámbito para separarnos del suelo natural [8].

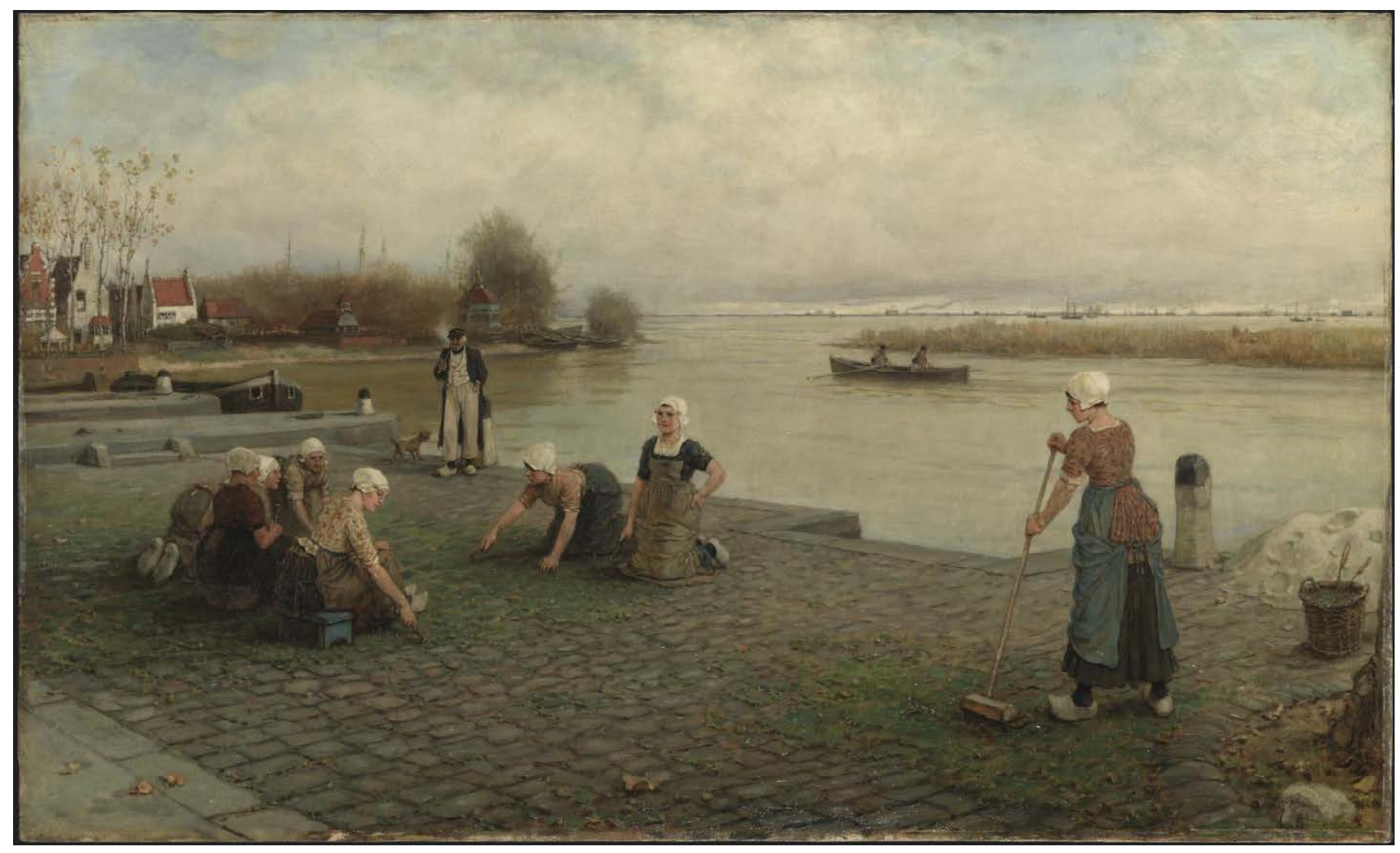




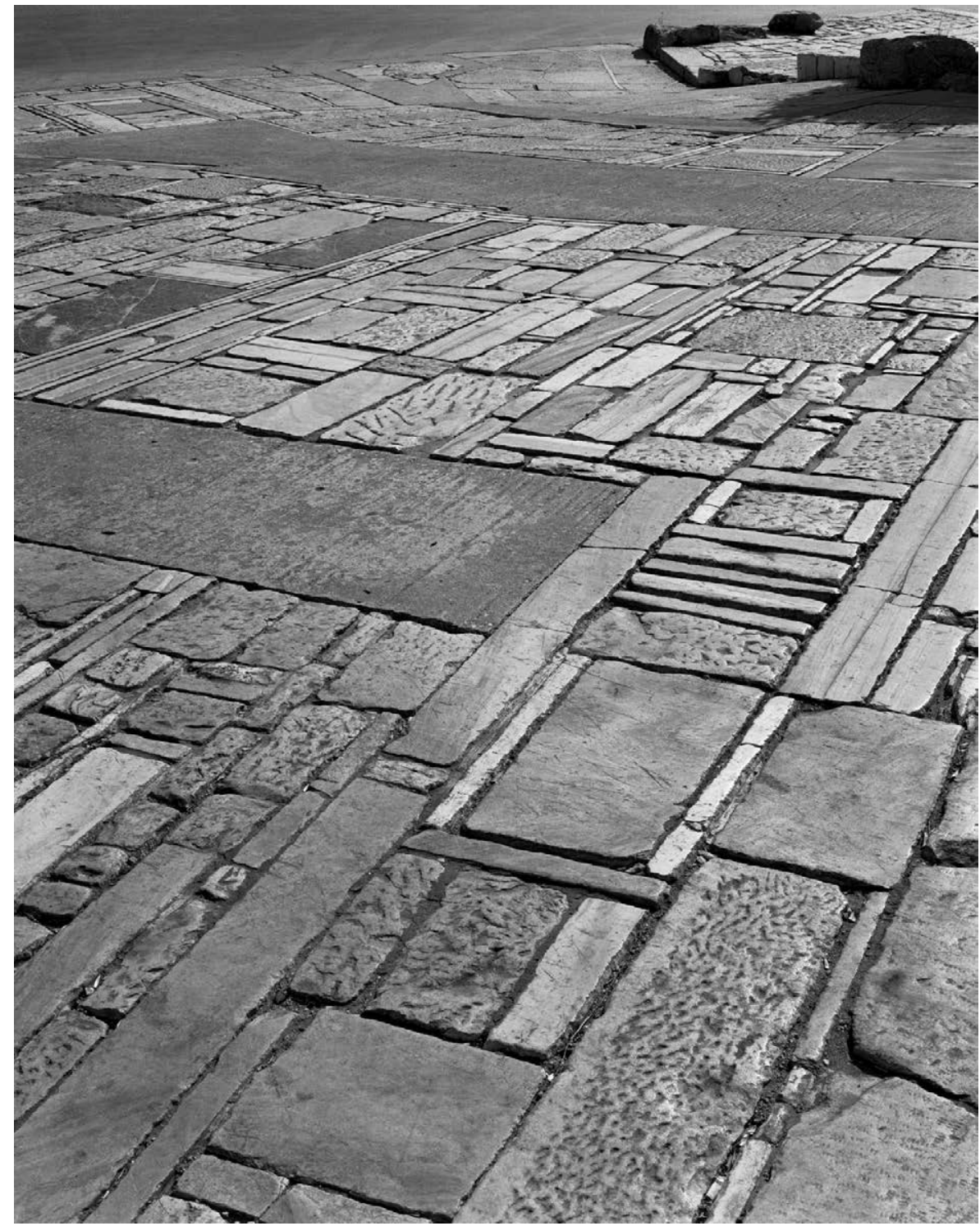

Para Martienssen, los elementos que constituían un templo eran: la terraza, el muro, la columna y el dintel. Por tanto, la definición, demarcación mensurable y reconocible de un límite entre el espacio donde se desarrollan actividades humanas sobre un plano horizontal y el medio natural circundante, parece una condición ineludible para que se constituya un lugar.

Pero en esos elementos también se define una noción de orden y sistema, proponiendo al suelo como el primer elemento para definir un espacio [9]. Y por tanto, en su tesis aborda precisamente el tema de la terraza y el pavimento.

«La creación de un plano o nivel de referencia, dentro de un contexto práctico, tiene una significación mucho más amplia que la derivada de su aspecto puramente 'útil' en una disposición arquitectónica.

La primera condición de cualquier sistema de organización formal destinado a abarcar las actividades de la vida organizada o colectiva es un plano horizontal o una serie de planos horizontales relacionados. El equipo sensorial del hombre exige, por su naturaleza, esa estabilidad visual que sólo las superficies planas son capaces de ofrecer; $y$ aún en la definición menos compleja del espacio utilizable — vale decir, utilizable por el hombre como ente perceptor y móvil- el generador del sistema es una

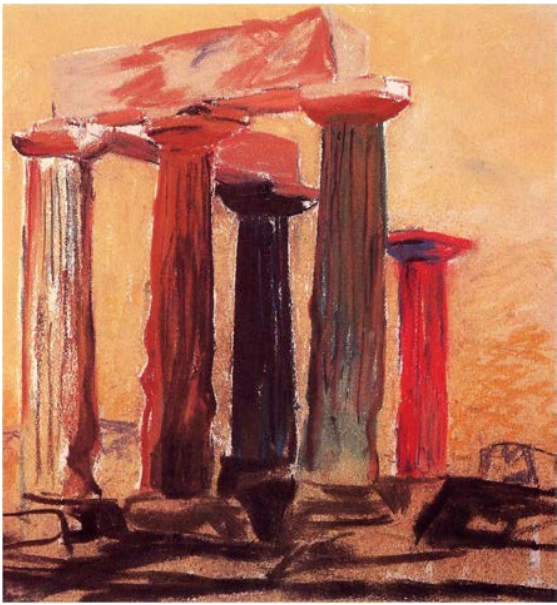

Figura 9

Sketch, Temple of Apollo Corinth (1951). Louis I. Kahn. [Fuente: OLouis I. Kahn Collection @Yale University]

Figura 10.

Pavimentos de los Caminos de

Subida a la Acrópolis (1953-

1958). Dimitris Pikionis.

[Fotografía: OHélène Binet]

[6] Martienssen, Rex Distin. The idea of space in greek architecture. J ohannesburg: Witwatersrand University Press, 1956.

Martienssen, Rex Distin. La idea del espacio en la arquitectura griega. Buenos Aires: Ediciones Nueva Visión, 1972.

[7] Cacciari, Massimo. Adolf Loos y su Ángel. En: Pizza de Nanno, Antonio (ed.). Adolf Loos. Barcelona: Editorial Stylos, 1989.

[8] Forgioni-Flórez, Ivan-Leonardo. «Bajo los pies. El suelo como generador del espacio moderno». Director: María-Cristina Vélez-Ortiz. Medellín: Universidad Nacional de Colombia, Facultad de Arquitectura, 2014. Tesis para optar al título de Magister en Arquitectura.

[9] Ibíd. 


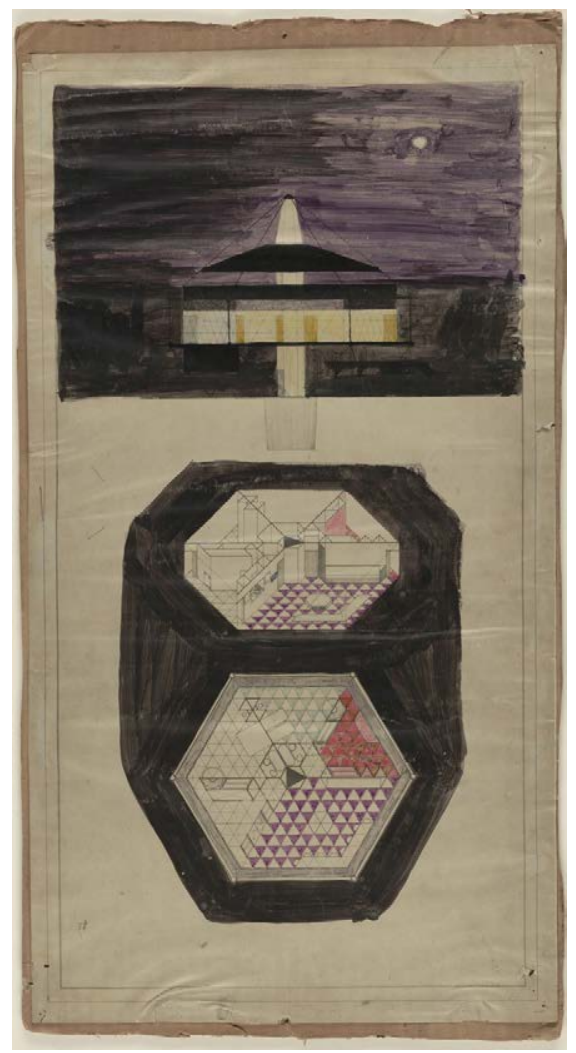

Figura 11

A minimum Dymaxion Home,

project, elevation, axonometric

and plan (c1930). Richard

Buckminster Fuller. [Fuente:

CMoMA. Museo de Arte

Moderno de New York.

1198.2000]

Figura 12.

Maison Cook, Boulogne-sur-

Seine, Francia (1926). Le Corbusier. [Fuente:

(CF oundation Le Corbusier]
[10] Martienssen, Rex Distin. The idea of space in greek architecture. J ohannesburg: Witwatersrand University Press, 1956.

Martienssen, Rex Distin. La idea del espacio en la arquitectura griega. Buenos Aires: Ediciones Nueva Visión, 1972.

[11] Le Corbusier (J eanneret, Charles-Édouard). Vers une architecture. París: Saugnier, 1923. Hacia una arquitectura. Barcelona: Ed. Apóstrofe, 1998. superficie plana que por medios estructurales deliberados niega la irregularidad de las condiciones topográficas existentes» [10].

Por tanto, la plataforma pavimentada permite contemplar la naturaleza desde un 'espacio' que le permite estar aislado del suelo natural hostil. Y a la vez le permite reconocer su belleza al contrastarla con el artificio del plano pavimentado. No se trata de una negación del suelo natural, sino un relato de complementariedad, siendo necesarios ambos. Charles-É douard J eanneret-Gris, Le Corbusier (1887-1965) en su libro Vers une Architecture (1923), realiza esta observación en relación con el suelo artificial de la Acrópolis en relación sobre el accidentado suelo natural sobre donde se apoya:

«Acrópolis de Atenas. Ojeada sobre el Partenón, el Erecteión, el AteneaPartenos, desde los Propileos. No hay que olvidar que el suelo de la Acrópolis es muy accidentado, con diferencias de nivel considerables que se han empleado para brindar pedestales imponentes a los edificios. las falsas escuadras han proporcionado vistas espléndidas y un efecto sutil; las masas asimétricas de los edificios crean un ritmo intenso. El espectáculo es macizo y elástico, de una agudeza aplastante, dominadon» [11].

«El universo de nuestros ojos reposa sobre un llano bordeado de horizonte El rostro vuelto al cielo Consideremos el espacio inconcebible hasta ahora incomprendido.

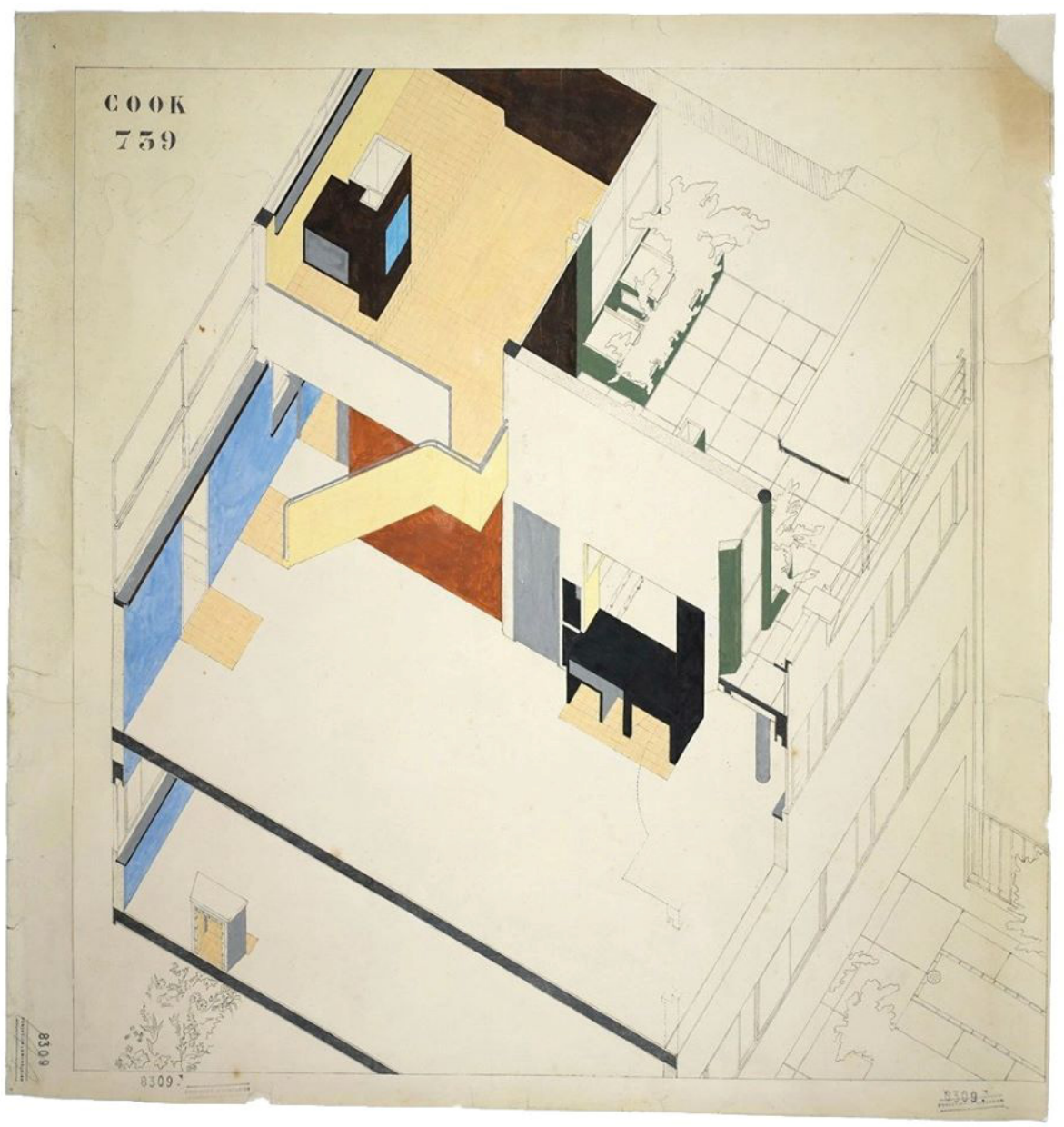




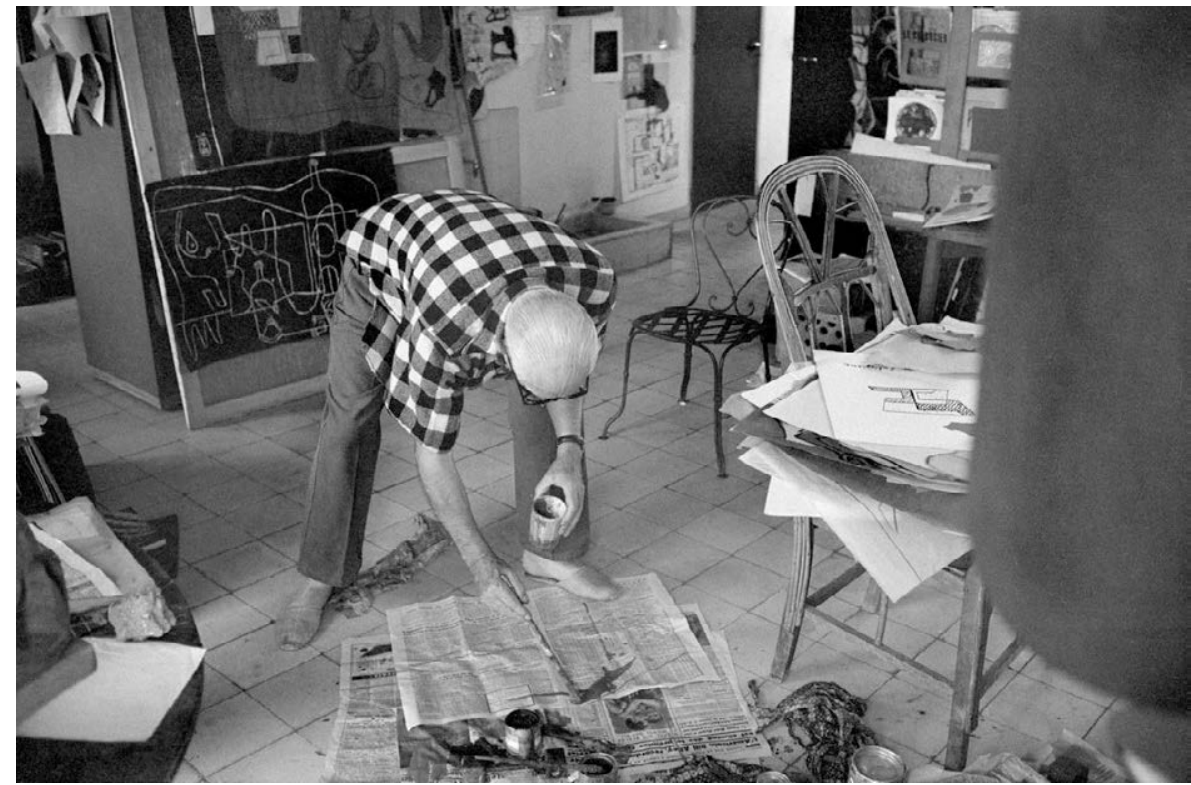

Descansar extenderse dormir

\section{- morir}

La espalda en el suelo...

¡Pero me he puesto en pie!

Ya que tú estás erguido

hete ahí listo para actuar.

Erguido sobre el plano terrestre

de las cosas comprensibles

contraes con la naturaleza un

pacto de solidaridad: es el ángulo recto

De pie vertical ante la mar

hete ahí sobre tus piernas».

Le Poeme de L'angle Droit, 1953.

Le Corbusier

\section{El primer elemento}

El pavimento del suelo en la construcción tiene algo de permanencia. Gracias a los pavimentos y mosaicos de las villas romanas, que tantas veces era lo único que permanecía de ellas, fue posible su compresión y reconstrucción, tal y como nos enseñó el arqueólogo Rodolfo Lanciani (1845-1929).

Como afirma Robert Le Ricolais (1894-1977): «El orden de la construcción sigue el orden de la destrucción». El suelo, visto así, se presenta de la misma forma que lo hacía el gato de Cheshire de Alicia en el País de las Maravillas (1865), de Lewis Carroll (1832-1898). El gato se materializaba de la siguiente manera y con el siguiente orden: primero aparecía la sonrisa, después la boca, los bigotes, las orejas, el cuerpo y la cola; y luego ocurría ese proceso al revés, desaparecía la cola, el cuerpo, las orejas, los bigotes, la boca y quedaba la sonrisa suspendida en el aire.

Así ocurre, tantas veces, en el orden de construcción. Y el pavimento irremediablemente vinculado a la solera del edificio forma parte de aquello que primero se construye (suelo-muros-techo), pero también es el último y único elemento que permanece horizontal cuando todo se ha destruido (techo-muros-suelo).
Figura 13.

A partment of Le Corbusier, 24

rue nungesser-et-Coli, 16th arrodissement, París (1931-

1934). Le Corbusier Fuller.

[Fotografía: CR ene Burri, 1960

CMagnum Photos. PAR 163159]
Pavimentos for en el pueblo de Frigiliana, Málaga (2018) [Fotografía: ㄷ] FGS
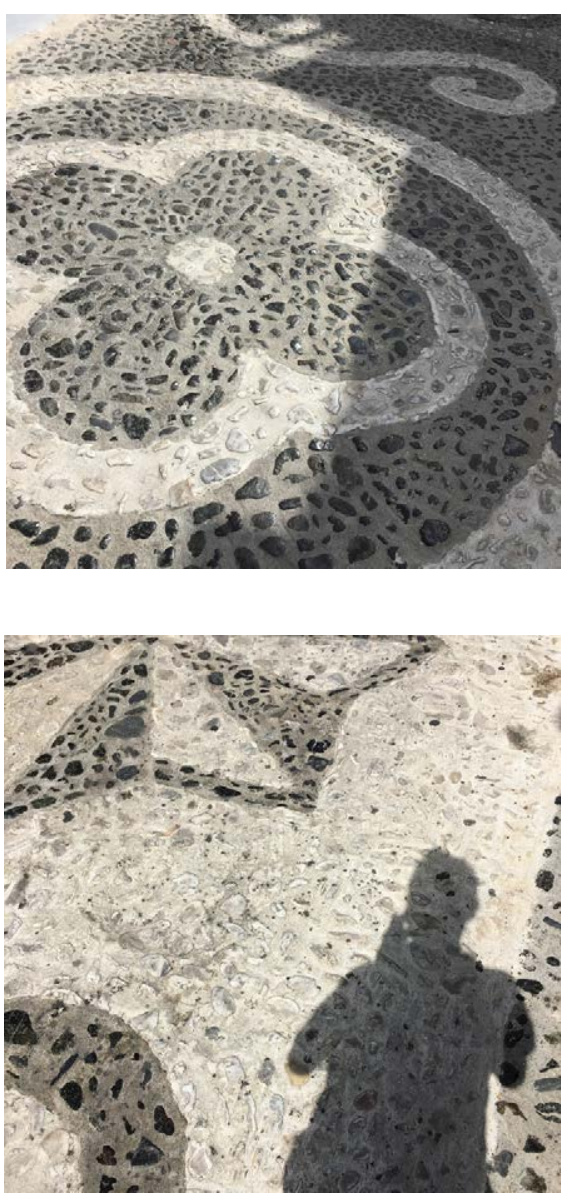
Pavimentos: huellas fenomenológicas, registros arqueológicos y planos de referencia

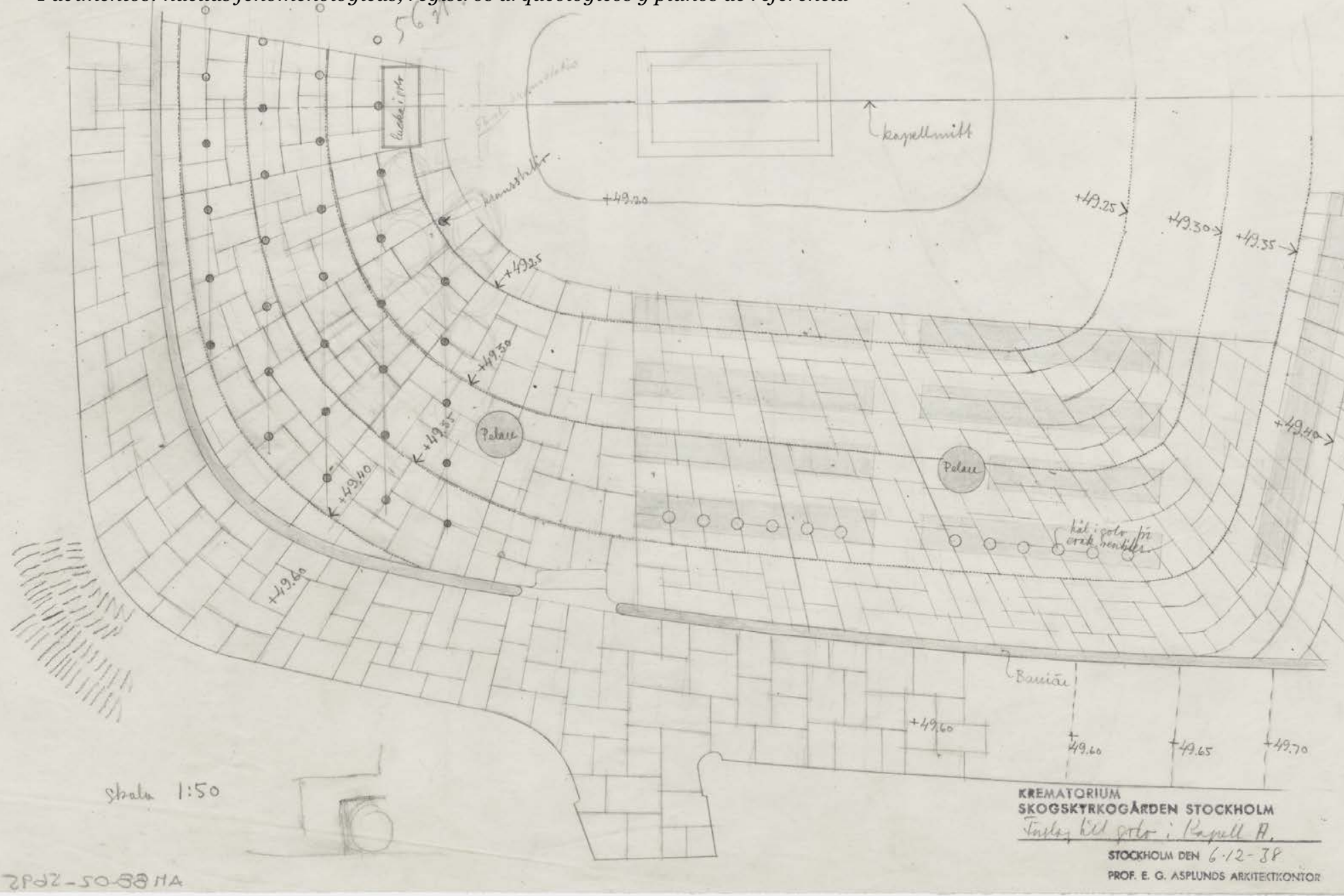

Figura 15

Dibujo del pavimento de la

Capilla en el bosque del

Cementerio, Estocolmo, Suecia

(1938). Erik Gunnar Asplund.

[Fuente: CDigitalt Museum. Art

Council Norway

[12] Koolhaas, Rem (ed.) y Easterling, Keller. «Floor». En: Elements of architecture. The Venice Biennale. 14th International Architecture Exhibition. Venezia: Marsilio Editori, 2014. p. 6.

[13] Latour, Bruno. We have never been modern. Cambridge, Massachusetts: Harvard University Press, 1993.

[14] Koolhaas, Rem (ed.) y Easterling, Keller. «Floor». Op. Cit. pp. 6-7.

[15] Molina-Rodríguez, Santiago de. «La arquitectura está por los suelos». Múltiples estrategias. Madrid: Ediciones asimétricas, 2015.

[https:// www.santiagodemolina.com/ 2015/ 01/laarquitectura-esta-por-los-suelos.html].

[16] Koolhaas, Rem (ed.) y Easterling, Keller. «Floor». Op. Cit. pp. 63-64.

[17] Ibíd. p. 64.
El suelo ha sido considerado, tantas veces, como el actor secundario e inerte frente a lo vertical, y ese aspecto le ha permitido ser, en cierto modo, libre e indisciplinado. Es el lugar donde se satisfacen los deseos más primarios [12], donde se manifiestan los impulsos más primitivos y donde se rememoran los atavismos más remotos.

Quizá, los maestros del Movimiento Moderno encontraron en los pavimentos un elemento que les permitía seguir formando parte de la tradición, a la que intentaron destruir con cualquiera del resto de los elementos que forman la arquitectura, como las puertas, las ventanas, o las fachadas. Algunos de ellos - de los maestros- encontraron en la atemporalidad y el romanticismo de los pavimentos populares, un cimiento cultural sobre el que posar su mirada y donde poder desarrollar una línea de investigación proyectual. Como señala Bruno Latour (1947-), quizá se trate de un elemento para el hombre 'no moderno' [13] que se escapa a las lógicas dominantes de la vida moderna [14].

\section{Superficie}

En el libro Hypnerotomachia Poliphili (Sueño de Polifilo) (1499) de Francesco Colonna (1433-1527) se describe la residencia de la reina Eleuterylida. El autor dedica páginas completas a describir los suelos repletos de jaspe, de cuarzo verde, de calcedonias, de ágatas... como prados en flor [15].

El suelo es depositario de las impurezas y de la suciedad, pero también deslumbra a los demás cuando se presenta con lustre y con brillo. Debido a su continuidad con la tierra natural y a que cualquier sustancia o materia puede depositarse sobre él -independientemente de si su estado es sólido o líquido, o su composición - el suelo se ha considerado siempre como algo sucio e indómito, 
y quizá por ello, se ha tratado de mantener obsesivamente no sólo limpio de impurezas, sino además se ha fregado insistentemente, algo que le otorgara un brillo y un aroma extra. Pero también al pavimento se ha tratado con un grado de mantenimiento más enérgico y continuo en el tiempo - mediante el pulido o abrillantado periódico- que el resto de elementos arquitectónicos. En el siglo XVIII, los suelos de madera se limpiaban con arena y las alfombras se golpeaban para eliminar el polvo.

Durante el siglo XX, el pavimento se ha convertido en un campo de pruebas de los investigadores hacia la búsqueda de métodos de tratamiento superficial para cada material, que ayudaran a mantener el brillo o evitaran la aparición de manchas [16]. 0 al desarrollo de nuevas patentes de suelos artificiales que competían con la piedra natural, o intentaban imitarla.

Al igual que ocurre en otros ámbitos, son las necesidades militares las que también han ayudado al desarrollo de los pavimentos y superficies para que tuvieran mayor resistencia al deslizamiento aminorando la resbaladicidad. Y esas necesidades militares también han investigado y desarrollado suelos a prueba por su durabilidad.

Las superficies horizontales, por ser donde los cuerpos se precipitan cuando pierden el equilibrio, son también los elementos arquitectónicos que con más frecuencia son objeto de litigios [17] - a veces en las arquitecturas privadas, pero sobre todo en las públicas y en el espacio urbano.

Los pavimentos, como materia que son y como arquitectura de contacto que son, son sensibles al desgaste. A Francisco de Goya (1746-1828) se le atribuye

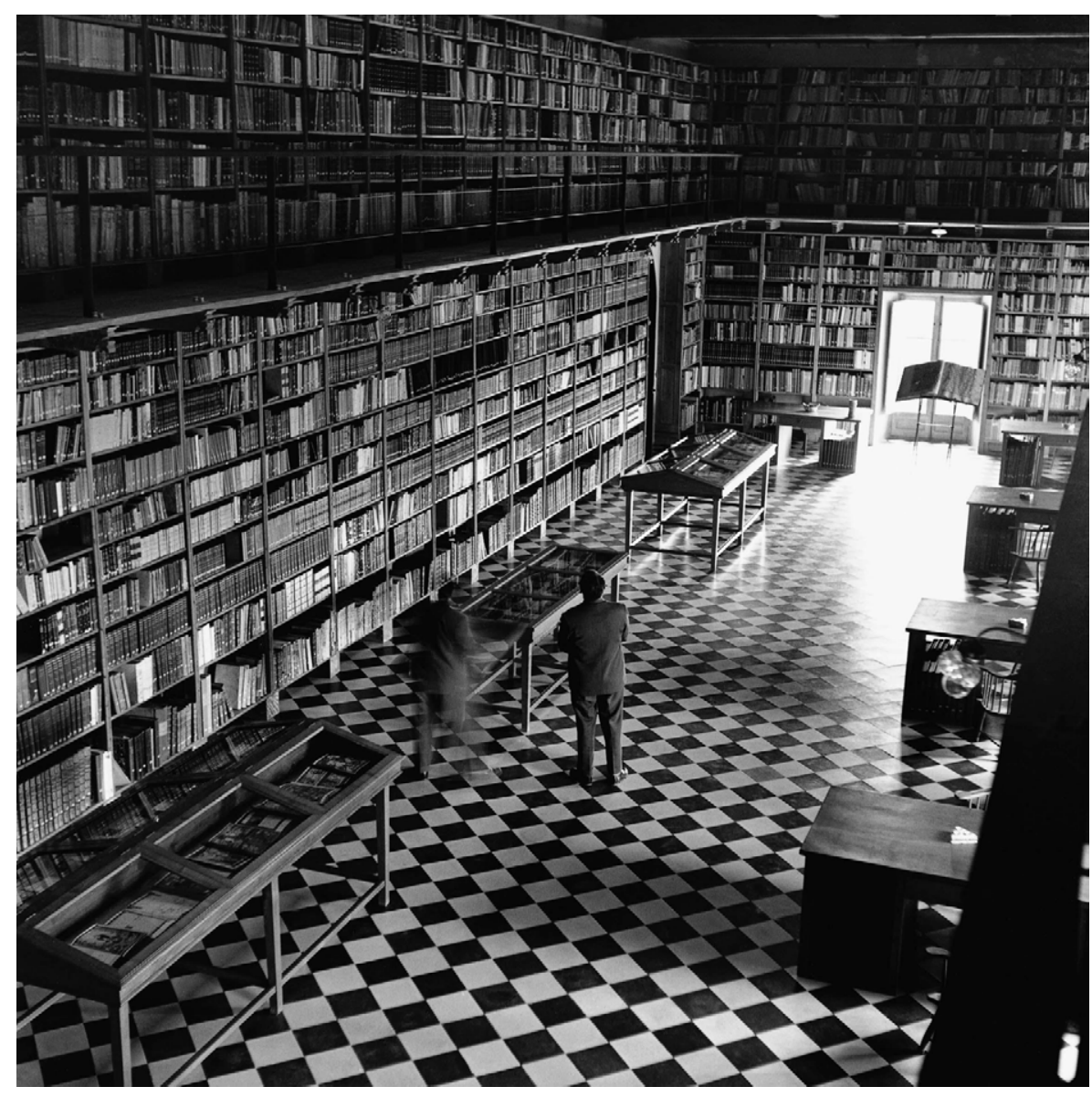

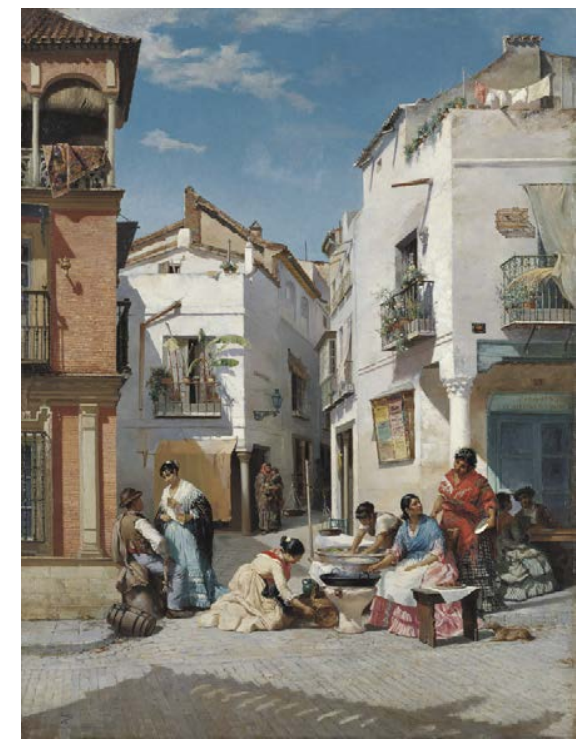

Figura 16. Vendedoras de rosquillas en un rincón de Sevilla (1881). Manuel Wssel de Guimbarda. [Fuente: (M) Museo Carmen Thyssen de Málaga. CTB.1987.29]

Figura 17.

Biblioteca del Castillo de Peralada (c1950). [Fotografía: CF rancesc Català-Roca CMNCARS. Museo Nacional Centro de Arte Reina Sofía, Madrid. AD03477] 


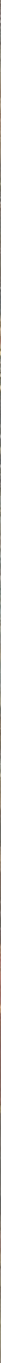

Figura 18.

Penitentes en la Basílica inferior de Asís (1874). J osé

Iiménez Aranda. [Fuente:

CMuseo Nacional del Prado de Madrid. P007777]
[18] Citar a Moneo sobre el libro "la vida de los edificios".

[19] Koolhaas, Rem (ed.) y Easterling, Keller. «Floor». En: Elements of architecture. The Venice Biennale. 14th International Architecture Exhibition. Venezia: Marsilio Editori, 2014. p. 60.

[20] Ruby, Ilka y Ruby, Andreas. «Suelo inscrito». En: Groundscapes. El reencuentro con el suelo en la arquitectura contemporánea. The rediscovery of the ground in contemoprany architecture. Barcelona: Editorial Gustavo Gili, 2005. P. 181.

[21] Ibíd. la cita de que 'el tiempo también pinta', pero el paso del tiempo también construye. El suelo recibe con gusto los rastros y las huellas fruto de su uso: el desgaste de su brillo, los surcos que el agua ha registrado sobre su superficie, los alabeos como consecuencia de la inestabilidad del piso sobre el que se asienta - bien sean cóncavos, bien sean convexos-, los descalces de algunas de sus piezas o las imperfecciones como consecuencia de la desligazón de sus partes. Pero también los cambios de tonalidad, de rugosidad o su nivel de pulido, las esquirlas perdidas o incluso las sustituciones de piezas por otras de otro tipo, nos recuerda que los pavimentos, al fin y al cabo, son una obra humana. Su evolución a lo largo del tiempo, como ocurre con las obras de arquitectura, no siempre es obra del autor. Los suelos, como los edificios, disfrutan de una vida propia [18] que ya les pertenece.

Algunos de los maestros del Movimiento Moderno - Dimitris Pikionis, Gio Ponti, Alison y Peter S mithson, Erik Gunnar Asplund o Alvar Aalto, entre otros- como veremos más adelante, intentarán en sus obras que el tiempo se manifieste en la imperfección de sus pavimentos.

Algunos de los primeros intentos de tratamientos superficiales de las piezas de pavimento no se diferencian mucho de las técnicas contemporáneas. Así, los suelos de los baños en el antiguo pueblo Sumerio (c2800-2200 a.C.) se fabricaban con ladrillos cocidos revestidos de material bituminoso e impregnados con piedra caliza pulverizada. El agua se drenaba por canales revestidos de azulejos [19].

\section{La querencia de lo visual}

«Suelo Inscrito. Desde una perspectiva clásica, la arquitectura ha desempeñado su función semiótica de transportar imágenes y textos en las superficies verticales de sus fachadas. Con la conquista del espacio 
aéreo por parte de los rascacielos y los aviones, la cubierta se convirtió en la 'quinta fachada' y en un posible portador de signos. Más tarde, la visión del arquitecto se alejó de la cubierta, extendiéndose hasta las superficies horizontales del terreno, que enmarcan el edificio. En analogía con el plano que está sobre la mesa de dibujo, el suelo es programado como el lienzo para una imagen que sólo a vista de pájaro puede abarcarse visualmente como conjunto. Sin embargo, la función del suelo no consiste tanto en ser visto como en crear espacio. Como usuarios terrenales de esta imagen inscrita en el terreno, percibimos sus estructuras de un modo más bien sensorial, recorriendo su superficie como hormigas e intentando comprender su significado mediante el tacto. La inscripción de la imagen en el suelo traduce la constelación gráfica de la imagen a un relieve topográfico y transforma los puntos, las líneas y las superficies de la imagen en elementos programático de un espacio en el que apenas se reconoce ya su origen icónico» [20].

La querencia sobre lo visual - especialmente exagerada en el siglo XX con la aparición de la fotografía - ha llevado a los arquitectos, diseñadores y creadores $-\mathrm{y}$ a los usuarios - a centrarse en el plano vertical, como el elemento donde depositar el ingenio creativo, la composición o la representación. Incluso, la arquitectura ha desempeñado su función semiótica de transportar imágenes, códigos y textos sobre las superficies verticales de sus fachadas [21].

Sin embargo, de todos los documentos gráficos que maneja un arquitecto, es el del plano del suelo en general - la planta- , y el del pavimento en particular, sobre el que se establece una mayor analogía entre la posición del papel sobre la mesa o el tablero de dibujo y la realidad construida sobre un plano horizontal.

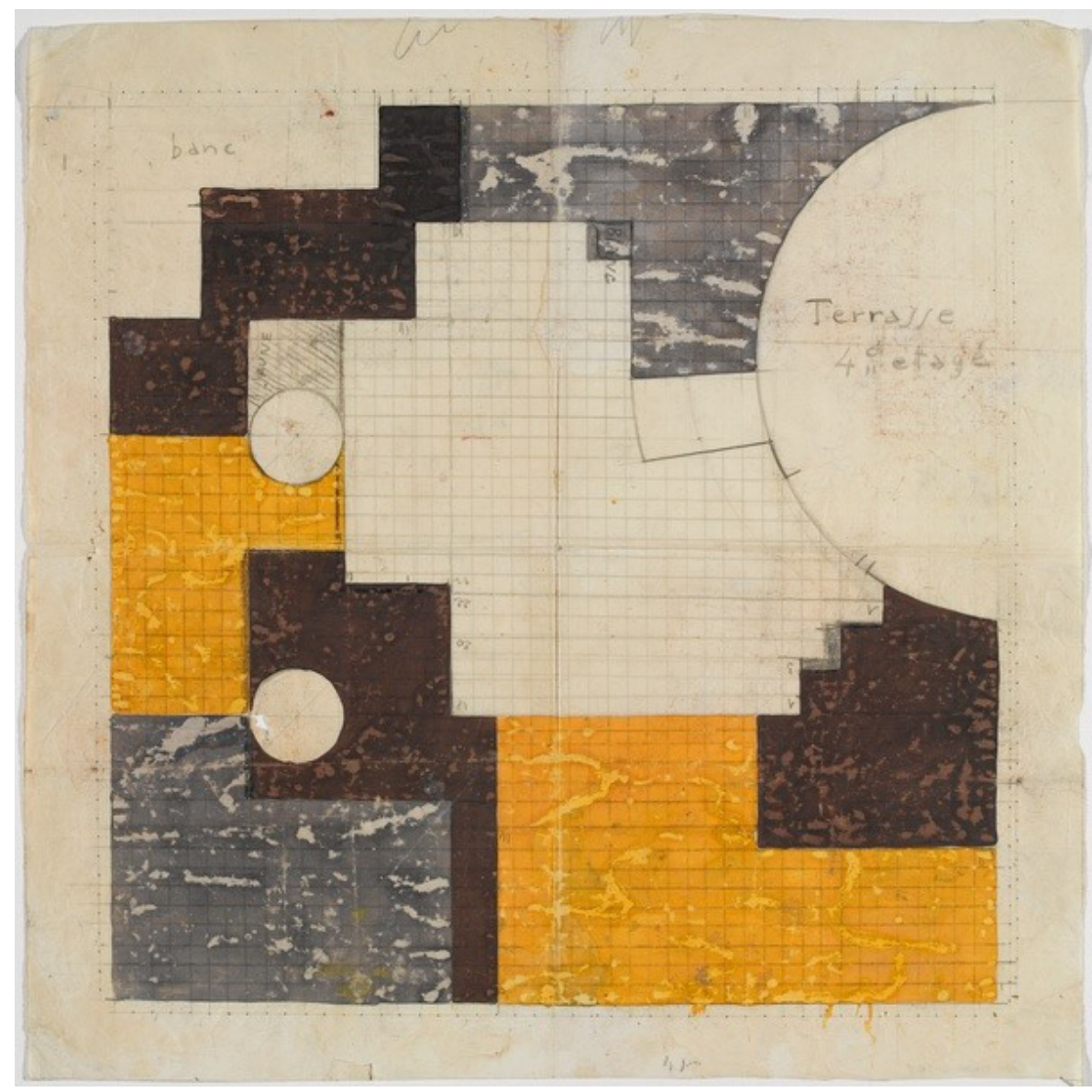

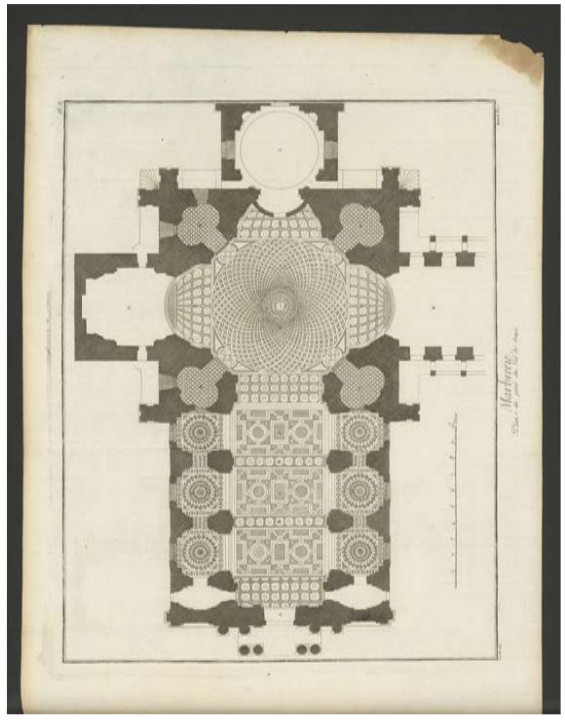

Figura 19

L'Encyclopèdie ou dictionnaire raissoné des sciences, des arts et des métiers sous la direction de Direrot et d'Alembert, tome 5 (c1526). [Fuente: CP hoto RMN F $\mathrm{R}$ (C) harenton-le-Pont Médiathèque de l'Architecture et du Patrimoine

Figura 20.

Dibujos de pavimentos (SF)

J oel Martel. [Fuente: (C) oel

Martel]
Figura 21 Dibujos de pavimentos (SF) J oel Martel. [Fuente: (C) oe Martel]

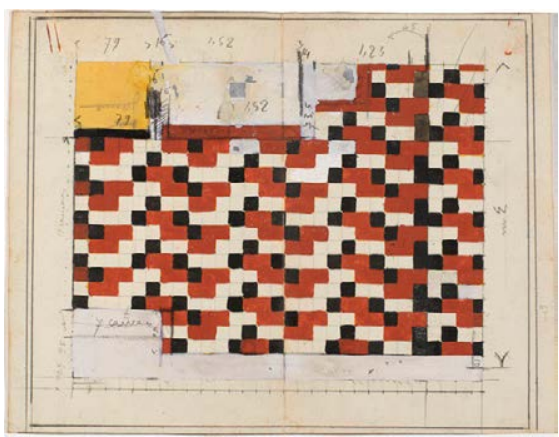




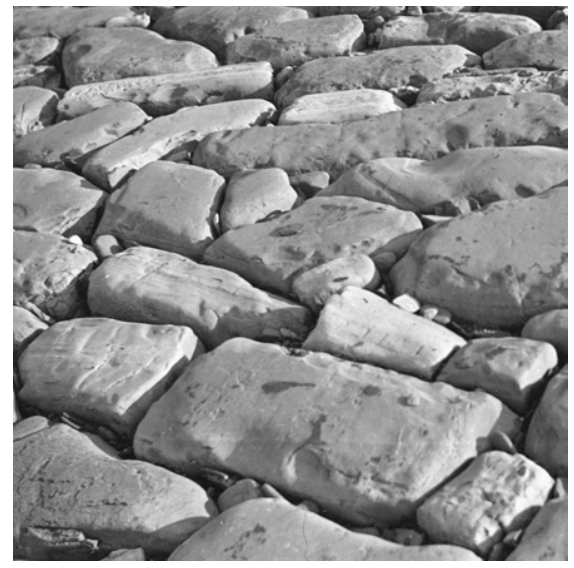

Figura 22.

Black and white negative, a

stone beach (SF). J ohn Nash.

[Fuente: CTATE, Londres. TGA

7050P H/942]
Figura 23. Planta de pavimentos de la Casa de vacaciones del Dr. Fernando Ribeiro da Silva (Casa de Ofir), Ofir, Fâo, Portugal (1957-1958). Fernando Távora. [Fuente: of undación Fernando Távora]

[22] Le Corbusier (J eanneret, Charles-Édouard). Vers une architecture. París: Saugnier, 1923. Hacia una arquitectura. Barcelona: Ed. Apóstrofe, 1998.

[23] Koolhaas, Rem (ed.) y Easterling, Keller.

«Floor». En: Elements of architecture. The Venice Biennale. 14th International Architecture Exhibition. Venezia: Marsilio Editori, 2014. p. 22.

[24] Koolhaas, Rem. Delirious New York. New York: Oxford University Press, 1978.

Koolhaas, Rem. Delirio de Nueva York. Barcelona: Gustavo Gili, 2004.

[25] Koolhaas, Rem (ed.) y Easterling, Keller. op. Cit. pp. 39-40

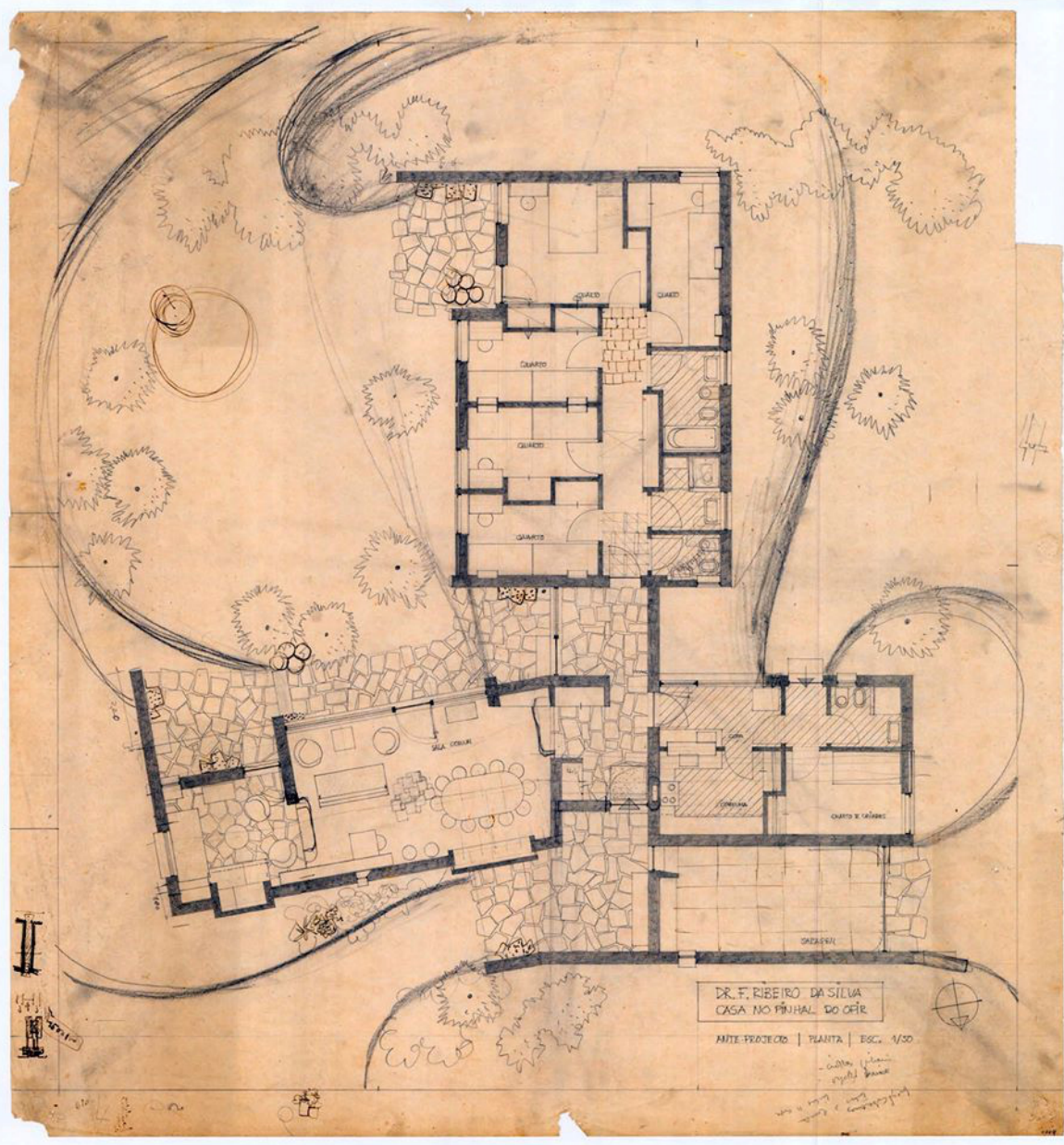

Charles-É douard J eanneret-G ris, Le Corbusier (1887-1965), su libro Vers une Architecture (1923) defiende la 'planta' como generadora de espacio:

«La planta es el generador. Sin planta, sólo hay desorden y arbitrariedad. La planta lleva en sí la esencia de la sensación.

La planta está en la base. Sin planta, no hay grandeza de intención y de expresión, ni ritmo, ni volumen, ni coherencia. Sin planta, se produce esa sensación de informidad, de indigencia, de desorden, de arbitrariedad, insoportalbe al hombre.

La planta necesita la imaginación más activa. también necesita la disciplina más severa. La planta es la determinación del todo» [22].

Si durante toda la historia, ha sido la orografía sobre la que se asentaban los pueblos - sobre cotas elevadas - o las torres de los Templos, los responsables que han permitido disfrutar de vistas cenitales, ha sido durante el siglo XX, cuando la conquista del espacio aéreo ha permitido, desde los dirigibles (zeppelin), los aviones o los satélites - o gracias a la construcción de los edificios altospoder contemplar la superficie del suelo desde una cierta distancia vertical. También han posibilitado registrar documentalmente mediante fotografía nuestro suelo horizontal, en parte, por motivaciones militares.

Así, las cubiertas de los edificios, la 'quinta fachada' enunciada por CharlesÉ douard J eanneret-Gris, Le Corbusier (1887-1965) en su manifiesto, pudo convertirse en una portadora de signos, que se extendió hasta las trazas del territorio modificado por el hombre. Pero si bien la primera función del suelo nunca 
fue ser visto cenitalmente, lo cierto es que la cultura moderna de la imagen ha encontrado en las trazas de los pavimentos un espacio donde depositar el ingenio creativo a través de el dibujo, la pintura o la fotografía que captaran los mosaicos, las representaciones figurativas 0 abstractas, las historias gráficas 0 los patrones elaborados formando teselaciones. A lo largo de la historia, los constructores y los arquitectos, al igual que los artistas en el arte, se han entretenido en estudiar cómo rellenar una superficie. El teselado, es decir, el modo de cubrir una superficie con figuras que no se superponen y no dejan huecos entre sí, y donde se pueden establecer leyes de regularidad o patrones de repetición.

\section{El pavimento como campo de intercambio comercial}

Aunque fue Francisco de Quevedo (1580-1645) quien se la dijo al Duque de Osuna en 1611, fue Antonio Machado (1875-1939) quién popularizó la cita y la incluyó en sus Proverbios y cantares (LXVIII): «Todo necio confunde valor y precio». El área, y no el volumen, determina el precio - aunque no siempre el valor- de las propiedades y construcciones en los intercambios comerciales entre semejantes. Por lo tanto, la medida del suelo o la superficie del pavimento, forman parte de las primeras incógnitas a conocer cuando la arquitectura se convierte en un objeto de consumo. La forma de medir el suelo mediante el paso romano (passus) o el pie - ligado formalmente a la planta del pie- ya señalan la querencia cultural atávica de cuantificar el espacio con la dimensión de su superficie [23].

El rascacielos moderno surge de la combinación del ascensor y de las estructuras de acero. Los primeros proliferaron en Chicago y New York. Rem Koolhaas reprodujo en el libro Delirious New York (1978) [24] una caricatura aparecida en la revista Life en 1909. En ella puede verse una serie de bandejas horizontales, una infraestructura que es capaz de albergar distintos programas y que multiplica infinitas veces la superficie de suelo sobre la que se apoya. En ese libro también incluye una sección del 'New York Athletic Club' (buscar año y arquitecto) que incluía un campo de golf en el piso 7, una piscina en el piso 120 un jardín en el piso 17, además de alojamientos residenciales [25].

La 'Maison Dom-Ino' (1914) de Charles-É douard J eanneret-Gris, Le Corbusier (1887-1965) pretendía abordar la escasez de viviendas en los albores de la I Guerra Mundial (Gran Guerra). Disponía de una planta libre, donde los pilares y el cerramiento eran estructuralmente independientes. Cada una de las losas era una plataforma sobre la que además se apoyaba las particiones interiores.

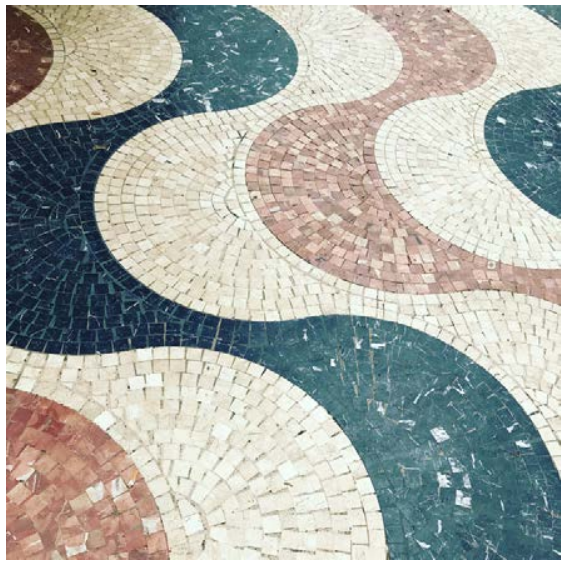

Figura 24 Pavimento del Paseo de Alicante en la Avenida Conde de Vallellano (SF). [Fotografía: (C) FGS, 2018]

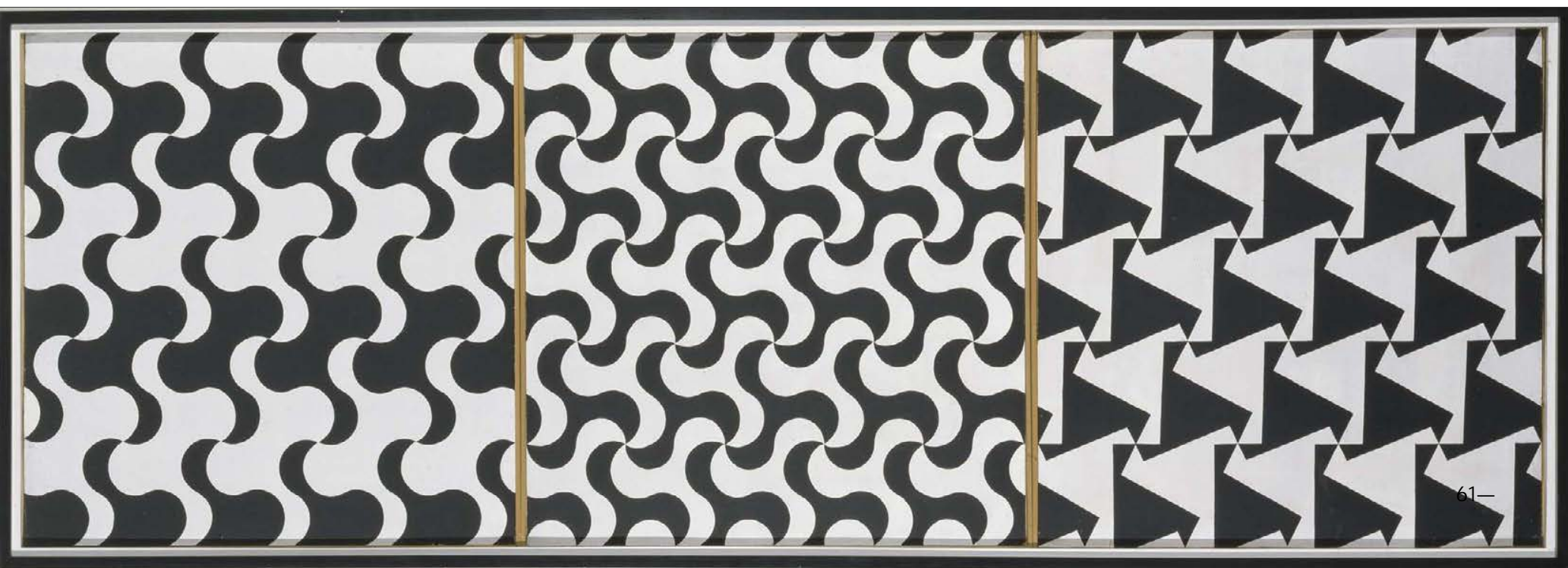




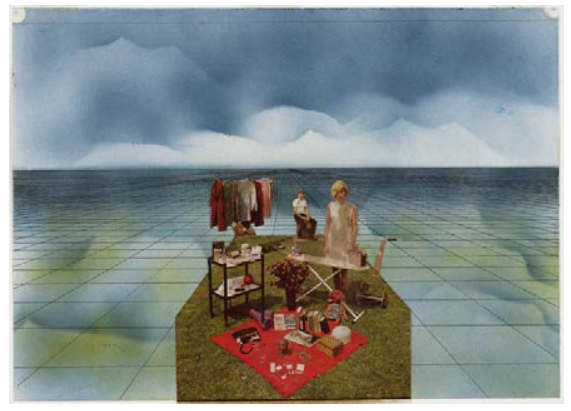

Figura 26.

Supersurface, The Happy Island (1971). Superstudio. [Fuente: CMoMA. Museo de Arte Moderno de New York. 1254.1974]

Figura 27 The Continuous Monument: Alpline Lakes, project (1969). Superstudio. [Fuente: OMoMA. Museo de Arte Moderno de New York. 1312.2000]

[26] Koolhaas, Rem (ed.) y Easterling, Keller. «Floor». En: Elements of architecture. The Venice Biennale. 14th International Architecture Exhibition. Venezia: Marsilio Editori, 2014. pp. 144-145.

[27] Ibíd. p. 145.

[28] Ibíd.

[29] Campomaggi, J ulia. «DOMUS, 1948-1978. La conformación del espacio interior doméstico a través del mobiliario». Director: Xavier Monteys Roig Barcelona: Universitat Politècnica de Catalunya, Escola Tècnica Superior d'Arquitectura, Departament de Projectes Arquitectònics, 2015.

[30] Superstudio. «Superstudio: discorsi per immagini». Domus. Milán: Editoriale Domus, dicembre 1969, núm. 481, pp. 108-109.

[31] Koolhaas, Rem (ed.) y Easterling, Keller. Op. Cit. p. 145.

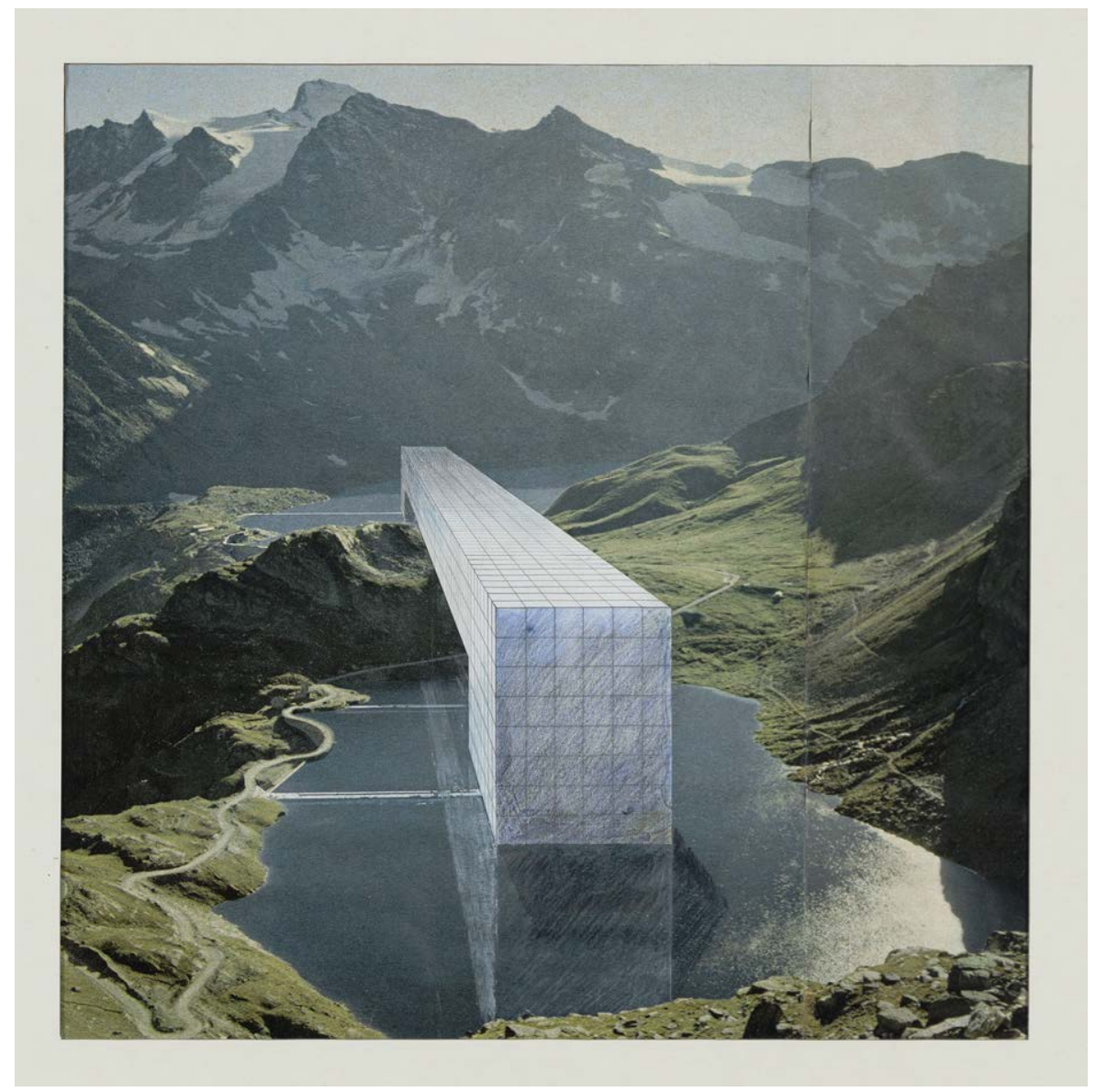

En la década de 1960, tanto Archizoom como Superstudio - dos grupos de arquitectos de la contracultura - presentaron el suelo como una crítica exagerada hacia la ubicuidad del mercado [26]. Superstudio presentó 'Supersurface' (1972) en forma de película, con motivo de la exposición 'Italy: The New Domestic Landscape / Italia: el nuevo paisaje doméstico' en el MoMA en 1972 y comisariada por Emilio Ambasz. Y donde estaba incluido el proyecto 'Monumento continuo' (1969). Se trataba de una superficie cuadriculada de una plataforma o infraestructura en el paisaje, donde el pavimento terminaba por modular también los alzados o las fachadas de las construcciones. El objeto, pintado de color blanco, se proponía colonizar el planeta por los «límites narrativos de los territorios políticos» [27]. Era un urbanismo de otra soberanía, un espacio abstracto del Capital que envolvía a las ciudades como si fueran reliquias de otro tiempo [28]. Y que representaba el retorno a una realidad política y económica como modo de recuperar el medio ambiente. Se trataba, de algún modo, de una tábula rasa.

La exposición 'Architecture and Freedom' celebrada en Graz el 4 de octubre de 1969 durante la bienal Trigon, en la que participaron Austria, Yugoslavia e Italia. Las bases especificaron que los participantes tenían que definir el grado de libertad que en un futuro se le podría otorgar al individuo y a la sociedad en el ámbito de la arquitectura del futuro y las limitaciones que ésta debería imponer a esos grados de libertad. Se trataba más de proponer espacios activos que reflexionaran sobre el espacio arquitectónicos-y no happenings-Superstudio propuso 'La stanza di Graz': un objeto autónomo y artificial, no pensado para ser exhibido, sino como un objeto con cierta autonomía. Se trataba de un espacio con tres accesos sobre un pavimento inclinado unos $12^{\circ}$ de color verde. Un rectángulo de $1,8 \times 2,4 \mathrm{~m}$ y de $6 \mathrm{~m}$ de altura que permite ser atravesado por el 
suelo [29]. El objeto, la habitación, está revestido en su exterior e interior por una superficie plástica de color blanco que dispone de una retícula de líneas negras de $5 \times 5 \mathrm{~cm}$. Según los propios arquitectos, se trataba de «un espacio para la meditación sobre la medida» [30].

El proyecto de Archizoom 'Non-S top City' (1969) presenta un suelo infinito y cuadriculado cubierto por un techo. Un espacio sin interrupciones, acondicionado y mercantilizado, como si fuera una planta de oficinas o un supermercado [31]. Como veremos en el Capítulo 11: «El pavimento preciso. El suelo como plano de referencia» en las obras de Mies van der Rohe (1886-1969) las trazas del pavimento terminan por dictar la posición de la estructura, de los cerramientos de vidrio y hasta del ajuar doméstico.
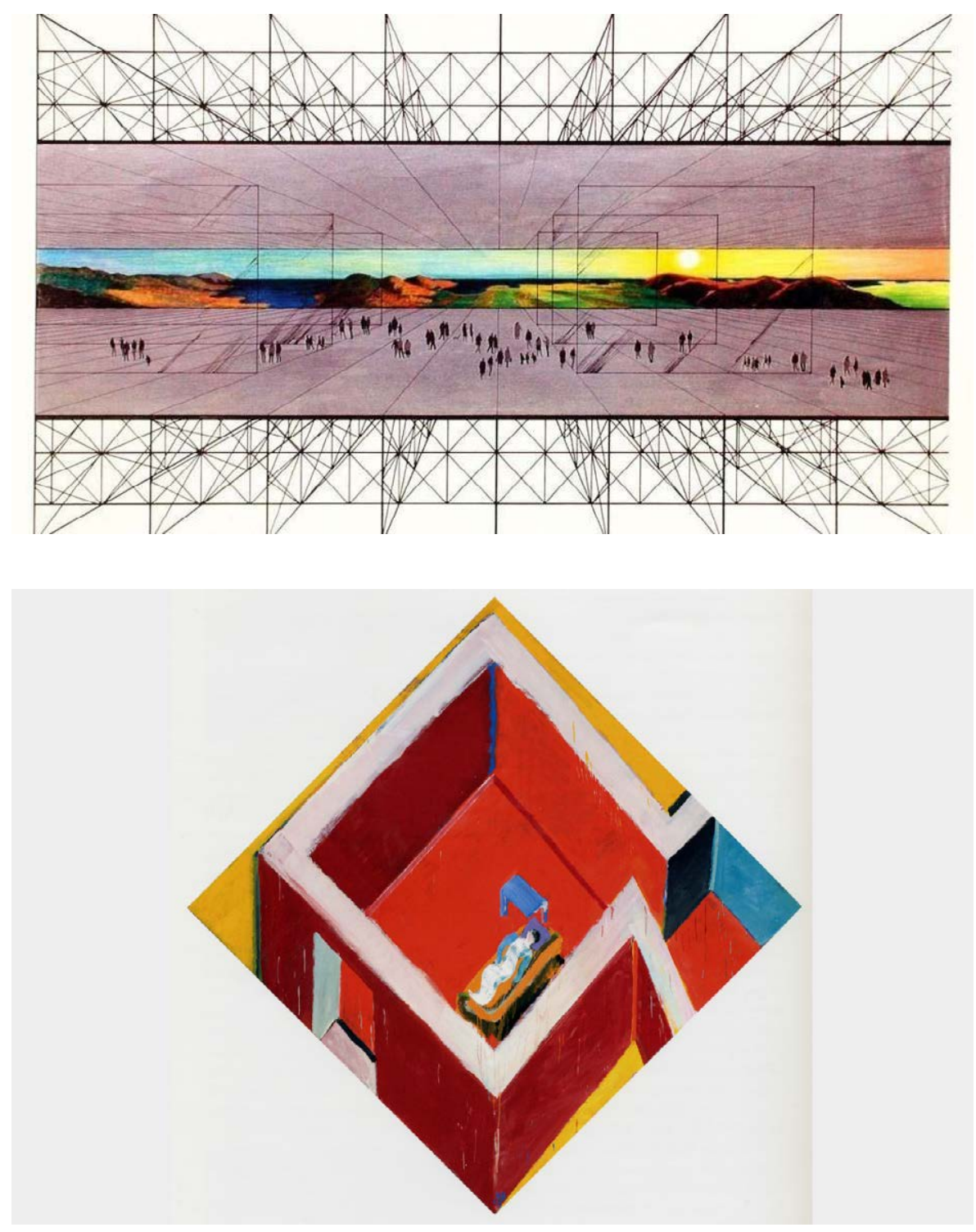

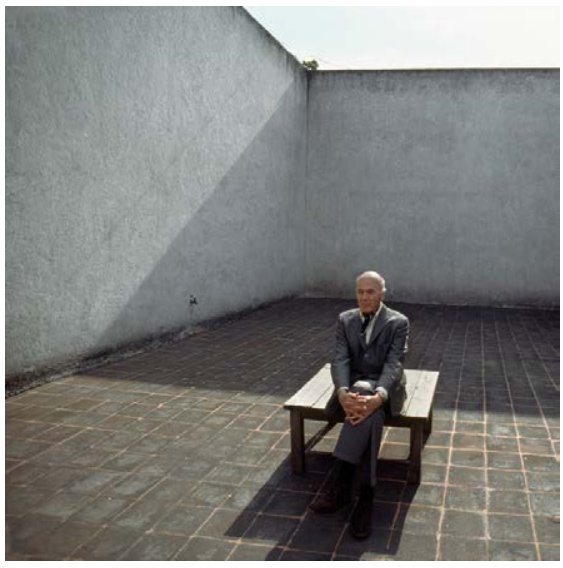

Figura 28.

Luis Barragán sentado en una terraza pavimentada (1976) [Fotografía: ORene Burri OMagnum Photos. PAR 368452]

Figura 29.

Non-S top-City (1969)

Archizoom. [Fuente: OSF]

Figura 30.

Habitación roja con figura (2005). J uan Navarro

Baldeweg. [Fuente: (C) uan Navarro Baldeweg] 


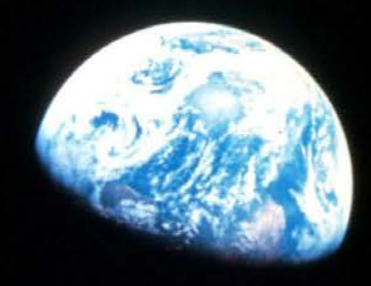


CAPÍTULO 2

\section{El suelo cósmico El pavimento y la escala}

\section{Introducción}

En el cuadro conocido como Pala Brera / Virgen con el Niño y Santos (c14651470) del pintor renacentista Piero della Francesca (1416-1492) se representa el tema de la 'Conversación Sagrada': la Virgen entronizada y situada en el centro sostiene al Niño dormido en su regazo. Lo hace sin ayuda de las manos que, paradójicamente las une para rezar, mientras en Niño, decididamente sobredimensionado, yace sobre sus rodillas a expensas de la gravedad. La Virgen, ligeramente sobre-elevada del liso pavimento sobre un estrado cubierto con una alfombra roja, está rodeada de San J uan bautista, San Bernardino, San J erónimo - golpeándose con una piedra en el pecho- , San Francisco, San Pedro Mártir y los arcángeles, todos ellos descalzos. Y, en primer plano y arrodillado, a Federico de Montefeltro, quien además desequilibra la simetría exacta de la escena, tanto por el número de personajes como por su género. La escena se desarrolla en un espacio arquitectónico también simétrico: un ábside coronado por una forma de vénera (concha de almeja) de la que pende un huevo de un hilo coincidente, otra vez, con el eje de simetría.

Pareciera que el huevo, unido al hilo, fuera una primitiva plomada que, todavía hoy, desvela la vertical exacta en el proceso constructivo. Independientemente de otras consideraciones, el misterioso huevo nos insiste en la irrenunciable fuerza de la gravedad, aquella que obedece la llamada de la Tierra y del suelo. Aquella que hace que los Hombres y las cosas permanezcan unidos definitivamente a él. Y es ese huevo quien nos recuerda que el Niño, en cualquier momento, puede caerse del regazo de la Virgen. Por tanto, tenemos el elemento vertical representado por el hilo con el huevo, que insiste en el tema de la gravedad, y el elemento horizontal del plano del pavimento [1].
Figura 0. Página anterior Apollo 8 mission (24 de diciembre de 1968). William Alison Anders. [Fuente: CNASA. AS 08-14-2383]
[1] Ramírez-Domínguez, Juan-Antonio. «Pavimento, suelo, tierra (de promisión)». En: Fernández Polanco, Aurora (ed.). Cuerpo y mirada, huella del siglo XX. Madrid: Museo Nacional Centro de Arte Reina Sofía, 2007. pp. 65-87. 
Figura 1. Pala Brera / Virgen con el Niño
y Santos (c1465-1470). Piero y Santos (c1465-1470). Piero della Francesca. [Fuente:

Figura 2.

La columna y el peso (1973). J uan Navarro Baldeweg.

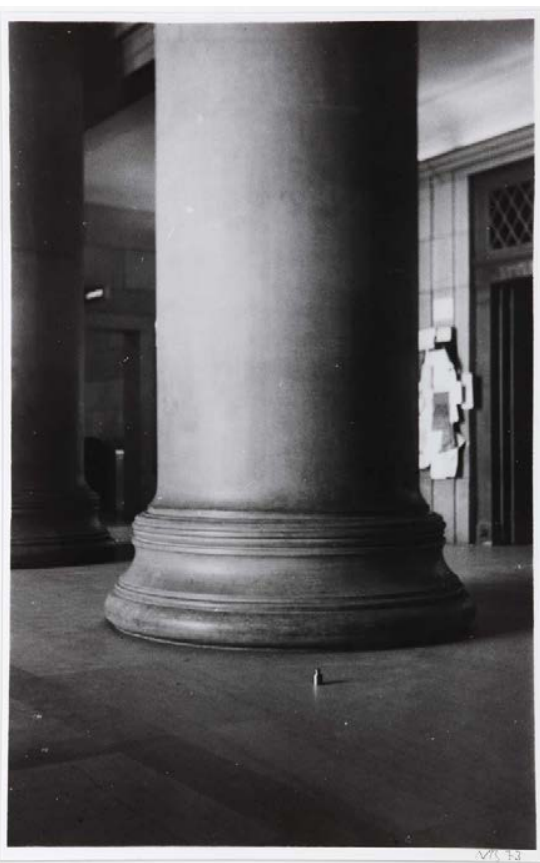

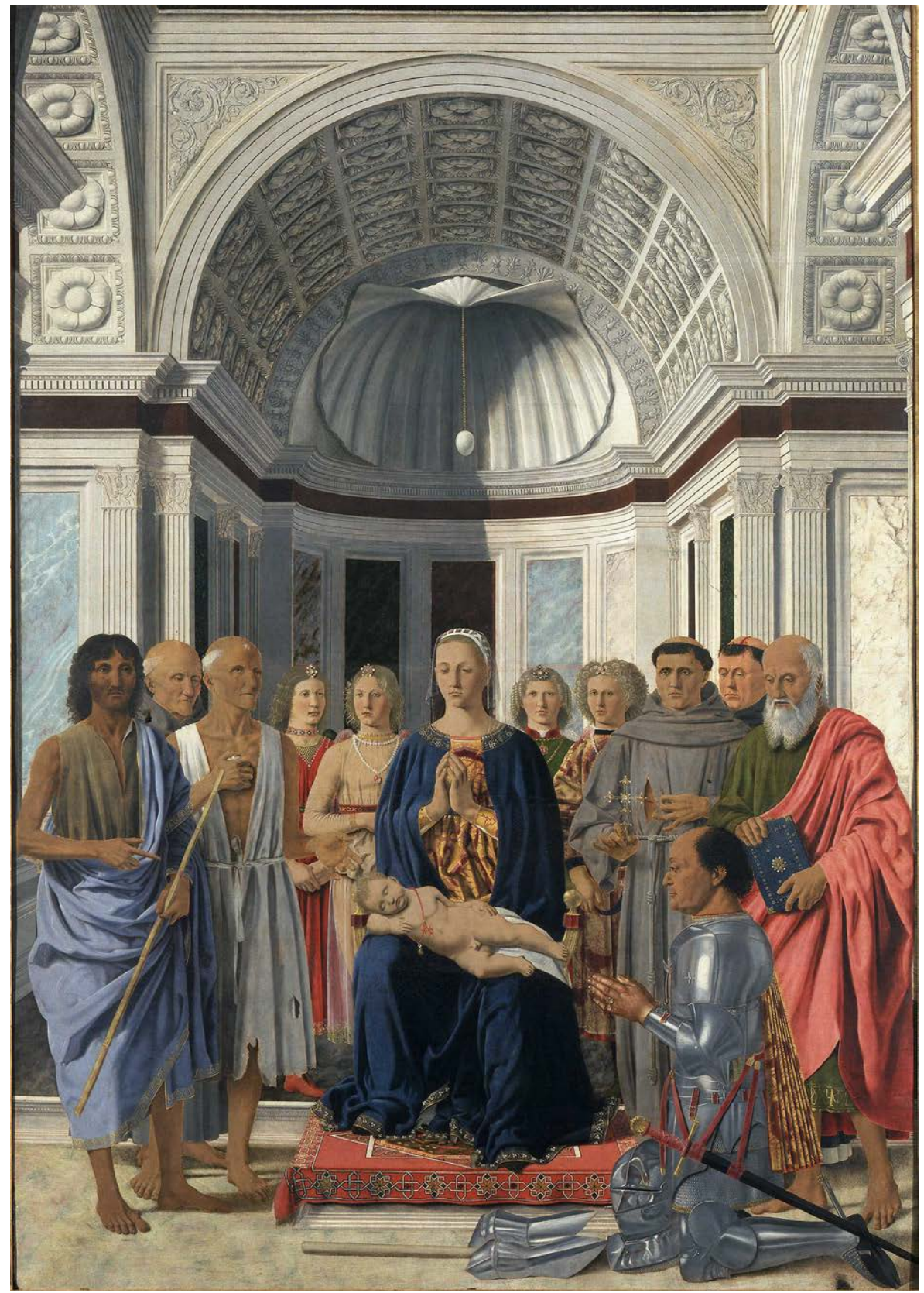

«Mira ese punto. Eso es aquí. Eso es nuestro hogar. Eso somos nosotros. Ahí ha vivido todo aquel de quien hayas oído hablar alguna vez, todos los seres humanos que han existido. La suma de todas nuestras alegrías y sufrimientos. Cada héroe y cada cobarde. Cada rey y cada campesino...»[2].

Estas fueron las palabras del divulgador Carl Sagan (1934-1996) al ver la fotografía de la Tierra tomada en 1990 por la sonda espacial Voyager 1, a 6.000 millones de kilómetros. La imagen fue bautizada como 'The pale blue dot' (un punto de azul pálido). En la foto, la Tierra es una mota casi imperceptible en la inmensidad del universo. Ése es nuestro lecho. Ése es nuestro suelo.

Unos años antes, con el comienzo de los viajes tripulados al espacio llegaron las primeras fotos de la Tierra en color. El 24 de diciembre de 1968, la tripulación del Apollo 8 obtuvo la mítica imagen 'Earthrise' (salida de la Tierra) contemplada desde la órbita de la Luna, y con ésta en primer plano. Unos años des- 
pués, el 7 de diciembre de 1972, la tripulación del Apollo 17 tomó una de las más famosas, la conocida como 'Blue Marble' (la canica azul), ya que era la primera vez que se contemplaba la Tierra completamente iluminada a unos 45.000 kilómetros de distancia. La foto se la debemos, en parte, a Steward Brand, un joven discípulo del visionario R ichard Buckminster (Bucky) Fuller (1895-1983) que había lanzado una campaña pública para que la NASA publicase una imagen completa de la Tierra desde el espacio. Entre otros motivos, para ilustrar la portada del fanzine contracultural Whole Earth Catalog [3] y que en distintas ediciones se había conformado con una composición de fotografías de nuestro planeta obtenida por el satélite ATS-3 en 1967, con la Earthrise y finalmente la ansiada Blue Marble que ilustraría la edición de 1972. Entre el 18 de abril y el 23 de octubre de 2012 el satélite Suomi NPP se obtuvieron las imágenes necesarias para la composición de la conocida 'Black marble' (la canica negra), donde se podía ver una imagen de la Tierra iluminada por la noche. Entre ambas imágenes pasaron 40 largos años, y aproximadamente en el ecuador de ese periodo, el 7 de febrero de 1984, se capturó la escalofriante fotografía del astronauta Bruce McCandless flotando sin ataduras en el espacio - a 100 metros de distancia de la nave Challenger- y como fondo el orbe terráqueo y el negro infinito del Universo. Es difícil encontrar otro ejemplo donde el Hombre haya podido experimentar la soledad más inmisericorde. Hemos hablado de la etimología de la palabra suelo en la Introducción.

Volviendo a la fotografía de 1972, su nombre - la canica azul- ya señalaba que en nuestro entorno predomina lo líquido; y sin embargo, el hombre ha colonizado las zonas cálidas de la tierra firme, como nos transmite la imagen nocturna - la canica negra - Nuestro medio natural es sólido. Desde entonces, Blue marble no ha dejado de evocarnos misterios. Ésa es la «nave espacial Tie-

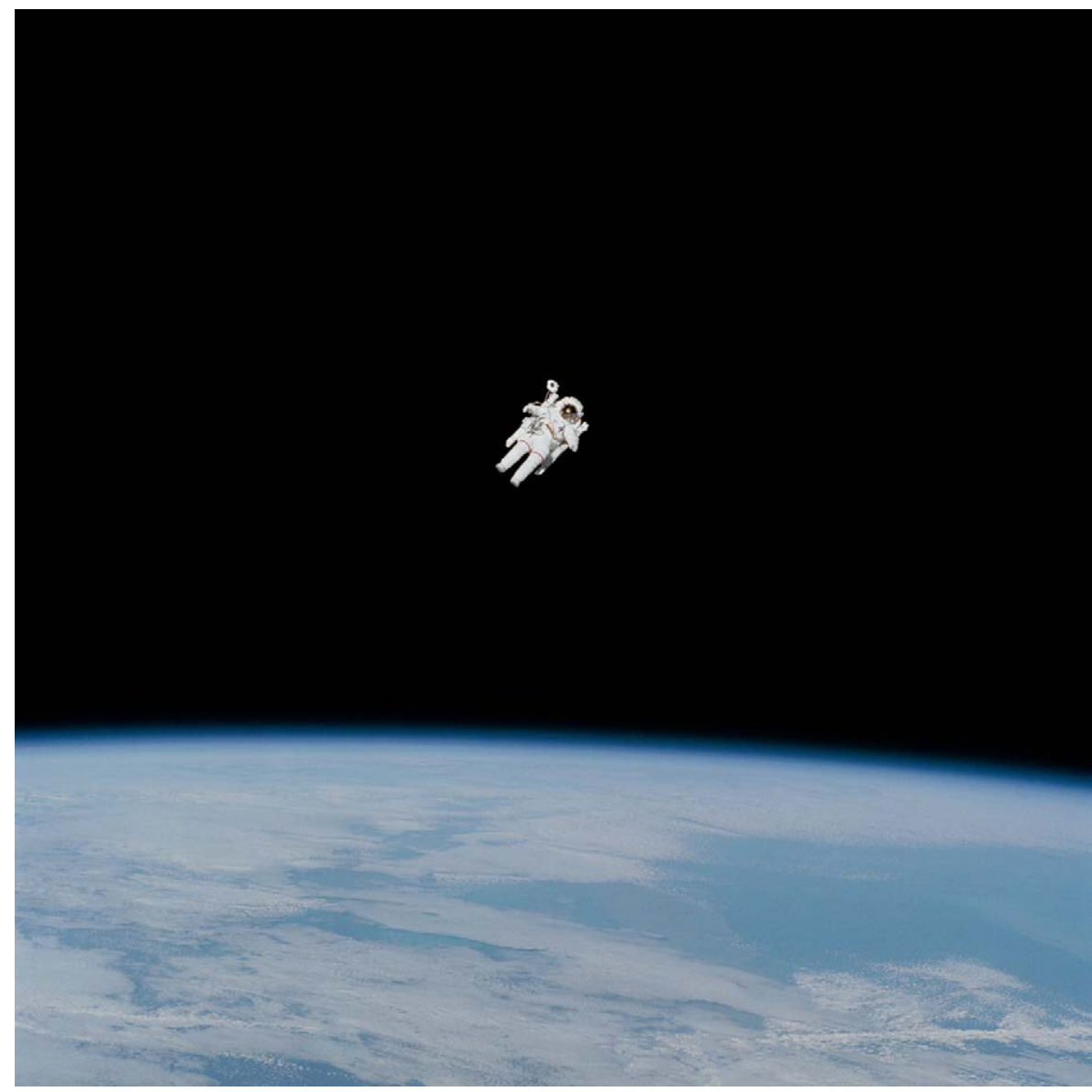

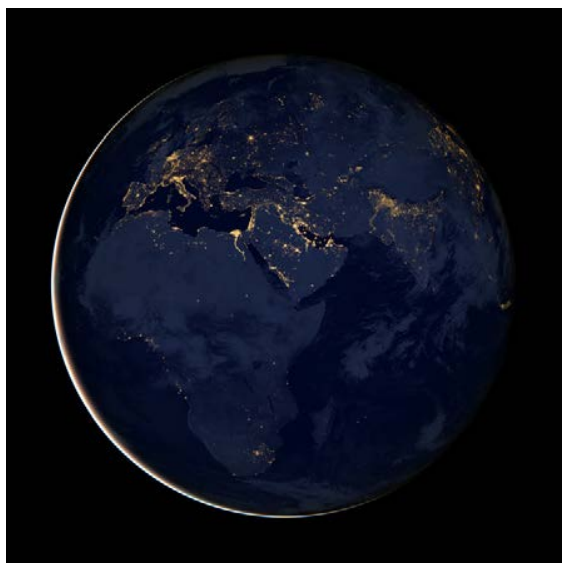

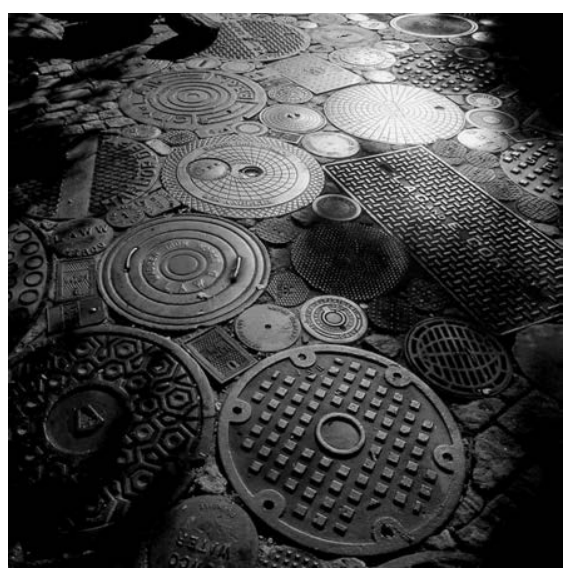

Figura 3. Black Marble (Canica Negra) (2012). [Fuente: CNASA]

Figura 4 Metal Manía Series (SF). [Fotografía: Clldiko Laszlo]

Figura 5.

El astronauta Bruce

$\mathrm{McC}$ andless flotando $\sin$ ataduras en el espacio (7 de febrero de 1984). [Fuente: CNASA]
[2] Sagan, Carl. Pale blue dot. A vision of the human future in space. New York: Random House publishing, 1994.

[3] Brand, Steward. Whole Earth Catalog. California: 1968. 


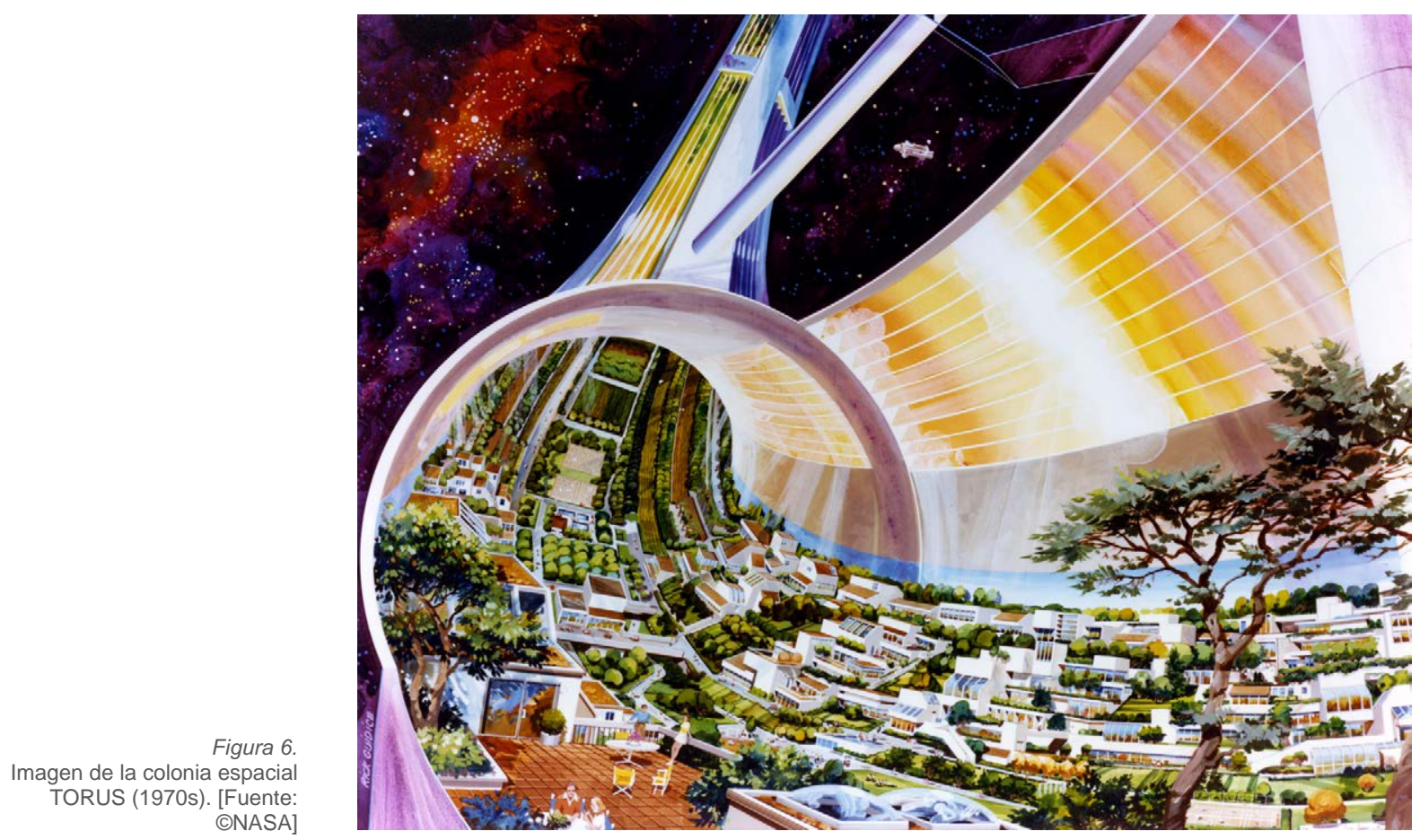

[4] Buckminster Fuller estaba preocupado por la sostenibilidad y por la supervivencia humana en el sistema socioeconómico actual, aunque era optimista acerca del futuro de la humanidad. Definía la riqueza en términos de conocimiento como la «capacidad tecnológica de proteger, criar, apoyar y acomodar todas las necesidades de la vida», su análisis de la condición de lo que él denominaba «Nave Espacial Tierra».

[5] En la patente original, la proyección se mostraba sobre un cuboctaedro. En la siguiente versión, publicada en 1954 con el nombre 'The AirOcean World Map' se servía de un icosaedro, eso sí, algo modificado.

[6] Koolhaas, Rem (ed.) y Easterling, Keller. «Floor». En: Elements of architecture. The Venice Biennale. 14th International Architecture Exhibition. Venezia: Marsilio Editori, 2014. pp. 68-69.

[7] Koolhaas, Rem (ed.) y Easterling, Keller. "Floor». En: Elements of architecture. The Venice Biennale. 14th International Architecture Exhibition. Venezia: Marsilio Editori, 2014. p. 70.

[8] Achenbach, Joel. «The sikes. The limits. The International Space Staion is one of humanity's great engineering triumphs. But what is it for?». The Washington Post. Washington, 14/09/2013. [https://www.washingtonpost.com/sf/national/20 13/09/14/the-skies-the-limits/]. rra» [4] que bautizó el visionario Richard Buckminster Fuller. Sobre ese orbe, que es nuestro suelo, se posan nuestros sueños e inquietudes. También nuestras dudas. Y sobre esa enorme canica móvil que flota en el espacio, construiremos nuestro hogar. Quizá pronto haya que colonizar otros planetas, pero mientras tanto, éste es nuestra primera y única casa.

El propio Fuller patentó en 1946 el Dymaxion Map - también conocida como proyección de Fuller- : se trata de una proyección del mapamundi en la superficie de un poliedro que puede desplegarse en formas [5], preferentemente triangulares, hasta formar una superficie bidimensinoal que permite mantener cierta integridad proporcional relativa al mapa del globo. Es decir, tiene menos distorsión del tamaño relativo de las distintas regiones. El Dymaxion Map carecía de una única dirección, ya que Fuller repetía que en el Universo no existía ni el 'arriba' o el 'abajo', ni el 'norte' o el 'sur'. Para él sólo existía 'dentro' y 'fuera', es decir, la posición relativa respecto a los centros gravitacionales de los planetas y de las estrellas. Así, en el Dymaxion Map desaparece la idea de orientación correcta, ya que cuando se despliegan las caras triangulares del icosaedro resulta un resultado que muestra masas contiguas frente a la idea de la tradicional agrupación en grupos de continentes y éstos, a su vez, divididos por océanos. Esta proyección nos demuestra que nuestros pavimentos nunca son horizontales y que sobre ellos siempre recae la curvatura que heredan al intentar pavimentar el planeta Tierra. Todo lo demás, son simplificaciones en la representación.

El suelo es más antiguo que el pavimento, que el techo y que el muro, pero más joven que el cielo. En el suelo recae la seguridad - también la prepotencia- de reconocerse imprescindible. Ineludible. De ser el primer material de construcción. Vinculado a él se sitúan los elementos. De él, crecen los árboles. Y sobre él, tarde o temprano, se posa la gravedad. La arquitectura confía en el suelo, como el águila cree en sus alas al volar.

Señalar al suelo (a la Tierra) como el germen de la arquitectura parece una osadía. Lo es. Tradicionalmente hemos advertido en el techo - cobijo- la génesis 


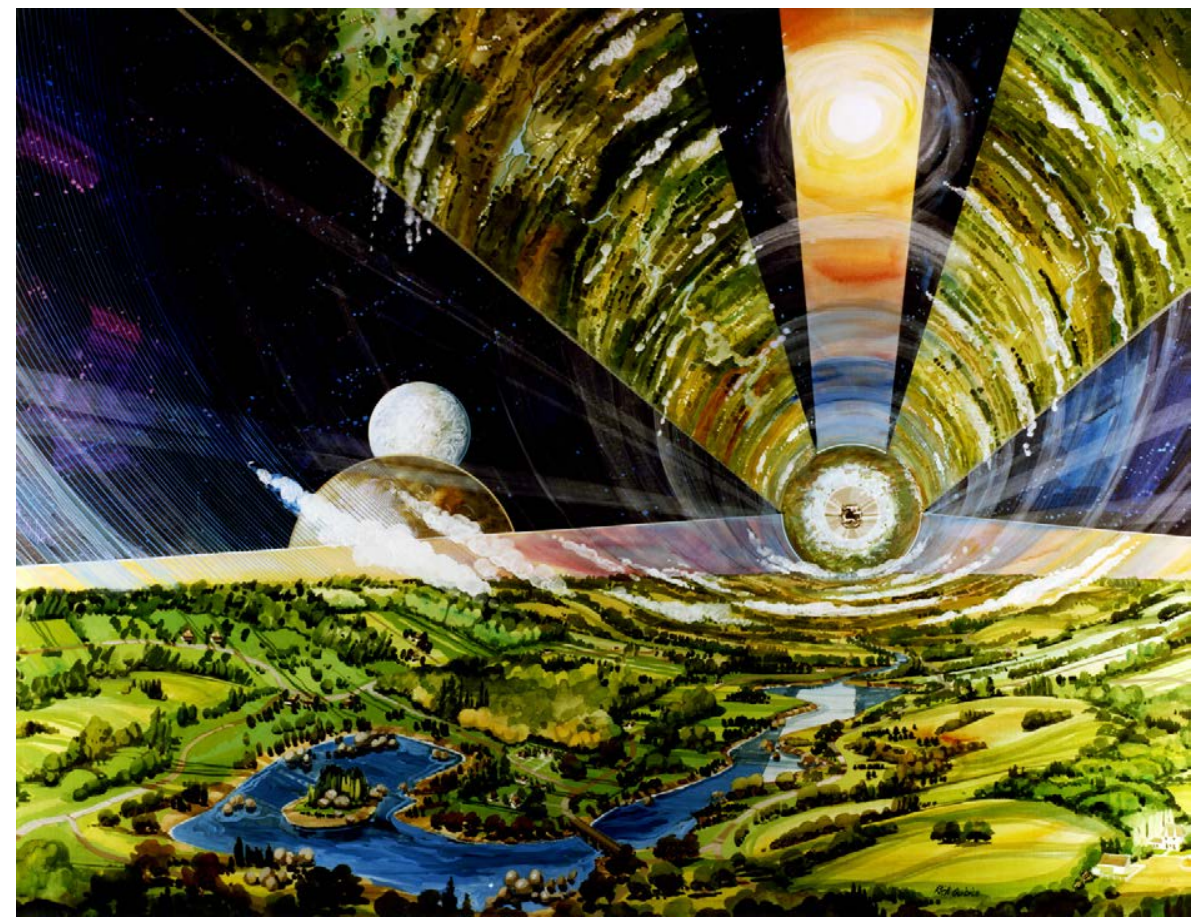

de todo acto arquitectónico. Sin embargo, basta alejarnos de nuestro planeta - y mirarnos desde afuera - para comprender que ese orbe ya es nuestro hogar - haya o no techo- Ese suelo es nuestro primer cobijo en el Universo.

La arquitectura siempre será deudora de ese suelo cósmico que gira sobre sí mismo y cuya órbita está situada en la zona habitable de su estrella (el sol): es decir, la distancia donde la temperatura hace posible la presencia de agua líquida; y unas condiciones atmosféricas compatibles con la vida.

Estos requisitos son previos a cualquier otro. Son premisas ineludibles e indispensables. Y demuestran que, desde afuera, encontramos en el suelo valores que lo señalan como el primer acto arquitectónico.

\section{El suelo sin gravedad}

En la película 2001: Una odisea del espacio (1968) de Stanley Kubrick (19281999), la nave 'Discovery One', que tiene forma de doble rueda o toro, se desplaza girando sobre sí misma hacia el espacio exterior. De ese modo, su fuerza centrífuga simula la gravedad. Los astronautas y viajeros trabajan o duermen en vainas dentro de la forma del toro. Como la superficie del suelo, durante toda la película siempre está cambiando, el director juega con la posición de la cámara, no desde el punto de vista del personaje, sino desde el centro del eje, a veces de la nave, o a veces de un punto fijo en el espacio. Así, se puede ver a alguien corriendo a la misma velocidad de lo que gira la nave, permitiendo que el suelo esté siempre debajo de él. 0 en otra escena, una azafata, después de recoger una bandeja con comida, parece estar caminando - con la ayuda de unos zapatos de agarre de color blancos de la marca Pan-Am- por el techo para acceder a otras partes de la nave [6].

\section{La Estación Espacial Internacional (ISS: International Space Station) lleva} desde 1998 orbitando alrededor de la Tierra y colocada de igual manera respecto a la relación con la superficie del campo gravitacional de la Tierra, por lo que de algún modo, y a diferencia de la película de ficción de Stanley Kubrick, en la
Figura 7.

Imagen de la colonia espacial TORUS (1970s). [Fuente: CNASA] Figura 8.
Imagen de la colonia espacial
TORUS (1970s). [Fuente:

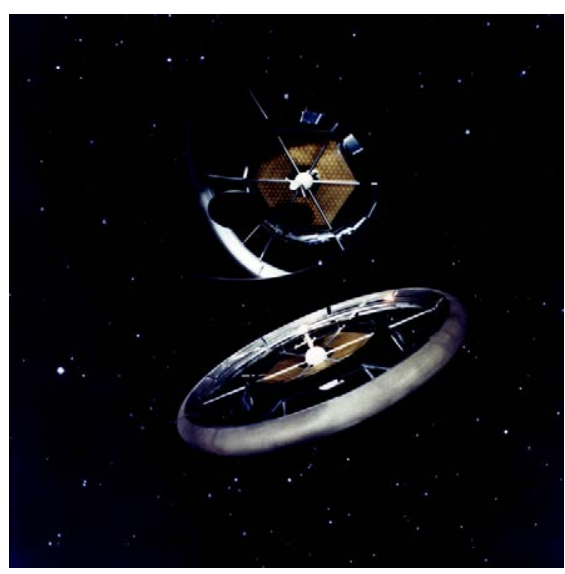



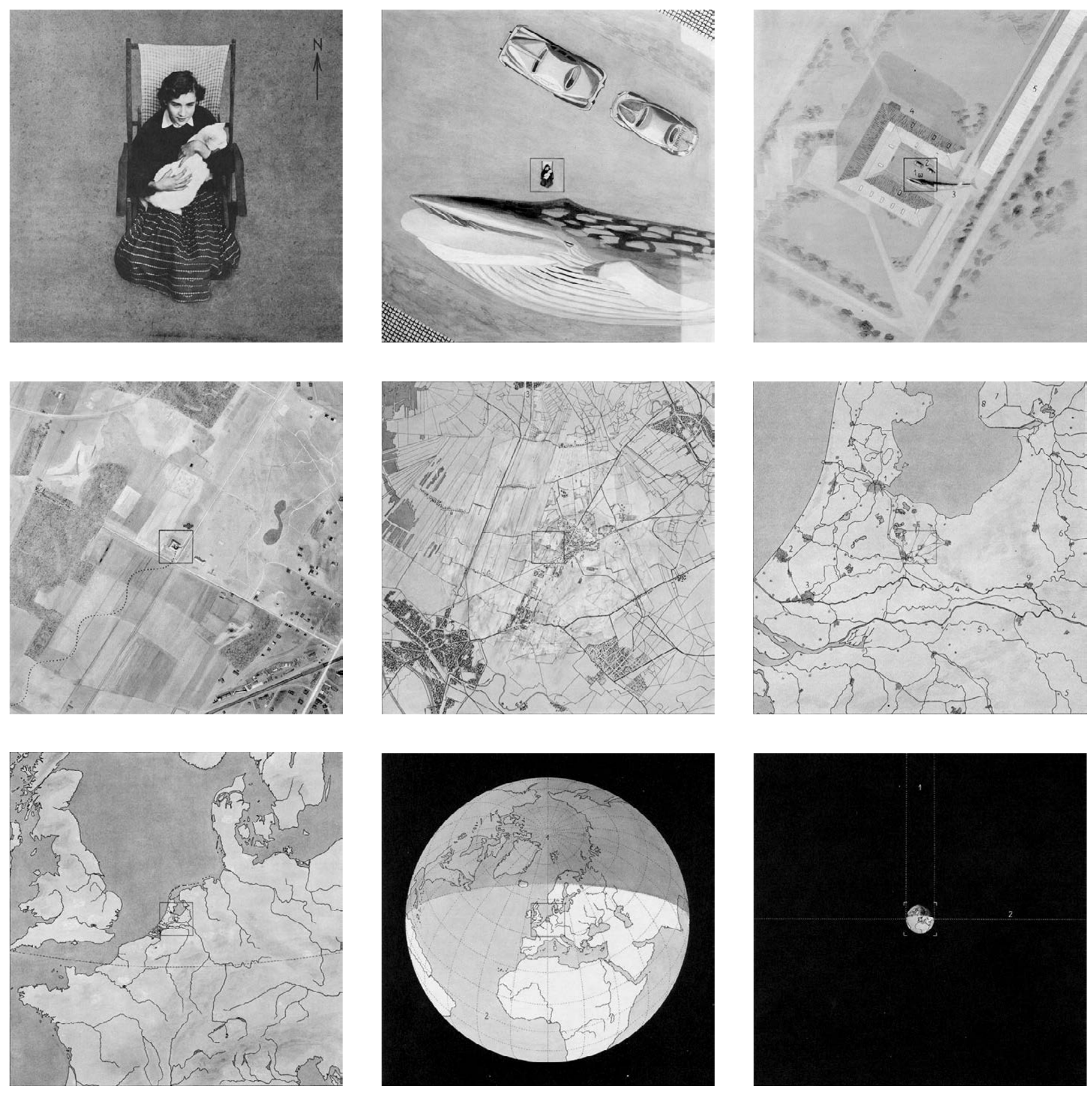

Figura 9. Imágenes del libro Cosmic View: The Universe in Forty jumps (1957). [Fuente: (OThe J ohn Day Company, New York]

[9] García-Sánchez, José Francisco. «Afuera y adentro». Jornadas de introducción a la investigación de la UPCT. Cartagena: AJICT, Asociación de jóvenes investigadores de Cartagena, Universidad Politécnica de Cartagena, abril 2013, núm 6, pp. 22-24.

[10] Boeke, Kees. Cosmic View: The Universe in Forty jumps. New York: The John Day Company,

Estación Espacial Internacional siempre se tiene un dato conocido que es considerado como suelo. Sin embargo, la falta de gravedad, hace que los objetos no se precipiten hacia esa superficie del suelo, como en la Tierra, sino que se muevan y choquen con las paredes o con el techo. Sólo los ordenadores, los botones y los mandos de control - y la leyenda de éstos - disponen de esa orientación en relación al suelo. Por lo tanto, se trata de una superficie de acuerdo ad-hoc [7]. En un artículo publicado en el periódico The Washington Post , Nicole Scott, una de las astronautas que habitó la Estación Espacial Internacional durante un tiempo declaró:

«Los sábados son días de limpieza. Toda superficie es esencialmente un suelo, acumulando suciedad, escamas de piel, gotas de sudor y trozos de comida. (Jan tiene una tendencia diabólica a lanzarse tostadas)» [8]. 


\section{Power of Ten (1977)}

«La mecánica del alma no significa estar adentro. Caminar, respirar, ver, escuchar, los demás, no significa estar afuera. El dentrofuera es un temblor tardío y está ahí: en una lejanía que mece con palabras que vencieron al fuego». (J uan Gelmán, Mundar.)

El arquitecto, como el poeta, debe retranquearse de la vida. No para alejarse de ella, sino para observarla desde fuera y entenderla mejor. Es decir: estar afuera. Pero también debe sumergirse en la vida: Primum vivere deinde philosophare (primero vivir, después filosofar). Ser el protagonista. Participar intensamente de la vida y sus circunstancias. Equivocarse. Es decir: estar adentro. El proceso creativo es un camino de ida y de vuelta. De entrar y de salir. De acercarse y de alejarse [9].

Charles and Ray Eames escribieron y dirigieron para IBM el documental Power of Ten (1977). En él se muestra la escala relativa del universo en factores de potencias elevadas al 10. La película es una adaptación del libro Cosmic View: The Universe in Forty jumps (1957) de Kees Boeke [10] donde se investigaba sobre el tamaño relativo de las cosas. En ambos casos, libro y cortometraje, partiendo de una estampa doméstica - una pareja haciendo un pic-nic tumbada sobre dos mantas, en el caso del cortometraje; y una joven sentada en una butaca con un gato en el regazo, en el caso del libro- y a través de una secuencia de fotogramas, se llega a la inmensidad insondable del Universo. Luego se produce el viaje inverso hasta volver a la escala humana; y desde ahí, a la escala celular microscópica. De lo particular a lo general, a lo Universal. Y luego, el recorrido inverso. Afuera y adentro. Macrocosmos y microcosmos. La parte y el todo. Lo deductivo y lo inductivo.

Aunque no fuera el objeto principal del documental, la primera escena del picnic $\left(10^{\circ} \mathrm{m}\right.$ de lado) de la pareja merendando sobre dos mantas y éstas sobre una pradera de césped cerca de un lago, en Chicago, es elocuente. Unos instantes después, el cuadrado del encuadre de la cámara se aleja hasta que se contempla la imagen completa del planeta, que el documental lo mide en $\left(10^{7} \mathrm{~m}\right.$ de lado). Por tanto, los autores del documental nos muestran los dos principales suelos sobre los que se construye nuestra relación con la tierra: el esencial representado por las mantas sobre el manto de césped cuya eficacia en la fundación de un lugar es incontestable, y el orbe entendido como nuestro suelo en el Universo. Y entre ambas escalas, se proyectan y construyen todos y cada uno de los pavimentos que conocemos. Ése será el ámbito de esta investigación.
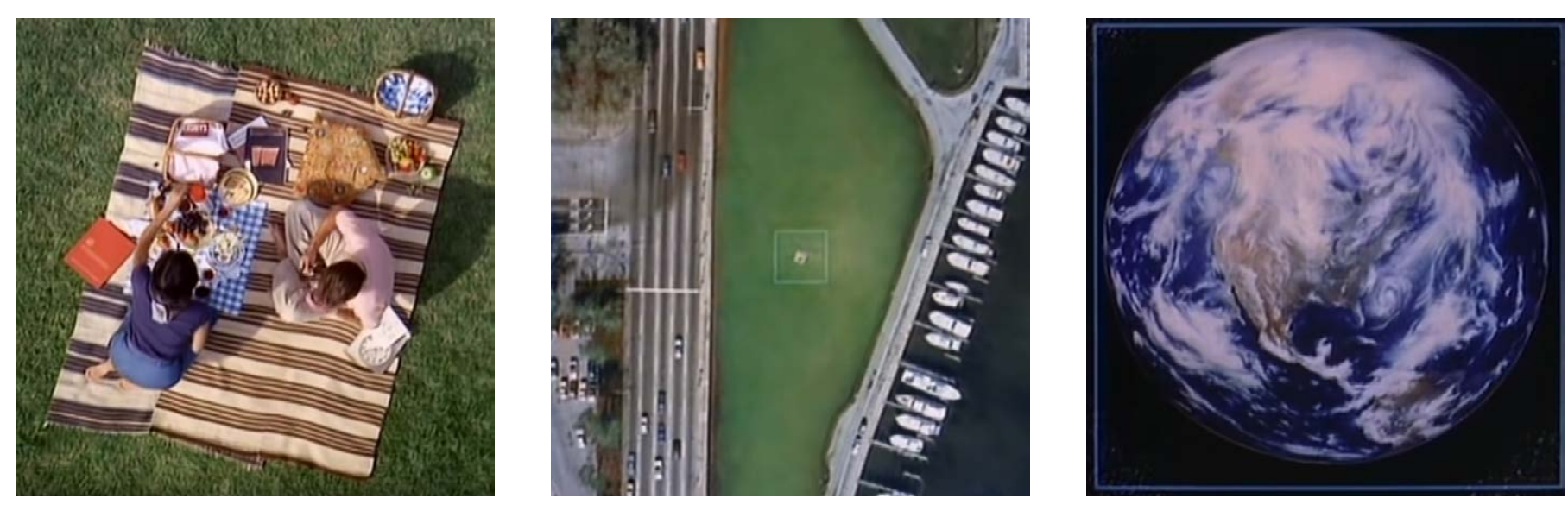

San Marcos lanzado en escorzo, hacen del suelo el protagonista de la obra. Los pies del esclavo tumbado se sitúan sobre la junta de color claro - estando girado el tronco a la izquierda - y la cabeza de San Marcos se sitúa sobre la vertical de la misma junta - estando girado el tronco a la derecha- Es decir: el orden del pavimento, los pies del esclavo y la cabeza del Santo están perfectamente alineados. Pero si abusamos de la metáfora gráfica, y adjudicamos a cada uno de los protagonistas - por su posición- el papel de suelo y de techo, la composición también demuestra cuánto el suelo, tantas veces, es un espejo del techo. Es decir: el orden del pavimento ya se presagia en el techo.

La escena se representa ambientada en un exterior cercado por unas pilastras y una portada renacentista clásica coronada por un frontón, aunque el episodio lo hace bajo un umbráculo formado por una estructura ligera de madera y cubierto por vegetación. A pesar del dramatismo de la escena y de lo que insinúa, Tintoretto elude representar la sangre directamente, pero la sombra producida sobre esa zona, inunda definitivamente de rojo el pavimento. Más allá, en el jardín, el suelo recibe la luz y la claridad que celebra el estar yermo de dolor. Al igual que ocurriera con El Lavatorio (1547), también de Tintoretto, donde el pavimento adquiría el color del líquido que discurría por él - en aquel caso agua- en esta obra, parece insistir el autor en esa idea, pero con la sangre, felizmente, no derramada. 0 al menos, no representada directamente.

\section{Traslación del cuerpo de San Marcos (1562-1566), Tintoretto}

En el lienzo Traslación del cuerpo de San Marcos (1562-1566), como se ha comentado, también de J acopo Robusti Tintoretto (1515-1594) se representa una escena cronológicamente posterior a la que se reproduce en el Encuentro del cuerpo de San Marcos (1562-1566) y que se explicará en el Capítulo 10: «EI pavimento Textil. Alfombras y superposiciones». Aquí, dos mercaderes - Bonus de Malamocco y R usticus de Torcello- roban el cuerpo de San Marcos del calabozo y lo trasladan con la ayuda de un camello aprovechando la tempestad repentina, que provoca la huida de las figuras que habitaban la plaza y que se introducen con celeridad en la arquería de la izquierda, para guarecerse de la lluvia.

La escena se sitúa en una plaza porticada cuyo pavimento está compuesto de grandes losas cuadradas de color siena unidas por estrechas piezas blancas que la flanquean en sus cuatro lados. En la esquina de las losas grandes se sitúa una pieza de formato cuadrado y color oscuro cuyo lado coincide con el menor del rectángulo estrecho claro. El monótono color de las piezas grandes y su exagerado tamaño hacen que adquieran condición de fondo, de paisaje o de base, sobre la que se sitúa la malla de piezas blancas - en cuyos cruces se sitúa la hermana menor de color oscuro- y que adquiere el protagonismo geométrico del suelo de la plaza.

Las líneas blancas, paralelas a la base del lienzo, se encargan de ordenar la galería de la izquierda - tantas líneas, tantas columnas-, mientras que la línea blanca, la vertical, actúa de eje - aunque ligeramente desplazado a la izquierda- que equilibra la escena. Sobre ella se sitúa el punto de fuga. A la derecha, el camello y los dos hombres del primer plano arrastrando el cadáver de San Marcos aportan el peso visual suficiente para sostener la arquitectónica galería iluminada de la izquierda. Es decir, la línea blanca, esa línea, ayuda al pintor a separar el mundo en dos, 0 al menos el cuadro. También actúa de sendero improvisado, de guía sobre la que el quinteto y la camella descienden literalmente por el lienzo. 
Figura 12. Traslación del cuerpo de San marcos (1562-1566). [Fuente: (c) allerie Accademia, Venezia]

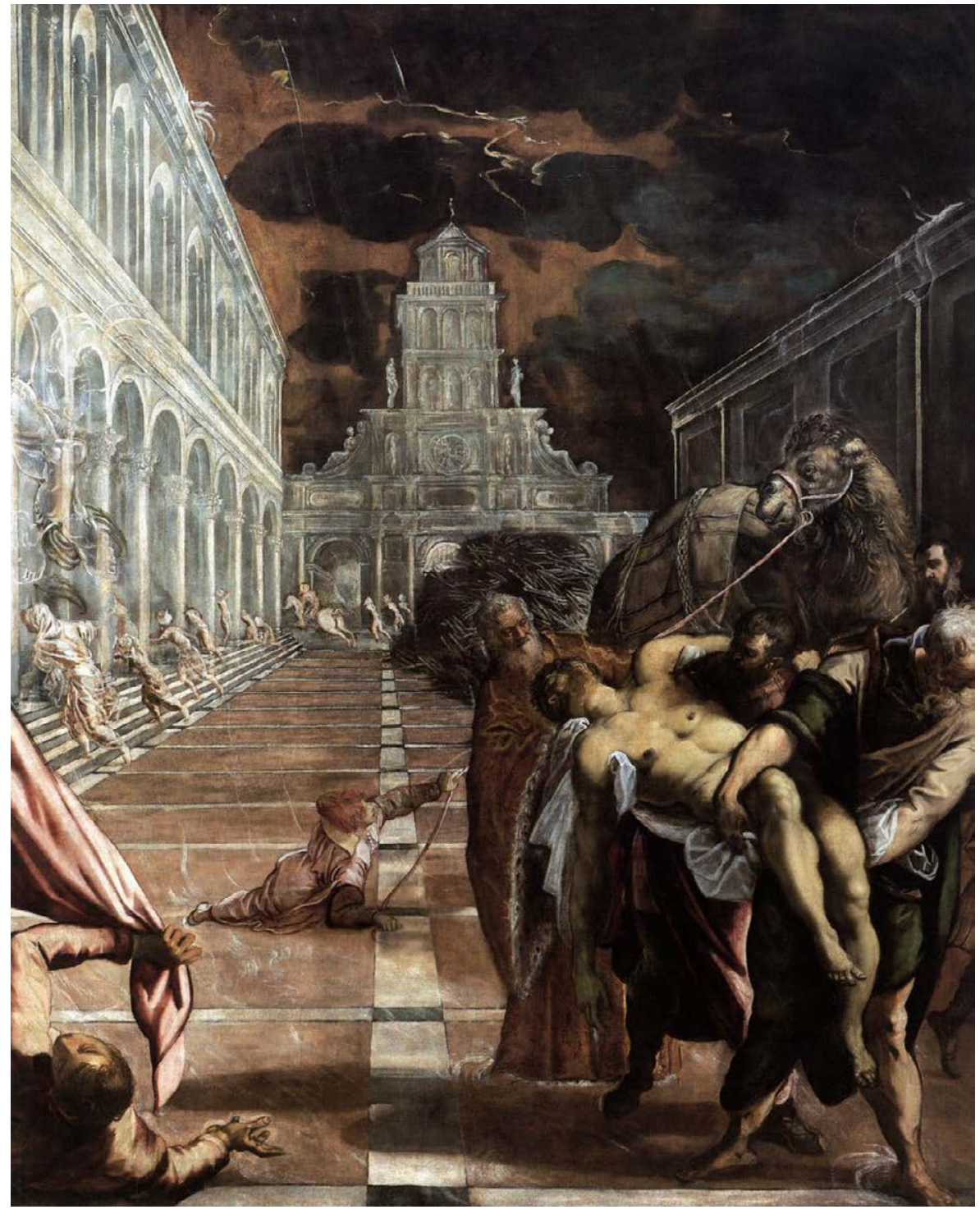

El cielo, negro como un tizón, descarga su ira y su agua sobre la plaza que definitivamente acaba encharcada. Tanto el hombre que intenta domesticar al cameIlo - o aprovecharse de él para no caerse-, como el que se intenta sujetarse a un trapo, acaban derrotados, vencidos y en el suelo. Quizá ese sea el castigo que todo pavimento pulido exterior recibe, cuando la lluvia sobre él pone en contacto el agua con los pies de cualquier hombre.

Tanto las líneas del pavimento como el plano del suelo, aspiran a ser un derramamiento horizontal de una extensión superlativa; también demuestra tener la fuerza para fundar la idea de ciudad, para dar lugar al espacio público, a ese lugar que se encuentra ante el edificio, junto al edificio y que supone una definición en germen del sentido de la ciudad: ese lugar, ese intersticio creado por la suma de los edificios. También ocurre en la pintura de la Ciudad Ideal, atribuido a Piero della Francesca (1475) o en la Plaza de P io II en Pienza de Bernardo Rossellino, y su idea de establecer un cierto orden autónomo que se pudiera expandir hacia los edificios.

En ambos cuadros, pero de forma más evidente en este último, el pavimento está compuesto por grandes losas cuadradas, separadas entre sí por unas piezas de color claro, exagerando la junta. Existe por tanto una voluntad de subra-
[9] García-Sánchez, José Francisco. «Afuera y adentro». Jornadas de introducción a la investigación de la UPCT. Cartagena: AJICT, Asociación de jóvenes investigadores de Cartagena, Universidad Politécnica de Cartagena, abril 2013, núm 6, pp. 22-24.

[10] Boeke, Kees. Cosmic View: The Universe in Forty jumps. New York: The John Day Company, 1957. 
yar su exterioridad: el tamaño de los elementos de la arquitectura siempre es preso del tamaño de la obra, y los pavimentos exteriores buscan en su dimensión satisfacer los requerimientos funcionales y simbólicos que recaen sobre ellos.

Esto ocurre, por ejemplo, en la Unité d'habitation (1947-1952) de Marsella de Charles-É douard J eanneret-Gris, Le Corbusier (1887-1965): donde la escala del pavimento doméstico de madera de los dormitorios, contrasta con las piezas de las terrazas exteriores: unas losetas cerámicas de tamaño medio de color tierra y de formato cuadrado; y finalmente con las grandes losas de hormigón gris situadas en el espacio público de la cubierta, cuya escala dialoga con el paisaje que desde allí se contempla, y que con tanto acierto retrata el fotógrafo René Burri (1933-2014). O los pavimentos irregulares de pizarra que desde el exterior se adentra en el interior de la planta baja, diluyendo cualquier límite entre el interior y el exterior, también parecen querer mimetizarse con ese entorno natural del que la propia pizarra procede.

EI pavimento del Pantheon (118-125) de Roma, ordenado a construir por Publio Elio Adriano (76-138) en el lugar del templo erigido por Marco Agripa (63-12 a.C.) es, en gran parte original. Si bien se ha restaurado a lo largo de la historia, al última de ella durante el pontificado del papa Pio IX en 1872. El pavimento se construye con mármol pavonazzetto (o frigio) - un mármol de color blanco cuajado de vetas o gayas de color púrpura o marrones-, con cuadrados alternos de giallo antico y círculos de pórfido y granito. «Los ochos altares menores son antiguos, al igual que el suelo compuesto de giallo, granito y pórfido» [11].

El pronaos octásilo - con cuatro columnas de profundidad, la última en forma de pilastra- presenta un pavimento de grandes piezas de mármol, dispuestas

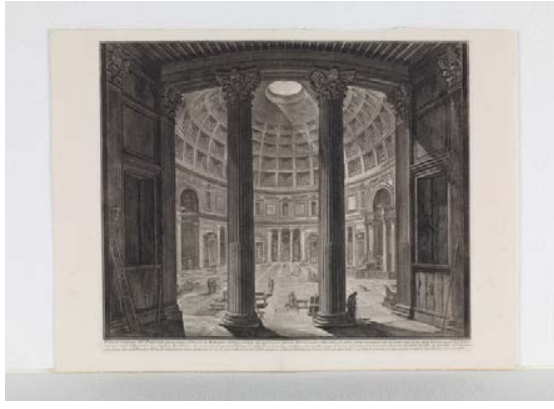

Figura 13 Vista interior del Panteón [Vedute di Roma] (1769) Giovanni Battista Piranesi. [Fuente: CMuseo Nacional de Prado, Madrid. G002999]

1. Whate THE GROUND-PLAN OF THE PANTHEON AT ROME.

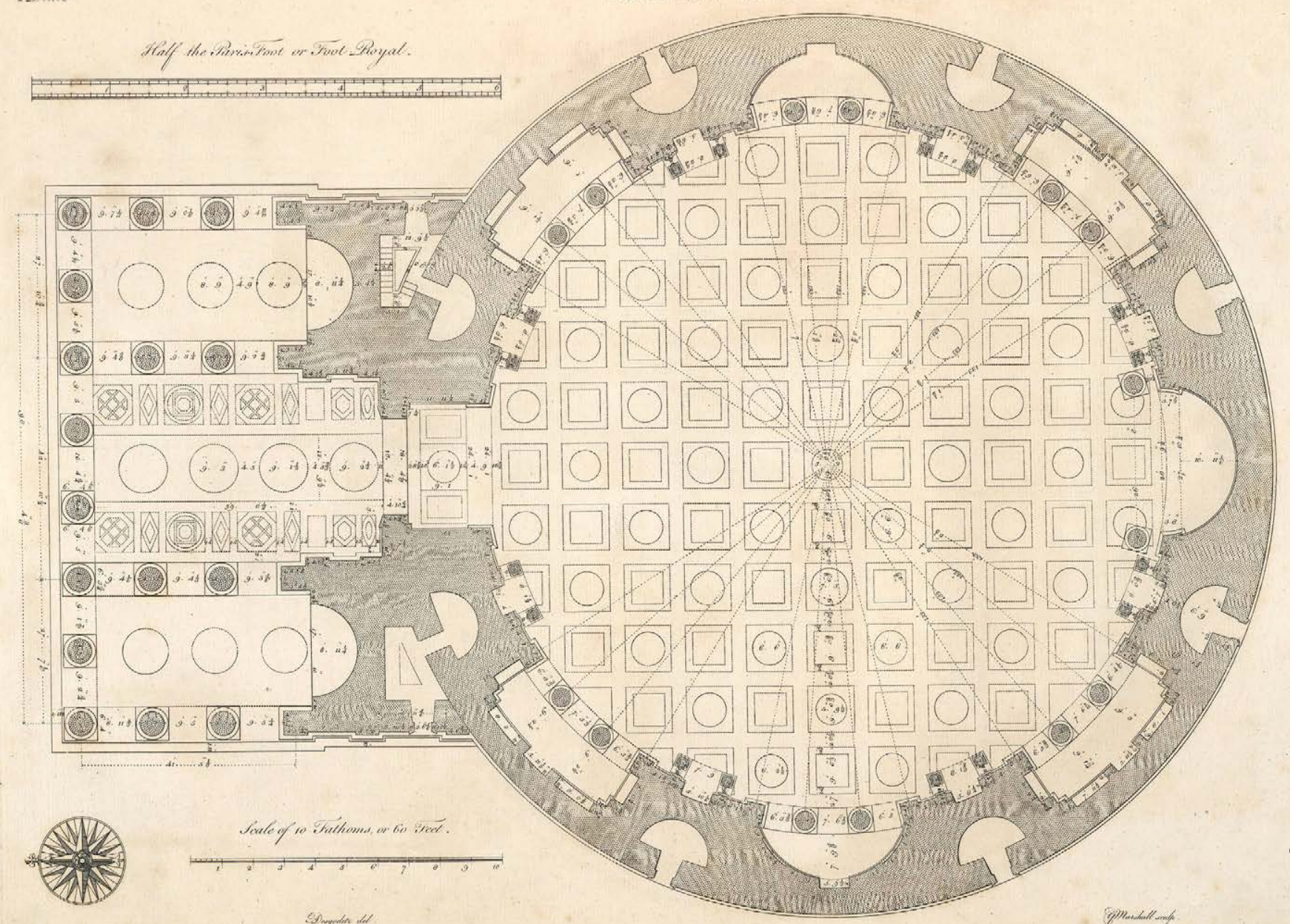



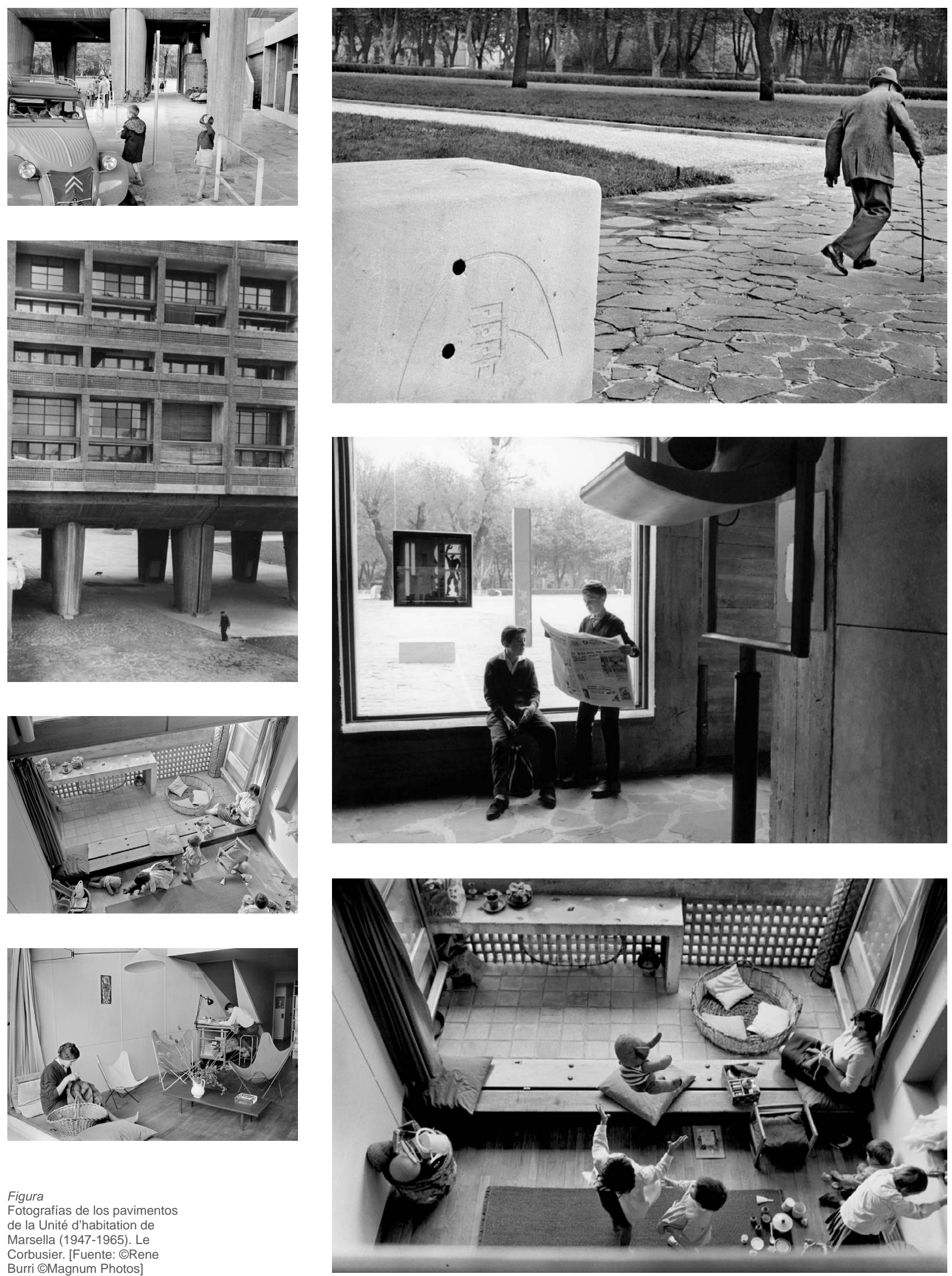

Fotografías de los pavimentos

de la Unité d'habitation de

Marsella (1947-1965). Le

Corbusier. [Fuente: ORene

Burri OMagnum Photos] 

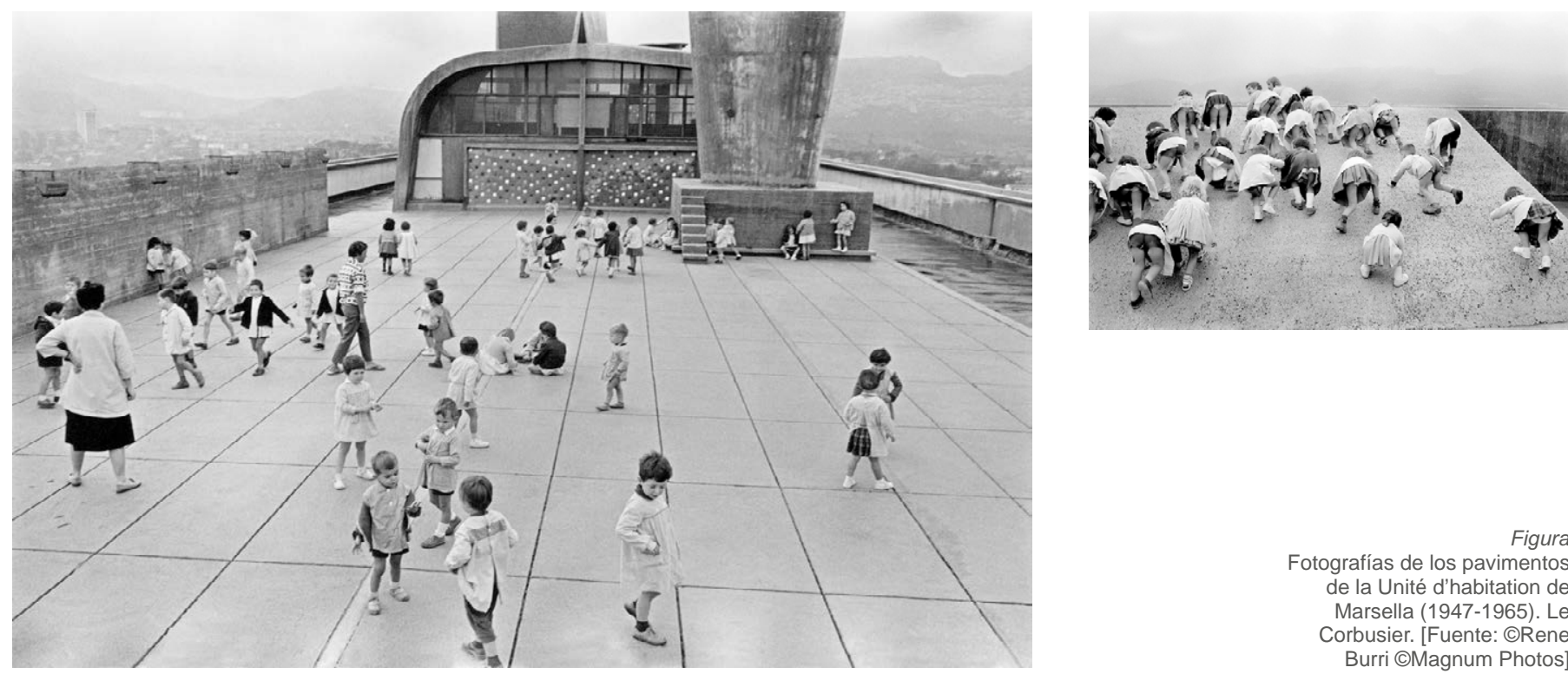

Figura de la Unité d'habitation de Marsella (1947-1965). Le

Corbusier. [Fuente: ORene Burri @Magnum Photos] 
y para tal propósito sólo bajo el Imperio. El pavimento no es horizontal, sino que se inclina desde el centro hacia la circunferencia, como el suelo inferior de la arena del Colisseo. El pavimento, por lo tanto, pertenece a un espacio circular abierto a la lluvia; $y$ se ha descubierto una pared circular, construida de mampostería reticulada alrededor de la estructura actual, a la que es concéntrica. Se ha encontrado el mismo pavimento corriendo debajo del pórtico, a una profundidad de 5 pies. El lecho de hormigón tiene un pie de espesor; las losas de mármol de dos a tres pulgadas» [12].

\section{El pavimento y la forma}

A lo largo de la historia, se ha podido comprobar cuánto la forma del pavimento establece una relación de simpatía con las formas de la arquitectura a la que pertenece. Se produce, por tanto, una reverberación entre la forma del pavimento y la forma de la casa. Algo parecido le sucede a los pavimentos circulares - tanto del jardín de la planta baja como los de la cubierta junto a la piscina- de Torres Blancas (1964-1968) de Francisco J avier Sáenz de Oíza (19182000) o del Conjunto Galaxia (1966-1974) de Antonio Lamela (1926-2017), ambos en Madrid. También el terrazzo de forma circular que coloniza el vestíbulo y asciende por la rampa del Museo Guggenheim (1959) de New York de

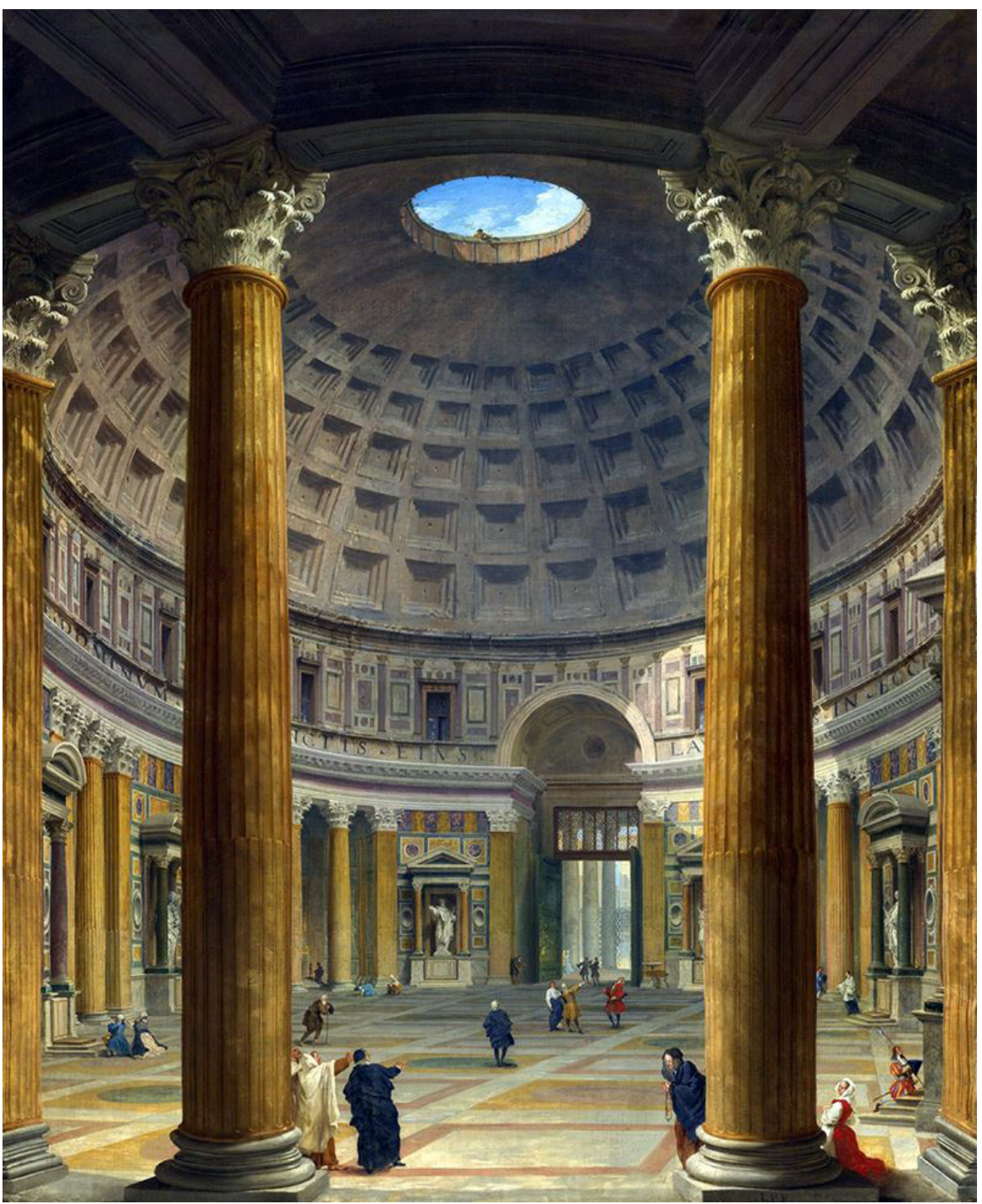

Figura 16.

The interior of the Pantheon in Rome (1735). Giovanni Paolo Pannini. [Fuente:

CLiechtenstein. The Princely Collections]
Figura 17 Planta de pavimentos de mármol del Pantheon de Roma (SF). [Fuente: OSF]

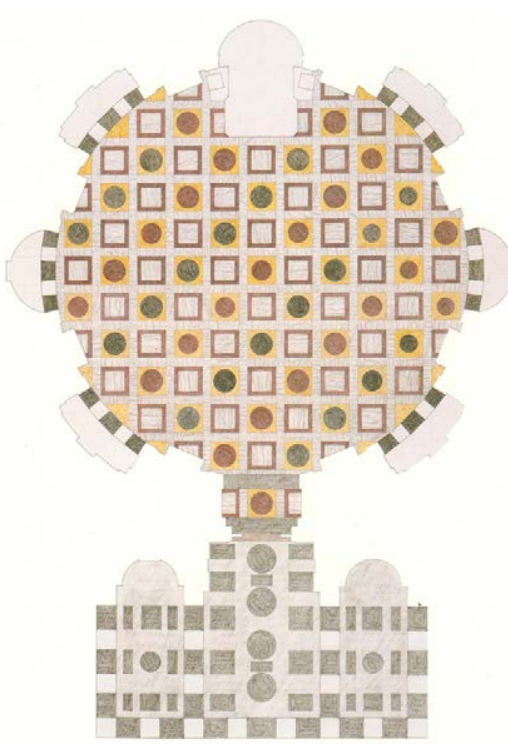



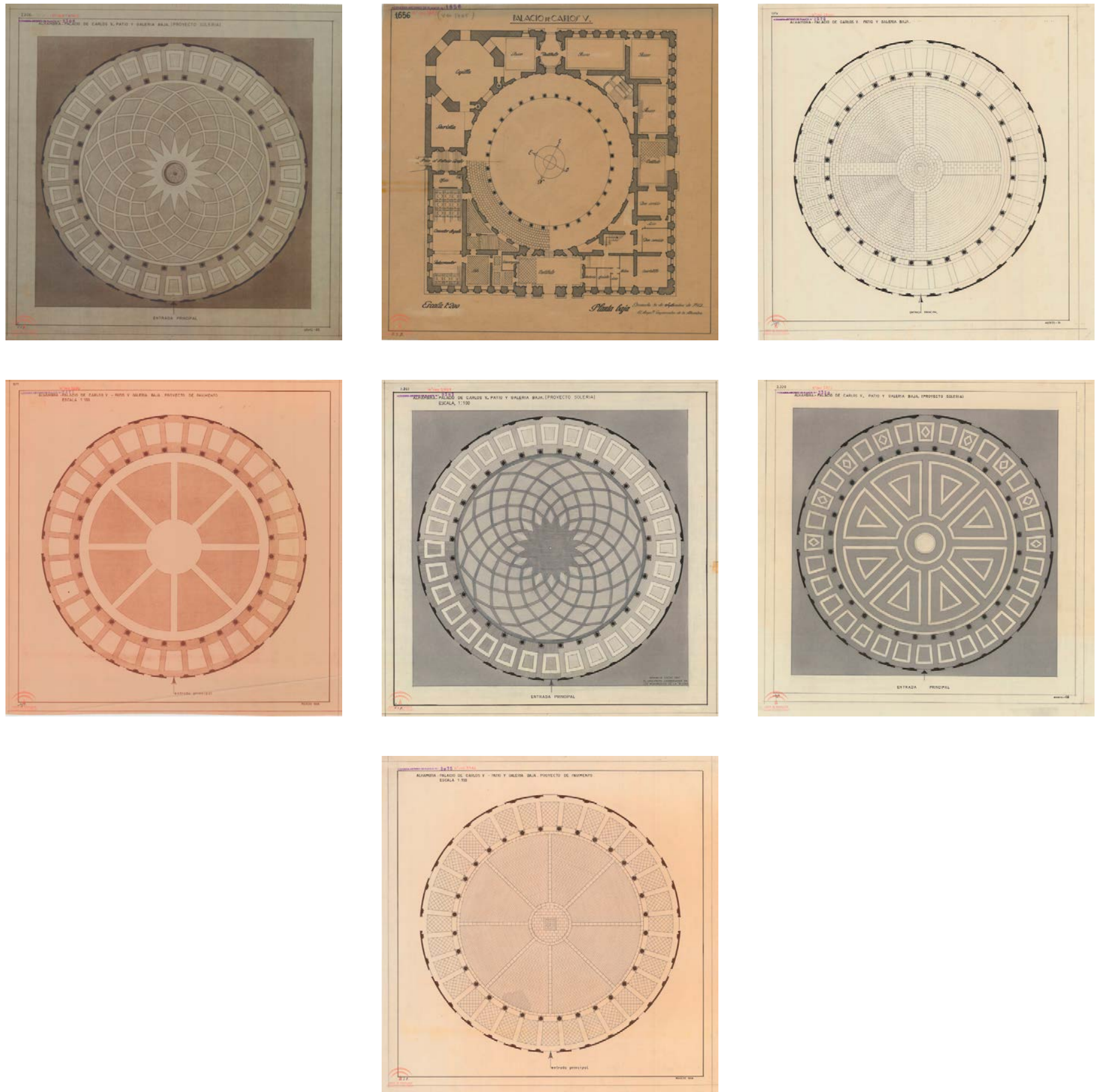

planta de pavimentos del

Palacio de Carlos V de

Alhambra de Granada (VF).

[Fuente: CArchivo Alhambra de

GranadaSF ] 
Frank Lloyd Wright (1867-1959) parece querer insistir en los ecos circulares que forman la planta del museo, que llegan incluso hasta la forma de algunas ventanas. Los pavimentos adoquinados del paseo de Copacabana (1970) en Rio de J aneiro de Robert Burle Marx (1909-1994) también parecen recibir en su geometría de ondas parabólicas, la forma de las olas del mar, según cuenta Bruno Zevi. La fuerza del viento traslada las olas del mar a las ondas dibujadas sobre el suelo, haciendo que se difumine la línea que separa la playa con el suelo pavimentado de la ciudad. Es como si el pavimento, en algunas obras de arquitectura, presintiera la forma del edificio.

\section{Museo Guggenheim (1959) de New York}

Después del hormigón, el terrazo (terrazzo) es el segundo material más usado en el Museo Guggenheim (1959) de New York de Frank Lloyd Wright (18671959). Una obra que para P hilip J ohnson (1906-2005) era: «Mr. Wright's greatest building. New York's greatest building». En una carta enviada a George N. Cohen (1920-) de la Euclid Contracting Corporation, en enero de 1957, Frank Lloyd Wright confiesa que fue en el aeropuerto de Roma donde tuvo una especie de epifanía laica:

«Cuando caminé por el suelo del aeropuerto de Roma, dije: -aquí está, el pavimento ideal para nuestra rampa. No es excesivamente caro o ellos no lo hubieran usado en 'acres' [centenares de metros cuadrados] para el suelo del aeropuerto italiano. El nombre del compuesto es Acmetyle Terrazzo (30 Church Street, New York 7)... No aceptaré nada no familiarizado con este producto» [13].

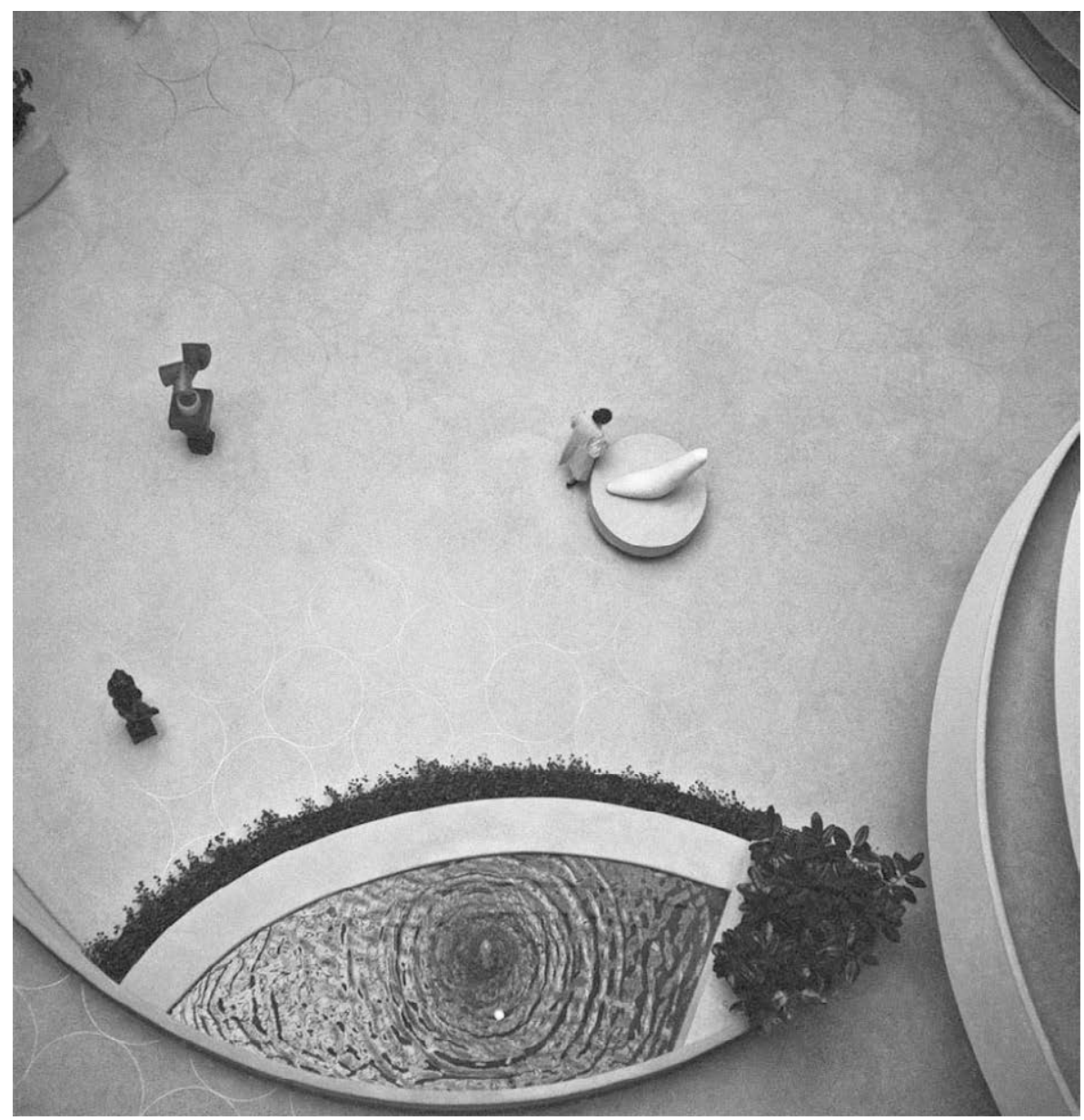

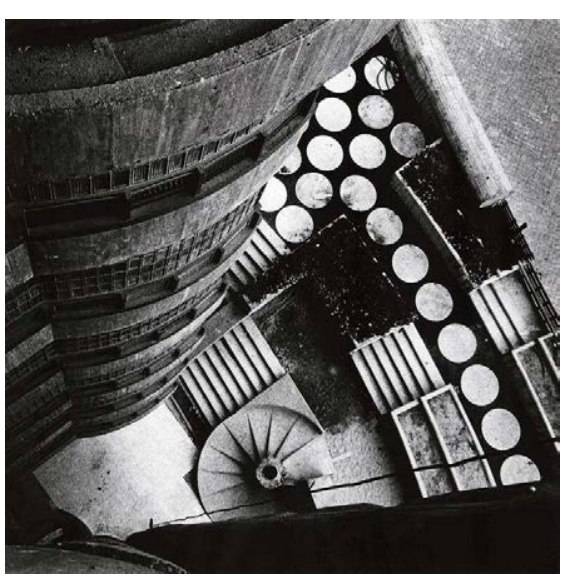

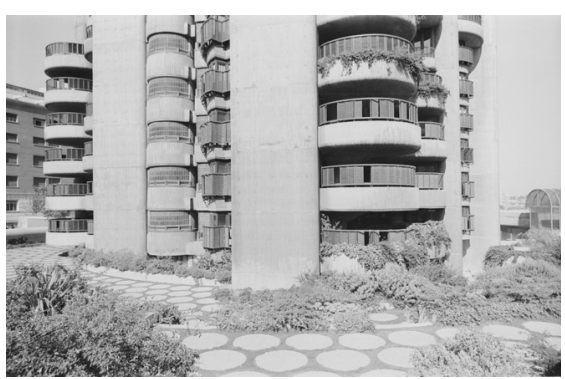

Figura 19

Pavimentos circulares en Torres Blancas, Madrid (1964 1968). Francisco J avier Sáenz de Oíza. [Fuente: CArchivo Sáenz de Oíza]

Figura 20.

Pavimentos de terrazzo circulares en el Museo Guggenheim de New York (1959). Frank Lloyd Wright. [Fuente: CMuseo Guggenheim de New York]

[13] Chusid, Megan. Frank Lloyd Wright's Inspiration for the Guggenheim's Terrazzo Floor. New York: The Salomon R. Guggenheim Foundation, 14 de noviembre de 2014. [https://www.guggenheim.org/blogs/checklist/fra nk-lloyd-wrights-inspiration-for-the-guggenheimsterrazzo-floor[ (01/01/2018).

[14] Según Emma Allen, actual editora de las caricaturas del semanario The New Yorker: «El talento de Alan Dunn como dibujante de arquitectura imbuye a la escena un sentimiento informado, algo creíblemente real. No estoy segura si el diálogo fue escuchado, imaginado o una combinación de ambas, pero ciertamente Dunn ha realizado un estudio del ambiente del Museo»

Chusid, Megan. Frank Lloyd Wright's Inspiration for the Guggenheim's Terrazzo Floor. New York: The Salomon R. Guggenheim Foundation, 14 de noviembre de 2014

[https://www.guggenheim.org/blogs/checklist/fra nk-lloyd-wrights-inspiration-for-the-guggenheimsterrazzo-floor[ (01/01/2018). 


\section{THE GUGGENHEIM}

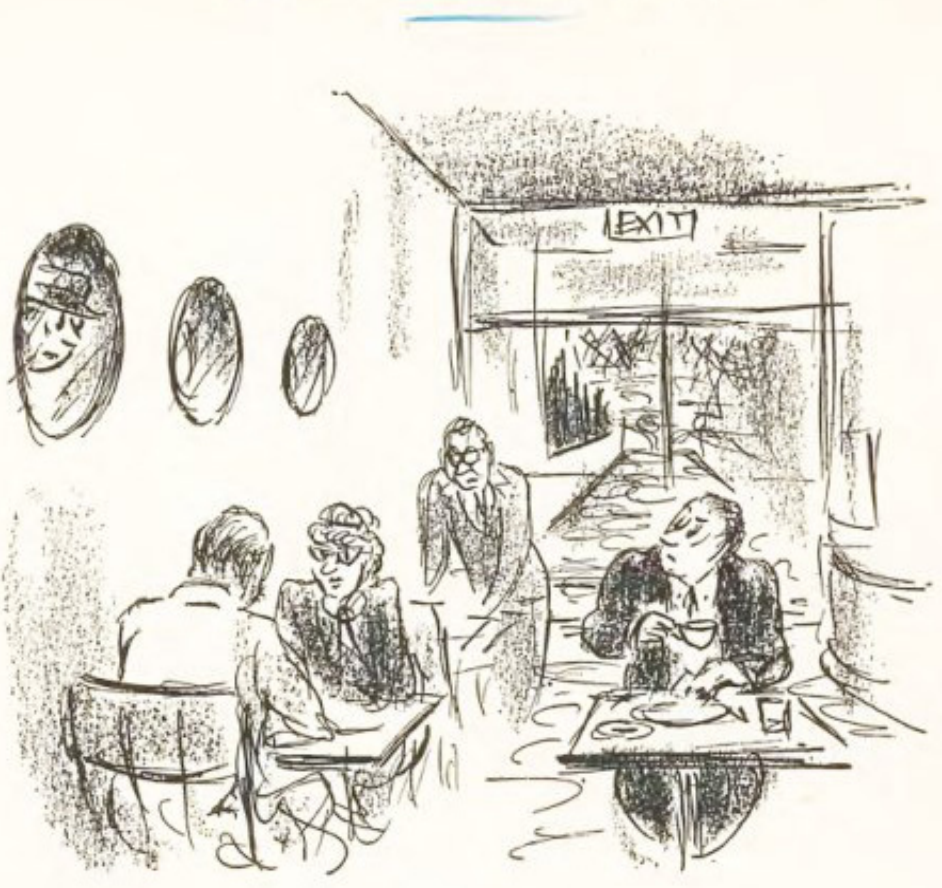

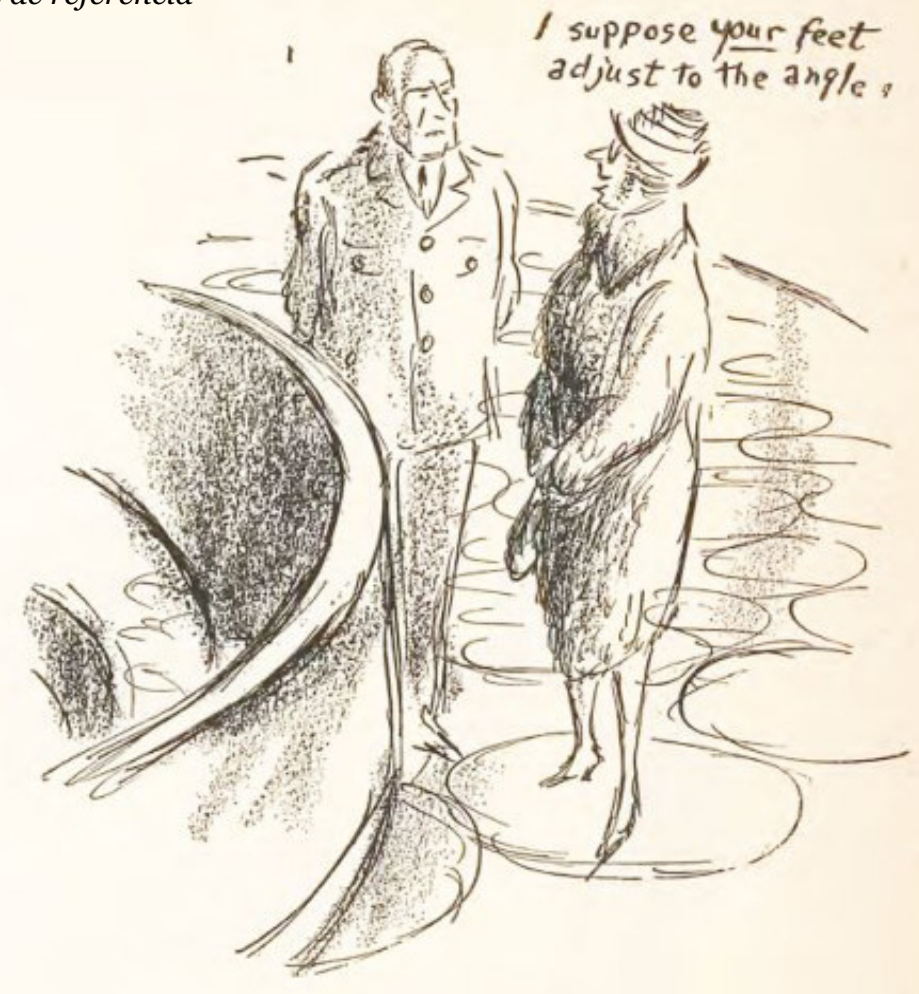
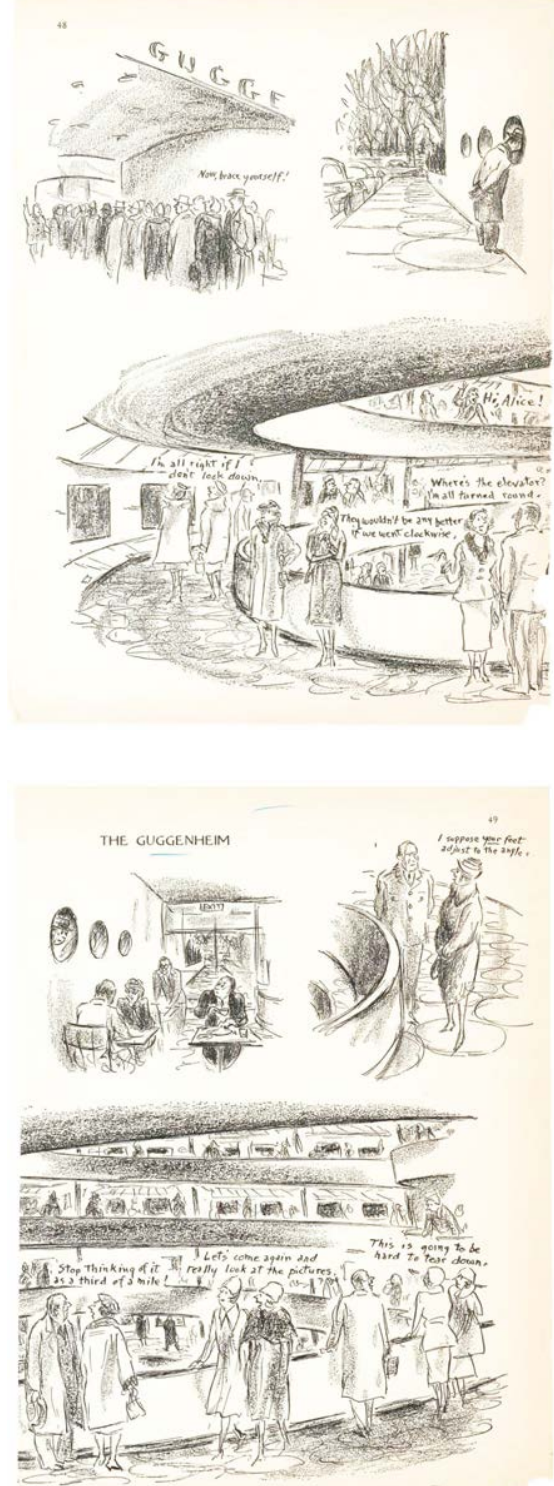

En esta obra, los círculos del pavimento de terrazzo son un eco formal reverberante de la forma del edificio. Es como si el pavimento presintiera la forma de la obra a la que pertenece. En el Museo Guggenheim de New York estos círculos aparecen ya desde el exterior - aquí todavía construidos de hormigón in situ-.

Esto se aprecia bien en los dibujos que Alan Dunn realizó para la revista The New Yorker el 28 de noviembre de 1959. En ellos aparecen reflejados los círculos de terrazzo tanto los exteriores como los de la rampa. En los dibujos aparecen reflejados personajes y algunos de ellos realizan comentarios [14]. Los visitantes de Dunn investigan con curiosidad las ventanas circulares, introduciendo la cabeza. Además, en ellos se percibe el pavimento circular exterior. En otro dibujo se representa esa misma escena pero desde el interior donde el mismo personaje comprueba, esta vez, el paisaje interior pavimentado, insistiendo en la redundancia del círculo aquí y allá. En otra escena se puede ver a una pareja en una de las rampas, con los pies sobre los círculos de terrazzo, y que se produce el siguiente diálogo, cuando ella le pregunta a él:

«I suppose your feet adjust to the angle / Supongo que tus pies se ajustan al ángulo». Además de otras conversaciones: «Stop thinking of it as a third of a mile! / Let's come again and really look at the pictures / This is going to be hard to tear down / I'm all right if I don't look down / They wouldn't be any better if we went clockwise / Where's the elevator? I'm all turned round / Reminds me of the old Wanamaker's».

En marzo de 1952 propone que: «... and floors will be thin cork slabs stained pale grey; or floors may be grey rubber tile» [15] y el 16 de mayo de 1958 escribe: «Occasional sculpture may rise from oval or circular masonry pedestals of the same color and material as the floor and walls of the Museum» [16].

«... All is one great space on a continuous floor... the net result of such construction is greater repose, an atmosphere of the unbroken wave...» [17].

El terrazzo de la rotonda del Guggenheim todavía permanece, sin apenas desgaste, como el testigo silente de ese icónico contenedor artístico [18]. Y todo ello, pese a ser pisado por millones de visitantes cada año. En los 430 m (1416 pies) longitudinales de rampa, es posible encontrar tres tipos de terrazos de 
color crema natural, que no son otra cosa que las tres renovaciones que ha tenido el Museo. Así, entre 1968-1972 se llevó a cabo una renovación en la galería Thannhauser, al comienzo de la rampa número 2. En 1992 se produjo otra actualización del pavimento en la galería principal, pero sigue siendo un paisaje de círculos infinitos.

\section{Las formas sensuales de Roberto Burle Marx}

El trabajo de Roberto Burle Marx (1909-1994) no recibió el reconocimiento internacional hasta que el MoMA organizó la exposición Roberto Burle Marx: the unnatural art of the garden en 1991 [19] y editó un libro-catálogo con el mismo título [20]. En la retrospectiva se examinaba la larga carrera de 60 años del arquitecto y paisajista brasileño. Fue la primera exposición que el museo dedicaba a esta disciplina y, de algún modo, casi en el ocaso de su vida, tuvo todavía la oportunidad de que el mundo conociera su trabajo. Desde la década de 1930, Burle Marx diseñó, proyectó y construyó alrededor de 3.000 jardines, la mayoría de ellos en América del Sur. El abanico de sus intervenciones se desplegaba desde el trazado de pequeños jardines domésticos, el paisajismo vinculado a los lugares del trabajo o el diseño de los pavimentos y jardinería de los grandes escenarios urbanos y parques públicos modernos, a veces, como colaborador de Le Corbusier, Oscar Niemeyer o R ino Levi.

Burle Marx incorpora en su investigación sobre el paisaje, una mirada creativa fruto de su formación artística y de un profundo conocimiento de la jardinería y de la horticultura. Esta simbiosis entre el paisaje agrícola, la construcción de paisajes pavimentados y el interés por el arte, le llevan a depurar un lenguaje de líneas precisas y formas entrelazadas que revelan una afinidad por el arte abstracto, especialmente por el trabajo de Alexander Calder, J ean Arp, Fernand Leger o J oan Miró, entre otros. Pero su lenguaje geométrico se puede también vincular al repertorio formal de las obras de Pablo Palazuelo: trazos donde la aparente aleatoriedad encuentran en unas reglas internas el modo en el que las líneas rectas se enlazan con otras, mediante un arco que elimina el encuentro en ángulo.

Y, desde luego, al modo en el que Paul Klee, y otros contemporáneos, se entretenían en investigar cómo rellenar el espacio con trazos y líneas.

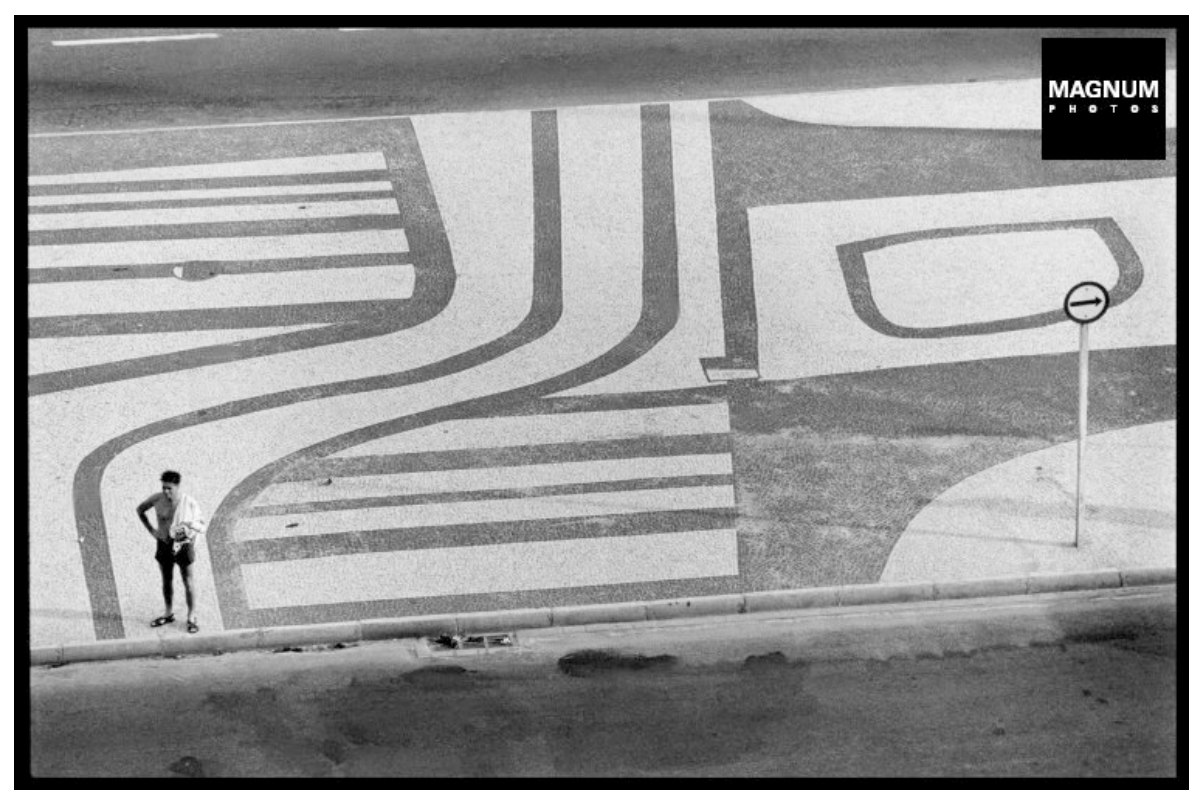

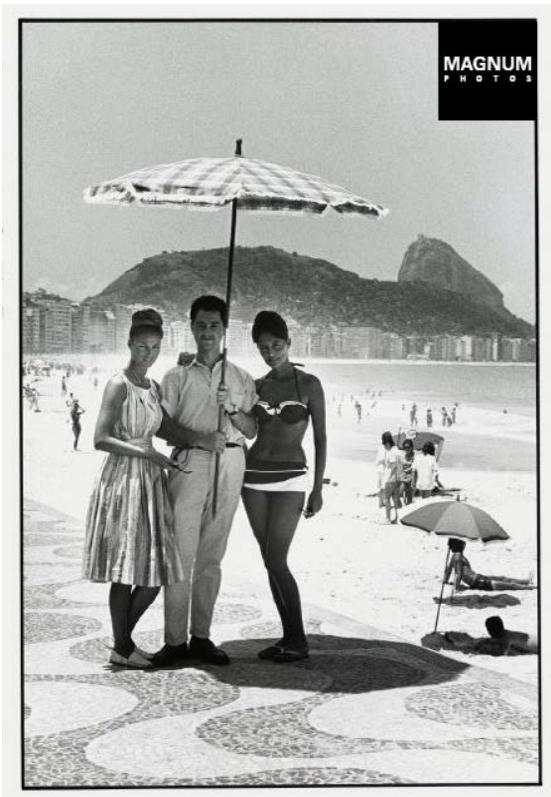

Figura 22 Pavimentos en el Paseo de Copa Cabana, en Río de $J$ aneiro, Brasil (1970). Roberto Burle Marx. [Fuente: (CElliot Erwitt (Magnum Photos]

Figura 21. Página anterior. Caricaturas aparecidas en la revista The New Yorker donde se aprecia el pavimento circular del Museo Guggenheim de New York (28 de noviembre de 1959). Alan Dunn. [Fuente: (CThe New Yoker]
Figura 23.

Pavimentos en el Paseo de

Copa Cabana, en Río de

J aneiro, Brasil (1970). Roberto

Burle Marx. [Fuente: @E lliot

Erwitt @Magnum Photos]

[15] Lloyd-Wright, Frank. The Salomon $R$. Guggenheim Museum. New York: The Salomon R. Guggenheim Foundation and Horizon Press, 1960. p. 17.

[16] Ibíd. p. 20.

[17] Ibíd. p. 68.

[18] El terrazo fue instalado originalmente en 1959 por la empresa contratista V. Foscato Inc. de Long Island City.

Chusid, Megan. Op. Cit.

[19] La exposición se realizó en el MoMA de New York entre el 23 de mayo y el 13 de agosto de 1991.

[20] Adams, William-Howard. Roberto Burle Marx: the unnatural art of the garden. New York: MoMA-The Museum of Modern Arte, 1991. 


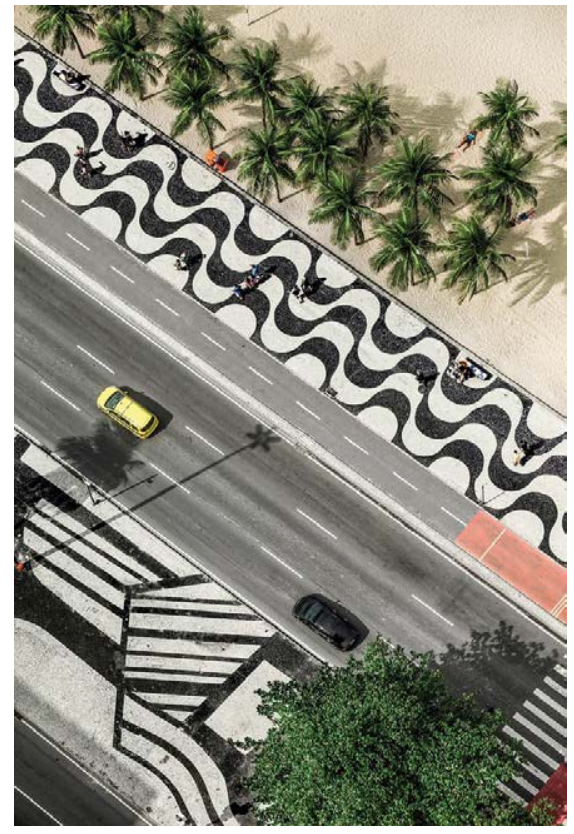

Figura 24.

Pavimentos en el Paseo de

Copa Cabana, en Río de

J aneiro, Brasil (1970). Roberto

Burle Marx. [Fuente: @SF]

[21] Palazuelo de la Peña, Pablo. «Los trabajos y las obras de Brandón» (Escrito redactado en La Peraleda, Galapagar). En: Brandon. Madrid: Galería Montenegro, 1982.

[22] Palazuelo de la Peña, Pablo y Power, Kevin. Geometría y visión. Una conversación con Kevin Power. Granada: Diputación Provincial de Granada, 1995. pp. 76-77.

[23] «Su gran capacidad de invención plástica le indujo a expresarse en otros campos más allá del caballete: concibió decorados para teatro, murales de cerámica, bajos-relieves de hormigón,

esculturas, tapicerías. Atraído por la fabricación de objetos de la vida cotidiana, ajenos al mercado convencional del arte, diseñó manteles, telas estampadas, joyas, almohadones, objetos de vidrio, motivos para vitrales,...

Con imaginería vigorosa desarrolló una técnica de arreglos florales, suerte de mini-jardines que recuerdan el arte de los ikebana: reuniendo diversos elementos - flores, frutas, hojas, piedras, plumas, ramas, espigas, verduras, semillas, maderas y cañas pintadas-, los disponía armoniosamente en un espacio capaz de suscitar tanta emoción como un paisaje o un jardín. En estas pequeñas obras, Burle Marx se manifestaba a la vez como escultor y jardinero»

Iris Montero, Marta. Burle Marx. El paisaje lírico. Barcelona: Editorial Gustavo Gili, 2001. p. 36.

[24] Ibíd. p. 36.

[25] Ibíd. p. 4, 36.

[26] Zevi, Bruno. «Architettura paesaggistica brasileira di Roberto Burle Marx». En: Catálogo de la exposición. Roma: Galleria Nazionale di Belle Arti, 1957.
"Déjeme volver a esta frase de Paul Klee cuando nos habla de "una línea que sueña". La línea ve y abre nuestra visión, pero, al mismo tiempo, nuestra capacidad de ver de esa manera aumentada, impulsa la visión de la línea. [...] La línea puede hacer visible lo invisible. La línea sería vehículo de energías que proceden del trasfondo de la materialidad. La energía toma cuerpo, forma, para conformar el mundo. El artista traza las líneas — vuelve a soñar con aquellas energías- que son las huellas de aquel acorde» [21].

«La geometría está en el origen de la vida, que es lo más inventivo e interminable que conocemos. Tener una visión de las estructuras que se hallan contenidas en otras estructuras, ver las formas nuevas en potencia, ver las posibilidades de generar otras formas, de experimentar el paso de unas formas en otras a través de las metamorfosis, ver lo que crece como una planta. [...] La geometría me parece central porque es la medida de la materia. Medir es un modo de explorar, y se explora para tratar de conocer lo desconocido» [22].

En algunas de sus intervenciones, Burle Marx también incluía mosaicos y esculturas propias. Su rica obra, además de pinturas al oleo, incluye acrílicos o dibujos a tinta china, además de serigrafías, litografías, grabados [23]. Para Lucio Costa: «el trazo [de Burle Marx], ya sea ligero, sostenido, tierno, denso o fogoso, está siempre cargado de significación plástica latente» [24]. Es al mismo tiempo paisajista, músico y pintor. En sus jardines convergen la pintura, la escultura y la arquitectura. Es un músico del cual los acentos se perciben por otro sentido: la vista [25].

Interesado por el arte primitivo y las artesanías locales de la cultura popular, utilizó grafismos pre-colombinos, elementos de los jardines ibéricos que todavía se mantienen en Brasil, o ritmos del arte negro. También recibió la incorporación del agua de la cultura islámica a través de los jardines portugueses - incorporada al espacio público, jardinería y paisaje portugueses desde la dominación islámica. Y los azulejos, heredados del arte persa. Y, desde luego, los mosaicos de los pavimentos portugueses - a su vez heredados de las técnicas romanas- también llamados 'calzada portuguesa'. El adoquinado irregular, de color 'branco' o 'gris', de caliza o de basalto, forma parte del paisaje urbano portugués desde el siglo XIX o más allá. Y son los 'mestres calceteiros', los guardianes de las esencias y de las técnicas de colocación.

Burle Marx, al igual que Dimitris Pikionis, aprovechaba los restos de mármoles o de granitos, provenientes de demoliciones para construir muros, fachadas y pavimentos. Se servía de igual modo de técnicas depuradas con detalles artesanales. Tal vez, su belleza se debe a que en sus obras conviven las decisiones racionales con soluciones heredadas de la tradición popular, uniendo precisión y espontaneidad.

Las trazas de sus pavimentos llevan a muchos críticos a considerarlos como living pictures, como verdaderos cuadros vivos. Pero también es posible reconocer en las pinturas de Burlé Marx, el trazado de jardines y pavimentos. Es posible imaginar las flores de colores vivos dispuestas sobre el suelo, un parterre de tierra o la línea de encintado de un pavimento de adoquín. También las curvas con las que los mosaicos se contonean reconociéndose objetivo de la mirada de los demás, tanto al nivel del suelo como desde otros lugares más elevados. Es posible imaginar cómo la fuerza del viento, traslada las olas del mar a 
las ondas dibujadas en la vereda que bordea el paseo de Copacabana (1970) en $\mathrm{R}$ io de J aneiro, produciendo esas bellas imágenes donde la línea que separa la playa con el suelo pavimentado de calzada portuguesa, queda difuminada por la arena. La propia geometría de las ondas parabólicas - trazadas de forma perpendicular a la dirección del viento- y su orientación, facilitan que las franjas del 'branco' ayude a que se produzca un verdadero efecto de integración en la línea que separa la arena del pavimento, haciendo que el suelo de la ciudad se incorpore a la playa de forma gradual, y que la arena haga lo propio queriendo penetrar en el plano urbano de la ciudad de Rio de J aneiro.

Bruno Zevi consideraba a Burle Marx como 'il massimo paesaggista contemporaneo': «sus jardines son pinturas hechas con plantas que sirven para corregir la arquitectura, humanizarla... La mediación entre la geometría pura de la arquitectura racionalista y las curvas de la frondosa naturaleza tropical se realiza gracias a la experiencia de la pintura moderna» [26].

EI primer encargo importante lo recibe en 1938: un jardín para la azotea del Ministerio de Educación y Salud en Río de J aneiro. Las formas orgánicas, la textura y el uso de colores vivos, introducen el dinamismo en el estático espacio de la azotea. La intervención, destinada a los usuarios del propio jardín, pero también al placer visual de los trabajadores de los niveles superiores, se asemeja a un torrente de un río, donde se pueden reconocer los meandros, los islotes, la ribera e incluso una voluntad por construir un paisaje, mediante el uso del color, formado por unas curvas de nivel.

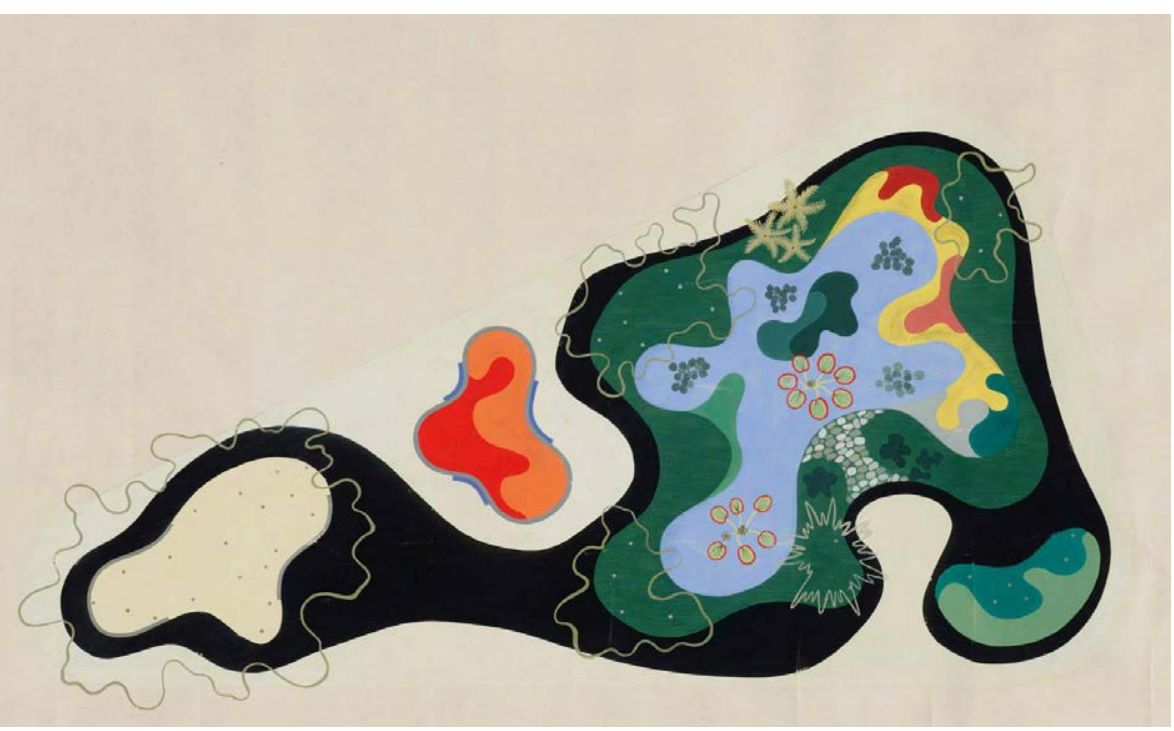

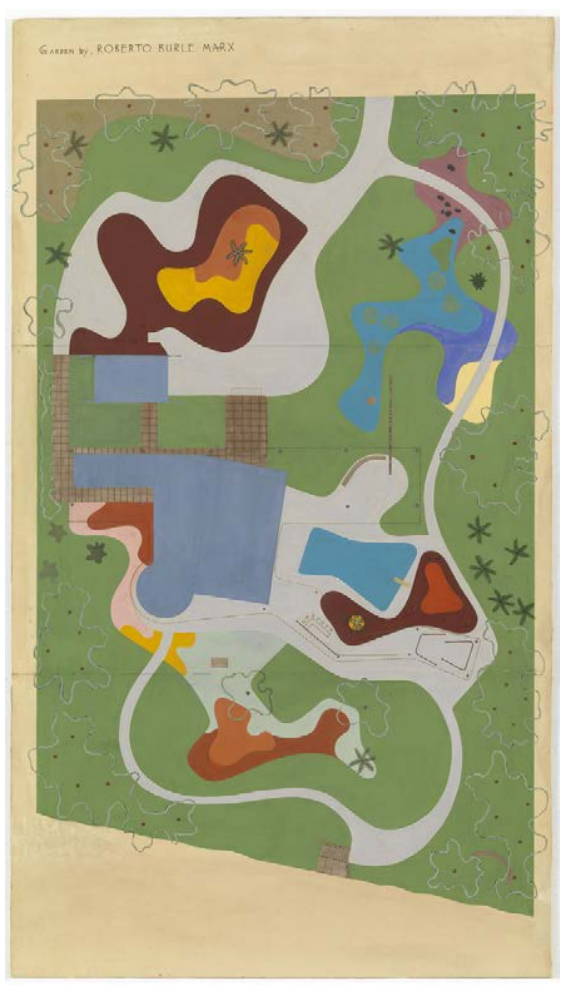

Figura 25. Página siguiente. Garden design for Beach House, Santa Barbara, California (1948). Roberto Burle Marx. [Fuente: OMoMA. Museo de Arte Moderno de New York]

Figura 26

Pavimentos en el Paseo de Copa Cabana, en Río de J aneiro, Brasil (1970). Roberto Burle Marx. [Fuente: CSF]

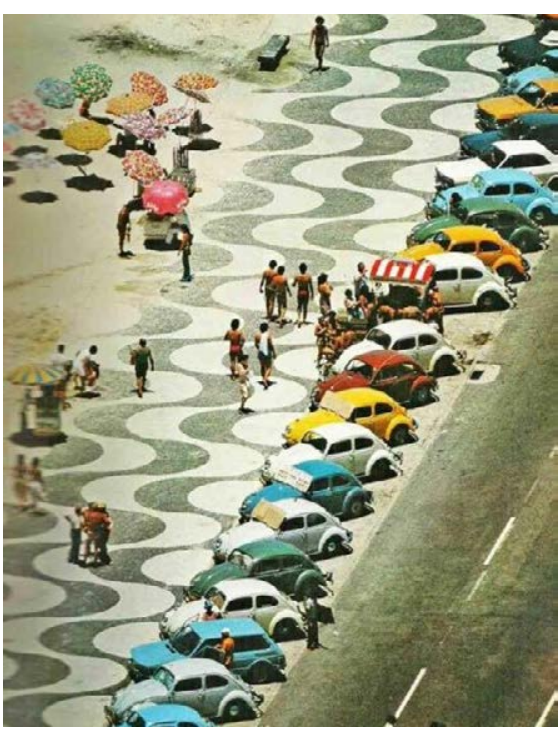




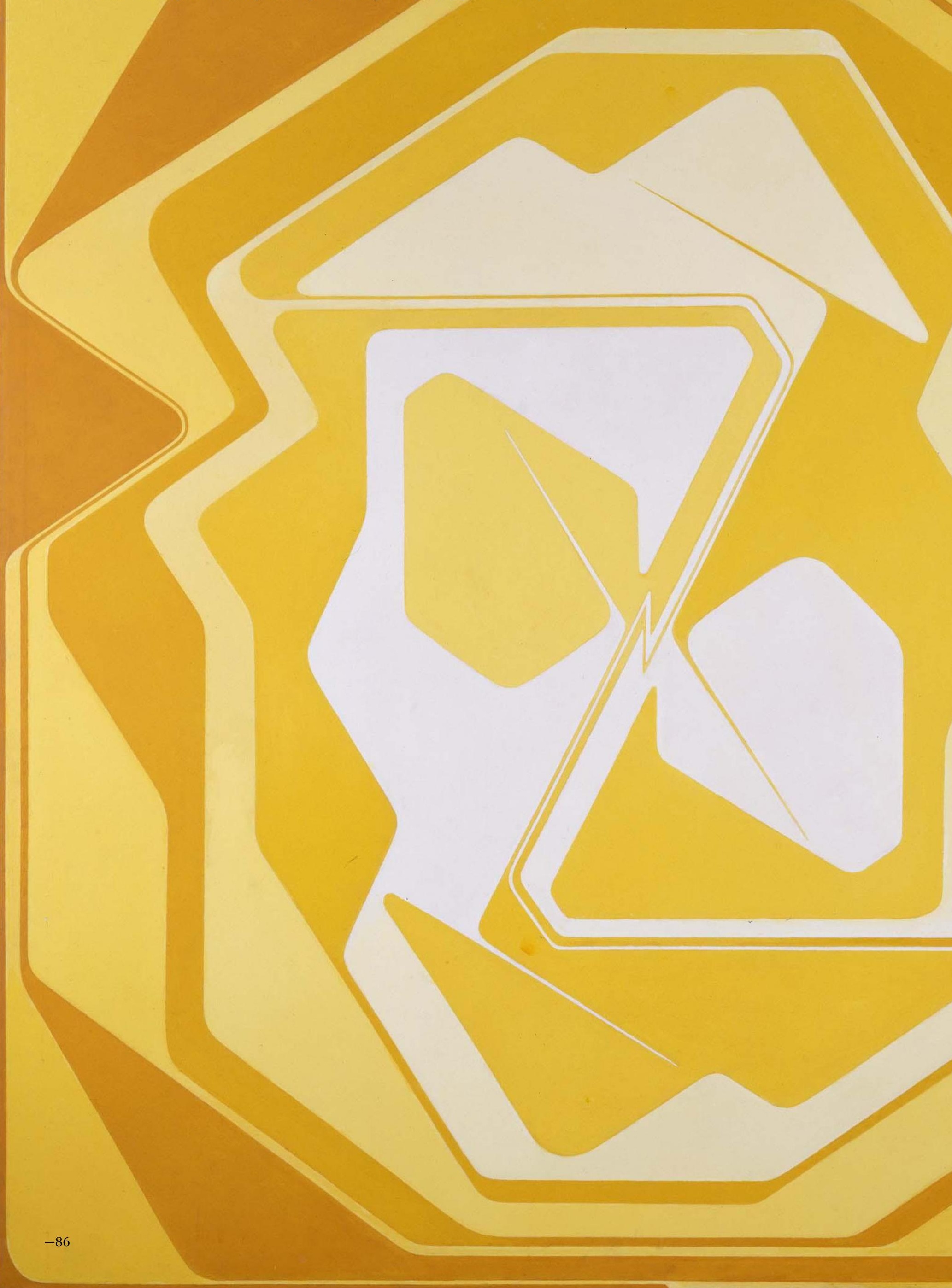




\section{CAPÍTULO 3}

\section{El pavimento en la representación del espacio Perspectiva central y movimiento}

\section{Introducción}

El pavimento es un elemento determinante en la percepción del espacio arquitectónico, debido a su dominio horizontal sobre el campo visual y a la alta proporción de superficie de los espacios que ocupa. Por tanto constituye un elemento esencial en el proceso creativo proyectual. La materialidad, el color, el trazado, el tamaño, el brillo o el patrón geométrico del pavimento contribuyen a impregnar la atmósfera de los espacios de un carácter específico diferente, según el caso. El pavimento puede acentuar algún aspecto de un espacio, ser un reflejo de su contrario el techo, establecer reglas de simpatía con algunos elementos estructurales, o comportarse como un elemento autónomo y endogámico.

Charles-É douard J eanneret-G ris, Le Corbusier (1887-1965) afirmó que de las pocas cosas de las que el hombre es dueño es de su punto de vista situado a $1,70 \mathrm{~m}$ por encima del plano suelo y mirando hacia adelante [1].

«La arquitectura se camina, se recorre y no es de manera alguna, como ciertas enseñanzas, esa ilusión totalmente gráfica organizada alrededor de un punto central abstracto que pretende ser el hombre, un hombre quimérico munido de un ojo de mosca y cuya visión sería simultáneamente circular... La buena arquitectura 'se camina' y se 'recorre' tanto adentro como afuera. Es la arquitectura viva» [2].

«Un plano es, en cierto aspecto, una tabla analítica de materias. Bajo una forma tan concentrada que parece un cristal, un diseño de geometría, contiene una cantidad enorme de ideas y de intención motriz» [3].

\author{
Figura 0. Página anterior \\ Vista del pavimento del \\ Campidoglio en Roma según el \\ diseño de Miguel Ángel / View \\ of the Campidoglio as re- \\ designed by Michaelangelo. \\ Speculum Romanae \\ Magnificentiae (1569). Etienne \\ DuPérac. [Fuente: \\ CUniversidad de Granada. \\ Fondo antiguo / OMET. The \\ Metropolitan Museum of Art, \\ New York. 47.73.2]
}

[1] Le Corbusier (J eanneret, Charles-Edouard). Vers une architecture. París: Saugnier, 1923. Hacia una arquitectura. Barcelona: Ed. Apóstrofe, 1998.

[2] Le Corbusier (J eanneret, Charles-Édouard). Entretien avec les étudiants des Ecoles d'Architecture. París: Les Editions de Minuit, 1957. Mensaje a los estudiantes de Arquitectura. Entretien avec les étudiants des Ecoles d'Architecture. Buenos Aires: Ed. Infinito, 2001. ISBN: 987-96370-3-8.

[3] Le Corbusier (J eanneret, Charles-Édouard). Vers une architecture. París: Saugnier, 1923. Hacia una arquitectura. Barcelona: Ed. Apóstrofe, 1998. p. 145 . 


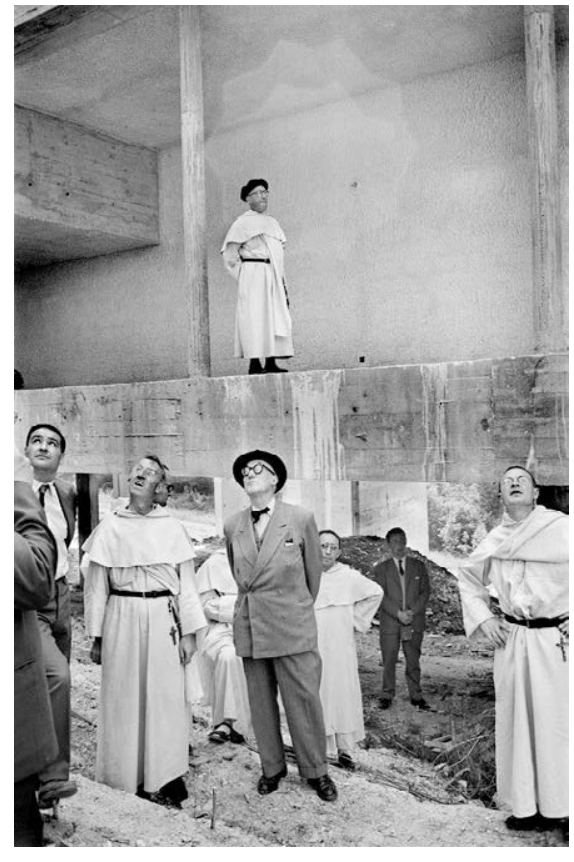

Figura 1.

Le Corbusier inspeccionando

las obras del Monasterio de

Santa María de la Tourette

(1959). [Fotografía: @René

Burri @Magnum Photos.

PAR 85700]

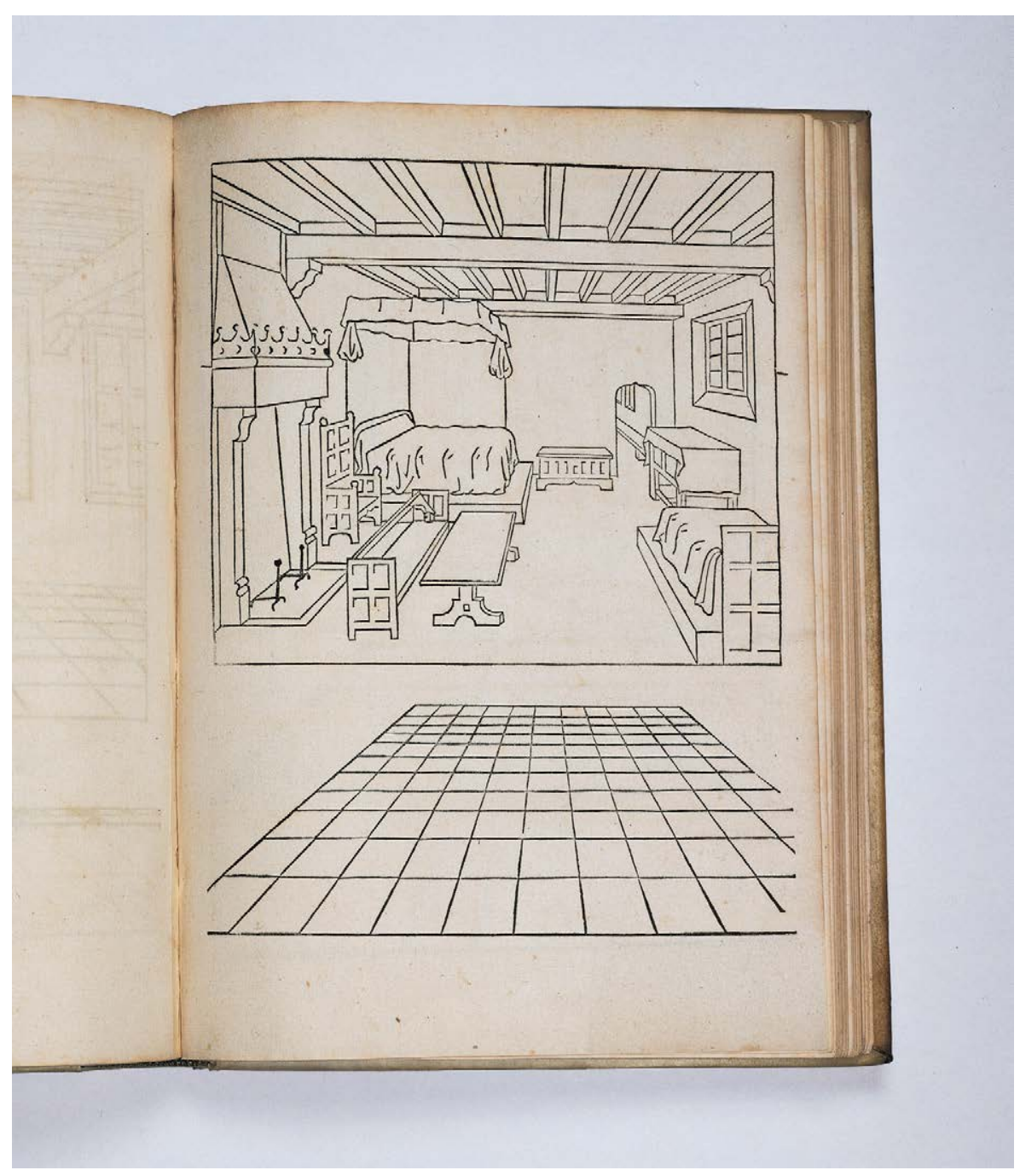

También señalaba: «la arquitectura es un oficio muy difícil, hay que ejercitarlo con constancia, con tenacidad, con humildad; somos asnos dando vueltas al a noria». Y añadía: «pero asnos que ven» [4].

Y es que según J ames J erome Gibson (1904-1979) no hay percepción del espacio sin una superficie continua básica [5]. Y el plano del suelo es una superficie indiscutible e ineludible.

Para un observador puesto de pie, la intersección de su cono visual con el plano del suelo se sitúa a una distancia de 10 metros. Más cerca, el suelo no se percibe desde un punto de vista óptico, sin embargo si lo hace desde un punto de vista háptico. Pero la percepción del espacio no se produce de una forma geométrica exacta, ya que el punto de vista puede cambiar de ángulo, simplemente cambiando de posición la cabeza. Precisamente, ese límite de $10 \mathrm{~m}$ asegura la percepción de los detalles de los objetos y elementos de un espacio, quedando éstos difuminados si están situados más allá de ese límite. Quizá por ello, esa dimensión de 10 m es recurrente en las salas abovedadas de las Villas de Andrea Palladio (1508-1580), ya que tienen $7 \mathrm{~m}$ de altura - o menos.

La altura del horizonte ha sido un dato que, a lo largo de la historia, ha variado según la posición del hombre en cada momento. Por ejemplo, en la Alhambra de Granada, los nazaríes se sentaba sobre el suelo, por lo que su horizonte descendía hasta los $70 \mathrm{~cm}$ sobre el nivel del pavimento. Por ello, la mayoría de 
los huecos y de las ventanas están dimensionados según esta circunstancia. La percepción de la Alhambra es completa cuando se contempla desde el suelo. Cuando se produce la dominación la cultura cristiana sobre la cultura islámica se produce un desplazamiento de la altura del horizonte, y por ello aparecen otros elementos arquitectónicos de protección vinculados a los huecos [6].

Pero antes de ese momento, los paisajes y los espacios interiores en general y el pavimento en particular, se representaba según la perspectiva geométrica centralizada con un único punto de vista. El primer tratado impreso sobre perspectiva: De artificiale perspectiva (1505), de J ean Pèlerin (1445-1524) - conocido como Viator- es una especie de cartilla visual con grabados que representan espacios arquitectónicos interiores, claustros, vistas urbanas o paisajes (fig. 03). A diferencia de otros tratados como el de Leon Battista Alberti (1404-1472) [7], no tiene un fuerte contenido teórico. En la mayoría de las ilustraciones - donde no aparece la figura humana - se representa el plano del suelo como un elemento aislado y situado debajo del recinto dibujado. Estas rejillas que representan el pavimento - dibujadas con trazos elementales y cuyas líneas convergen en un único punto de fuga - contribuyen eficazmente a la comprensión de la profundidad del espacio arquitectónico. Los techos, cuyo sistema

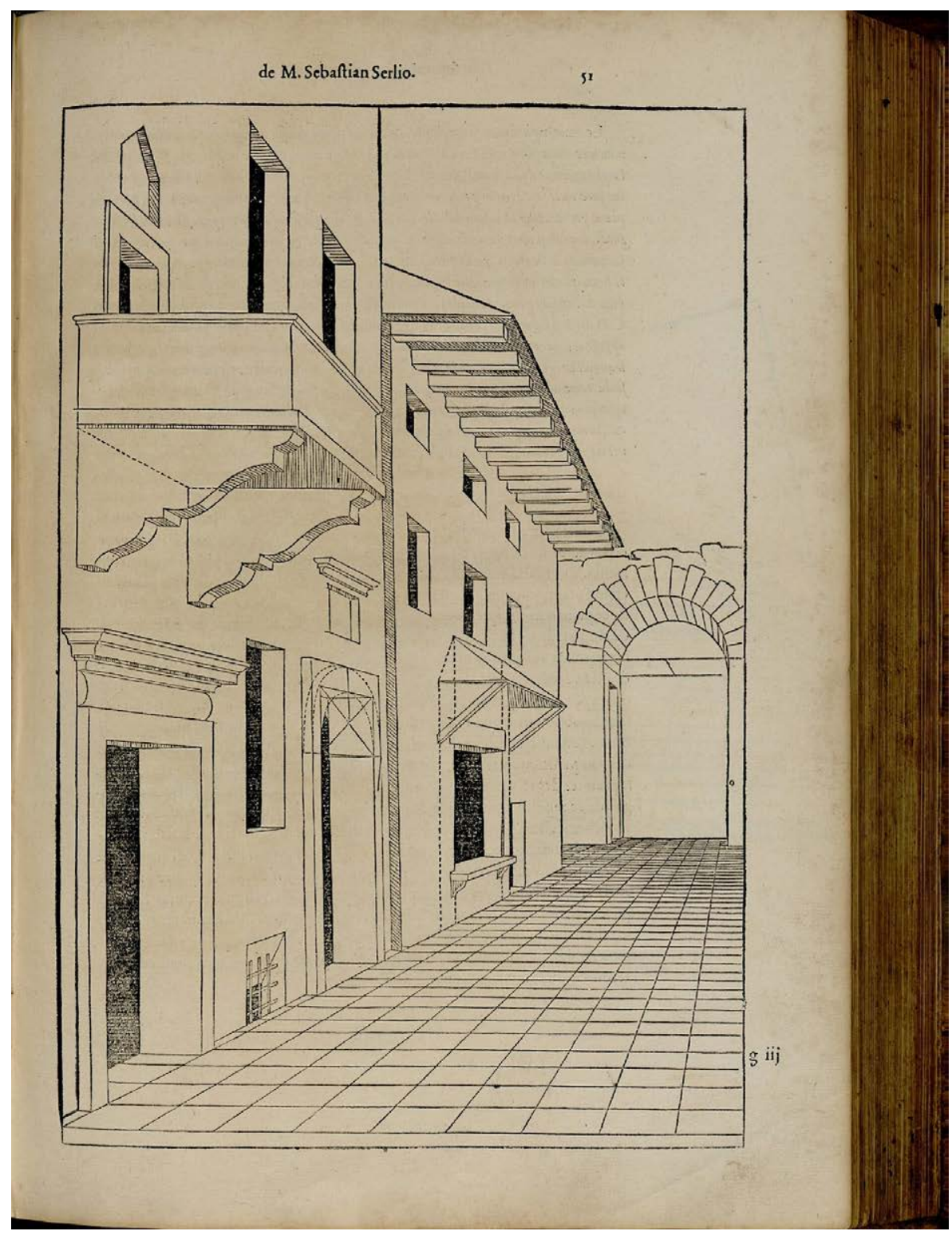

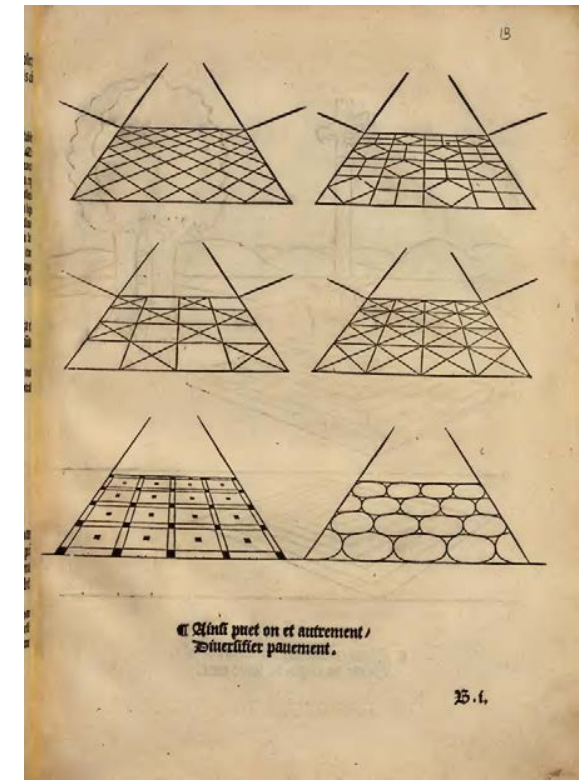

Figura 3 Ilustración de las rejillas de pavimento. De Artificiali Perspectiva (1521). J ean Pèlerin / Viator. [Fuente: CBibliothèque Nationale de

France]

Figura 4.

llustración del pavimento de un ámbito exterior. // Secondo libro di Persepettia [...]; Le Second livre de Perspective [...]. p. 111. Premier, second, troisième, quatrième et chiquième livres d'architecture de Sébastien Serlio Bolognios (1545). Sebastiano Serlio. [Fuente: CBibliothèque de I'Institut National d'Histoire de l'Art, collections J acques Doucet NUM 4 RES 1476]
[4] Le Corbusier (J eanneret, Charles-Édouard). Vers une architecture. París: Saugnier, 1923. Hacia una arquitectura. Barcelona: Ed. Apóstrofe, 1998.

[5] Gibson, J ames-J erome. La percepción del mundo visual. Buenos Aires: Ediciones infinito, 1974.

[6] Palacios-Díaz, Dolores. «Cuerpo, distancias y arquitectura. La percepción del espacio a través de los sentidos». Directores: Antonio Miranda-Regojo y Nicolás-Maruri González de Mendoza. Madrid: Universidad Politécnica de Madrid, Escuela Técnica Superior de Arquitectura, Departamento de Proyectos Arquitectónicos, 2014.

[7] Alberti, Leon Battista. De Re Aedificatoria (1452). Madrid: Ediciones Akal, 1992. 


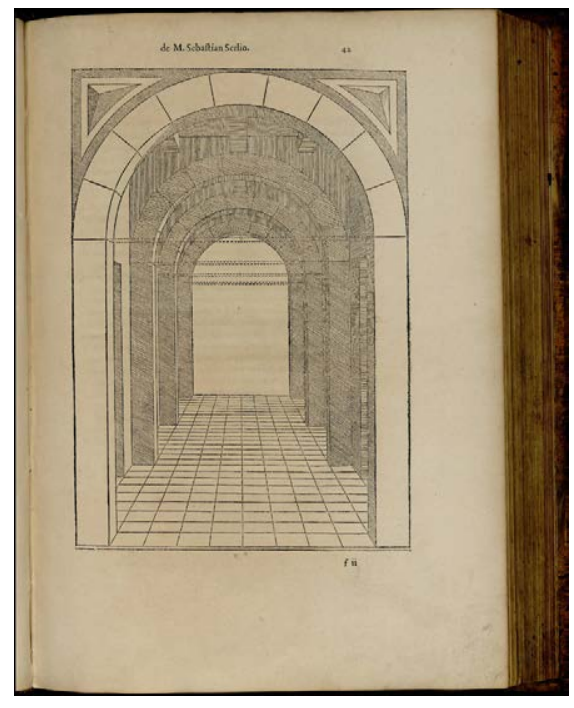

Figura 5 .

llustración del pavimento de un ámbito exterior. II Secondo libro di Persepettia [...]; Le Second livre de Perspective [...]. p. 93. (1545). Sebastiano Serlio. [Fuente: CBibliothèque de I'Institut National d'Histoire de l'Art, collections J acques Doucet. NUM 4 RES 1476 constructivo de la cubierta se hereda de forma visible en forma de vigas y nervios, quedan lo suficiente definidos, siendo en muchas ocasiones un reflejo horizontal de su opuesto.

Sin embargo es el plano inferior del suelo, sobre el que se apoya el mobiliario y el ajuar, donde la representación de la profundidad se reconoce más comprometida. Como se puede ver en el tratado Second livre de perspective (1545) de Sebastiano Serlio (1475-1554) en distintos ejemplos, tanto de espacios cubiertos, galerías o vistas urbanas. Estos principios se manifestaron primero en la Italia del siglo XV y luego en el resto de Europa [8]. Un ejemplo de esto ocurre en el primer episodio de la predela Micarolo dell'ostia profanata / El milagro de la hostia profanada (1467-1468) de Paolo Ucello (1397-1475), a diferencia de que aquí si aparecen dos figuras humanas, y donde encontramos un pavimento de geometría sencilla y una techumbre donde las vigas de madera convergen en el único punto de fuga de la representación.

En la perspectiva geométrica centralizada, la libertad para situar la línea del horizonte establecía más o menos protagonismo al plano del pavimento, convirtiéndolo en el único territorio geometrizable del que disponía el creador. Los tratadistas y artistas del Renacimiento también tenían contemplada la representación del paisaje, entendiendo el plano natural como una tierra pavimentizable [9].También J ean Pèlerin (Viator) ofreció distintos ejemplos, en la segunda edición de su tratado donde, mediante una línea diagonal y varias horizontales, que disminuían la separación con la profundidad, se representaba en la tierra un 'pavimento subyacente' [10].

Así, en muchas pinturas del Renacimiento, el plano del suelo se organiza y ordena para sugerir la profundidad mediante el establecimiento de un horizonte y de unas líneas de fuga. Es el caso de la pintura la Batalla de San Romano de Paolo Uccello (1397-1475), donde la disposición de las lanzas en el suelo - formando un pavimento virtual-, impregnan de profundidad la obra que, de otro

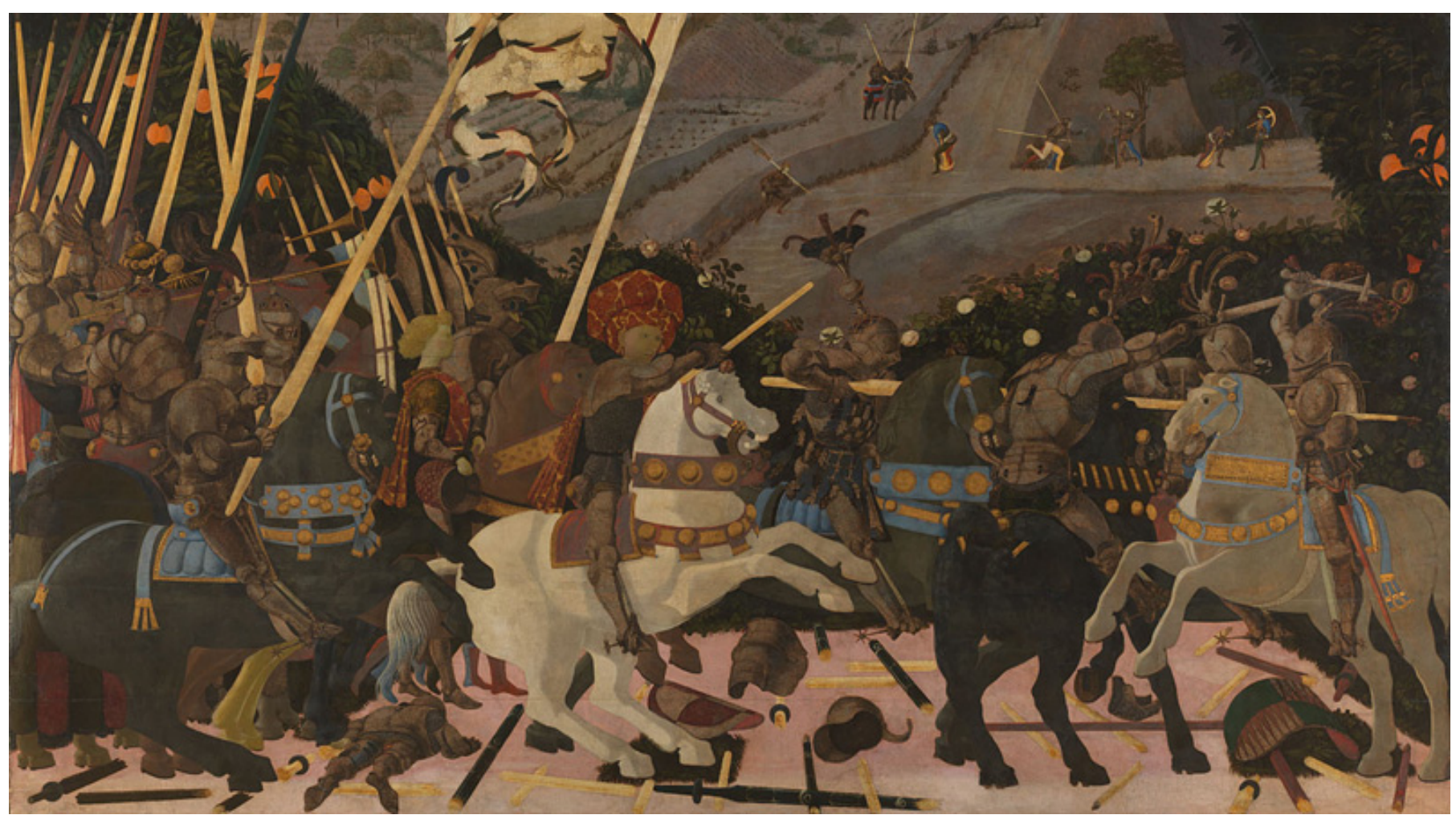




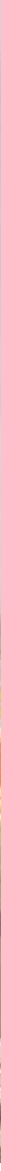

modo, y al disponer de un suelo liso, no se produciría (fig. 04 y 05). Un poco posterior, también encontramos este método en el cuadro The tulip folly de J ean-León Gérôme, donde un campo de tulipanes de distintos colores, aprovechan las líneas de separación de los bancales, para representar la profundidad, produciendo un suelo, al que podemos considerar también un manto vegetal pavimentado.

Así, esta relación entre el plano vertical del cuadro y la línea del horizonte de la tierra, es el tema central de la gran mayoría de las obras más representativas del Renacimiento que se extendieron por Europa, con el germen italiano, a la vez que penetra la cultura figurativa del Renacimiento [11].

Albrecht Dürer (Durero) (1471-1528) utilizaba la técnica del cuadriculado (Máquina de perspectiva, inventada por Leonardo). Entre él y el modelo, colocaba una retícula de hilos de alambre. La misma retícula, pero dibujada sobre la mesa, reproducía los puntos de referencia para fijar, con cierta precisión, las trazas características. Este método, que se apoyaba en la rejilla vertical y que permitía el dibujo sobre las trazas geometrizadas del plano horizontal, está permanentemente presente en la cultura figurativa desde el quattrocento [12].

En El Claustro verde de Santa María Novella de Florencia, de Paolo Ucello, el pintor lleva al plano vertical del muro - donde está pintado- algo que en principio se supone que pertenece al ámbito del suelo o al del techo.

En el cuadro la Adoración de la Cruz y El encuentro de Salomón con la reina de saba (1455-1458), de Piero della Francesca (1416-1492), el techo y el suelo se reparten, casi de forma simétrica, pero también especular, el protagonismo de la perspectiva. Así, en el lado derecho del cuadro es el techo - ante la ausencia del suelo, al estar cuajado de personajes - el que produce la profundidad, y en el lado izquierdo es el suelo - ante la ausencia de techo, al estar al aire librequien se encarga de incorporar la perspectiva. Así, según recoge J uan Antonio

[8] Ramírez-Domínguez, Juan-Antonio. «Pavimento, suelo, tierra (de promisión)». En: Fernández Polanco, Aurora (ed.). Cuerpo y mirada, huella del siglo XX. Madrid: Museo Nacional Centro de Arte Reina Sofía, 2007. pp. 65-87.

[9] Ibíd. pp. 135-162.

[10] Ibíd. pp. 135-162.

[11] Ibíd. pp. 65-87.

[12] Ibíd. pp. 65-87.
The tulip folly (c1882) León Gérôme. [Fuente: OThe Walters Art Museum, Baltimore. 37.2612] 


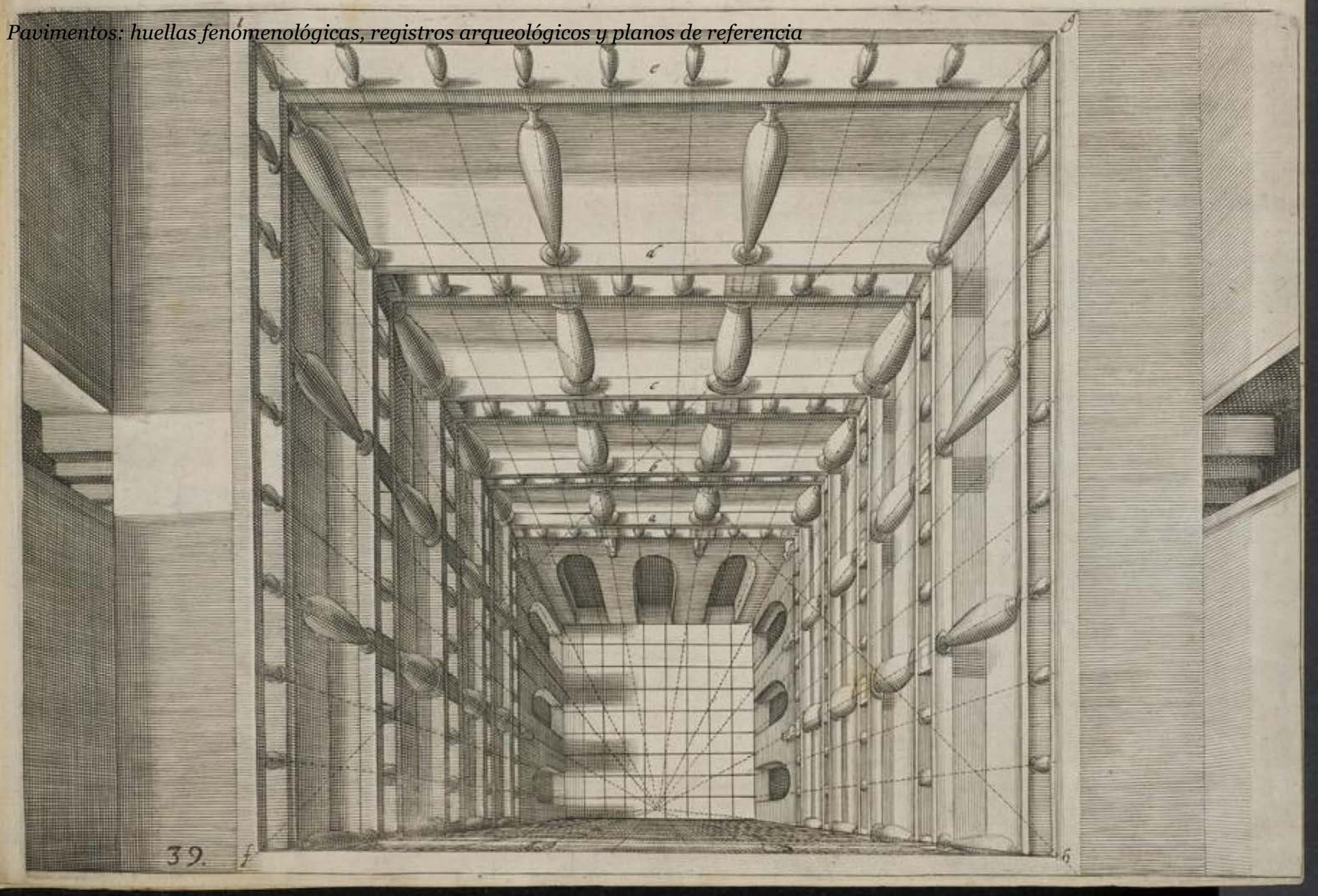

Figura 8.

Perspectiva (1604). J an

Vredeman de Vries. [Fuente:

CDüsseldorf: Universitäts- und

Landesbibliothek]
[13] Ramírez-Domínguez, J uan-Antonio. «Pavimento, suelo, tierra (de promisión)». En: Fernández-Polanco, Aurora (ed.). Cuerpo y mirada, huella del siglo XX. Madrid: Museo Nacional Centro de Arte Reina Sofía, 2007. p. 68

[14] Pozzo, Andrea. Perspectiva pictorum atque architectorum / Prospettiva de Pittori e Architetti / Perspectiva para pintores y arquitectos. Roma.

[15] Martínez Santa-María, Luis. El libro de los cuartos. Madrid: Editorial Lampreave, 2011. p. 125.

[16] Molina-Rodríguez, Santiago de. «Habitaciones sin aristas pero con rincones». Múltiples estrategias. Madrid: Ediciones asimétricas, 2015.

[https:/ / www.santiagodemolina.com/ 2018/ 10/ hab itaciones-sin-aristas-pero-

con.html?fbclid=IwAR0jy7oM9k9ABeH_CSdnQWj

Y7KeIEMbYniU-ITYjvDqcvliOAJ sjBISiDīM]

(05/ 11/2018).
Ramírez: "podemos considerar esta especie de relación entre la parte superior y la parte inferior de la caja espacial como un motor oculto del arte de la edad moderna» [13].

Otros tratadistas, como J an Vredeman de Vries (1527-1607) nos muestra, en un grabado de su libro Perspectiva (1604-1605), un punto de vista imposibles para el ojo humano como la vista cenital de un patio - casi como una imagen vista desde el firmamento por un ángel o Dios. Que por otro lado, es el modo eficaz y técnico de representar el pavimento, ya que entre otros motivos, se representa en verdadera magnitud, sin deformaciones.

La 'planta' es el documento predominante en la definición de la arquitectura. Y desde luego en la definición de los pavimentos, ya que la analogía en la posición de la planta de pavimentos y del tablero de dibujo o la hoja de un papel, hace que sea la proyección ortográfica más lógica. Además, en la 'planta' se puede presagiar la sección y el alzado, pero también el techo que la cubre. Ella es heredera universal de los cimientos y es depositaria de las trazas de los muros y de la posición de los pilares. En ella se define la geometría, el despiece y la materialidad de los pavimentos, pero también es portadora de la definición de la estructura y de la materialidad de los paramentos.

Andrea Pozzo (1642-1709), autor de un tratado del Barroco sobre perspectiva [14], proporciona un método para dibujar correctamente los techos abovedados. Se trata en una transposición desde la rejilla del pavimento hasta la superficie curva del techo.

Heinrich Tessenow (1876-1950) fue un arquitecto con una obra relativamente modesta. Y sin embargo, se convirtió en uno de los arquitectos más importantes de su época, tanto por su obra, como por sus escritos y sobre todo por sus 
dibujos. Sin embargo ha sido relativamente olvidado por la historiografía - o historiografías- del Movimiento Moderno. Su trabajo no intentaba ofrecer una alternativa a la modernidad, sino que demostraba cuánto la modernidad estaba profundamente conectada con la tradición.

Con todo, sus dibujos todavía hoy emocionan. Son perspectivas sencillas, elaboradas bien por la acumulación de puntos - con los que también formaba las líneas - como por la acumulación de líneas - que finalmente formaban las manchas de sombras- Por lo tanto es el punto el elemento que repetido, una y otra vez, construye sus atmósferas habitadas. Uno de sus contemporáneos, Paul Klee (1879-1940) lo expresaría así: «Una línea es un punto que camina». También Charles-É douard J eanneret-G ris Le Corbusier (1887-1965) se servía de los puntos y de los trazos de rayitas en la representación de sus perspectivas exteriores e interiores:

«En los bellos dibujos que realizó durante toda una época aparecen interiores dadivosos. Una alfombra convive con una doble altura, con una botella de vino, con un piano, con un par de sillas de mimbre, con un boxeador, con una mujer hacendosa, con un perro. Un conjunto armónicamente revuelto en una familiaridad profunda. Pero de todo lo que vibra en estas representaciones hay que subrayar esa muchedumbre de rayitas y puntitos. Es lo que te rinde. Incontables arañazos que este arquitecto fue dejando por las paredes y por los suelos, y por todos los recovecos, como para manifestar que estaba seguro de que la arquitectura moderna también sería capaz de conseguir crear la atmósfera de un hogar de verdad» [15].

Aunque también dibujó perspectivas exteriores, son los interiores austeros, donde el único añadido era la hermosa luz y el ajuar imprescindible, donde consiguió construir unos dibujos sublimes. En las representaciones de los cuartos, las habitaciones y los espacios se entremezclaba la vida cotidiana con la precisión del trazado del pavimento. Casi nunca dibujaba figuras humanas. No hacía falta. Una puerta entreabierta - esperando una llegada inminente o anunciando una despedida reciente- además de su propia presencia como dibujante, colmaban los dibujos de humanidad. El hombre estaba presente en la representación de: las alfombras, los retratos colgados de las paredes, los relojes, las cortinas, los espejos, los pasamanos de madera de las escaleras, los rodapiés, las sillas de anea, o de una maceta en el alféizar de una ventana. Todo ello insistía en la obligación de describir lugares habitados. Pero lo que importaba de verdad, el tema central de sus dibujos, era la ausencia de lo que no estaba dibujado [16].

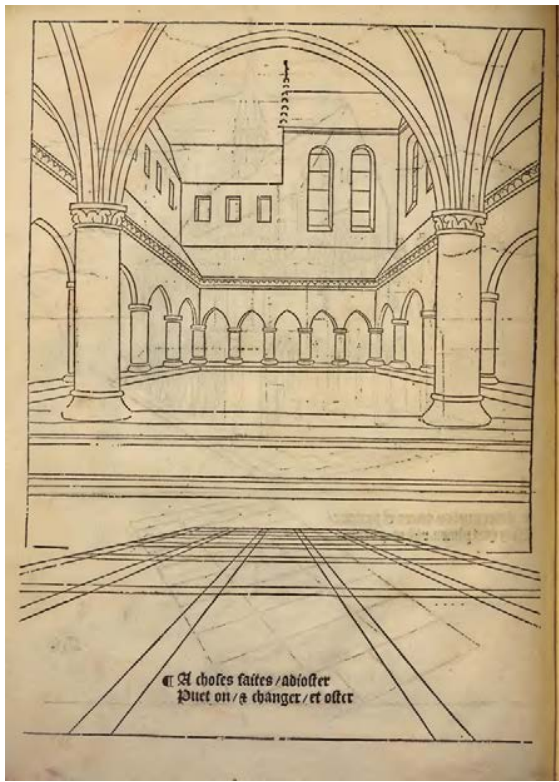

Figura 9.

De artificiali Perspectiva (1501) J ean Pèlerin / Viator. [Fuente: CB ibliothèque Nationale de France]
Figura 10

Draughtsman Making a Perspective Drawing of Reclining Woman (c1600). Albrecht Dürer. [Fuente: CMET. The Metropolitan Museum of Art. New york. 17.37.314]

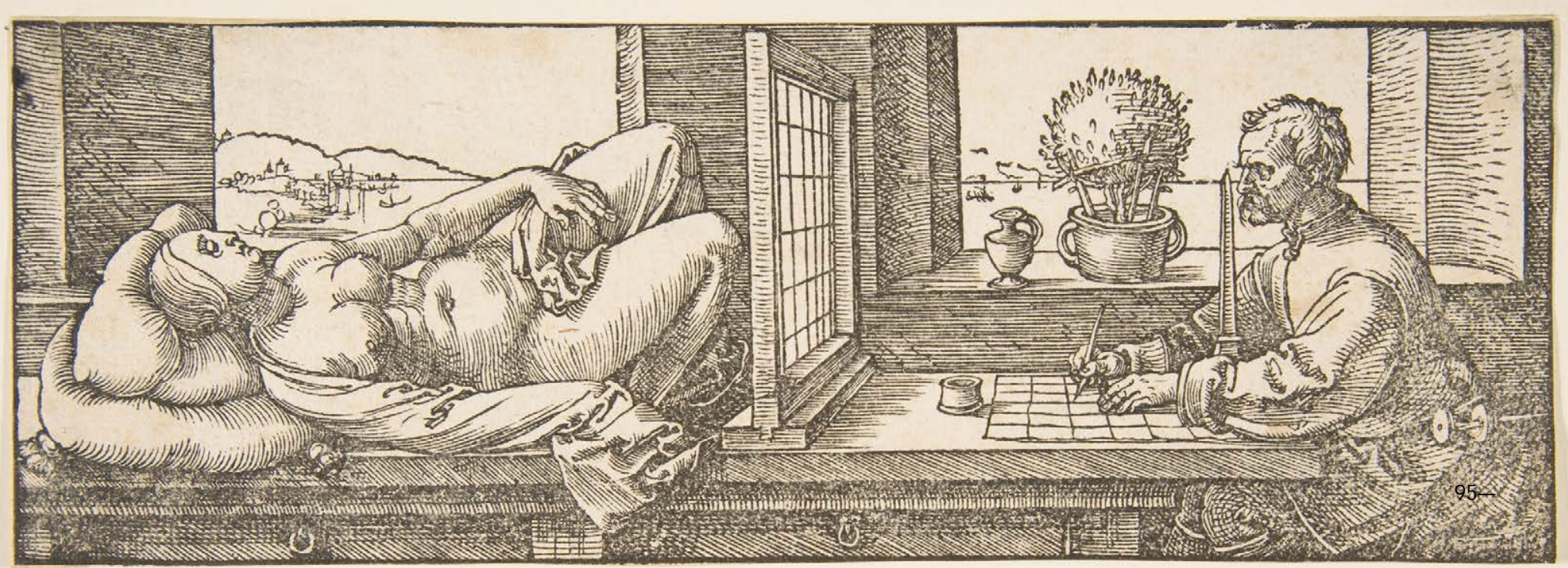


Figura 11. Perspectiva interior extraida del libro Hausbau Und Dergleichen (1916). Henri Tessenow. [Fuente: OUniversity of Toronto]

Figura 12.

Perspectiva exterior extraida

del libro Hausbau Und

Dergleichen (1916). Henri

Tessenow. [Fuente: OUniversity

of Toronto]

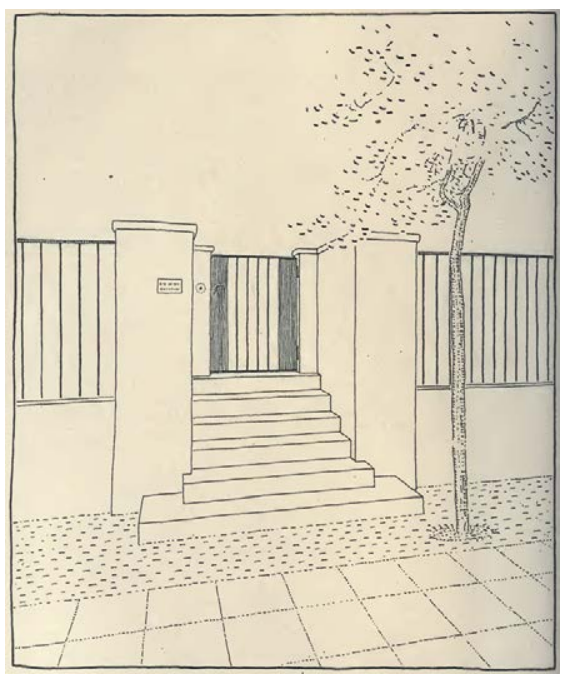

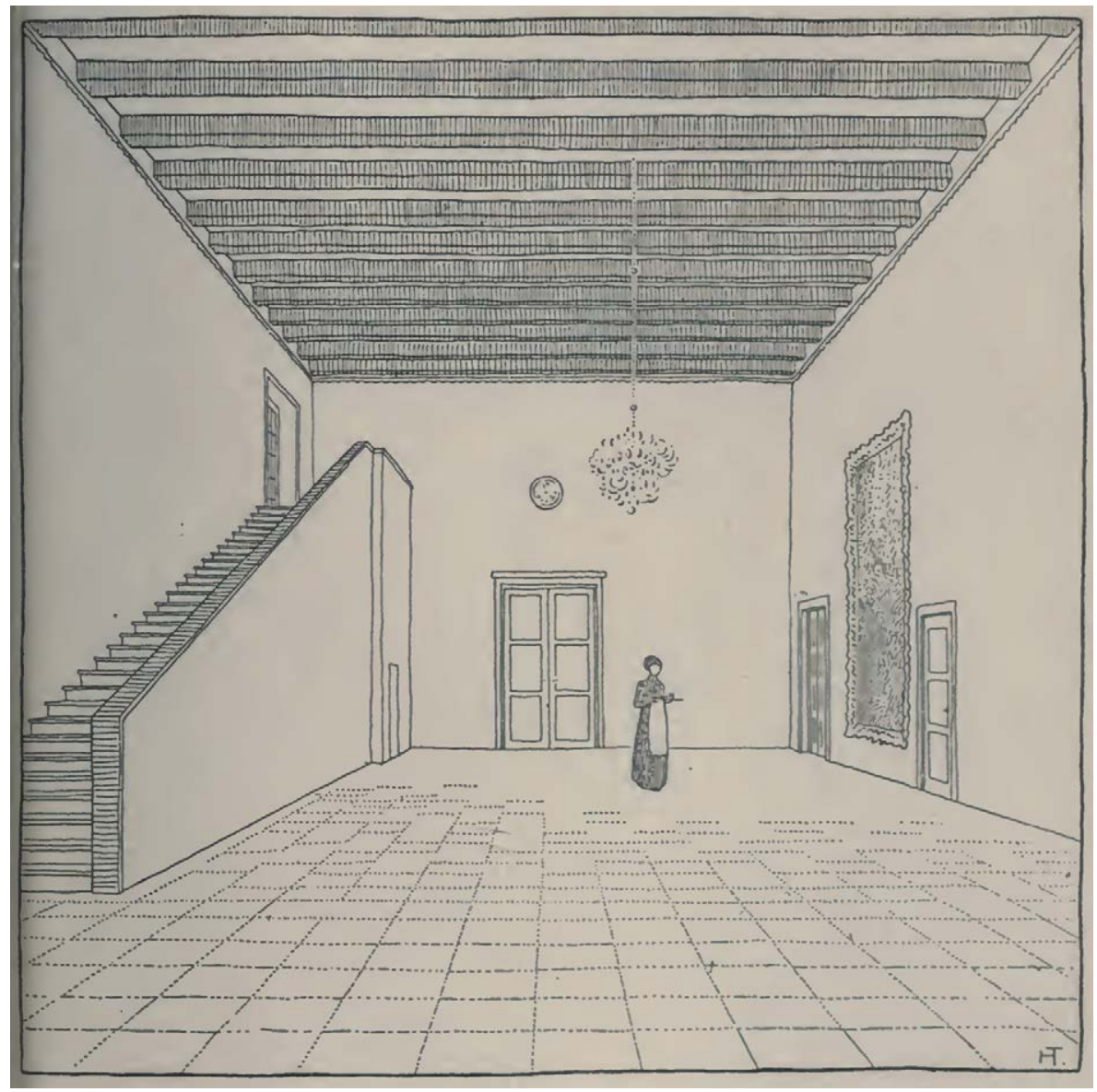

Aunque hacía uso de la perspectiva frontal con un único punto de fuga, predominaban las vistas en escorzo. También dibujaba algunas vistas interiores en las que el punto de vista era casi completamente frontal, pero se producía una leve desviación al estar desplazado, produciendo que las líneas del pavimento del suelo, o las del hipotético techo, no fueran exactamente paralelas al recuadro de cada dibujo, este elemento sí, siempre presente. Esta circunstancia de evitar la perspectiva centralizada le otorgaba al dibujo, además de la humanidad del error intencionado, una apariencia de cierta modestia en los medios.

Heinrich Tessenow se recrea en los rincones de las casas: es decir, en esos lugares que reúnen todos los requisitos para convertirse en un hogar habitado. Las ventanas, convenientemente adornadas por visillos, cortinas o macetas, no son sólo una perforación en el muro por las que entra luz, sino que el autor ha decidido que éstas no arrojen sombra sobre el suelo, ni diferencien ninguna pared por su luminosidad. En esos interiores, las ventanas se encargan de iluminar de forma constante, con una luz neutra, blanca y universal [17]. Hay dos excepciones: una vista de una puerta de entrada, y la escalera.

A veces, no representa las aristas de las esquinas de las paredes [18], confiando - en la disposición de los muebles o en los espejos a poyados sobre ellasel método para conseguir definir la espacialidad. Donde sí se recreaba era en la elaboración de los pavimentos del suelo. Es en el plano horizontal donde depositaba casi el único ornato del dibujo, ya que el resto de superficies se sirven del color del papel como único fondo.

A parecen pavimentos formados por losetas de formato cuadrado, pero también suelos entarimados de madera, representados a veces sólo con las juntas entre 
las tablas de madera - en una sola dirección- y otras veces se recrea en dibujar las vetas de la madera- En ocasiones, una alfombra cubre un fragmento del suelo, con la voluntad de fundar un lugar para situar una mesa o una cama, o para bordearla esperando que unos pies se encuentren una superficie cálida durante el frío invierno al salir de la cama; pero en otros dibujos, la alfombra es el único elemento dispuesto sobre el suelo yermo de geometría. En algún caso extremo, Heinrich Tessenow renuncia a dibujar ni las aristas que unen los planos de las paredes, ni las que unen éstas con el plano del suelo, al que tampoco representa con ninguna línea o dirección. Se trata de un continuum de material - o la ausencia de éste- que invade todas las superficies de los cuartos. Pero el laconismo en la representación de los dibujos tiene la habilidad de permitir poner en valor la presencia en las ausencias: las cualidades de cada material, su apariencia, su color o su brillo. Incluso permiten imaginarse las paredes que no vemos, el techo que no se percibe o el suelo que no se dibuja. A pesar de ser fragmentos de una casa, en ellos reside todo cuanto una casa aspira a ser.

Cuando dibuja la rejilla del pavimento, muchas veces se convierte en un sistema de referencias, tanto para la posición de algún mueble, como cuando señala la posición de algún felpudo o elemento estructural. Así ocurre en una vista frontal de un acceso a una vivienda. En este caso, además, las juntas de las losetas del pavimento, a veces, las delinea con un trazo discontinuo. Esto no ocurre sistemáticamente, sino de forma aleatoria, lo que le confiere al dibujo

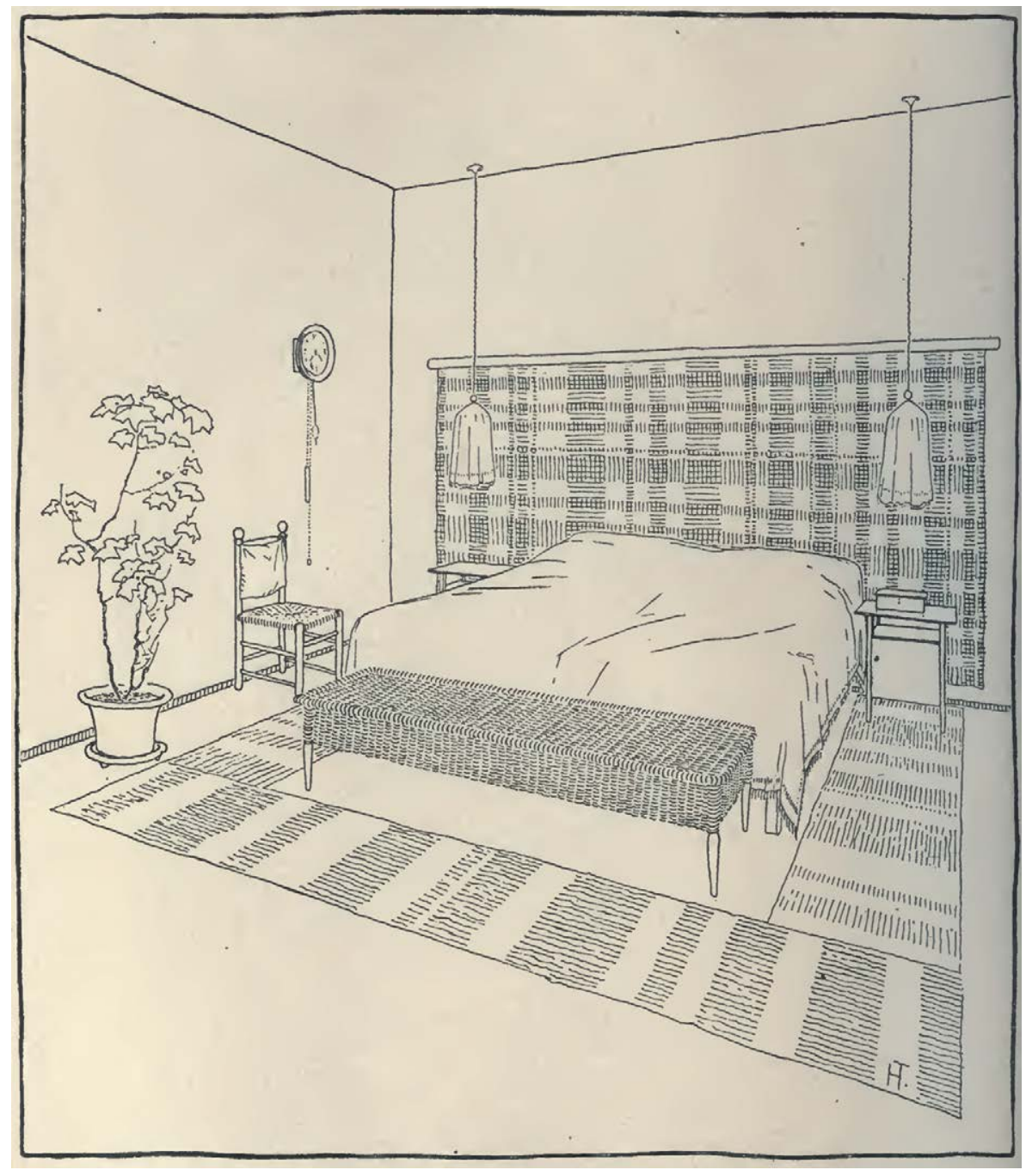

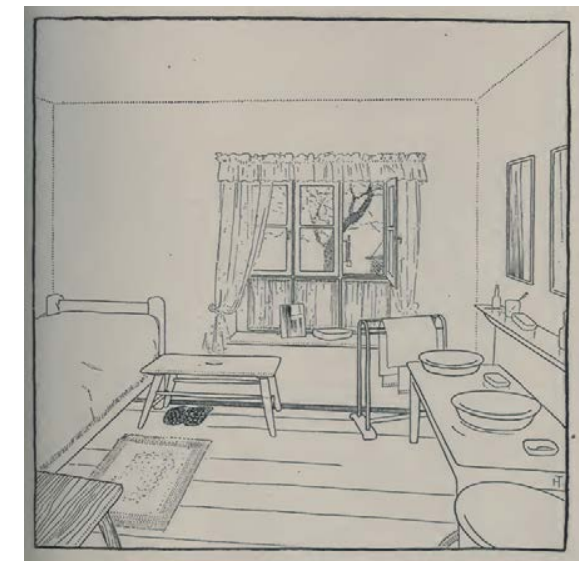

Figura 13. Perspectiva interior extraida de libro Hausbau Und Dergleichen (1916). Henri Tessenow [Fuente: CUniversity of Toronto]

Figura 14.

Perspectiva interior extraida del libro Hausbau Und Dergleichen (1916). Henri Tessenow.

[Fuente: CUniversity of Toronto]
[17] Molina-Rodríguez, Santiago de. «Habitaciones sin aristas pero con rincones». Múltiples estrategias. Madrid: Ediciones asimétricas, 2015. [https:// www.santiagodemolina.com/ 2018/ 10/ hab itaciones-sin-aristas-pero-

con.html?fbclid=IwAR0jy7oM9k9ABeH CSdnQWj Y7KeIEMbYniU-I7YjvDqcvliOAJ sjBISiDiM] (05/11/2018).

[18] Ibíd. 


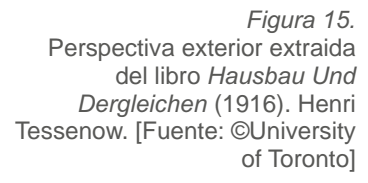

Figura 16

Perspectiva interior extraida de

libro Hausbau Und Dergleichen

(1916). Henri Tessenow.

[Fuente: CUniversity of Toronto]

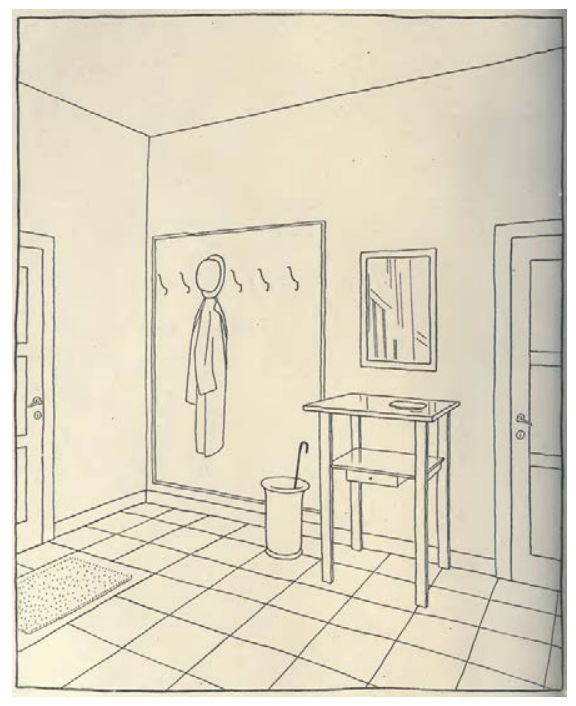

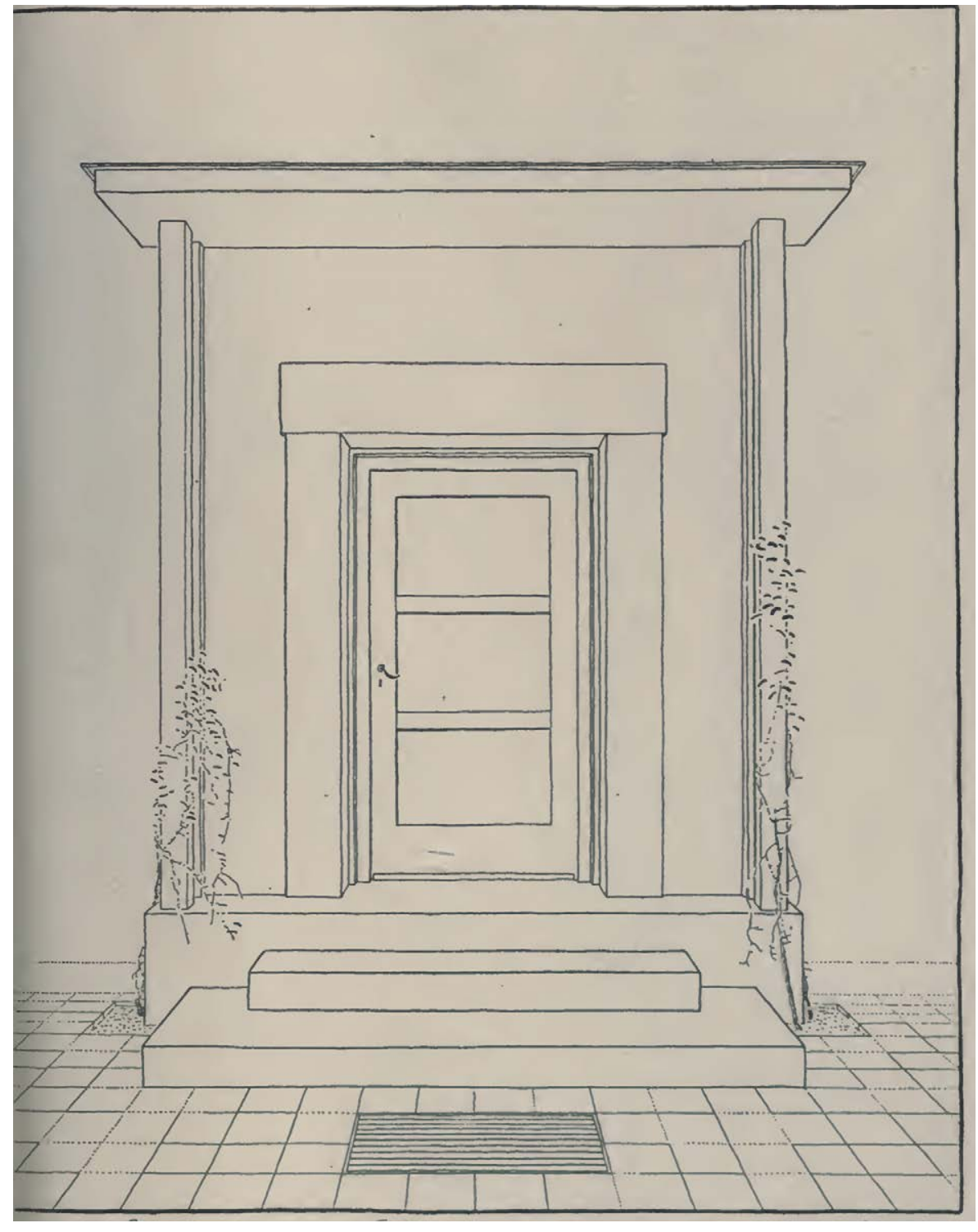

una apariencia de imperfección realista. Esto también sucede, aquí sí de forma sistemática, cuando las trazas del pavimento, en las zonas alejadas, bien se convierten en líneas discontinuas o bien desaparecen. Esta técnica, por un lado refuerza la idea de profundidad, pero por otro, introduce un brillo sobre la superficie del pavimento.

Para Tessenow todas las arquitecturas, independientemente de su escala 0 función, parten de la noción de vivienda (wohnen); y deben construirse mediante las complejas relaciones entre modernidad y tradición, industria y artesanía, normalidad y familiaridad o abstracción y composición [19].

«Que el objeto lejano parece menor porque lo percibimos desde un ángulo visual más pequeño, es una burda creencia que debía hundirse en las sombras, por lo menos en arquitectura» [20].

A lo largo de la historia de la pintura, se ha utilizado la perspectiva invertida para la representación de objetos y elementos cercanos. Por ejemplo, en la perspectiva bizantina, los objetos empequeñecen su tamaño al acercarse al observador. De ese modo, la perspectiva se fuga hacia el ojo del espectador. En los mosaicos de San Salvador de Chora, o en la Mezquita de Kariye en 
Estambul, del siglo XIV, se utiliza la perspectiva invertida con el punto de fuga situado en la posición del observador [21].

El cubismo, desarrollado en la primera década del siglo XX (1907) y considerado como la primera vanguardia, y encabezado, entre otros, por Pablo R uiz Picasso (1881-1973) o Georges Braque (1882-1963), destruye el último de los estatutos renacentistas todavía vigentes a principios del siglo XX: la perspectiva. En la pintura cubista desaparece la idea de perspectiva tradicional e incorpora la definida 'perspectiva múltiple' - con múltiples puntos de vista - donde se representan todas las partes de un objeto en un mismo plano, incorporando, de algún modo, la idea de tiempo. De ese modo, aparecían al mismo tiempo y en el mismo plano, diferentes vistas de un mismo objeto: de frente, de perfil, en planta. En el cubismo se reinterpretan las formas de la naturaleza por medio de figuras geométricas, de algún modo, fragmentando líneas y superficies. EI cubismo surge, entre otros motivos, por la aparición de la fotografía, ya que la pintura se liberaba de la obligación de representar la realidad de una manera exacta.

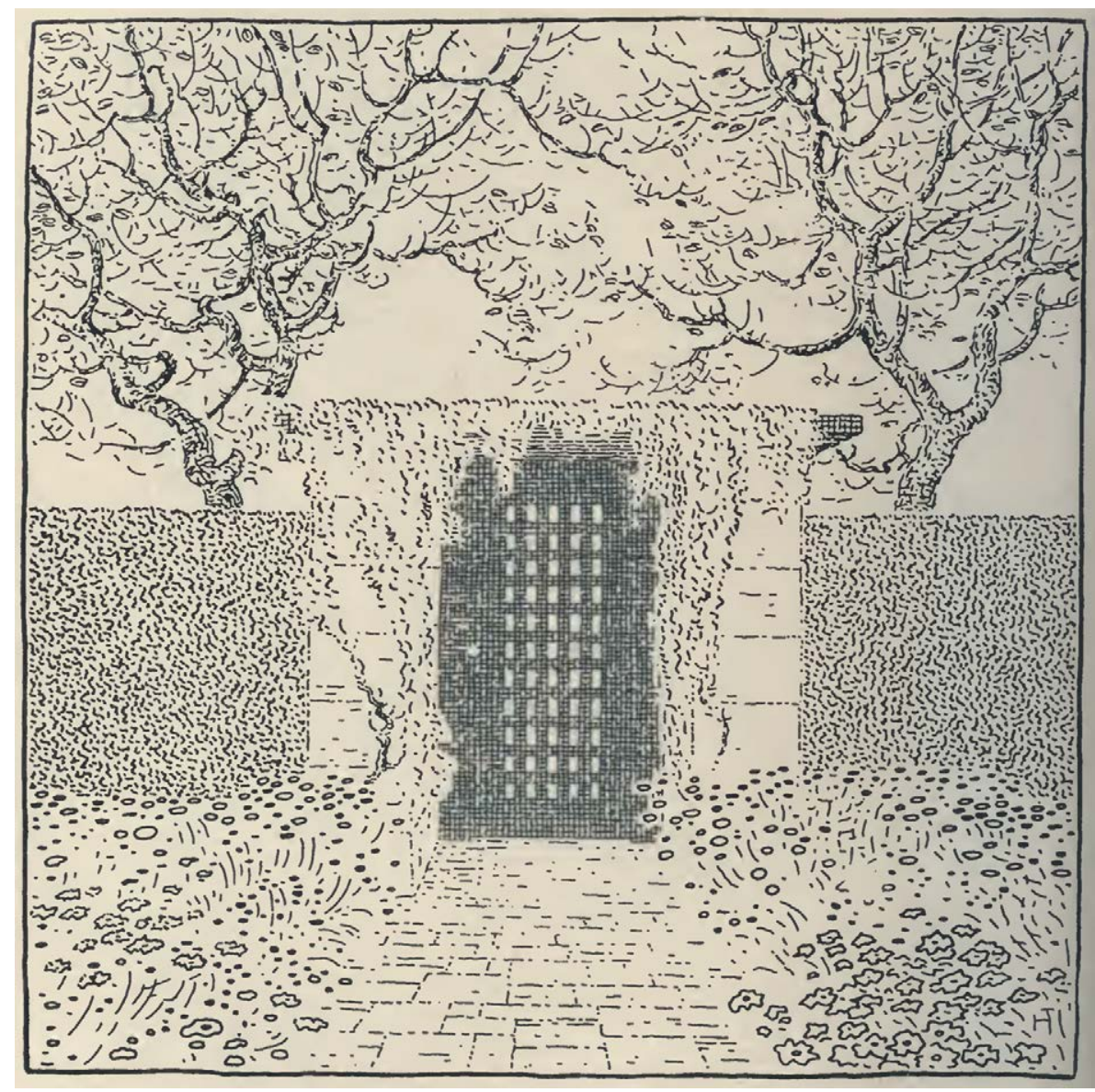

Figura 17.

Perspectiva exterior extraida del libro Hausbau Und Dergleichen (1916). Henri Tessenow. [Fuente: CUniversity of Toronto]
[19] Catálogo de la Exposición The Architecture of the Interior. Delft: Faculty of Architecture and the Built Environment, 2018.

[20] Borchers-Fernández, J uan. Metaarquitectura. Santiago de Chile: Ed. Mathesis, 1975.

[21] Palacios-Díaz, Dolores. «Cuerpo, distancias y arquitectura. La percepción del espacio a través de los sentidos». Directores: Antonio Miranda-Regojo y Nicolás-Maruri González de Mendoza. Madrid: Universidad Politécnica de Madrid, Escuela Técnica Superior de Arquitectura, Departamento de Proyectos Arquitectónicos, 2014. 


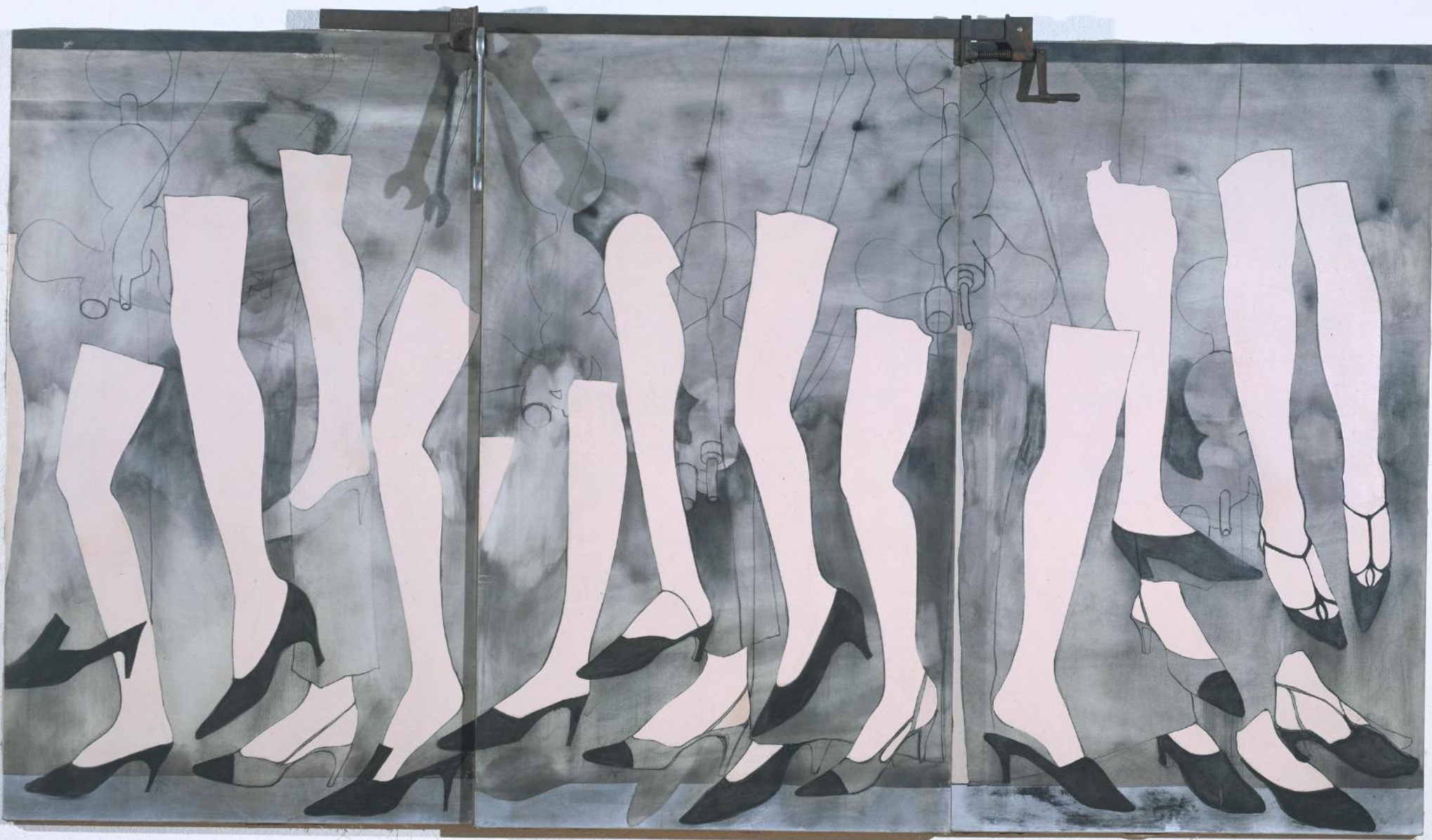




\section{CAPÍTULO 4}

\section{Pie fenomenológico El ojo a ras del suelo Erotismo háptico}

\section{Introducción}

Existe un discurso fenomenológico vinculado al suelo y al pavimento donde la textura, la materialidad, la rugosidad, la temperatura, la topografía (el relieve), el sonido o su comportamiento ante la luz lo asocian generosamente a lo sensual, haciendo que el ojo pierda el monopolio de la emoción delegando en el tacto, el oído y el olfato.

Cuando los pre-homínidos todavía se desplazaban a cuatro patas, el olfato era el sentido más agudo, además del tacto, debido, en parte, a la cercanía de la nariz con el plano del suelo y a que las cuatro extremidades tocaban la tierra. Ya los homínidos, que caminaban erguidos, perfeccionaron la vista al descubrir el horizonte desde una posición más elevada. También el oído y el tacto, al disponer sólo de dos extremidades sobre el suelo. $Y$ en ese momento el gusto y el olfato perdieron intensidad. Desde entonces, el predominio de lo visual ha evolucionado hasta hoy [1].

Juhani Pallasma (1936-), en el artículo «Hapticidad y tiempo, notas acerca de la arquitectura frágil» [2] se lamenta de que la prevalencia de la vista sobre los otros sentidos, ha depositado en las imágenes instantáneas de la arquitectura contemporánea el único modo de seducir [3]:

"La arquitectura proyecta formas para la retina con la finalidad de persuadir de forma inmediata: la planeidad de materiales y superficies, la luz uniforme, la eliminación de las diferencias climáticas, refuerzan la uniformidad actual. La tendencia de la tecnología a normalizar las condiciones del entorno para convertirlo en algo totalmente predecible está ocasio-
Figura 0. Página anterior Walking Dream with Four Foot Clamp (1965). Jin Dine. [Fuente: @TATE, Londres. T00791]
[1] Palacios-Díaz, Dolores. «Cuerpo, distancias y arquitectura. La percepción del espacio a través de los sentidos». Directores: Antonio Miranda-Regojo y Nicolás-Maruri González de Mendoza. Madrid: Universidad Politécnica de Madrid, Escuela Técnica Superior de Arquitectura, Departamento de Proyectos Arquitectónicos, 2014.

[2] Pallasma, J uhani. «Hapticidad y tiempo. Notas acerca de la arquitectura frágil». Pasajes de arquitectura y crítica. Madrid: Reverse Arquitectura, núm. 30, 2001, p. 34.

[3] Palacios-Díaz, Dolores. Op. Cit. 


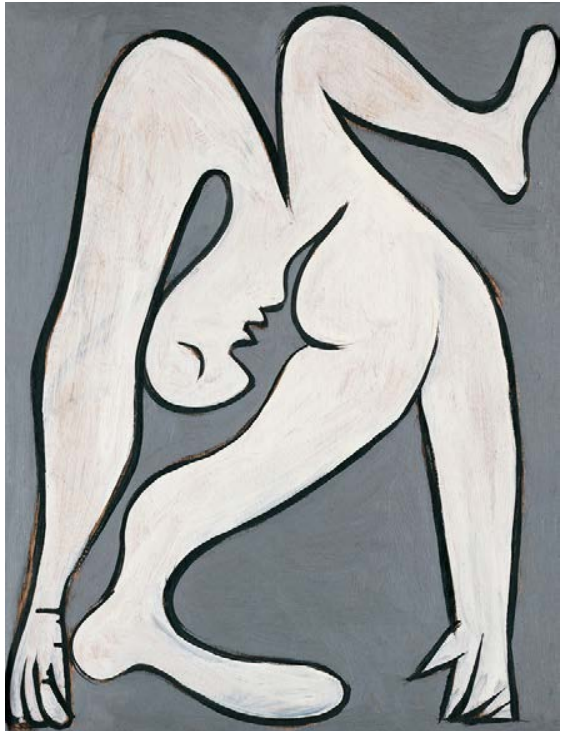

Figura 1.

Acrobat woman / Mujer

Acróbata (1930). Pablo

Picasso. [Fuente: @Museo

Pablo Picasso de Málaga,

VEGAP, Madrid. Fundación

Almine y Bernard Ruiz-Picasso] nando un gran empobrecimiento sensorial. Los edificios han perdido su opacidad y profundidad, la capacidad de invitación y descubrimiento a través de los sentidos, el misterio y la sombra» [4].

Y expresa su defensa por el sentido del tacto:

"Con el título 'Los ojos de la piel' quería expresar la importancia del sentido del tacto para nuestra experiencia y nuestra comprensión del mundo [...] también crear una especie de cortocircuito [...] He aprendido que nuestra piel en realidad es capaz de distinguir una serie de colores: es más, vemos a través de la piel» [5].

Aristóteles (384 a.C.-322 a.C.), en su obra De Anima, advierte, muchos años antes, de la importancia del sentido del tacto:

«Todos los demás sentidos, como por ejemplo el olfato, la vista y el oído, captan las sensaciones utilizando algún medio; pero allí donde se produce un contacto inmediato, la ausencia de sensaciones haría al animal incapaz de tomar unas cosas y dejar otras, con lo que su supervivencia sería imposible [...] Sin el tacto no puede existir ningún otro sentido» [6].

El sentido del tacto recibe, al menos, cinco sensaciones: la presión, el calor, el frío, el dolor y la cinestesia o la sensibilidad al movimiento. $Y$ es que por la piel se puede leer la textura, el peso, la densidad o la temperatura de la materia del suelo. Poder tocar un material nos ofrece más información que la engañosa mirada [7]. «La piel es tanto un receptor de distancia como de inmediación» [8]. La percepción del pavimento no se produce estrictamente mediante el intercambio de energía en la piel de la planta del pie. También la piel del cuerpo percibe el frescor de un pavimento de piedra.

Tal vez el suelo pavimentado, debido a la gran extensión de su superficie, sea de los pocos elementos donde todavía habita la aspereza, la imperfección y lo artesanal. Es decir: el suelo participa en abrir el abanico del placer para que los sentidos disfruten de la experiencia espacial.

Pablo Ruiz Picasso (1881-1973) durante el invierno de 1929, volvió al tema de los acróbatas ya experimentado en su época rosa, realizando seis variaciones sobre el asunto, como por ejemplo Mujer acróbata (1930) (fig. 1). La figura, en su caprichosa disposición, casi imposible, presenta a una mujer con el tronco contorsionado y con sus dos brazos en contacto con el suelo, además de una de sus piernas. Unos párrafos más arriba, ha quedado clara la sensibilidad auditiva que se asocia a los pies del bailarín. Pero quizá sea el acróbata, con su abuso de la subversión, el oficio que requiere que las manos estén permanentemente en contacto con el suelo.

«Me gusta cuando veo en televisión una prueba de atletismo dibujar las figuras humanas en movimiento. Para ello no miro el papel en el que dibujo, fijo la mirada en el televisor y la mano sobre el papel e intento que cada movimiento de la mano coincida con el desplazamiento de la figura que queda registrada como un pantógrafo en el dibujo. No hay tiempo de mirar y dibujar, son acciones simultáneas. El movimiento de la mano y la imaginación son únicos. El dibujo de Picasso es excepcional, va aún más lejos, tiene todo en la cabeza, fruto del intenso estudio de la anatomía y del retrato al natural realizado durante la infancia. ¿Recuerdas las figuras de la serie de la tauromaquia o los faunos, con las patas de los caballos, 

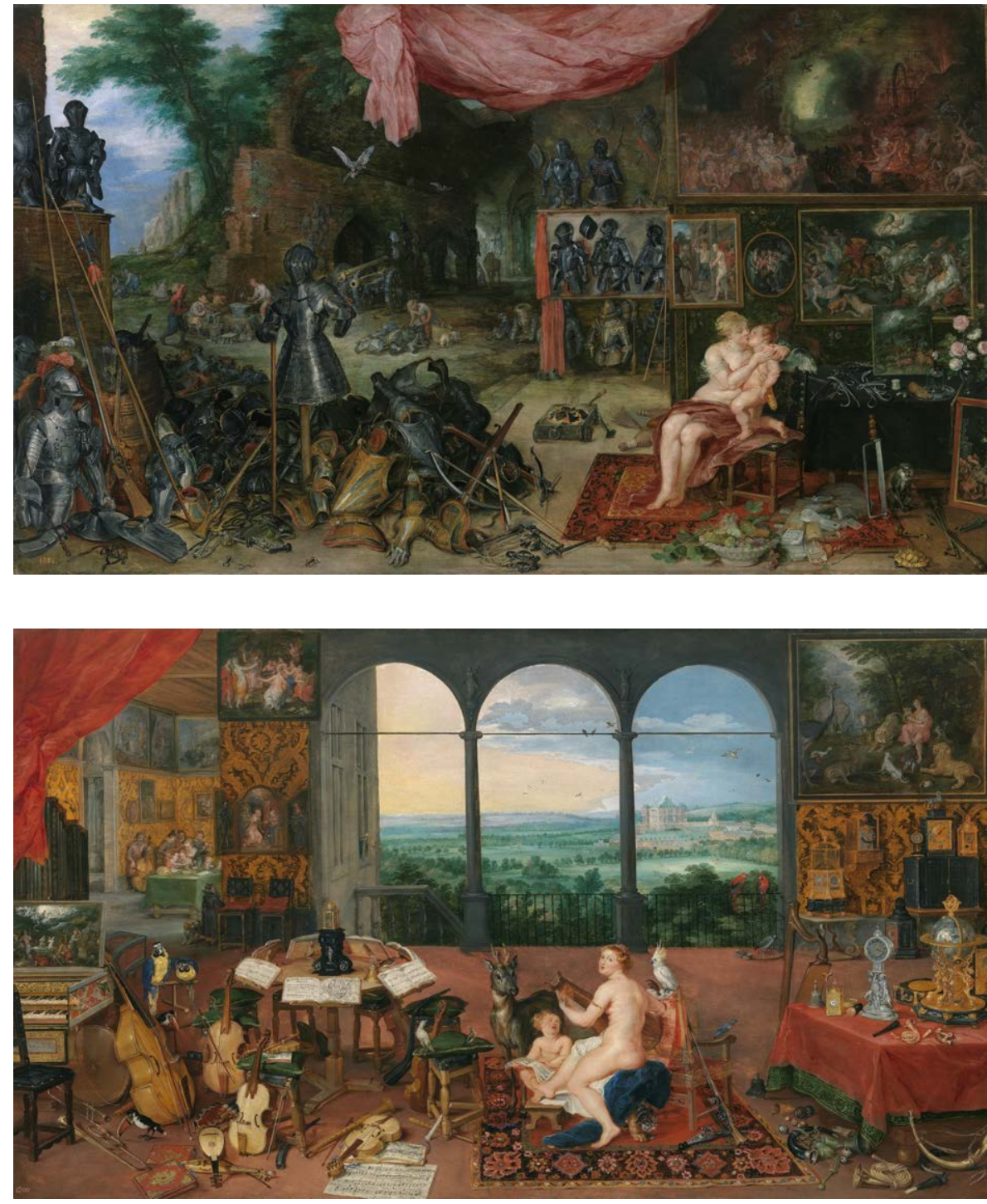

la forma de las manos, la anatomía de las figuras...? Hay muchos años de estudio para llegar a hacer estas líneas así de sueltas y naturales, tan expresivas, sin necesidad de recurrir al modelo. Todo está en su cabeza, en la mente, cada detalle, cada movimiento, cada músculo, sólo tiene que trasladarlo al papel. Ya ni tan siquiera es necesario miran $[9]$.

Jan Brueghel El Viejo (1568-1625) y Pedro Pablo Rubens (1577-1640) colaboran juntos en una alegoría a «Los cinco sentidos»: El Oído (1617-1618), El Gusto (1618), La Vista (1617), El Olfato (1617-1618) y El Tacto (1618). En cada caso se representa, con diferentes elementos, cada uno de los sentidos. Los autores se aprovechan tanto del ámbito donde se representa cada escena de la pintura, de los elementos que aparecen en ella, así como de los personajes. Pero es en El Tacto y en El Oído (fig. 3 y fig. 4) donde los personajes principales - Venus y Cupido- aparecen representados sobre una alfombra. En el caso de Venus, con sus pies desnudos apoyados directamente sobre ese pavimento textil efímero. Es decir, los autores se ayudan de la alfombra y de los pies para expresar con más nitidez la fuerza de estos dos sentidos. Y es que en el suelo pavimentado se produce una experiencia táctil y sonora.

Unos años antes, el teólogo Tommaso d'Aquino, Santo Tomás de Aquino (c1224-1274) en Summa Theologiae (1265-1274) también establecía una dife-
Figura 2.

El Tacto (1618). Juan Brueghel El Viejo y Pedro Pablo Rubens. [Fuente: (OMuseo Nacional del Prado de Madrid. P01398]

Figura 3.

El Oído (1617-1618). Juan Brueghel EI Viejo y Pedro Pablo Rubens. [Fuente: CMuseo Nacional del Prado de Madrid. P01395]
Homage to Magritte Clive Barker. [Fuente: @TATE, Londres. P01803]

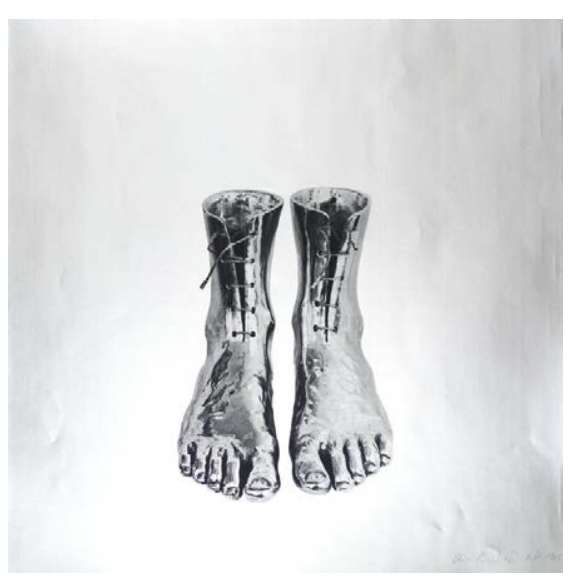



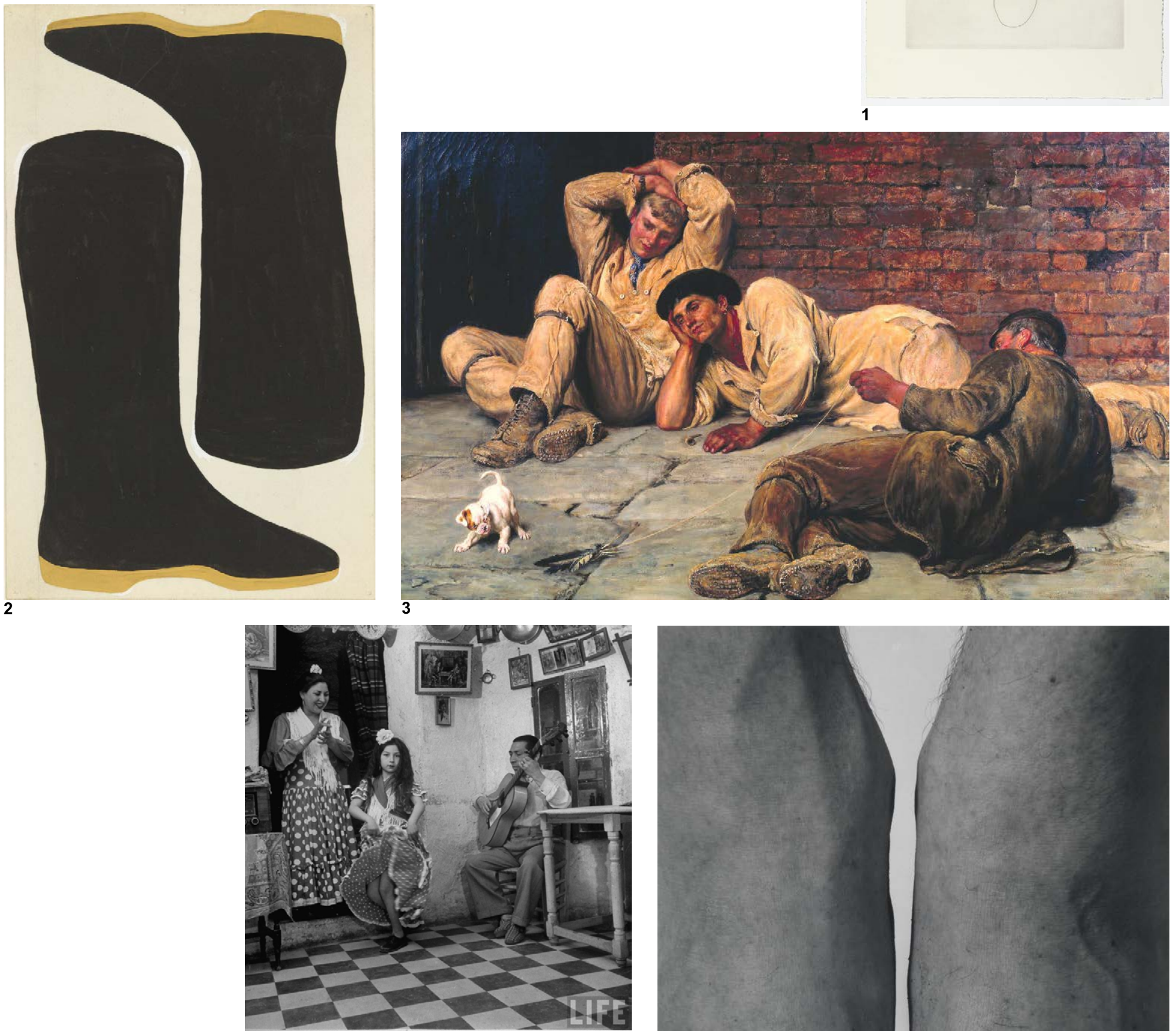

4

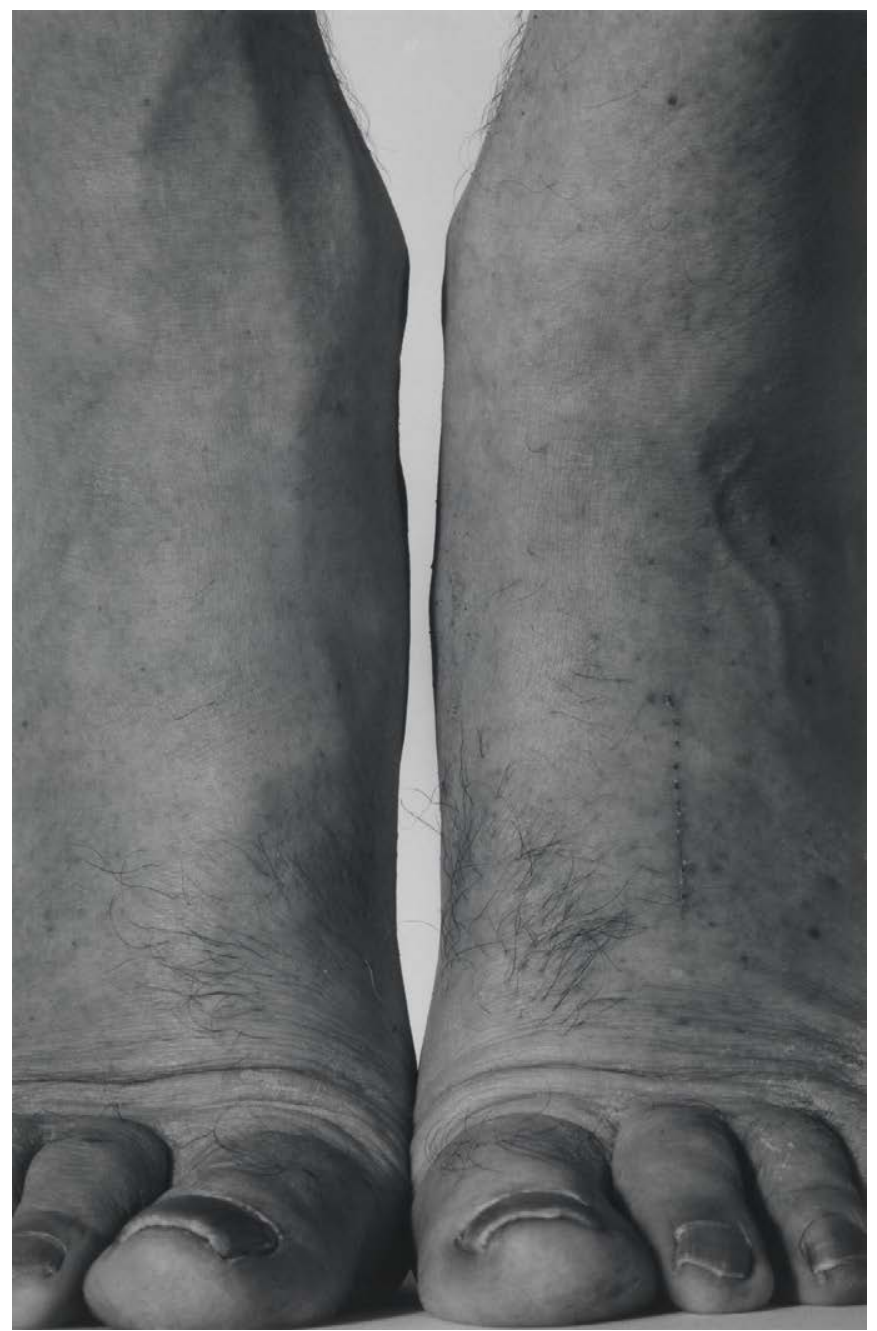

1. Foot with face (1999). Louise BourgeoisAlvar Aalto. [Fuente: CMoMA Museo de Arte Moderno de New York. 528.1997]

2. Bootless Boots (1960). Jo Baer. [Fuente:

CMoMA. Museo de Arte Moderno de New York.

(CThe Judith Rothschild Foundation. Contemporany

Drawings Collection Gift. 1206.2005.a-b]

3. Giants at Play (1882). Briton Riviere. [Fuente:

CTATE, Londres. N01516]

4. Niña flamenca de ocho años bailando en Grana-

da (España) (1949). [Fotografía: @Dmitri Kessel

CLIFE]

5. Self-portrait (Feet Frontal) (1984). John Coplans.

[Fotografía: @John Coplans @TATE, Londres.

P11670] 

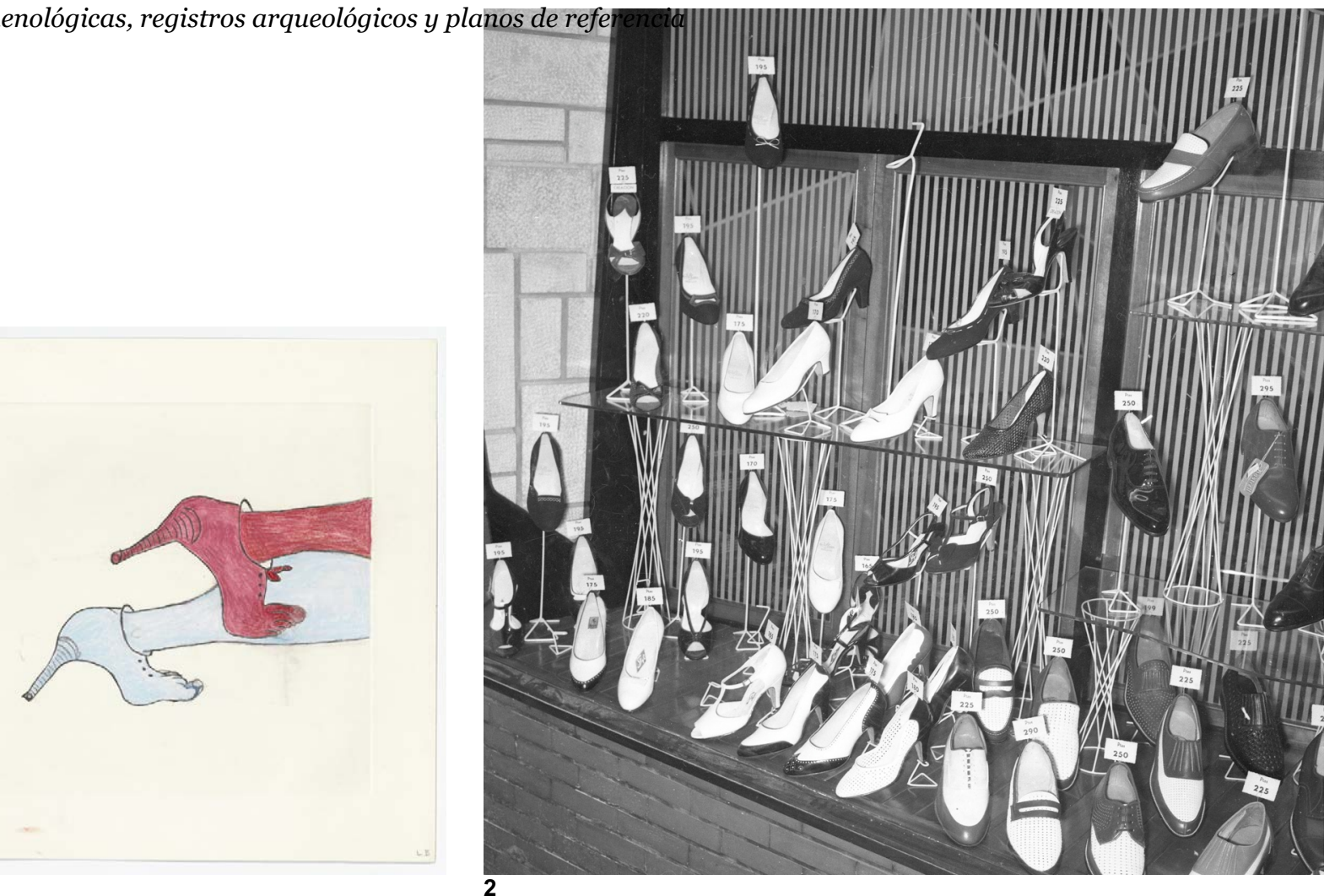

1

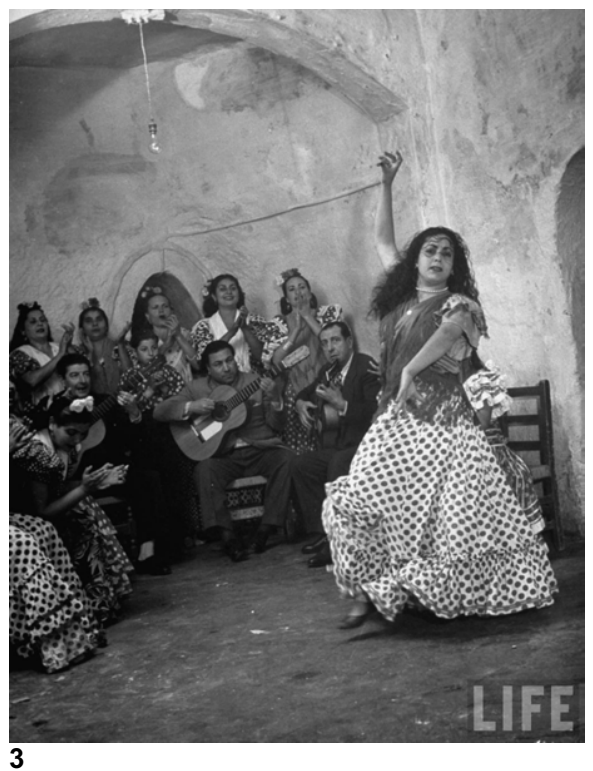

2

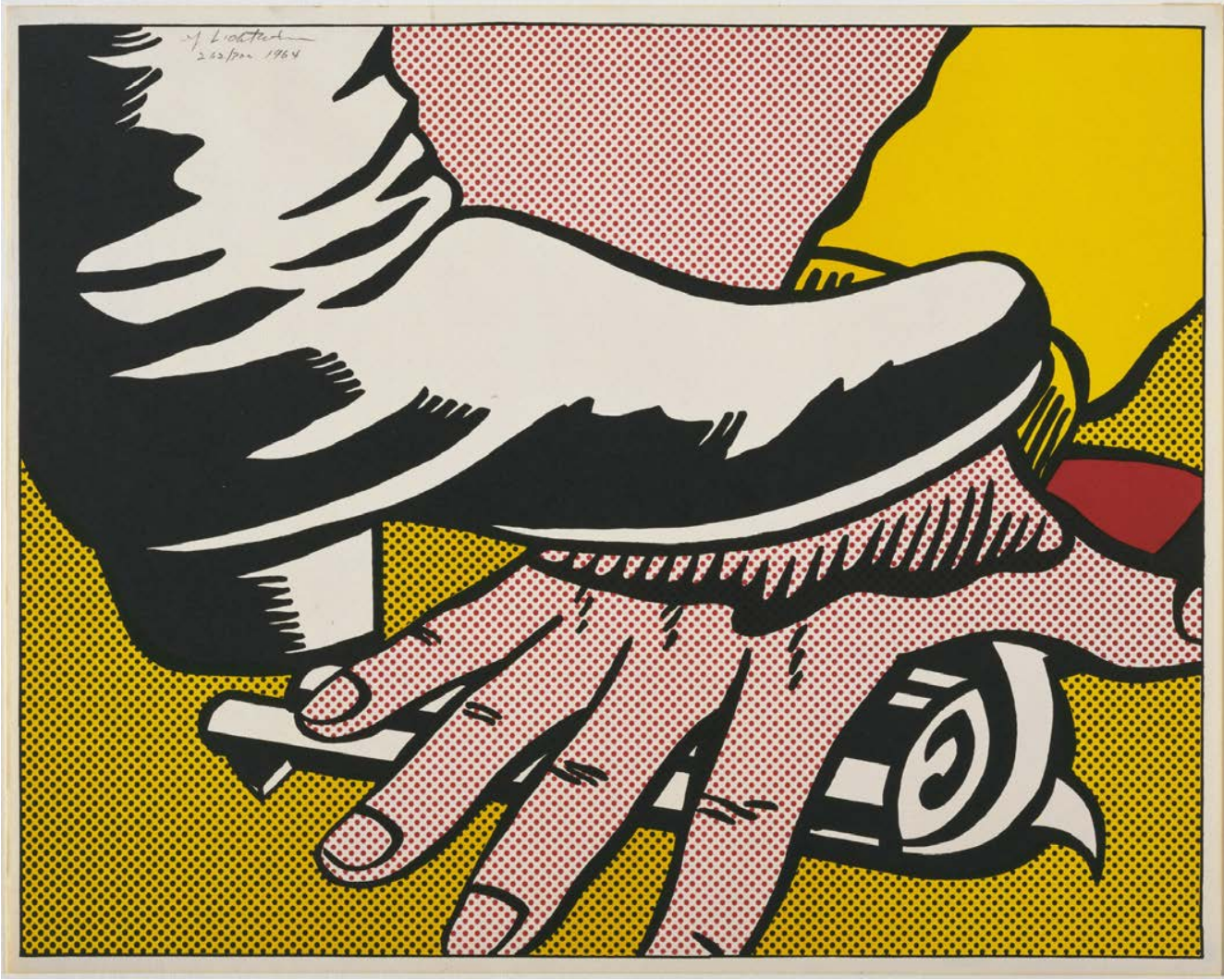

1. Untitled, plate 4 of 7, from the portfolio, Metamorfosis (1999). Louise Bourgeois. [Fuente:

CMoMA. Museo de Arte Moderno de New York]

CThe Easton Foundation/Licensed by VAGA, New York. 22.2002.B4]

2. Escaparate. Zapatería Plaza, Almería (1955).

Fernando Cassinello. [Fuente: @Archivo de la familia Cassinello. CN.01.018]

3. Bailaora flamenca bailando en Granada (España) (1949). [Fotografía: CDmitri Kessel CLIFE] 4. Foot and hand (1964). Roy lichtenstein. [Fuente: MoMA. Museo de Arte Moderno de New York. Gift of Leo and Jean-Chistophe Castelli in memory of Toiny castelli. 359.1988] 

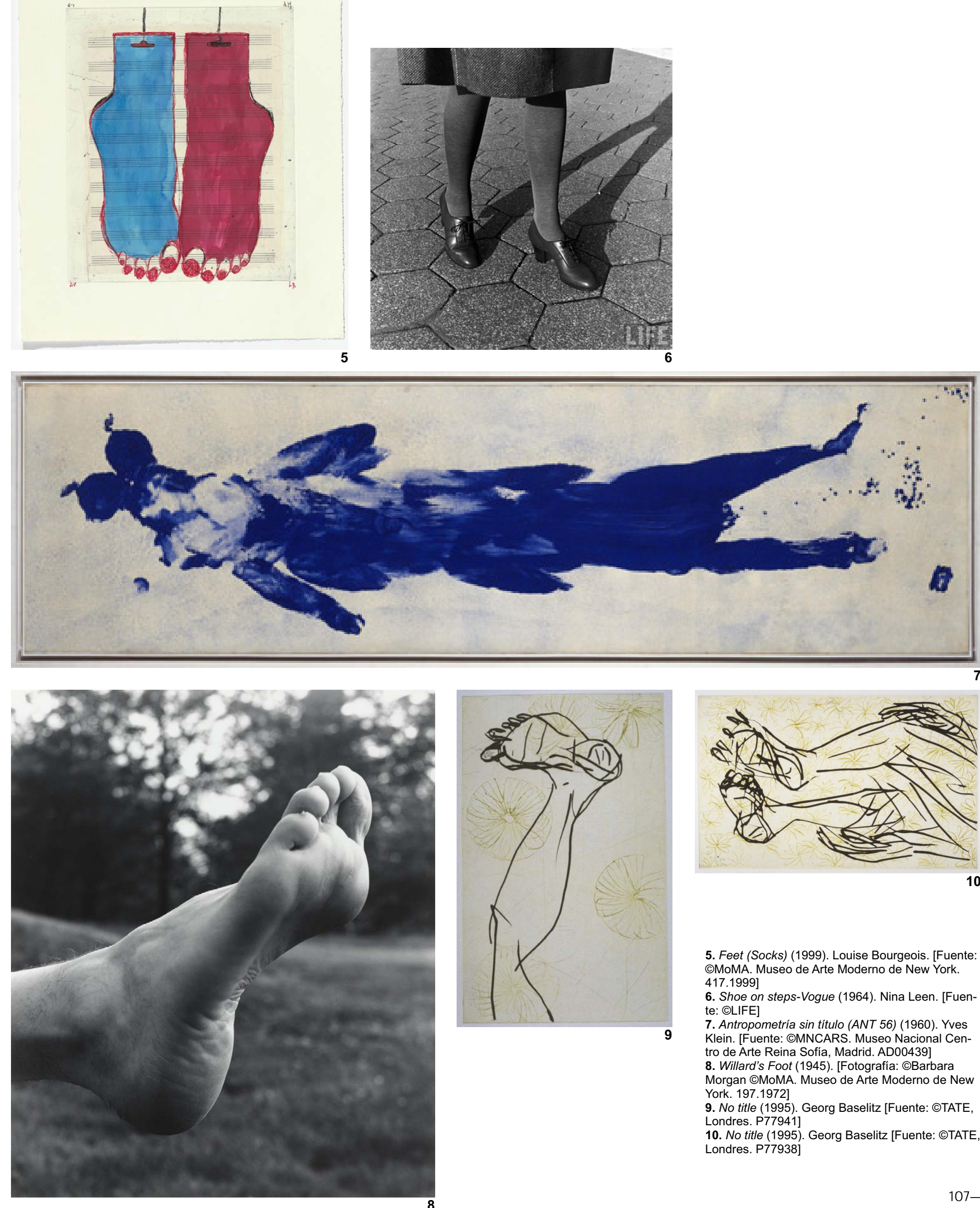

5. Feet (Socks) (1999). Louise Bourgeois. [Fuente: OMoMA. Museo de Arte Moderno de New York. 417.1999]

6. Shoe on steps-Vogue (1964). Nina Leen. [Fuente: CLIFE]

7. Antropometría sin título (ANT 56) (1960). Yves Klein. [Fuente: $O M N C A R S$. Museo Nacional Centro de Arte Reina Sofía, Madrid. AD00439] 8. Willard's Foot (1945). [Fotografía: @Barbara Morgan $\odot$ MoMA. Museo de Arte Moderno de New York. 197.1972]

9. No title (1995). Georg Baselitz [Fuente: OTATE, 9. No title (1995).

10. No title (1995). Georg Baselitz [Fuente: OTATE, Londres. P77938] 


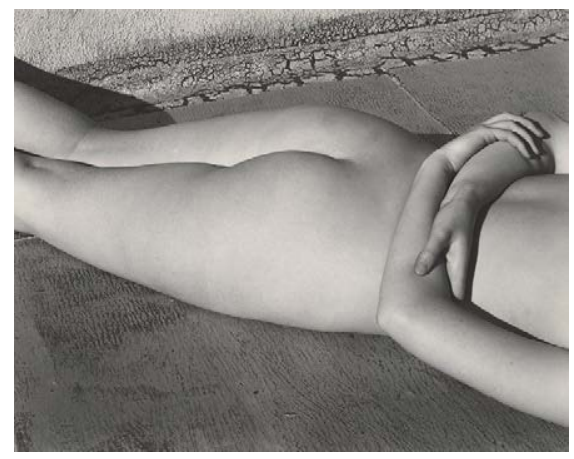

Figura 5

Desnudo / Nude (1936).

[Fotografía: @Edward Weston

(C) Center for Creative

Photography]

Figura 6.

México (1934). [Fotografía:

(C)Henri Cartier-Bresson CMagnum Photos. PAR17866]

[10] Palacios-Díaz, Dolores. «Cuerpo, distancias y arquitectura. La percepción del espacio a través de los sentidos». Directores: Antonio Miranda-Regojo y Nicolás-Maruri González de Mendoza. Madrid:

Universidad Politécnica de Madrid, Escuela Técnica Superior de Arquitectura, Departamento de Proyectos Arquitectónicos, 2014.

[11] Koolhaas, Rem (ed.) y Easterling, Keller. «Floor». En: Elements of architecture. The Venice Biennale. 14th International Architecture Exhibition. Venezia: Marsilio Editori, 2014.

[12] Fantoni, Marco. «Los cinco sentidos de Norman Foster». En: Norman Foster. Proyectos 1988 [catálogo de la exposición]. Madrid: Dirección General para la Vivienda y Arquitectura, MOPU, 1988. p. 25.

[13] Bocco-Guarneri, Andrea. «Un catálogo de posibilidades. Un viaje por las ideas rudofskianas sobre la Lebensweise». En: Loren-Méndez, Mar y Romero-Gómez, Yolanda (Ed.). Bernard Rudofsky. Desobediencia crítica a la modernidad. Granada: Centro J osé Guerrero y Diputación de Granada, 2014. p. 96 .

[14] Rudofsky, Bernard. «Non ci vuole un nuovo modo di costruire, ci vuole un nuevo modo di vivere (commento al disegno di una casa all'isola di Procida) / We don't need a new way to build. Design proposal for a courtyard villa on Procida island, Italy». Domus. Italy: Editoriale Domus, march 1938, núm. 123, pp. 6-15.

[15] Lafuente-Sánchez, Víctor. «Gio Ponti y Bernard Rudofsky: la casa mediterránea y su representación en la revista Domus / Gio Ponti and Bernard Rudofsky: The mediterranean house and its repre sentation in the journal Domus».. EGA. Expresión Gráfica Arquitectónica. Valencia: Universitat Politècnica de València, 2015, núm. 26, pp. 256265. [https:// doi.org/ 10.4995/ ega.2015.4059] (02/02/2019)

[16] Rudofsky, Bernard. The prodigious builders: notes toward a natural history of architecture with special regard to those species that are traditionally neglected or downright ignored. Nueva York: Harcourt Brace J ovanovich, 1977. p. 107.

[17] Rudofsky, Bernard. Streets for people. A primer for americans. Garden City, Nueva York: Doubleday \& Co., 1969. p. 266.

[18] Ibíd.

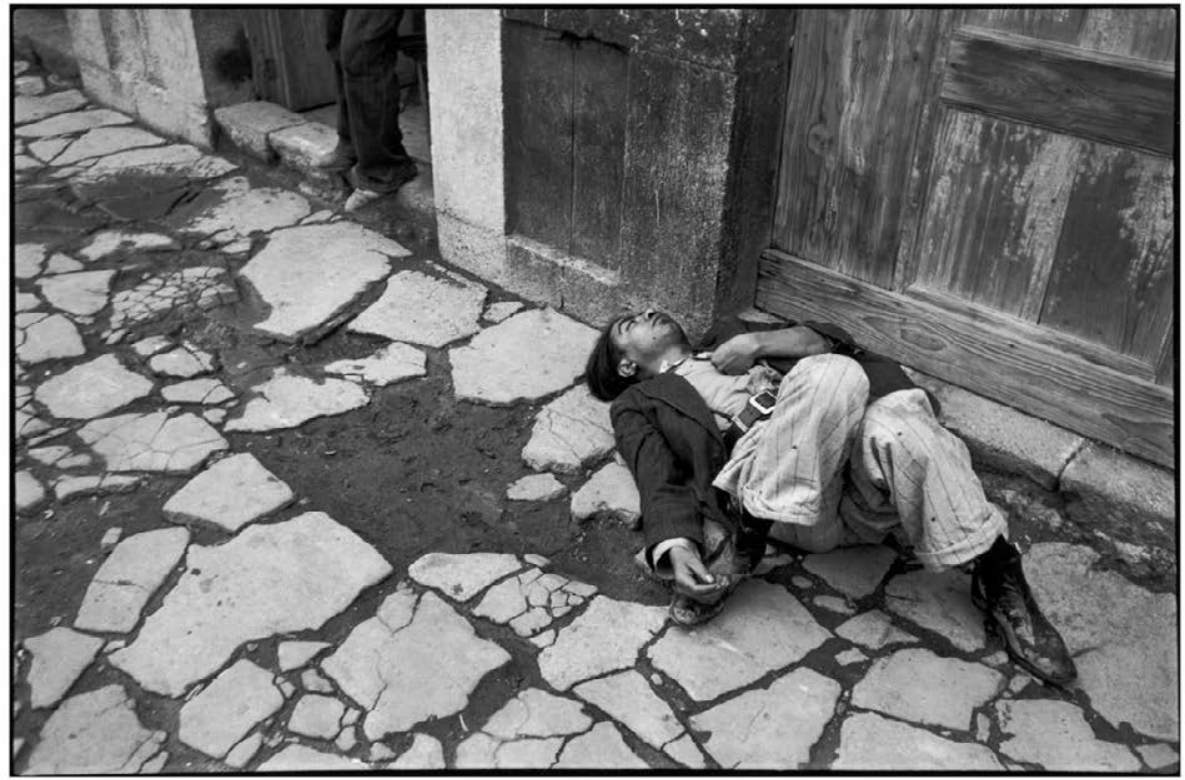

rencia entre la vista y el resto de los sentidos. Incluso se atrevía a proponer una clasificación jerárquica de los sentidos desde un punto de vista moral. Y que más o menos quedaba establecida así: el gusto, el olfato y el tacto los relacionaba con la gula y la lujuria o la vista se vinculaba con la envidia. Para Santo Tomás, el tacto se actualiza mediante lo palpable, y era jerárquicamente primero en la sistematización de las potencias perceptivas. Explica que hay animales que no tienen capacidad visual, pero sería imposible que no tuvieran el sentido del tacto. Si bien para él la limitación del tacto estaba relacionada con la inmediatez del objeto. Tal vez, estaba pensando en la experiencia táctil de las manos, y es que los pies, irremediablemente, están permanentemente en contacto con el suelo.

En 1921, Filippo Tommaso Marinetti (1876-1944) propone la recuperación del sentido del tacto con el «Manifiesto del Tactilismo». En él plantea elaborar objetos para tocar, pero con el deseo de reconstruir el entorno. Así se plantean paneles de diferentes escalas donde se adhieren elementos de diversas texturas. En uno de ellos, Marinetti coloca en un lado texturas rugosas, arenosas y áridas, que evocan los paisajes de Sudán; en otro lado del panel coloca valores táctiles sedosos, suaves y delicados que recuerdan la ciudad de París. Esto deriva a la instalación de «habitaciones táctiles» donde los usuarios podían experimentar con sensaciones hápticas fruto del contacto con el cristal, la roca, los metales, las telas, el mármol o el terciopelo [10].

El suelo pavimentado es un campo horizontal responsable de la sensualidad por contacto, ya que en todo momento está rozando o comunicándose con el cuerpo de forma íntima, a veces con el pie, a veces con las manos, a veces con la cabeza, a veces con el talle. El suelo participa en la orientación y en el movimiento. El pavimento tiene la posibilidad de organizar el tránsito mediante patrones gráficos, pero también es capaz de ofrecer información simplemente con una leve modificación del relieve —-bien sea una protuberancia, bien sea una depresión [11]—o un cambio de textura.

Por tanto, existen dos tipos de arquitectos: los cerebrales y los corporales. Los primeros encuentran en el pensamiento abstracto la esencia de la creación, y éste se puede resumir en una palabra o un dibujo. Los segundos imploran un contacto físico y aspiran a satisfacer a todos los sentidos [12]. 
Para Bernard Rudofsky (1905-1988) (fig. 7) —arquitecto, crítico, fotógrafo, comisario, artista plástico, dibujante o profesor universitario-, que claramente pertenecía al segundo grupo, el pavimento era la parte más importante de un edificio. Lo vinculaba definitivamente a lo sensorial y al disfrute del hombre al caminarlos. Para él, debía tener cualidades eróticas ya que consideraba que la piel era el órgano erógeno por excelencia [13]. «Durante mucho tiempo hemos perdido el contacto con el suelo» [14]: con esta rotunda afirmación, Bernard Rudofsky introduce un artículo publicado en la revista Domus en marzo de 1938 sobre la casa en la Isla de Procida con el sugerente título: «No necesitamos una nueva forma de construir, sino una nueva forma de vivir». Para él, la arquitectura era un «espejo de la sociedad». Así, teorizando en torno al proceso creativo y de diseño, se remontaba al modo de vida de los antiguos romanos hasta llegar a la casa mediterránea y a los modos de vida tradicionales [15].

Le interesaban los pavimentos escultóricos, es decir, los no necesariamente planos: aquellos que se pudieran disfrutar caminando descalzo. Para la exposición Are clothes modern? celebrada en el MoMA de New York (noviembre 1944marzo 1945) construyó un pavimento temporal, con la intención de que los visitantes caminaran descalzos sobre él (fig. 8). No lo consiguió: «en aquel momento andar descalzo tenía aires de exhibicionismo, o algo peor» - se quejaba unos años después [16]. Para él no sólo era importante si los pavimentos estaban alabeados, sino también la materialidad de los suelos interiores y exteriores. Y, desde luego, la pavimentación de las calles y plazas ya que «después de todo, son la extensión de los pavimentos de las casas» [17]. Incluso llegó a proponer el uso del barro como material para pavimentar las calles (fig. 9).

«Los pavimentos en las calles representan la bajamar del ambiente urbano. [...] Nunca se le ha pasado a nadie por la cabeza que un pavimento urbano puede ser adaptado para la gente; es después de todo la extensión del suelo de la vivienda». "En todo momento, y mucho tiempo antes de que se convirtiera en el escenario donde las acciones y emociones de la gente se intercambiaran por dinero, la calle misma ha sido el gran teatro del mundo. El drama y la comedia, tanto espontáneos como artificiales, fueron proporcionados por la vida cotidiana. La calle era el escenario de funerales y bodas» [18].

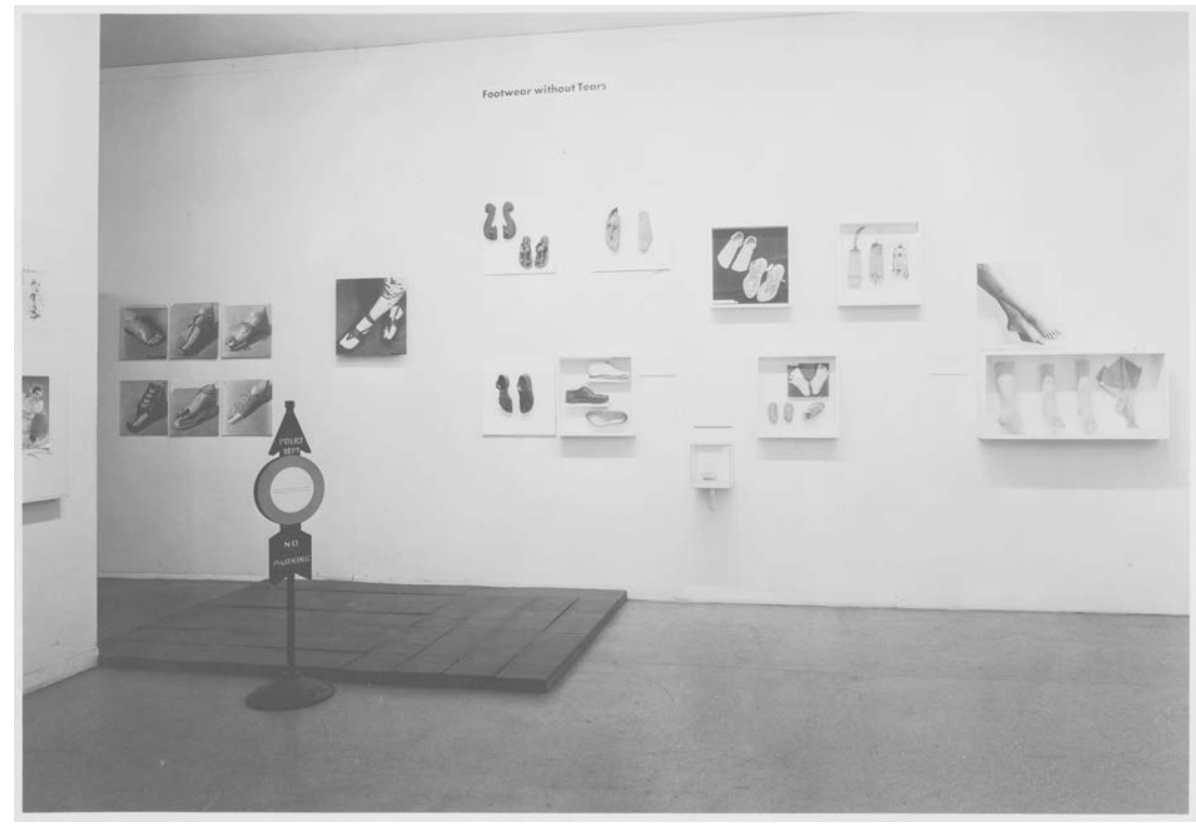

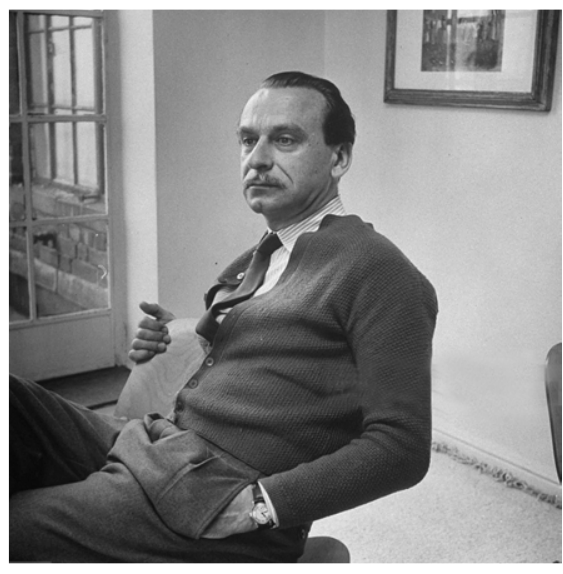

Figura 7.

Retrato de Bernard Rudofsky (1951). [Fotografía: CNina Leen CGetty Images CLIFE. 50868825. 00729347]

Figura 8.

Pavimento efímero instalado por Bernard Rudfosky en la Exposición Are Clothes Modern? celebrada en el MoMA (28 de noviembre de 1944-4 de marzo de 1945). [Fotografía: (Soichi Sunami CMoMA. Museo de Arte Moderno de New York] viandante en la calle Tetuán de Marbella, Málaga (1971). [Fotografía: @Bernard Rudofsky cGetty Images]

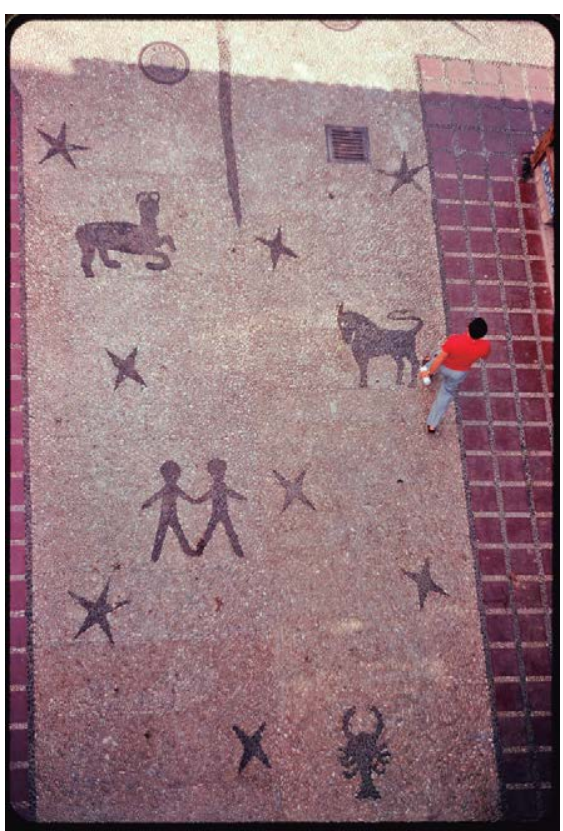




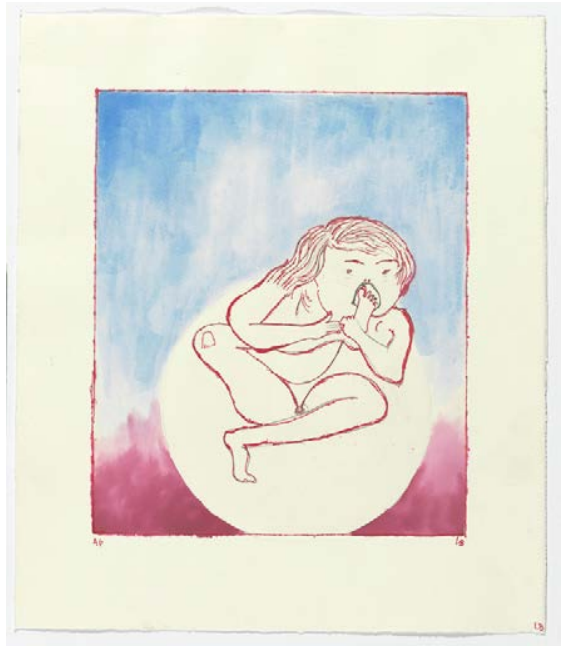

Figura 10.

Don't Put Your Foot in Your

Mouth (1999). Louise

Bourgeois. [Fuente: OMoMA

Museo de Arte Moderno de

New York. 896.2008]
Untitled plate 3 of 7 , from the portfolio Metamorfosis (1999). Louise Bourgeois. [Fuente: CMoMA. Museo de Arte Moderno de New York. CThe Easton Foundation/Licensed by VAGA, New York. 22.2202.B3]

Figura 12

Foot Medication (1963). Roy

Lichtenstein. [Fuente: @MoMA.

Museo de Arte Moderno de

New York. 360.1988]

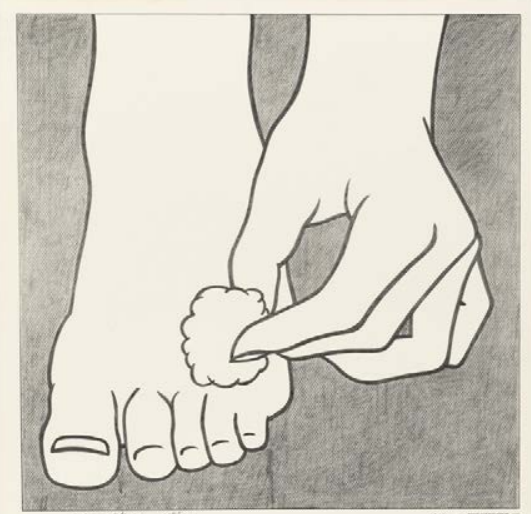

Además, el suelo está etimológica y antropológicamente ligado a la planta del pie. Lo representa bien la artista Louise Bourgeois (1911-2010) en una de las láminas de su obra Metamorfosis (1999) (fig. 11) donde dibuja a dos pies con un ojo en cada planta o en la obra Don't put your foot in your mouth (1999) (fig. 10). Una parte de la investigación de esta artista, se centra en la representación de los pies. También encontramos en el arte de la cultura pop referencias a esta condición sensible del pie como receptor último de impulsos, como en la obra Foot medication (1963) (fig. 12) de Roy Lichtenstein. Pero también en el filósofo Friedrich Nietzsche cuando en su obra maestra escribe: «el bailarín tiene su oído en los dedos de los pies» [19]. Y es que el ojo también tiene la posibilidad de 'tocar' ya que incluso antes de mirar a un objeto ya lo hemos tocado. Como dice Maurice Merleau-Ponty (1908-1961): «a través de la vista tocamos las estrellas y el sol» [20].

La arquitectura es perceptible también para las personas ciegas. Cuando falta uno de los sentidos se produce inmediatamente la estimulación y el desarrollo del resto: el tacto, el oído, el olfato y el gusto. Los ciegos, cuando se desplazan, se sirven sobre todo del tacto y del oído. Incluso los cambios de temperatura, de el color de la superficie y de la luz que puedan absorber son aspectos sensibles para las personas con problemas de visión. Por ello, las superficies continuas lisas son un enemigo para las personas invidentes. Por todo ello, las normativas obligan, sobre todo en los espacios públicos, a proponer pavimentos cuyas texturas y rugosidad faciliten el tránsito y la orientación de todas las personas, también de las ciegas. 
La arquitectura japonesa desarrolló un sistema 'Braille' para los pies — tanto los pies desnudos como los vestidos con calcetines- (fig. 13 y fig. 14) En 1965, el empresario japonés Seiichi Miyake (1926-1982) desarrolla el pavimento táctil (losas Tenji, superficie podotáctil) para personas ciegas, sobre todo, para la circulación en zonas de tráfico — de peatones y de vehículos- El pavimento lo instaló por primera vez en 1967 en una escuela para ciegos en Okayama, su ciudad natal. Las piezas de pavimento que diseñó presentaban dos relieves principales: uno con forma de círculos y otro con forma de barras longitudinales. El primero significaba que el peatón ciego debía de pararse, o al menos prestar atención a la situación. Y el segundo, formado por barras longitudinales, implicaba que el peatón ciego debía seguir precisamente en la dirección que marcaban las barras. Este pavimento se instaló al poco tiempo en la estaciones de tren de Japón y después se extendió por todo el mundo.

\section{Pies y Zapatos}

Los pies, de forma ineludible, son las extremidades que están permanentemente en contacto con el suelo (fig. 18). Nuestra relación táctil con el pavimento se produce, en condiciones normales, con los pies. A través de ellos, de forma predominante, percibimos la textura, la temperatura o la dureza del pavimento.

El pie desnudo ha sido un fetiche para algunos hombres [21] (podofilia, en inglés foot fetish) a lo largo de toda la historia, algo que se ha intensificado durante el siglo XX debido, en parte, a la liberación sexual (fig. 16). El cineasta Luis Buñuel (1900-1983) sentía veneración por los pies. En algunas de sus películas aparecen primeros planos de los tobillos, de los dedos de los pies, de las pantorrillas o de los zapatos de tacón alto. En 'La edad de oro' (1930), la protagonista chupa el dedo gordo del pie de una estatua romana tratando de aliviar así la pérdida de un amor. En 'Viridiana' (1961), el zapato de su difunta esposa despierta el erotismo en don Jaime, quien además también se excita con los pies de su sobrina. Y en 'Diario de una camarera' (1964) el anciano muere abrazado a unos botines [22].

El zapato es un elemento intermediario entre el pie desnudo y el suelo -pavimentado o no. De algún modo, y debido al contacto, se produce un intercambio de energía entre la delicada y sensible piel de la planta del pie y el áspero pavi-

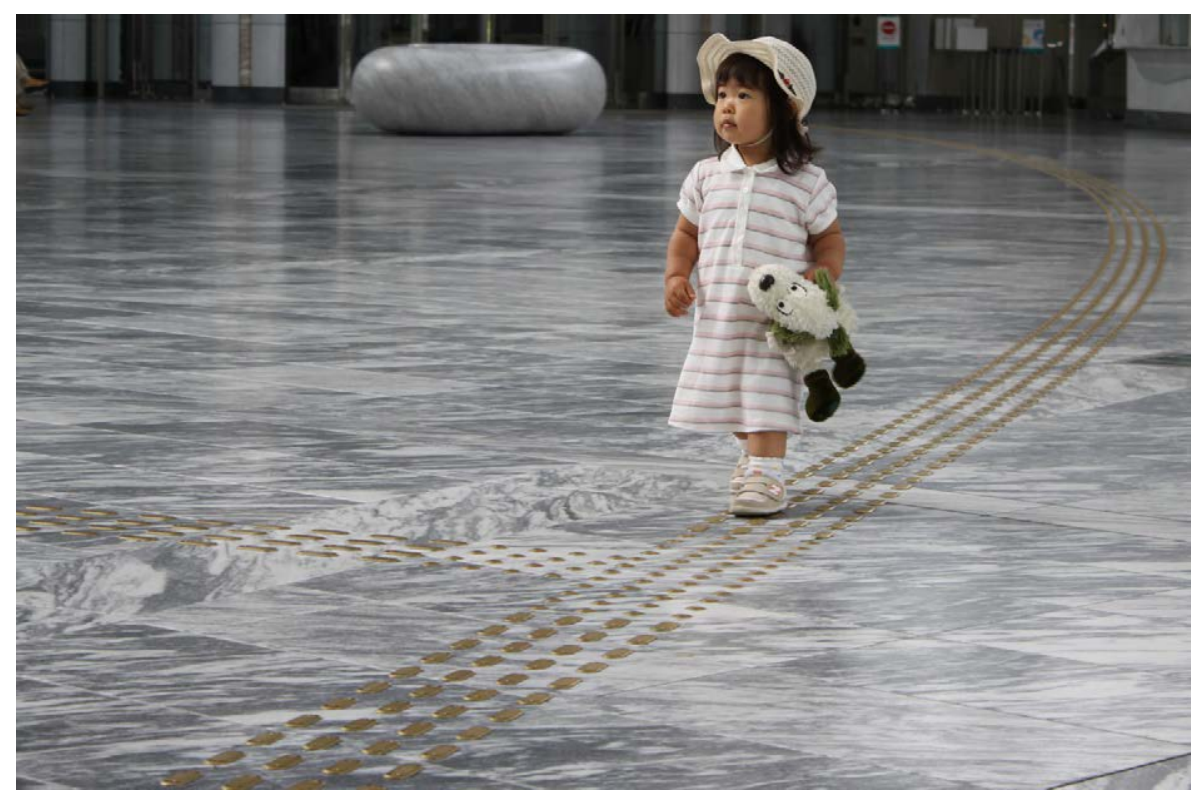

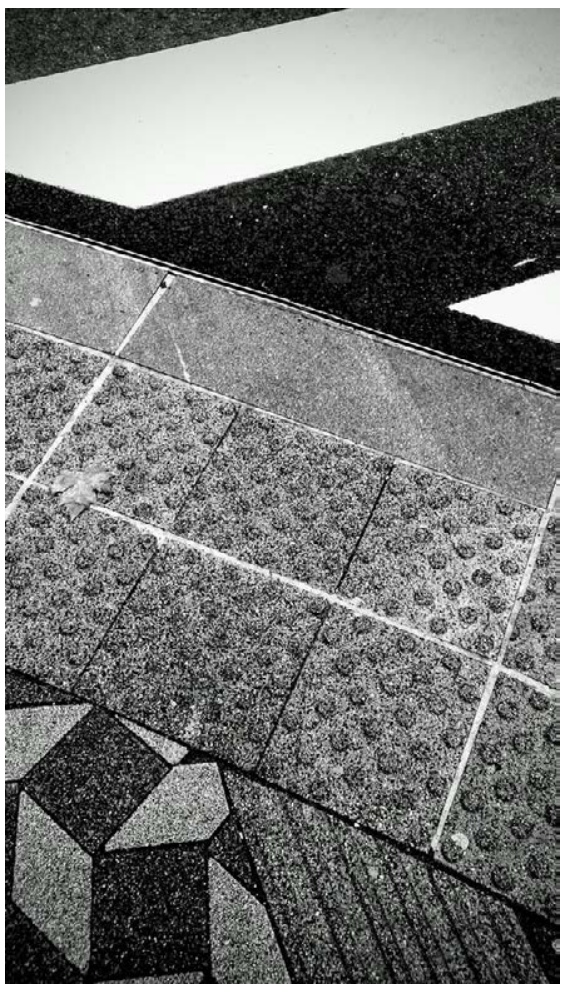

Figura 13

Texturas de pavimentos con relieve para facilitar el tránsito de las personas ciegas (2018) [Fotografia: (C) Cobra]

Figura 14

My daughter. Sakurakko

walking the braille block (2010).

[Fotografía: @Miki Yoshihito]

[19] Nietzsche, Friedrich. Also spracht Zarathustra [1883-1885]. García-Borrón, J uan Carlos (trad.): Así habló Zaratustra. Barcelona: Folio, Colección de obras fundamentales de la filosofía, 2000.

[20] Merleau-Ponty, Maurice. El ojo y el espíritu. Colección Biblioteca del Hombre Contemporáneo, número 40. Buenos Aires: Editorial Paidós, 1977.

[21] El fetichismo del pie en las mujeres es un comportamiento no estudiado.

[22] Benito, Marián. «Fetichismo: cuando el pie es el objeto de deseo». El Mundo. Madrid: Unidad Editorial, 10 de marzo de 2016.

[https:/ / www.elmundo.es/yodona/ 2016/ 03/ 10/ 56 e04490ca4741d40a8b462f.html] (01/01/2019). 


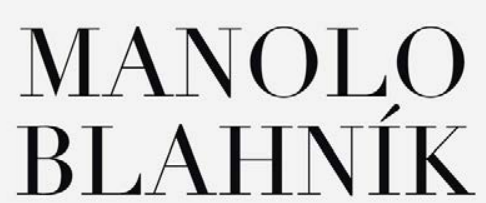

EL ARTE DEL ZAPATO

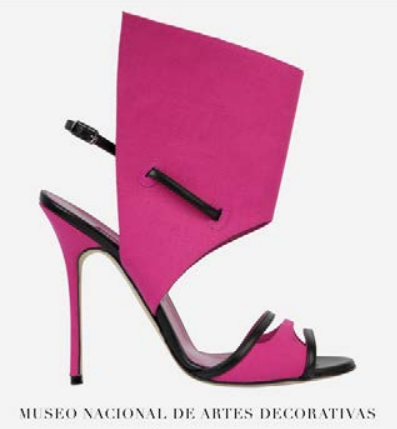

Figura 15.

Cartel de la Exposición 'Manolo

Blahnik: el arte del zapato'

celebrada en el Museo

Nacional de Artes Decorativas

de Madrid (2017). [Fotografía:

@Manolo Blahník @Museo

Nacional de Artes Decorativas

de Madrid]

Figura 16.

Summer Beach Fashions: Pleated skirt and patent-le. Florida (Estados Unidos) (1950). [Fotografía: ONina Leen @LIFE @Getty Images]

[23] Moneo-Vallés, Rafael. En: Carrillo de Albornoz, Cristina (comis.). Exposición: Manolo Blahník, el arte del zapato. Madrid: Museo Nacional de Artes Decorativas, 28 de noviembre de 2017-8 de marzo de 2018. mento del suelo. Existen muchos modelos de zapatos, pero una parte imprescindible de ellos es la suela, es decir, la superficie que sustituye y que protege a la planta del pie del plano hostil en el que a veces se convierte el suelo.

El zapato es el accesorio de la vestimenta encargado de dotar, casi siempre, de confort. Pero también es un elemento que cubre el pie, y sobre el que irremediablemente también se proyecta un fetichismo estético. La moda lo ha incorporado como un objeto de deseo, como un símbolo de representación, incluso como un elemento codiciado de colección. Los humildes artesanos zapateros que resolvían una necesidad básica de servicio, se han convertido en diseñadores reconocidos y con prestigio social. Así, en una Exposición monográfica sobre el diseñador de zapatos Manolo Blahnik (1942-) (fig. 15)aparecía una cita de Rafael Moneo (1937-) junto con una perspectiva - desde el suelo hacia el techo- del Museo Nacional de Arte Romano de Mérida (1986):

«Manolo Blahnik dibuja y realza la compleja arquitectura del pie con ayuda del ornamento, escogiendo con libertad el leitmotiv para él mismo, que desarrolla con la misma naturalidad con la que un músico, una vez elegido el tono, mueve los compases en una partitura» [23].

Tradicionalmente ha existido una relación entre los diseñadores encargados de dar forma a los objetos del ajuar o del atuendo, con la arquitectura. Manolo Blahník (fig. X), por ejemplo, vincula su pasión por las proporciones del pie con sus investigaciones y estudios de las esculturas de los artistas griegos Fidias (500 a.C.-431 a.C) y Praxítele (c400a.C-320 a.C). La necesidad de crear, no sólo un objeto armónico, sino además una construcción sólida, le impulsa a

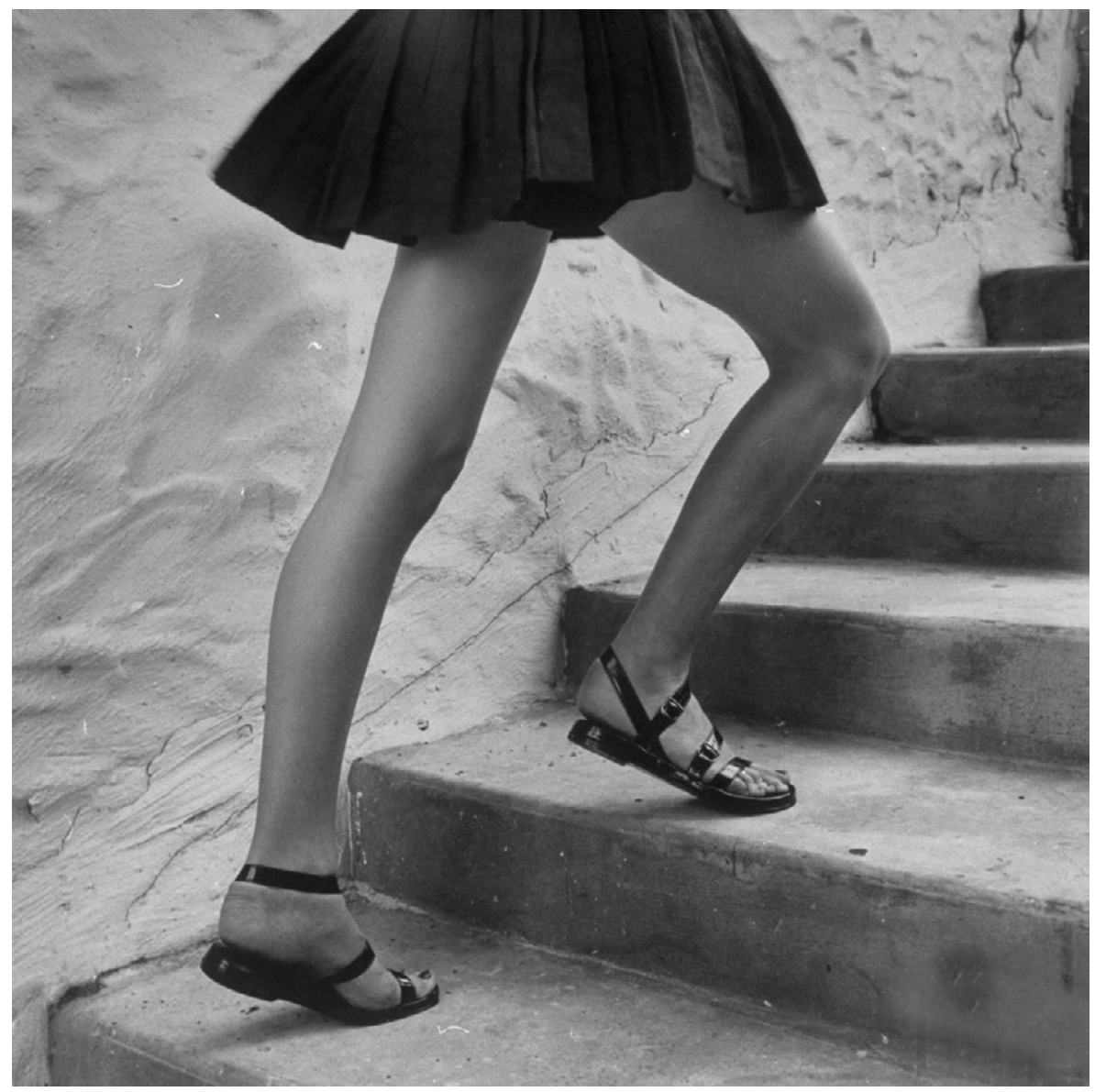


inspirarse en la arquitectura. Entre sus referencias se encuentran la iglesia de Sant'Ivo alla Sapienza en Roma de Francesco Borromini (1599-1667) pero también otras obras de Frank Lloyd Wright (1886-1960) o Walter Gropious (1883-1969).

Andy Warhol (1928-1987) empezó dibujando zapatos cuando trabajaba de joven ilustrador de moda comercial en New York en la década de los 1950. Lo hizo para la firma I. Miller. El periódico New York Times o las revistas Life o Glamour publicaban, regularmente, anuncios o artículos ilustrados con los zapatos dibujados por Warhol. Unos años más tarde, en la década de 1980, retomó el tema. En sus archivos destaca, incluso, un pie momificado. Por tanto, es evidente la fascinación por el pie, por el órgano de transición entre el cuerpo y el suelo. En su obra Á la recherche du shoe perdu (c1950) —un título inspirado en la novela de Marcel Proust: Á la recherche du temps perdu (La búsqueda del tiempo perdido, En busca del tiempo perdido)_ representa un zapato en cada una de las dieciséis láminas, acompañado de una línea de texto - 'Shoe Bright', 'The Autobiography of Alice B' o 'Shoe and Boot'- caligrafiada por la madre de Warhol.

Las pasarelas, las alfombras rojas, en definitiva, los espacios pavimentados donde predomina la dirección longitudinal _incluso los pasillos, las galerías o los claustros porticados - son escenarios donde se representa el teatro social, bien sea como símbolo de vanidad, bien sea como acto de recogimiento y procesión. Warhol decía que en las pasarelas, los modelos caminaban para ser vistos - y lo hacían como si fuera el trote de un caballo o cruzando las piernas, casi sin sonreír-y que tenían la obligación de posar su pies con más seguridad de la que lo hacían en actividades diarias.

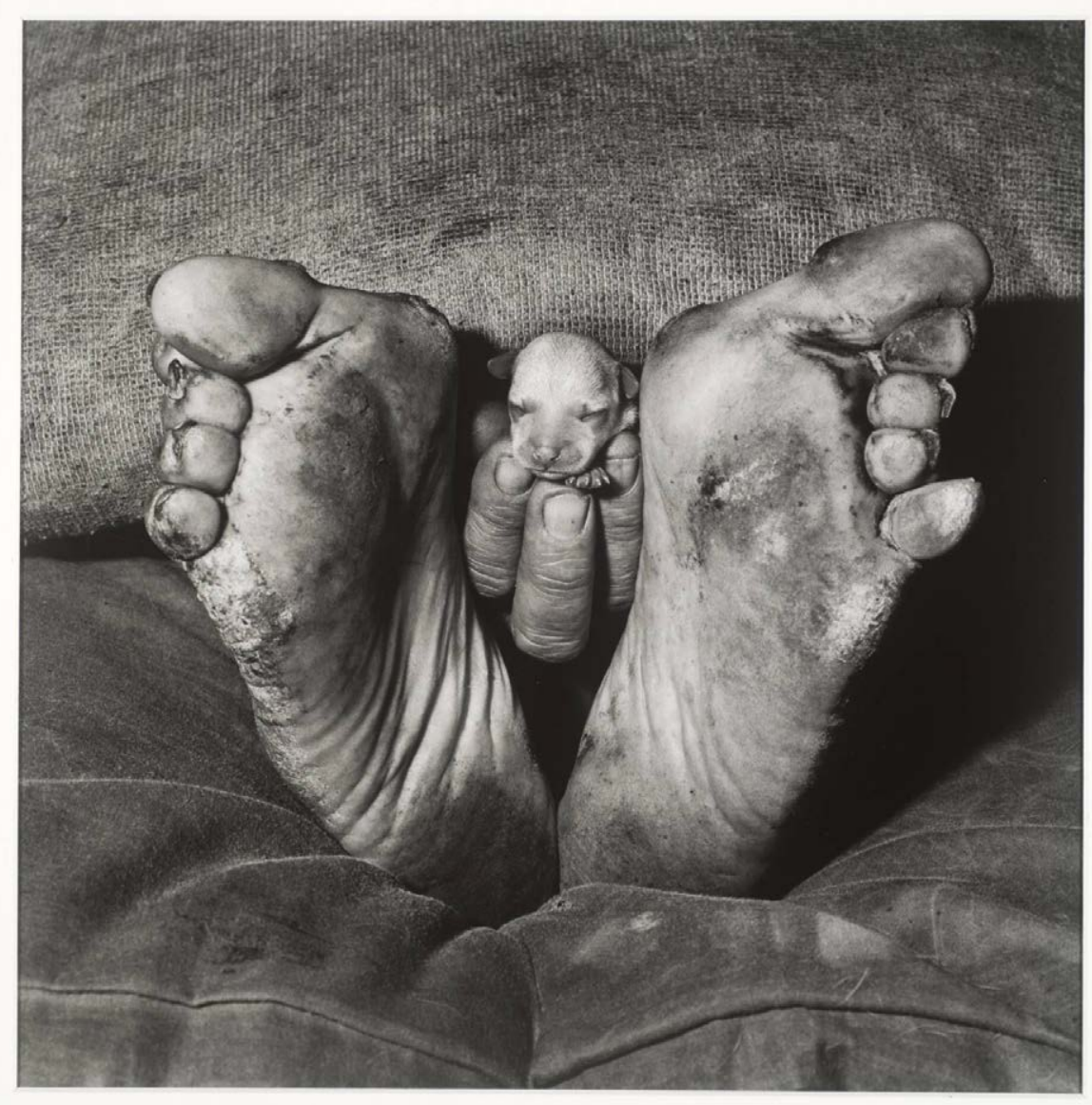

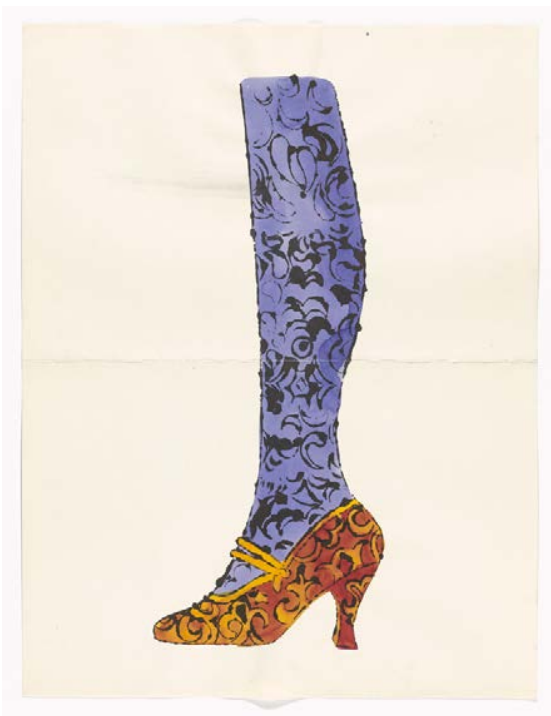

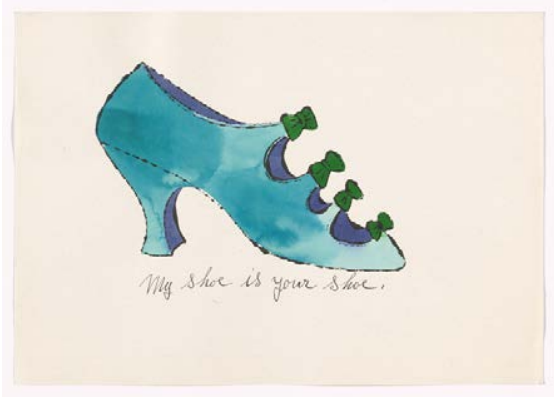

Figura 17 À la recherche du shoe perdu (c1955). Andy Warhol. [Fuente: CMoMA. Museo de Arte Moderno de New York (CAndy Warhol Foundation for the Visual Arts / Artist Rights Society (ARS), New York 459.1999.17/9] 

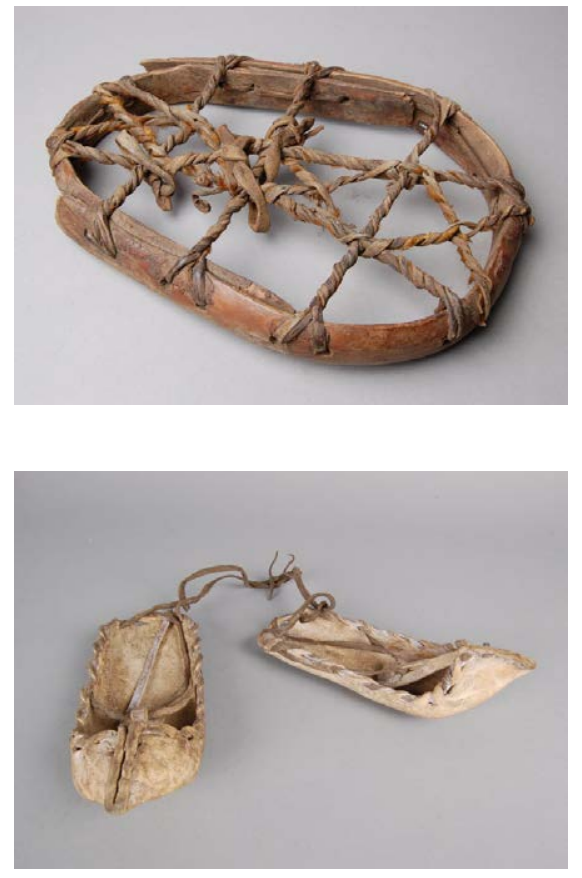

\section{Figura 19 .}

Zapato de nieve de Ladakh

(India) y Zapato (Turquía).

[Fuente: @The British Museum,

Londres]
Figura 20.

Cover from À la recherche du shoe perdu (c1955). Andy Warhol. [Fuente: (OMoMA. Museo de Arte Moderno de New York (C)Andy Warhol Foundation for the Visual Arts / Artist Rights Society (ARS), New York. 459.1999.18]

[24] Rudofsky, Bernard. Behind the picture window. Nueva York: Oxford University Press, 1955. p.
187.

[25] Rudofsky, Bernard. Are clothes modern? An essay on contemporany apparel. Chicago: Paul Theobald, 1947. p. 74.

[26] Ibíd. p. 172.

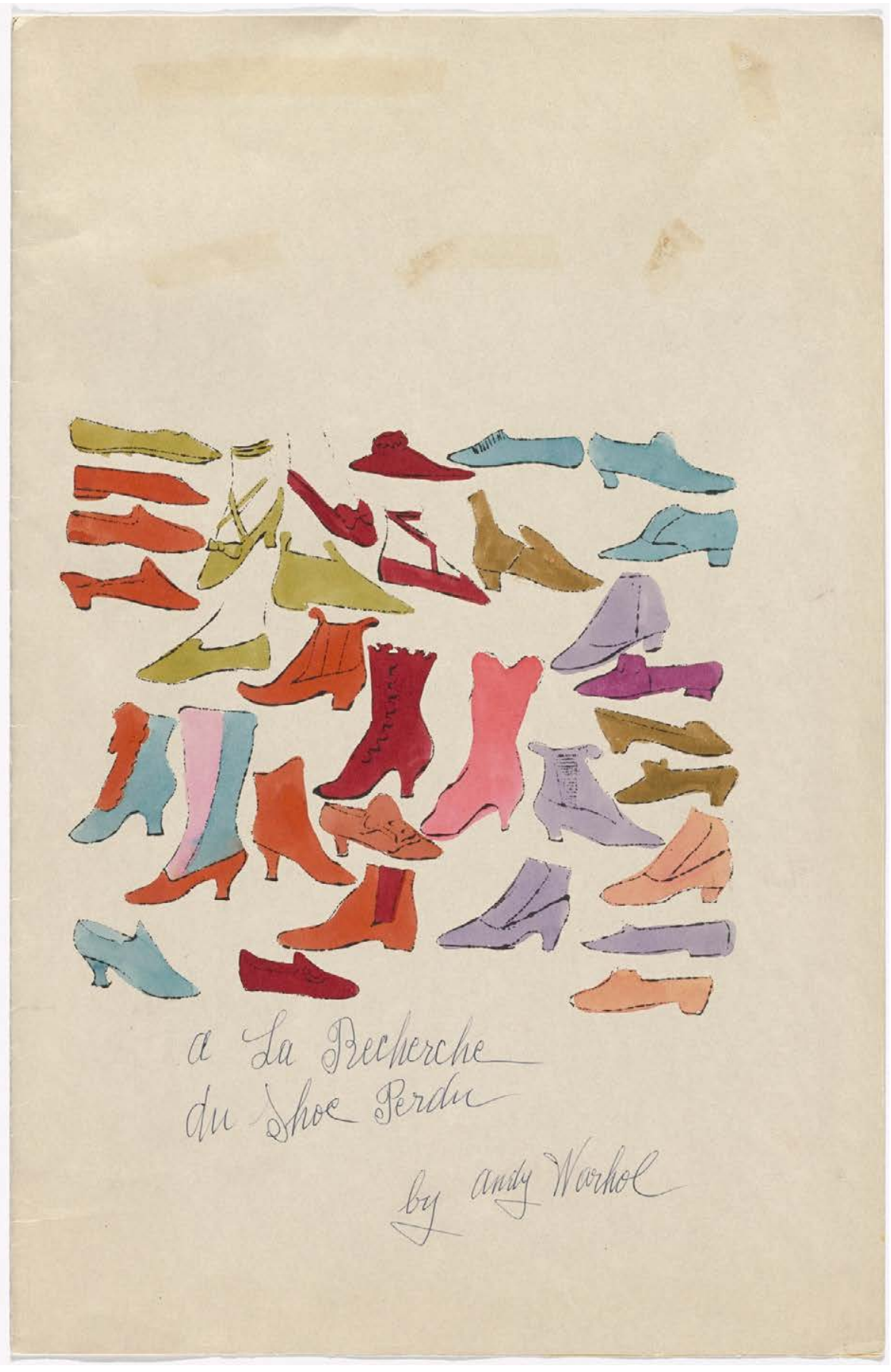

El zapato ha estado históricamente vinculado con el uso y con la función que se le iba a dar, pero sobre todo, con la superficie del suelo donde iba a ser utilizado (fig. 19, fig. 21 y fig. 24). Así el zueco —la almadreña, la amadreña pasiega o la madreña asturiana, la albarca cántabra o abarca, la galocha o la zoca gallega - se trata de un calzado fabricado de forma artesanal de una sola pieza de madera con tres tacos o tacones - dos delanteros y uno posterior-que elevan el calzado del suelo, como se puede ver en el cuadro Filandón en Monasterio de Hermo (1872) de Luis Álvarez Catalá (1836-1901) (fig. 22). Es un zapato cuyo uso se extiende por el norte de España, sobre todo en Cantabria, Galicia, León y el Principado de Asturias. Pero también en Castilla y León, Aragón y Cataluña, en zonas de alta montaña. Los tacones elevaban el pie de la zona húmeda del suelo o de la nieve. Una respuesta semejante a la de algunas arquitecturas, que se elevan para proteger el plano de su suelo (fig. 21). 
De la misma forma ocurre con el zapato de claqué, los zapatos de golf, las botas de fútbol, el zapato de tacón o de plataforma, los mocasines, o las zapatillas de ballet de las bailarinas, ya que cada uno de ellos presenta un tipo de suela, de material, de forma, de flexibilidad o de altura del tacón adecuado para la superficie donde va a ser usado. Así, por un lado el suelo pavimentado impone ciertas exigencias en el uso del zapato adecuado, pero también la obligación de usar un tipo de calzado exige un tipo específico de pavimento.

El arquitecto Bernard Rudofsky (1905-1988) se sentía muy alejado del zapato contemporáneo: «usar zapatos en casa no sólo nos ha hecho indiferentes a la suciedad, también ha mermado nuestro sentido del tacto» [24]. Pero sobre todo se sentía alejado de los diseños de zapatos que obligaban a meter los frágiles pies en lo que él consideraba 'máquinas de tortura personal enmascarados de cuero y tacones de formas seductoras'. En el libro que escribió para la exposición Are clothes modern? celebrada en el MoMA de New York (noviembre 1944marzo 1945), Rudofsky incluyó una ilustración que se presentaba como una crítica al zapato moderno donde se presentaba un modelo de zapato simétrico, y el pie simétrico lógico para utilizar ese tipo de calzado, y junto a ellos, un pie normal asimétrico. Y es que la importancia del zapato radica en que es el elemento que sirve de relación entre el hombre y el suelo.

«El último triunfo de la ropa contemporánea es el zapato simétrico, nuestro mayor remordimiento es nuestra incapacidad para desarrollar un pie simétrico. Si el pie humano tuviera la forma del zapato diseñado para él hoy, tendría el dedo gordo en el medio. De izquierda a derecha: molde de yeso del pie deformado de un adulto que ha tomado la forma de un

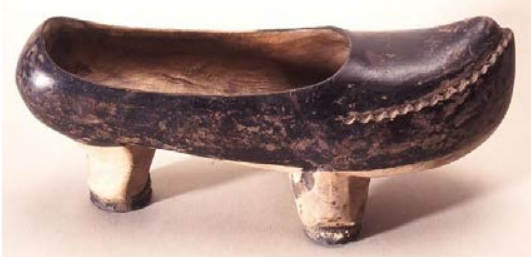

Figura 21 Zuecos. [Fuente: CMuseo Nacional del Traje. Centro de Investigación del Patrimonio Etnológico, Madrid. CE40953]

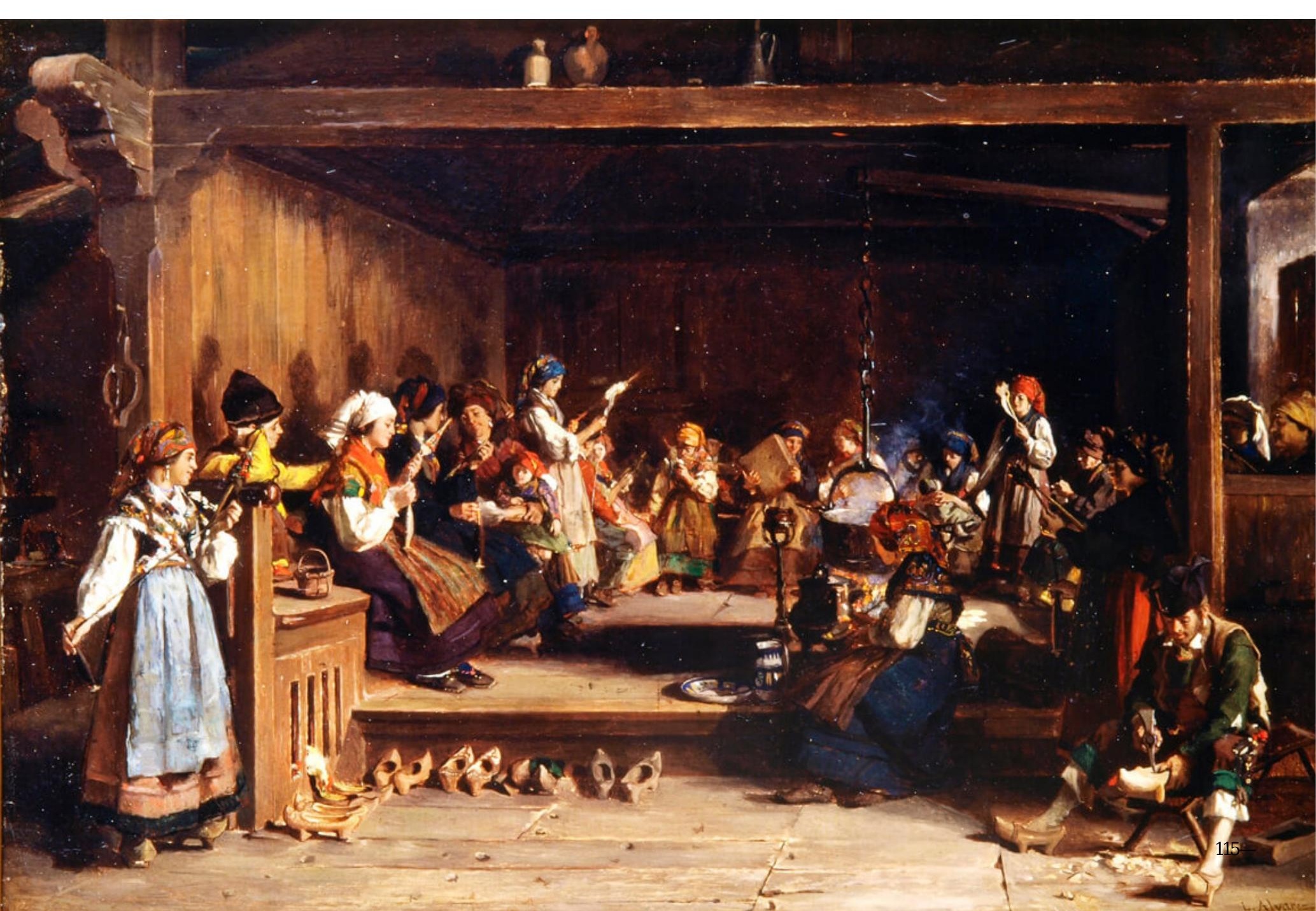

Filandón en Monasterio de Hermo (1872). Luis Álvarez Catalá. [Fuente: @Museo de Bellas Artes de Asturias] 


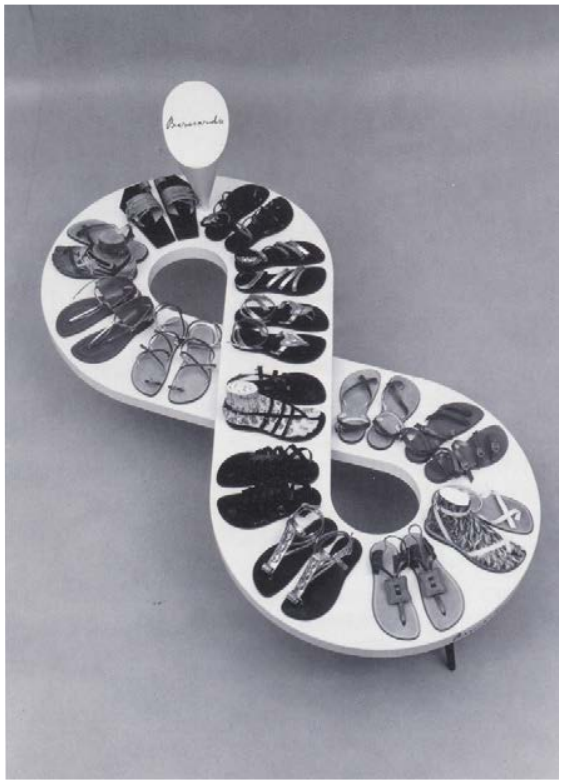

Figura 23.

Soporte con forma de '8' que sirve de Expositor de las

Bernardo Sandals (c1945) de

Bernard Rudofsky. [Fuente:

(C)The Bernard Rudofsky Estate,

Viena]

[27] Rudofsky, Bernard. Architecture without architects: an introduction to non-pedigreed architecture. New York: MoMA-The Museum of Modern Art, 1964.

[28] Loren-Méndez, Mar y Romero-Gómez, Yolanda (eds.). Bernard Rudofsky. Desobediencia crítica a la modernidad. Granada: Centro J osé Guerrero y Diputación de Granada, 2014.

[29] Rudofsky, Bernard. «Non ci vuole un nuovo modo di construire, ci vuole un nuevo modo di vivere (commento al disegno di una casa all'isola di Procida) / We don't need a new way to build. Design proposal for a courtyard villa on Procida island, Italy». Domus. Italy: Editoriale Domus, march 1938, núm. 123, pp. 436-440.

[30] Fernández-Galiano, Luis. «Esparta y Síbaris». El País. Madrid: Ediciones El País y Grupo Prisa, 11 de agosto de 2007.

[https:// elpais.com/ diario/ 2007/ 08/ 11/ opinion/ 11 86783204 850215.html] (01/ 02/2019).

[31] J iménez-Torrecillas, Antonio. «El viaje de vuelta. El encuentro de la contemporaneidad a través de lo vernáculo». Director: Alberto Campo-Baeza. Granada: Universidad de Granada. Escuela Técnica Superior de Arquitectura. Departamento de Expresión Gráfica Arquitectónica y en la Ingeniería 2006

[32] Esta sentencia ya la había usado como título del artículo de la revista Domus de marzo de 1938:

Rudofsky, Bernard. 1938. Op. Cit.

[33] Fernández-Galiano, Luis. Op. Cit.

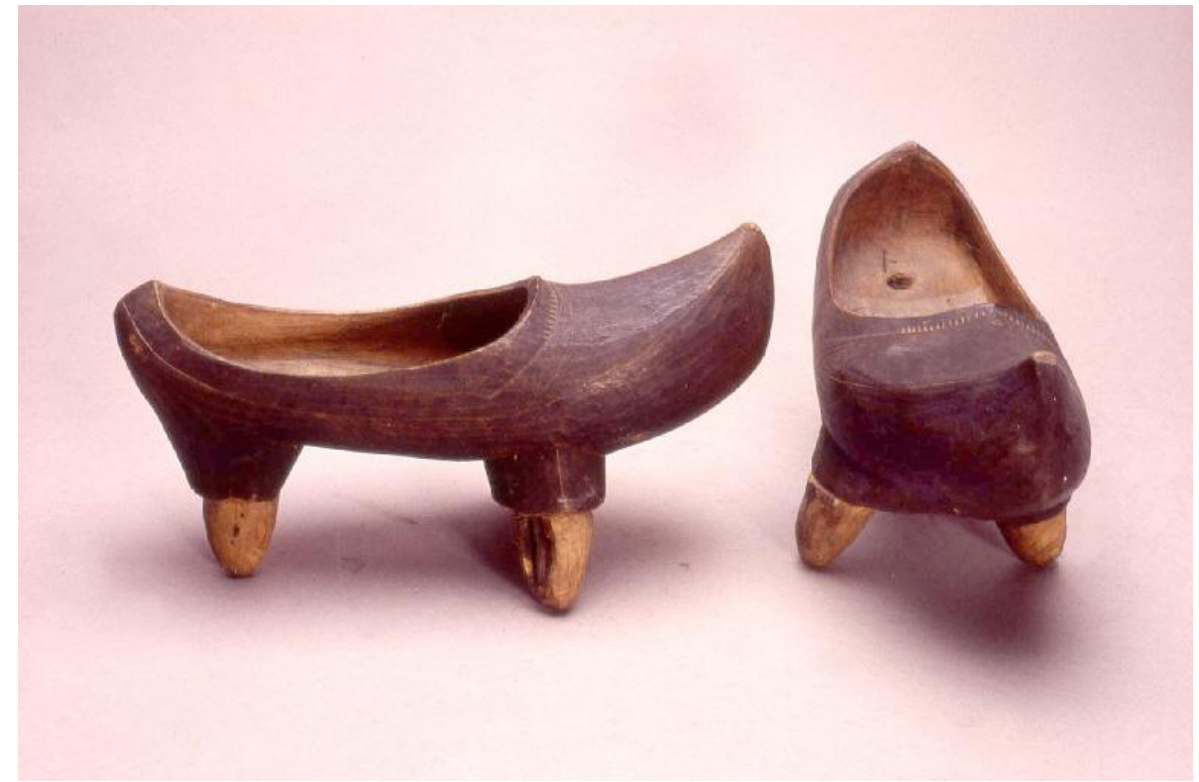

zapato; zapato de madera; zapato actual; modelo de yeso de un pie imaginario simétrico que corresponde a la idea del fabricante de calzado de la anatomía humana».[25].

«A specific feminine gait has been artificially engineered with the help of various and often ingenious implements. Extreme weight and height and, more recently, non-essential heels were added to a woman's shoe in order to throw her out of balance» [26].

Bernard Rudofsky (1905-1988) tenía algo de hombre renacentista, interesado por la modernidad que le tocó vivir, pero poniéndole los límites oportunos para evitar lo que para él podrían ser unas «letales consecuencias» debido al imparable proceso de industrialización y globalización. Como pensador, defendía la tradición vernácula, como se pudo comprobar en la exposición Architecture without architects celebrada en el MoMA de New York (noviembre 1964-febrero 1965) y el catálogo convertido en best-seller [27], si bien al principio fue recibido con recelo por las élites de la modernidad. En él, reclamaba una nueva sensibilidad hacia el paisaje, el lugar y las costumbres, pero desde una mirada moderna [28], trazando un recorrido fotográfico por las arquitecturas populares y vernáculas - pero sobre todo anónimas y espontáneas- de todo el mundo, incluidos sus suelos y pavimentos. Es decir, la arquitectura debía ser «una disciplina integrada en el arte de vivir» [29].

Un año después de la la exposición Are clothes modern? celebrada en el MoMA de New York (noviembre 1944-marzo 1945) y alentado por Diana Vreeland (1903-1989) de la revista Vogue, en 1946 Rudofsky fundó la marca Bernardo de fabricación de sandalias: las Bernardo Sandals (fig. 23 y fig. 27). De algún modo, pretendía la liberación del pie del calzado confinado de la década de 1940. En ellas se «combinaba la desnudez escueta de lo vernáculo y lo moderno con una exaltación del confort natural y el hedonismo espontaneo, lindante con la perversión en las cadenitas ocultas que unen rodillas y tobillos» [30]. La primera colección se inauguró en el Hotel Riz Carlton de Manhattan en New York con seis diseños. El éxito fue inmediato. Aparecieron reportajes y anuncios en las revistas de moda de la época como Vogue o Harpers Bazaar y fueron usadas por iconos como Jacqueline Kennedy Onassis (1929-1994). Todavía hoy se siguen comercializando. 


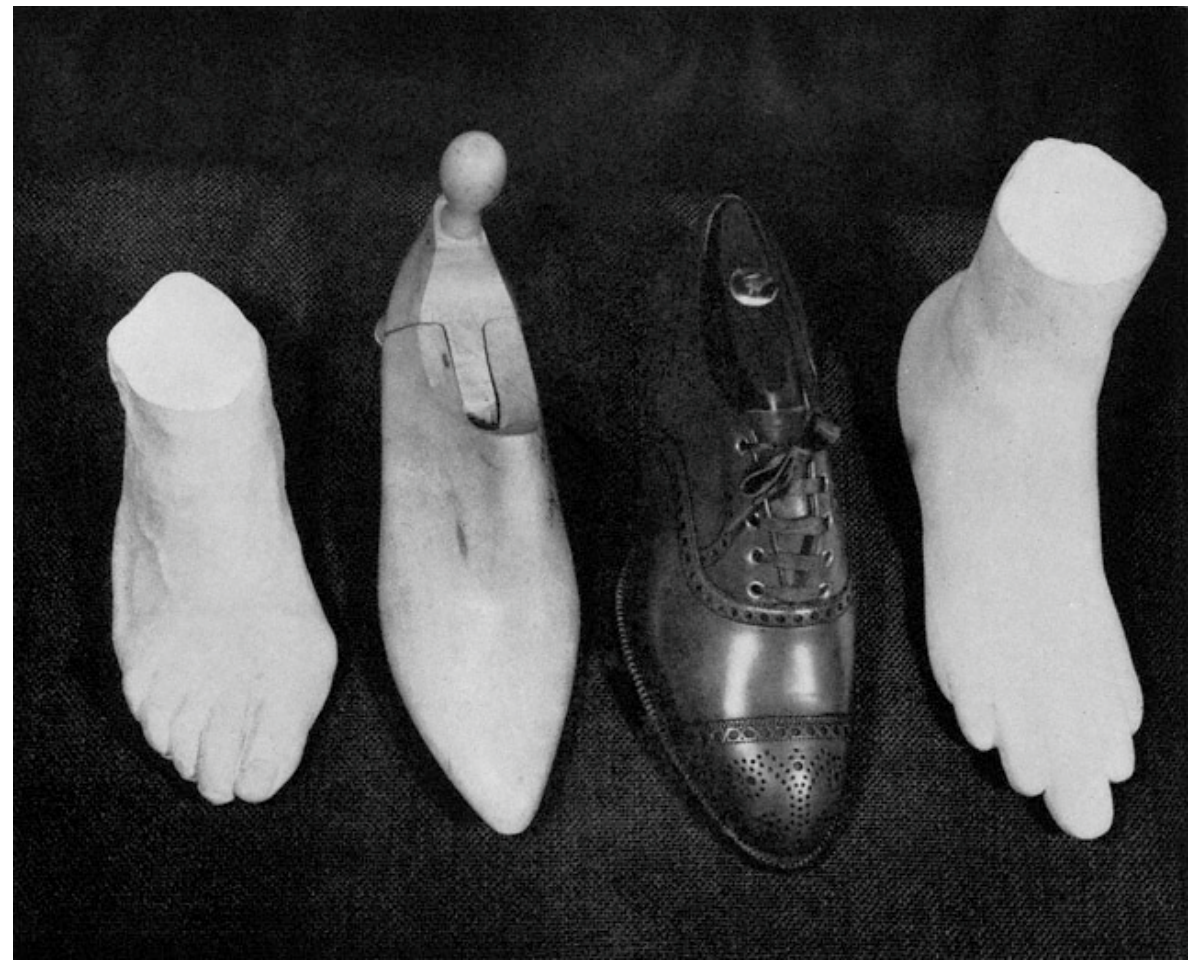

Unos años más tarde, pero influenciado por Rudofsky, el arquitecto Antonio Jiménez Torrecillas (1962-2015) en su Tesis doctoral El viaje de vuelta. El encuentro de la contemporaneidad a través de lo vernáculo (2006) [31] nos desvela cuánto la tradición vernácula sigue todavía siendo una fuente de conocimiento para el arquitecto comprometido con lo contemporáneo. En la Tesis, a través de su generoso álbum fotográfico obtenidas durante sus viajes por todo el mundo, Jiménez Torrecillas deposita su mirada en las arquitecturas populares y en los paisajes, pero también sobre los pavimentos realizados por constructores anónimos. En las fotografías que ilustran su trabajo de investigación se pueden ver pavimentos desprendidos de la pátina de la disciplina, suelos frescos de piedras irregulares del lugar, superficies continuas de mortero de cal.

Tanto en los estudios de Rudofsky como en los de Torrecillas se ponía la atención en la inteligencia —constructiva y emocional—, en la sostenibilidad —ambiental y energética - y en la austeridad —económica y de medios- de la arquitectura popular.

El título de su última exposición —que inauguró en el Museo Austriaco di Arti Applicate di Vienna (MAK) unos meses antes de morir, en 1988- era una síntesis de su ideario: Sparta/Sybaris. Keine neue Bauweise - eine neue Lebensweise tut not (Sparta/Sybaris. Lo que hace falta no es una nueva forma de construir, sino una nueva forma de vivir) [32]. Seguramente ahí residía la felicidad: en tener la habilidad de multiplicar el placer con actos sencillos [33]. Es decir, en situarse en la mediana que une por igual a las actitudes espartanas con el deseo sibarita. Un manifiesto que Rudofsky aplicaba a la vida y a la arquitectura en general, y a su mirada sobre los pavimentos en particular.

Pero a pesar de todo, quizá por el momento que le tocó vivir y, desde luego por la auto-censura, nunca llegó a desarrollar del todo estas observaciones. En las casas que diseñó, no terminó de fomentar el placer táctil de la utilización de materiales rugosos con superficies irregulares. Tampoco en la casa 'La Parra' que se construyó en Frigiliana (Málaga), en el sur de España (fig. 28) [34].

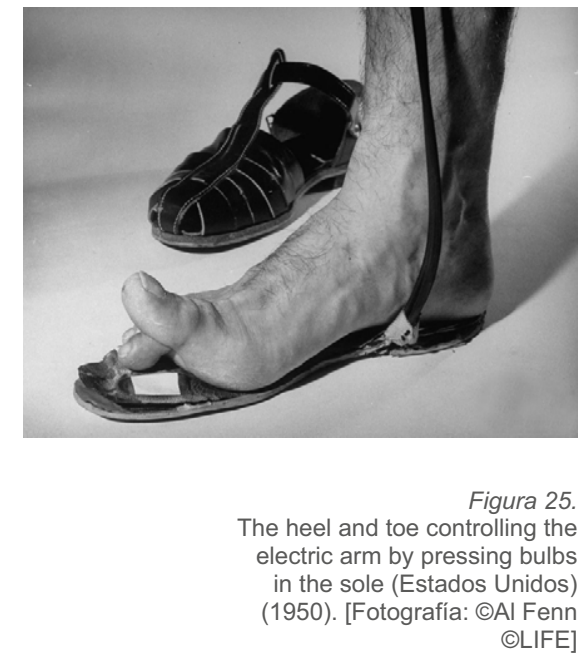

Figura 26.

Fotografía incluida en la exposición Are Clothes

Modern? del MoMA de New

York (1964-1965) de Bernard

Rudofsky. [Fuente: @Barbara

Sutro @MoMA. Museo de Arte

Moderno de New York]
Figura 27.
Bernardo Sandals (c1945) de
Bernard Rudofsky. [Fuente:
The Bernard Rudofsky Estate,
Viena]

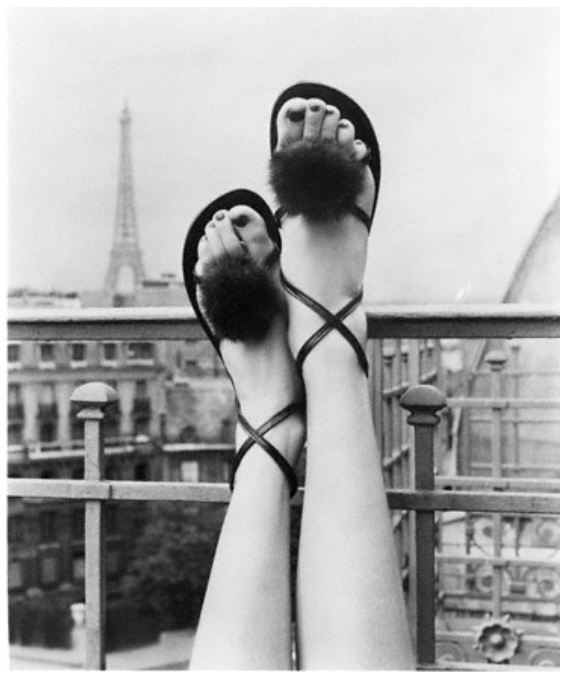




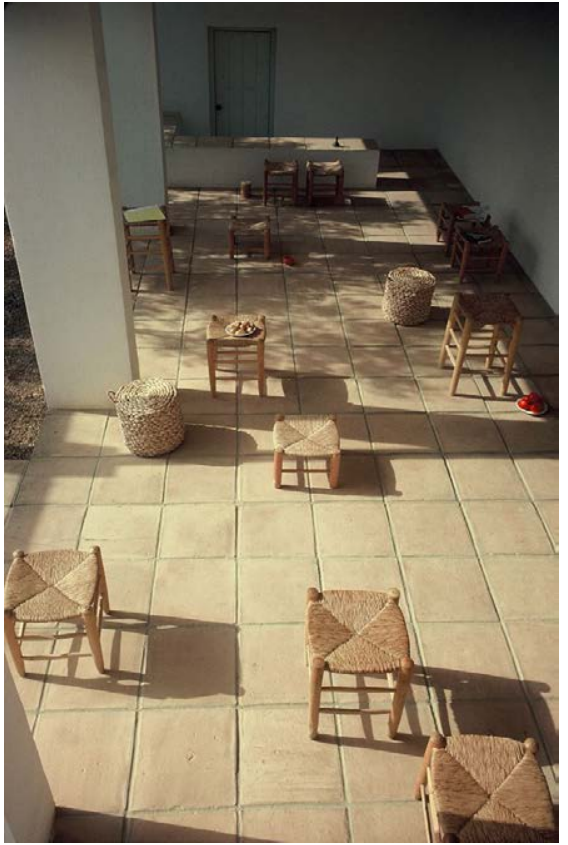

Figura 28.

Fotografía del pavimento

exterior de un porche de la

casa 'La Parra' en Frigiliana

(Málaga). (1969-1971).

[Fotografía: @Bernard Rudofsky

CThe Bernard Rudofsky Estate,

Viena]

[34] Bocco-Guarneri, Andrea. «Un catálogo de posibilidades. Un viaje por las ideas rudofskianas sobre la Lebensweise». En: Loren-Méndez, Mar y Romero-Gómez, Yolanda (Ed.). Bernard Rudofsky. Desobediencia crítica a la modernidad. Granada: Centro J osé Guerrero y Diputación de Granada, 2014. p. 96.

[35] Demetrion, James T; Cooke, Susan J .; Planque, J ean; Schjeldahl, Peter. Jean Dubuffet, 19431963. Paintings, Sculptures, Assemblages.

Washington: Hirshhorn/ Smithsonian, 1993. p. 120.

[36] La pieza fue grabada y editada en un video a color de seis minutos. Se mostró en exposiciones, generalmente en un monitor de televisión.

Hatoum, Mona. Roadworks. [video VHS, colour $6 \mathrm{~min} 45 \mathrm{~s}$ ]. París: Collection Centre Pompidou, Musée National d'art moderne, 1985.

[37] Perrot, Capucine. «Mona Hatoum, Performan ce Still 1985-95». Performance At Tate: Into the Space of Art. Londres: Tate Research Publication, 2016.

[http:// www.tate.org.uk/ research/ publications/ pe rformance-at-tate/ perspectives/mona-hatoum] (06/04/2018).

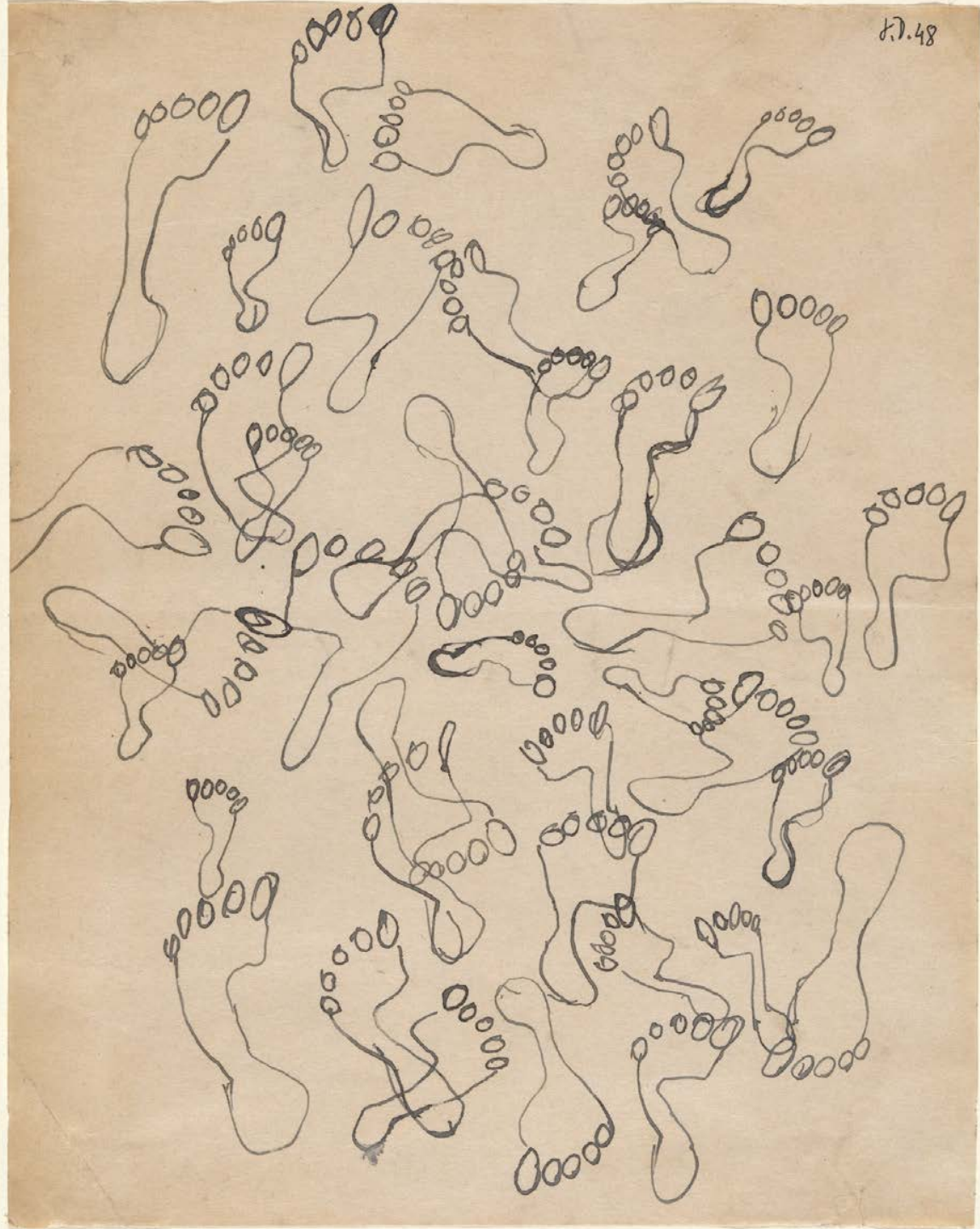

Si como hemos comentado, Rudofsky se sentía muy alejado del zapato contemporáneo, no lo sería menos de algunas tradiciones milenarias asiáticas. En China, los 'pies vendados' (pies de loto) era la costumbre de aplicar una venda muy ajustada a los pies de las niñas, con la voluntad de controlar su crecimiento y constreñir su forma (fig. 31). La práctica tuvo su origen entre las bailarinas de la aristocracia de la dinastía Song de China (960-1279) durante el siglo X. Posteriormente, las familias de clase media, vendaban los pies a las hijas mayores con la voluntad de convertirlas en una dama y tuviera facilidades para tener un matrimonio ventajoso, ya que para los hombres, el pie de loto resultaba muy atractivo. Las familias más humildes o las hijas menores, cuyo destino era irremediablemente dedicarse al servicio de los demás o a la agricultura, no se vendaban el pie, ya que les impediría realizar trabajos de fuerza.

Para algunos hombres, uno de los principales efectos eróticos de los 'pies de loto' era el 'andar de loto': es decir, caminar dando pequeños pasos, oscilantes y frágiles. Y es que las mujeres con los 'pies de loto' evitaban poner el peso del cuerpo en la punta del pie, lo que provocaba que se apoyaran, en los talones. Otros maridos, preferían no ver nunca los pies desnudos de los 'pies de loto' de su esposa, y preferían verlos ocultos dentro de los 'zapatos de loto': unos zapatos, fabricados de algodón o seda, que tenían forma de cono e intentaban 
representar el capullo del loto. Según Feng Xun: «Si quitas los zapatos y las vendas, el sentimiento estético será destruido por siempre».La práctica se prolongó durante los siguientes siglos, hasta el siglo XIX, donde hubo algún conato de renacimiento; y finalmente durante el siglo XX la costumbre desapareció, salvo en algún lugar que se seguía aplicando de forma anecdótica. En 1949 el gobierno comunista de Mao Zedong (1893-1976) lo prohibió definitivamente. Rudofsky incluyó en el catálogo de la exposición Are clothes modern? celebrada en el MoMA de New York (noviembre 1944-marzo 1945), unas fotografías y una radiografía de un 'pie vendado' chino como una prueba más del sufrimiento al que se le ha sometido al pie a lo largo de la historia (fig. 31).

En la obra del artista Jean Dubuffet (1901-1985) también encontramos referencias a los pavimentos entendidos como superficies holladas. Después de su estancia en El Goléa, un oasis en el desierto de El Sáhara, ya sugiere la inspiración que encontraría bajo sus suelas durante las próximas décadas. De esta época son la serie de bocetos donde representa decenas de huellas de pies humanos superpuestas sobre una hoja de su cuaderno Footprints, (page from the sketchbook) El Golea, II (1948) (fig. 29).

Este interés por el plano del suelo lo demostró también en la exposición Topographies and texturologies (1957): «¡Mira lo que está a tus pies! Una grieta en el suelo, grava brillante, una mata de hierba, algunos escombros aplastados, todos ofrecen temas igualmente dignos para su aplauso y admiración» [35]. En su obra investiga la noción de sitio y muestra el pavimento que nos encontramos bajo nuestros pies, invitando a un escrutinio más cercano de la textura de la ciudad. Así encontramos Soul of the Underground (1959), Chaussée grise y Chaussée urbaine mouillée (1957). A veces, estas texturas las representaba atribuyéndole rasgos humanos: cabeza, ojos, cuerpo, como en el caso de La Vin en Barbe (1959).

En la obra Performance Still (1985) (fig. 30) de la artista Mona Hatoum (1952-) y extraída como fotograma de un video [36], ella misma caminaba descalza, durante casi una hora, por las calles de Brixton en Londres, pero con unas botas Doc Marten —utilizadas tanto por la policía como por grupos marginales- atadas a los tobillos. En la obra, que habría sido del agrado de Rudofsky, el calzado podía entenderse como el significante de la condición que mantiene a alguien bajo control: un símbolo de opresión [37].

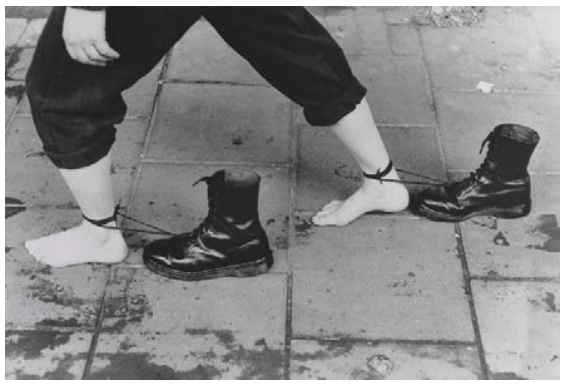

Figura 30

Performance Still $(1985,1995)$. [Fuente: CTATE, Londres. P80087]
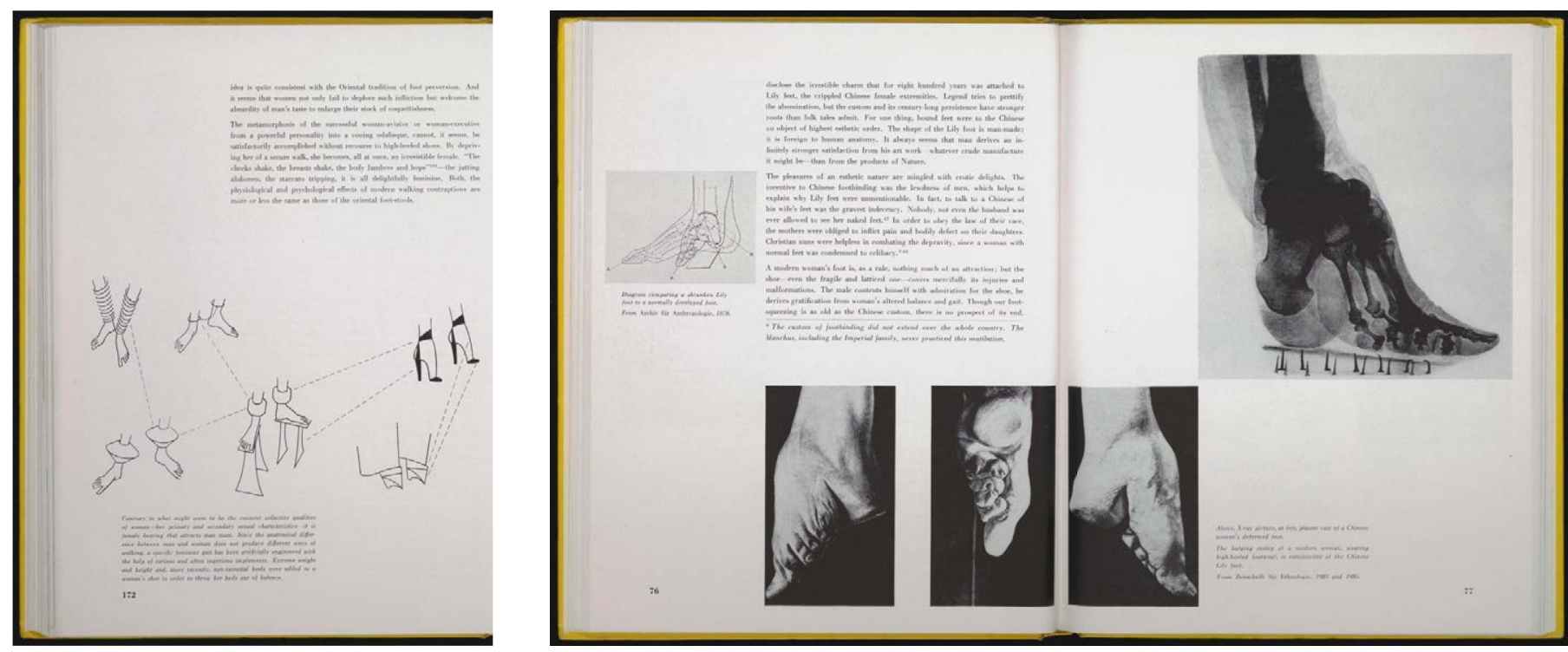


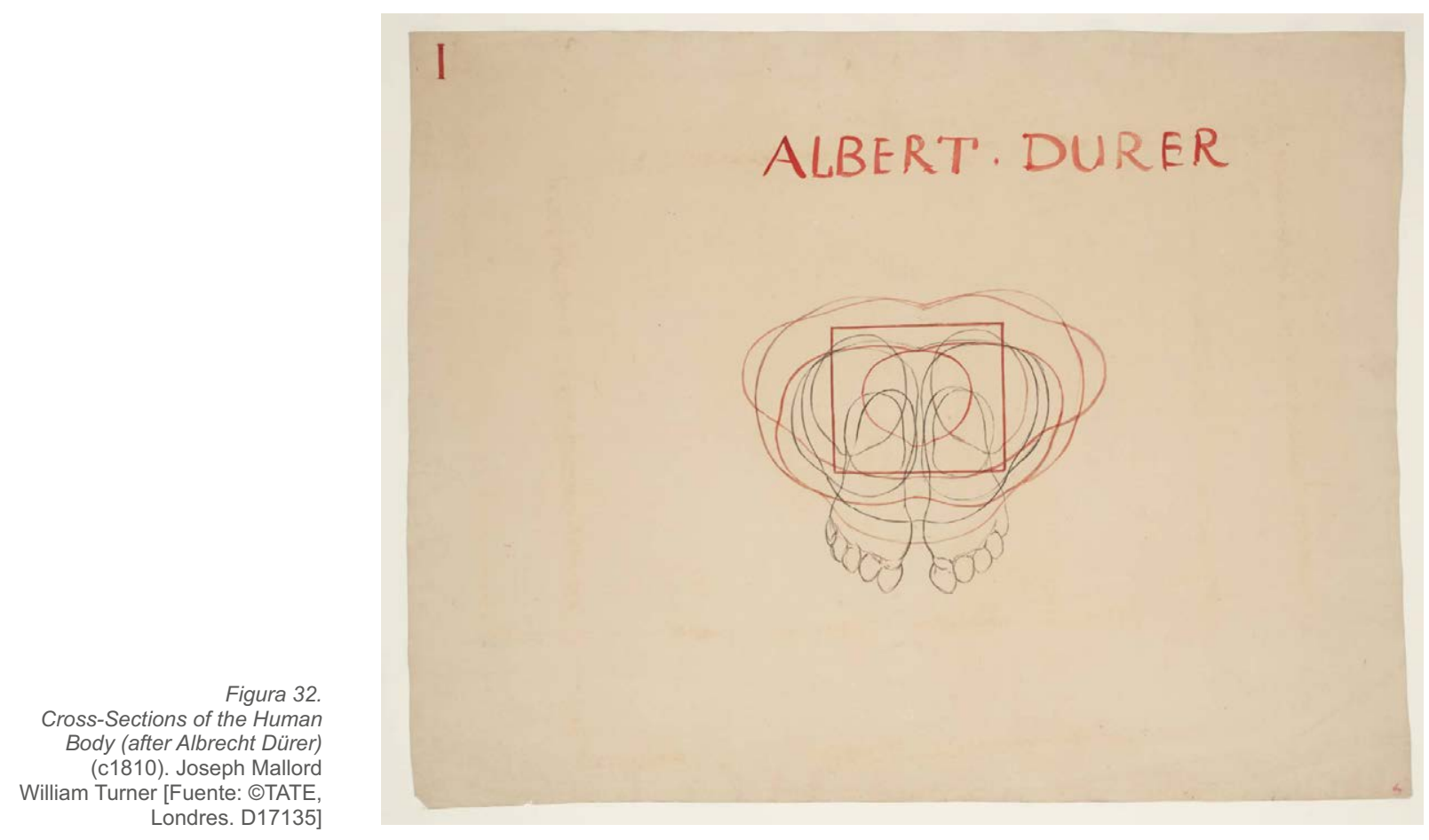

\section{Antropometría del pie}

En el diagrama Cross-sections of the human body (después de Albrecht Dürer) (c1810) (fig. 32) de Joseph Mallord William Turner (1775-1851), intentaba mostrar que las formas geométricas se pueden encontrar en el cuerpo humano. Lo hacía en la primera lección como profesor de perspectiva en la Royal Academy. Basado en una ilustración del libro Four books on the proportion of the human body (1528) de Albrecht Dürer (Durero) (1471-1528), se secciona una figura humana, desde los pies a la cabeza, superponiendo todos esos cortes en un dibujo visto cenitalmente. Y éste, a su vez, tomaba como referencia a Marco Vitruvio Polión (c80-c15 a.C.). El tema de las proporciones y del estudio de las medidas del cuerpo humano — también del pie — ha sido recurrente a lo largo de la historia.

[38] Tilley, Alvin R. y Dreyfuss Associates, Henry. The Measure of Man and Woman: Human Factors in Design. New York: The Whitney Library of Design, 1960.

[39] 1a. Medidas corporales, 1b. Mediciones de enlace, 2a. Guia de asientos, 2b. Guía de asiento/mesa, 3a.Usuarios de sillas de ruedas, $3 \mathrm{~b}$. Discapacitados y ancianos.

[40] 4a. Fuerza humana, 4b. Seguridad, 5a. Controles de manos y pies, $5 \mathrm{~b}$. Muestra, 6a. Cabeza y visión, $6 \mathrm{~b}$. Manos y pies.

[41] 7a. De pie en el trabajo, 7b. Sentado en el trabajo, 8a. La planificación del espacio, 8b. Espacio público, 9a. Acceso al cuerpo, 9b. luz y color.

[42] Pallasmaa, J uhani. Los ojos de la piel. La arquitectura y los sentidos. Puente-Rodríguez, Moisés y Muro, Carles (trads.). Barcelona: Editorial Gustavo Gili, 2014.

Pallasmaa, Juhani. The Eyes of the Skin. Architecture and the Senses. Chichester, UK, 2012.

[43] Zumthor, Peter. Atmospheres: Architectural Environments - Surrounding Objects. Berlín: Birkhäuser, 2006.
Unos años más tarde, en 1960 se publicó el libro The Measure of Man and Woman: Human factors in Design [38] que dio origen a las plantillas publicadas a partir de 1974: Humanscale, diseñadas por Henry Dreyfuss Associates y Niels Diffrient -y con diseño gráfico de Valerie Pettis- que servían de herramienta para todos aquellos diseñadores que se relacionaban con el cuerpo humano: arquitectos, ingenieros industriales o diseñadores de moda, entre otros (fig. 34). Las plantillas fueron el fruto de una extensa investigación coral entre antropólogos, médicos y científicos. Las tablas trazan las medidas del cuerpo humano y cómo se relaciona éste con el espacio que le rodea. Disponían de 60.000 bits de datos sobre estadísticas ergonómicas o antropometría, cubriendo un amplio abanico de información sobre mediciones corporales, sobre los modos de sentarse o de estar de pie.

Las plantillas estaban agrupadas en tres conjuntos separados (Humanscale 1/2/3 [39], Humanscale 4/5/6 [40] y Humanscale 7/8/9 [41]) (fig. 34), cada uno de ellos incluye un folleto y tres selectores de doble cara que contenían un disco giratorio con los datos intrincados que permitían establecer los atributos de la persona para la que se iba a diseñar. En las plantillas están representados hombres y mujeres, niños y ancianos, así como discapacitados. Mientras que 
algunos datos han cambiado desde la década de 1970 —debido a la evolución de las dimensiones humanas - resulta sorprendente que la mayor parte de la información sigue todavía ofreciendo un valioso punto de partida para diseñadores o arquitectos. En definitiva, se trataba de ayudar a los diseñadores para optimizar el confort, la salud y la seguridad humana. Utilizadas para el diseño de casi todo, desde la ropa y los zapatos, hasta las sillas, los vehículos o los cascos; pero también para el diseño de espacios arquitectónicos. Además, son una referencia valiosa de las dimensiones del cuerpo humano, y desde luego del pie. Así, en la plantilla 6b Humanscale: Hands and Feet, se muestra una amplia información sobre las dimensiones y forma del pie humano presentado desde todas las vistas posibles: planta, alzados laterales, frontal y trasero.

\section{El pavimento como espacio sonoro y como campo de baile}

El suelo pavimentado es también un espacio sonoro, una atmósfera acústica que absorbe, reflecta o reverbera los sonidos. Y es que el sonido —también su ausencia en forma de silencio- irremediablemente nos envuelve y construye un paisaje sonoro inevitable. Si la vista es un sentido unidireccional, donde el observador puede sentirse un ser solitario, el oído establece vínculos de contacto y solidaridad con los demás o con los elementos.

"La vista aísla mientras que el sonido incluye; la vista es direccional mientras que el sonido es omnidireccional. El sentido de la vista implica exterioridad, pero el sonido crea una sensación de interioridad. Contemplo un objeto, pero el sonido me llega; el ojo alcanza, pero el oído recibe. Los edificios no reaccionan a nuestra mirada, pero nos devuelven nuestros sonidos al oído» [42].

El sonido nos advierte, nos informa, nos previene, nos comunica distancias y, desde luego, nos rememora acontecimientos o recuerdos. El sonido es un hecho cultural que heredamos. En cada época el sonido ha terminado por formalizar a la arquitectura. Peter Zumthor (1943-) cree que los edificios siempre suenan, incluso suenan sin emociones [43].

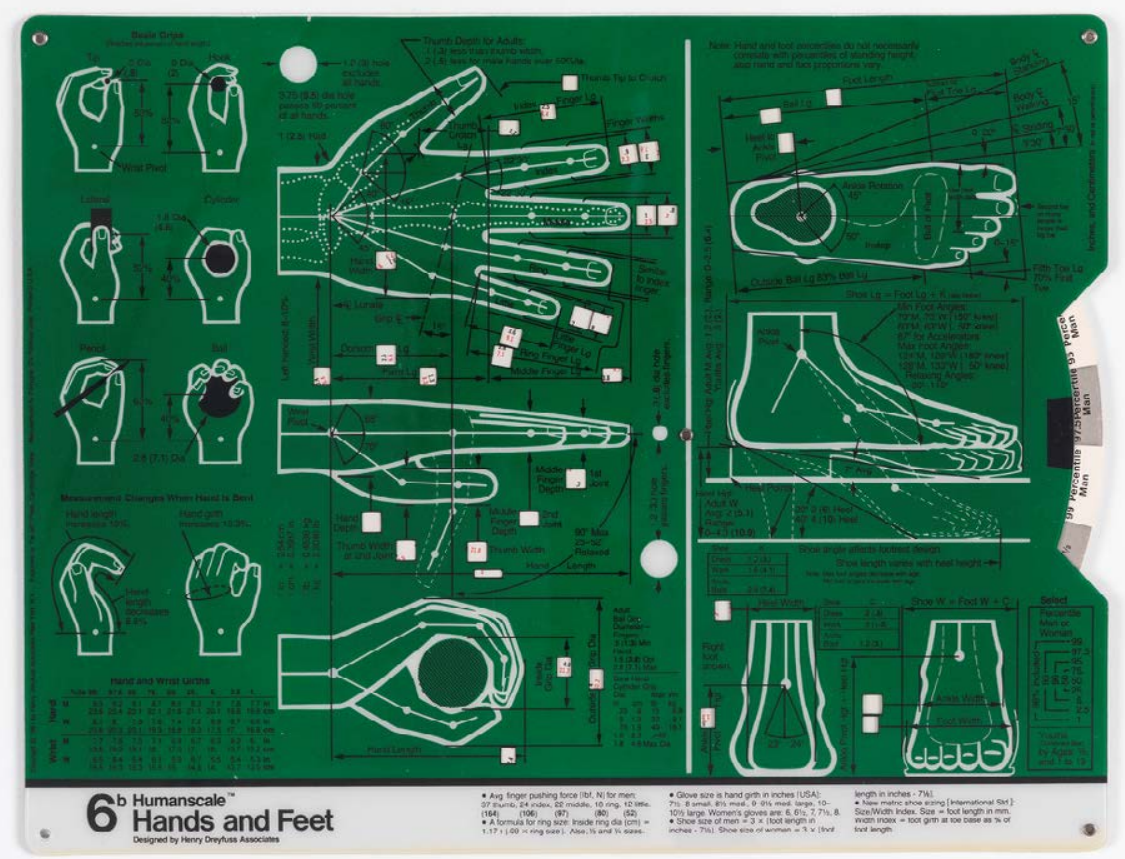

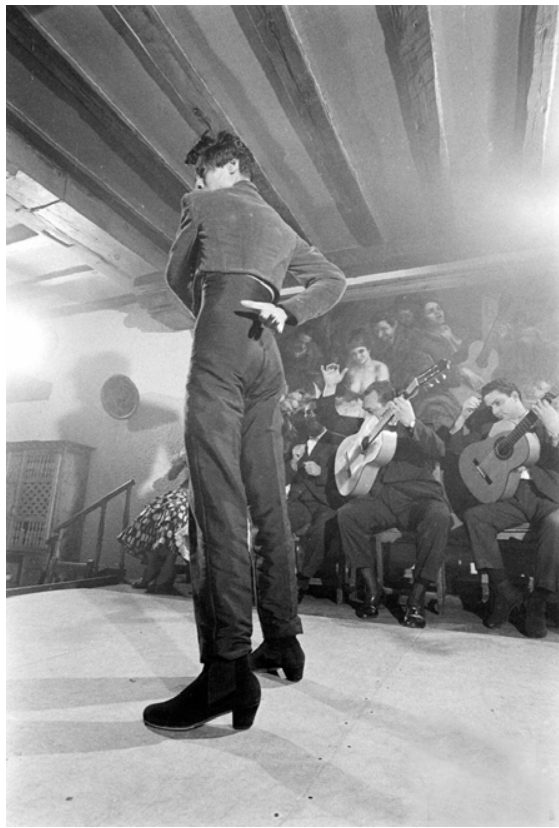

Figura 33 Bailaor' flamenco bailando sobre un tablao' en Madrid (España) (1960). [Fotografía CLoomis Dean CLIFE] Plantillas Humanscale (1974) [Fotografía: ClaCollaborative CHenry Dreyfuss Associates]
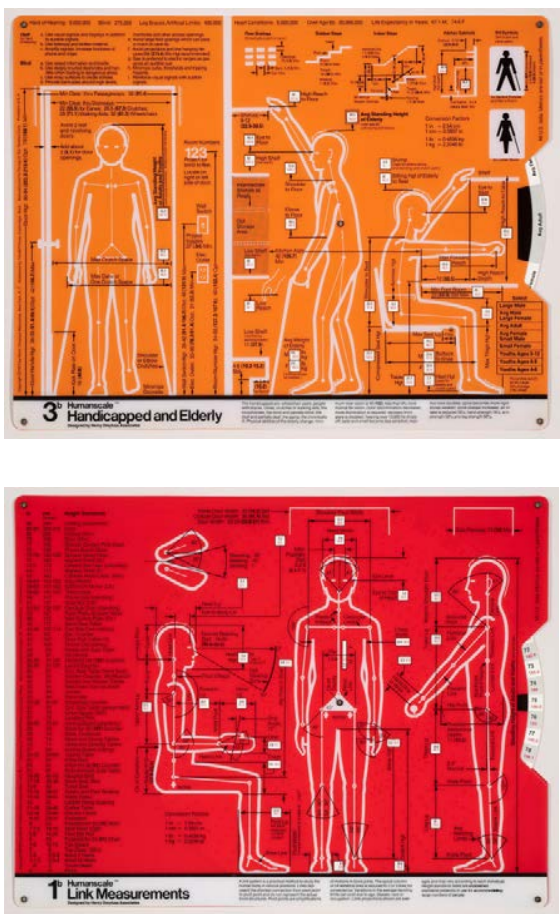


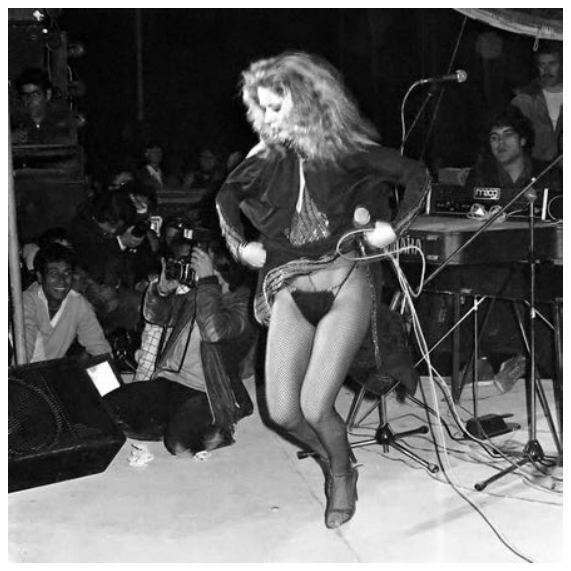

Figura 35.

La cantante María Jiménez bailando sobre un tablao'

flamenco (1980). [Fotografía:

CPablo Juliá]

Figura 36.

a bailarina Nita Bieber interpretando un energético número «Native Voodoo» sobre la pista de baile de un club nocturno en la pelicula Nance Goes to Rio (1949). [Fotografía: CAlfred Eisenstaedt @LIFE]

[44] Moro, J osé-Luis. Flooring. Volume 2. Design. Life cycle. Case Studies. Berlín: DETAIL Practice Book e Institut für internationale ArchitekturDokumentation GmbH \& Co. KG, 2016.

[45] Fernández-Galiano, Luis. «Treinta y dos ele mentos. Architecture, from System to Fragment. Suelo. Del piso al pavimento». Arquitectura Viva. Elements/Elementos. Madrid: Editorial Arquitectura Viva, diciembre 2014, núm. 169, pp. 11-60.

[46] Pallasmaa, Juhani. Los ojos de la piel. La arquitectura y los sentidos. Puente-Rodríguez, Moisés y Muro, Carles (trads.). Barcelona: Editorial Gustavo Gili, 2014

Pallasmaa, J uhani. The Eyes of the Skin. Architecture and the Senses. Chichester, UK, 2012.

[47] Koolhaas, Rem (ed.) y Easterling, Keller. «Floor». En: Elements of architecture. The Venice Biennale. 14th International Architecture Exhibition. Venezia: Marsilio Editori, 2014. p. 52.

[48] «Nightingale floor, Uguisubari».Zen-Garden. [http://www.zen-

garden.org/ html/page nightingalefloor.htm] (02/02/2019)

[49] Koolhaas, Rem (ed.) y Easterling, Keller. Op. Cit. p. 55.
Aunque el sonido se transporta por el aire, se transfiere también a través de la vibración del suelo del piso. Si bien los muros y el techo pueden librarse del contacto físico humano, sobre el plano horizontal del suelo, el hombre tiene la obligación de moverse [44]. El suelo, y por extensión el pavimento, pueden considerarse como arquitecturas de contacto. Cada pisada es un acontecimiento fundamental en la experiencia háptica [45]. «Sentimos placer y protección cuando el cuerpo descubre su resonancia en el espacio» [46].

El instrumento de percusión del suelo entendido como recinto sonoro son los pies —con o sin zapatos- (fig. 35, fig. 36 y fig. 37) Así, la materialidad del pavimento y la elección del zapato producen un sonido que permite informar a los demás del tipo de espacio que se habita, de la ceremonia que acontece y del poder del protagonista que se desplaza con sus zapatos o sin ellos. Los sonidos de las pisadas también ofrecen una información sobre los privilegios o deberes de alguien. Incluso sobre su estado de ánimo. Mientras que en la cultura japonesa se desarrolla una forma de caminar especial para evitar incluso el susurro de los pies sobre el tatami, otras culturas golpean ruidosamente sus

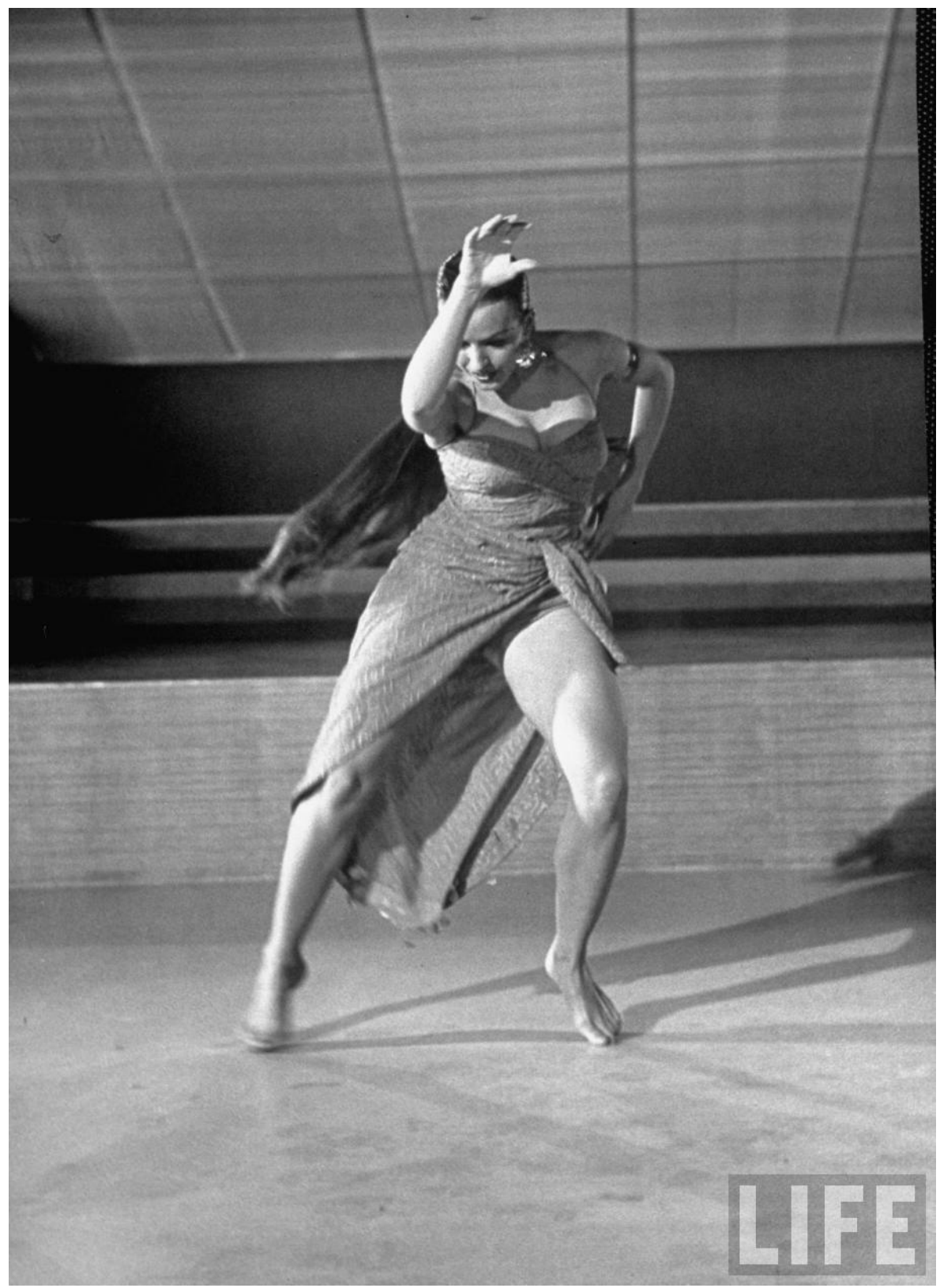




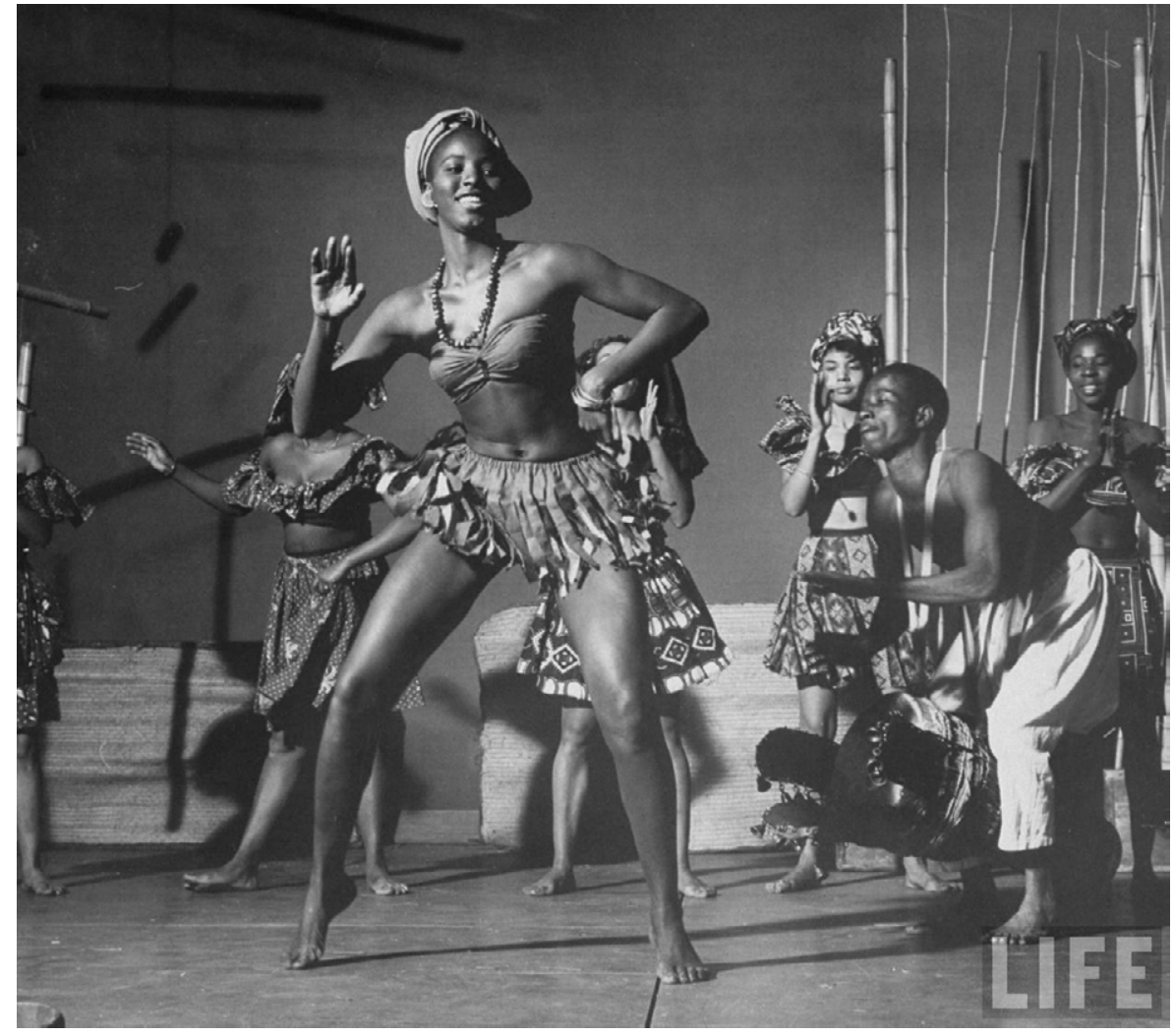

suelos o incluso desarrollan nuevos tipos de zapatos. Así, los zapatos de tacón, cuando quien los lleva se desplaza por el suelo con ellos, además de elevar a quien los porte, ofrecen sonidos intimidatorios de autoridad jerárquica, militar, política o empresarial [47]. E irremediablemente participan de las relaciones de atracción que se establecen entre semejantes. Esta mezcla de poder y de placer la representó bien el diseñador gráfico Juan Gatti (1950-) en el cartel de la película 'Tacones lejanos' (1991) de Pedro Almodóvar (1949-), donde se representa a una pistola que — paradójicamente apuntando hacia el suelo- sustituye el tacón y sostiene un exagerado zapato de cuero negro brillante sobre un fondo neutro de color rojo (fig. 38).

Los suelos de Nightingale (Uguisubari en japonés) [48] eran un dispositivo de seguridad utilizado en Japón cuyo origen se sitúa en el siglo XVII (fig. 39). Se construyeron en los pasillos de algunos templos y castillos, como en el Palacio de Ninomura en el Castillo de Nijô (1603), en el Templo Chion-in, en el Templo de Eikan-dô Zenrin-ji, o en el Templo de Daikaku-ji, todos en Kyoto. Aparentemente se trataban de entarimados normales, pero las tablas de madera seca se apoyaban sobre un armazón de vigas del mismo material y se unían a ésta mediante unas abrazaderas metálicas sujetas con clavos que permitían cierta holgura. Cada tabla disponía de su propia abrazadera. Así, ante la presión de una pisada, por la presencia física de alguien, se producía el roce entre ambos elementos metálicos - abrazadera y clavo- produciendo un estridente chirrido, añadido al sonido que emite cualquier suelo de madera. De algún modo, se asemejaba al sonido emitido por una bandada de pájaros, de ahí la traducción al español de 'suelo de Ruiseñor'. Así, un mínimo ruido en los pasillos de los templos o de los palacios anunciaba irremediablemente la presencia de alguien dentro de sus dominios, incluso el sonido podía transmitir su posición. El sigilo se volvía imposible. En la película 'You Only Live Twice' (1967), lan Flemming encarga a James Bond una misión en algunos palacios japoneses. En una de las escenas se ve a Bond caminando sobre suelos de Nightingale [49].

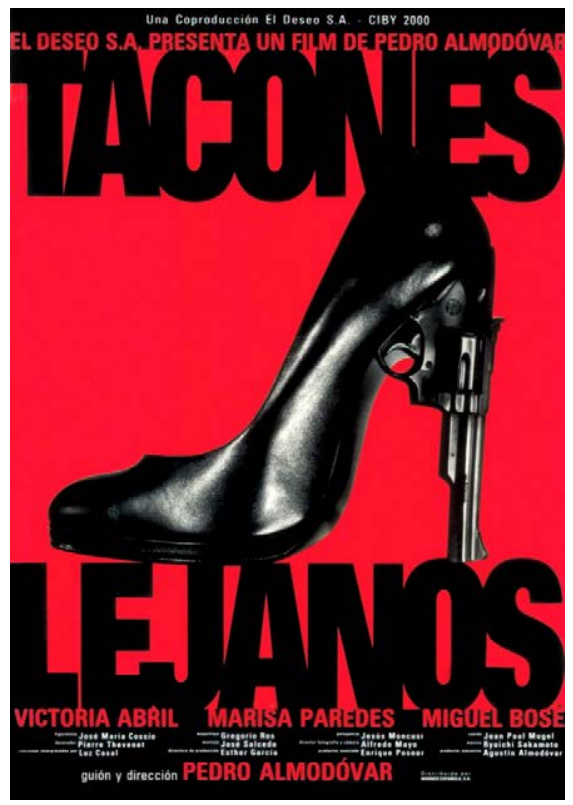

Figura 37.

African dancer Issa Niang performing with touring Ballets Africans company, New York (1959). [Fotografía: @Ralph Morse @LIFE]

Figura 38 Cartel de la película Tacones Lejanos (1991) de Pedro Almodóvar diseñado por Juan Gatti. [Fotografía: @Juan Gatti CEI Deseo Producciones]

Figura 39 Clavos bajo el suelo Nightingale. The secret of the Nightingale Floor. Castillo de Nijô de Kyoto (Japón) (2007) [Fotografía: (C)hris Gladis]

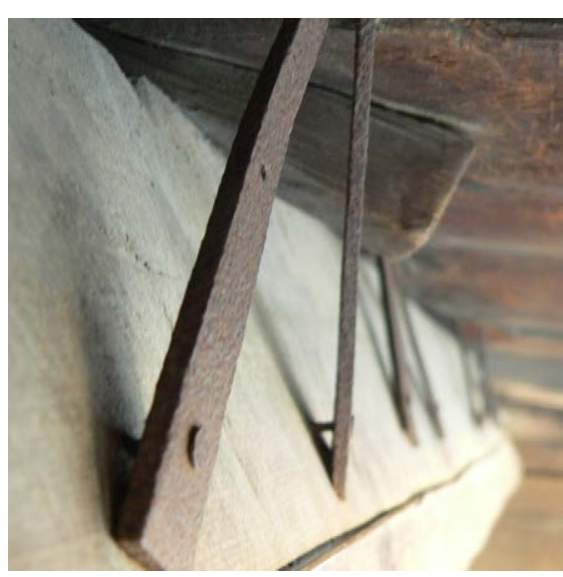



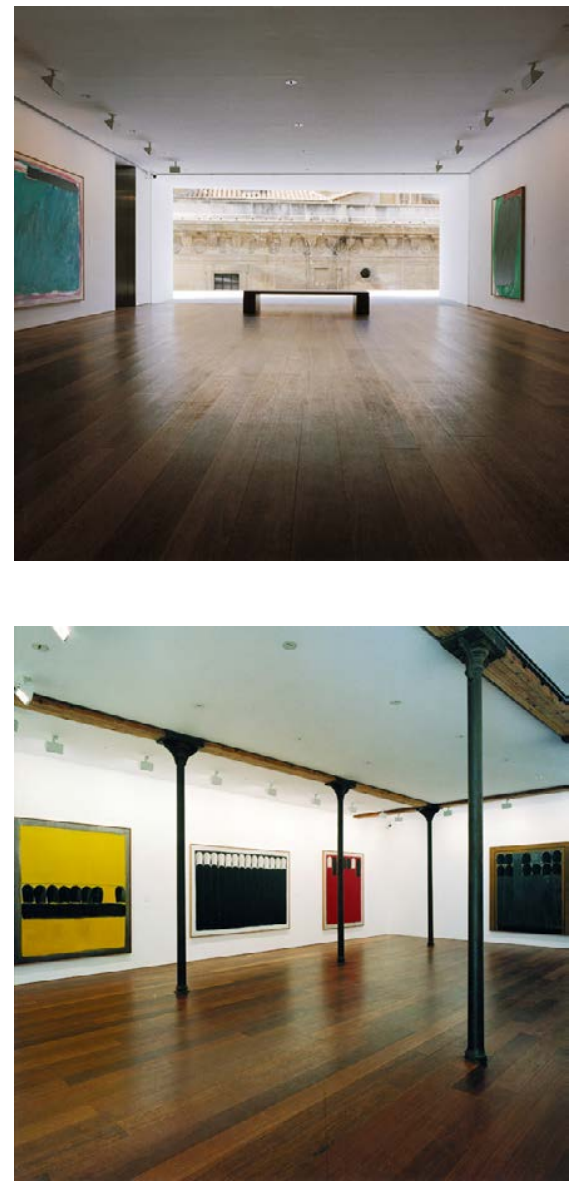

Figura 40. Fotografias interiores del Museo Centro José Guerreo (2000) en Granada. Antonio Jiménez Torrecillas. [Fuente: (C) Estudio Antonio Jiménez Torrecillas]

Figura 41

El bailarín Josué Ullate interpretando Quiebro delante de El Guernica de Picasso en el Centro Nacional Centro de Arte Reina Sofía de Madrid (2014). [Fuente: MNCARS. Museo Nacional Centro de Arte Reina Sofía, Madrid]

[50] Koolhaas, Rem (ed.) y Easterling, Keller. «Floor». En: Elements of architecture. The Venice Biennale. 14th International Architecture Exhibition. Venezia: Marsilio Editori, 2014. p. 53.

[51] Rasmussen, Seen-Eiler. Experiencing Architecture. Cambridge, Massachusetts: MIT Press, 1959.

[52] Pallasmaa, J uhani. Los ojos de la piel. La arquitectura y los sentidos. Puente-Rodríguez, Moisés y Muro, Carles (trads.). Barcelona: Editorial Gustavo Gili, 2014.

Pallasmaa, Juhani. The Eyes of the Skin. Architecture and the Senses. Chichester, UK, 2012.

[53] Rasmussen, Seen-Eiler. Op. Cit.
El cine también se ha aprovechado de los sonidos producidos por el crujir de los pavimentos de madera. En el cine negro (film noir) de la década de 1960, el sonido de los pasos sobre el pavimento - a veces mojado- realzaba el glamour de los personajes o incorporaba el suspense en la escena [50]. Encontramos algunos ejemplos como en la escena de la persecución en 'La mujer pantera' (1942) de Jacques Tourneur (1904-1977) o en 'Sola en la Oscuridad' (Wait until dark) (1967) dirigida por Terence Young y protagonizada por Audrey Hepburn -que interpreta a una mujer ciega.

El último capítulo del libro de Steen-Eiler Rasmussen (1898-1990) La experiencia en la arquitectura (1959) [51] se titula «Hearing Architecture» (Escuchar arquitectura) En ese capítulo, el autor describe diferentes dimensiones de las cualidades acústicas y pone como ejemplo el precepto acústico de los túneles subterráneos de Viena en la película 'El tercer hombre' (1949) de Orson Welles (1915-1985) [52]: «Nuestros oídos reciben el impacto tanto de la longitud del túnel como de su forma cilíndrica» [53].

A veces, con la elección de un pavimento aparentemente ruidoso en un espacio, se busca precisamente lo contrario: el silencio. Así le ocurre al entarimado de madera que cuando cruje, se consigue precisamente una atmósfera callada y silenciosa, ya que cada pisada se convierten en un acontecimiento medido. Así hizo el arquitecto Antonio Jiménez Torrecillas (1962-2015) en el Museo Centro José Guerrero (2000) en Granada (fig. 40). Y es que las tablas de madera que propuso para el suelo, gracias a su crujido — por instalarse con cierta holgura - obligan al visitante del museo a caminar de forma muy sigilosa, limitando sus movimientos. Además, de forma automática, también se disminuye el tono de voz. De ese modo, mejora la experiencia espacial y artística, para disfrutar de los cuadros de José Guerrero (1914-1921). Un recurso parecido fue propuesto por el arquitecto Jorge Lobos en la Iglesia de San Vicente de Paul (1992) en Ancud, Chiloé. En ella proyecta y construye un pavimento a base de conchas marinas. De ese modo, el feligrés que acudiera tarde al culto religioso de la misa sentiría la obligación de quedarse en el fondo; y el que llegó a tiempo para el culto, tenía la obligación de permanecer sentado ya que cada desplazamiento informaría a los demás de las intenciones de cada uno.

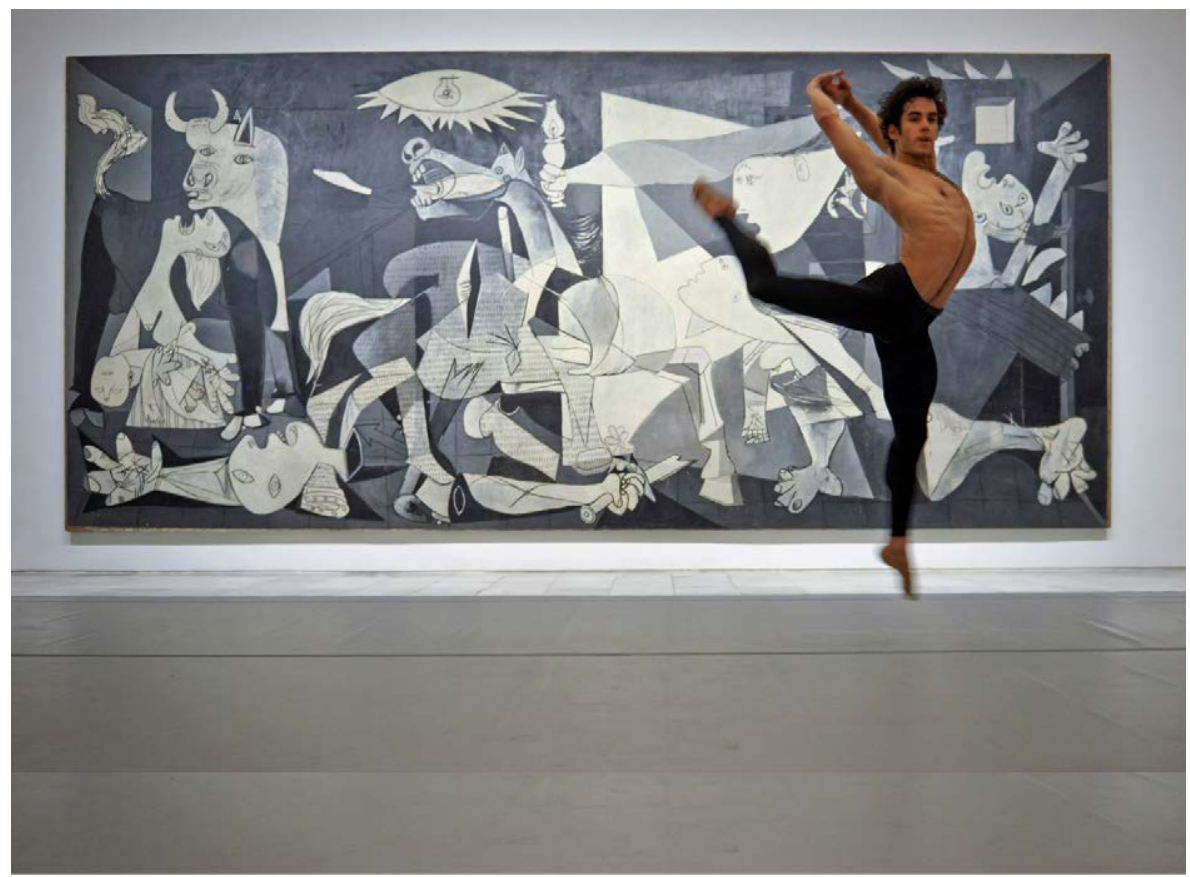




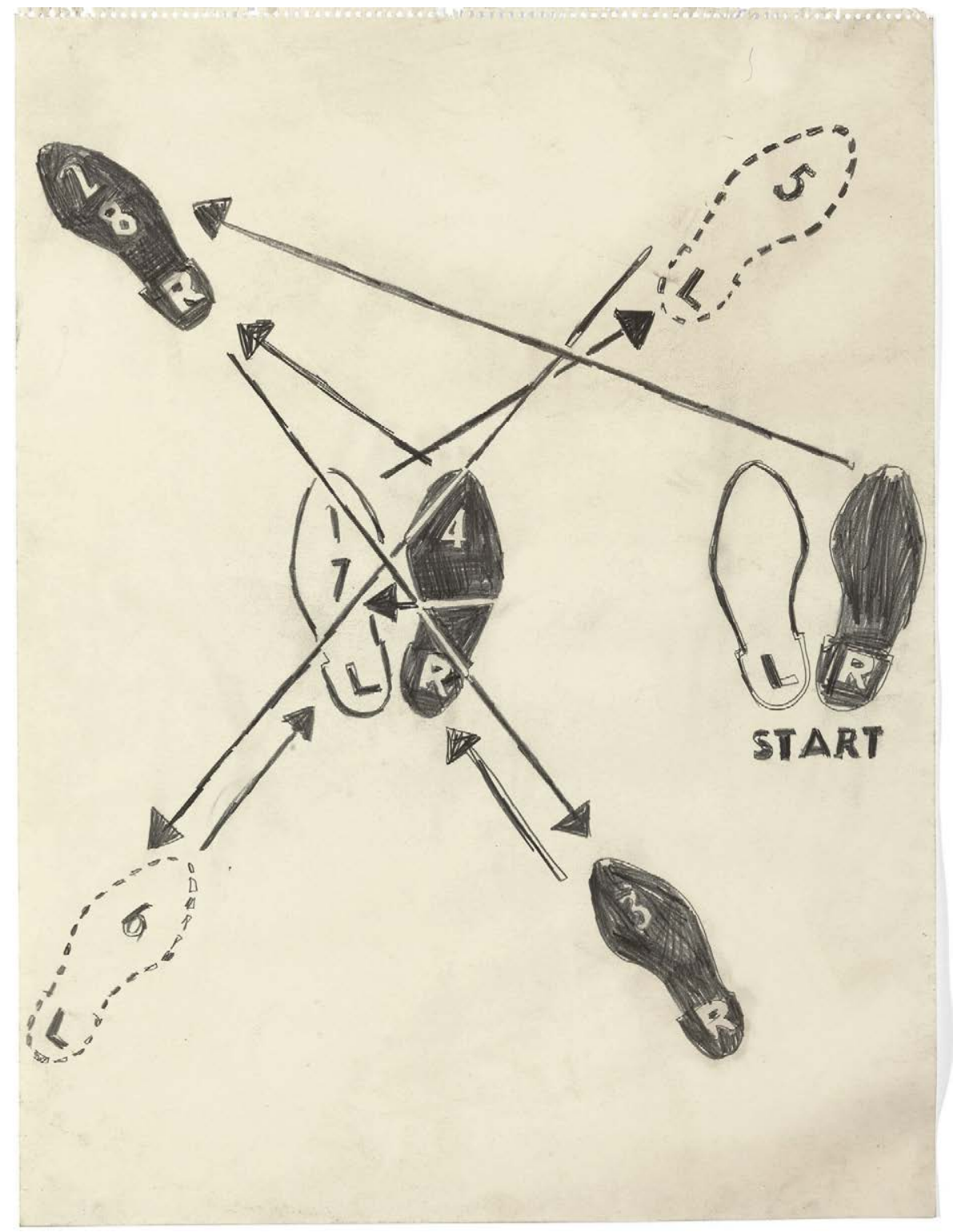

Las pistas de baile fomentan el movimiento exagerado de los cuerpos que, a veces disciplinados, a veces aleatorios, permiten entregar el cuerpo al abandono. Los pies se deslizan por el suelo evitando el rozamiento, por ello las suelas de los zapatos de los bailarines, y el pavimento de las pistas se presentan como superficies brillantes, pulidas y sin una mácula, que eviten cualquier fricción. El pavimento de una pista de baile confía en las habilidades físicas del bailarín, deposita en él el sentido del equilibrio y le convoca a repetir el movimiento una y otra vez (fig. 41). Bien sea en los salones de baile del siglo XIX, como en las pistas de baile modernas, el pavimento recibe la energía y el rozamiento de decenas de pares de pies, que a veces bailan solos, buscando con quien bailar; y a veces bailan acompañados, quizá añorando bailar en soledad.

El moonwalk es un paso de baile que consiste en una serie de pasos deslizando un pie tras otro - sin despegar la suela del suelo- de tal modo que el efecto óptico conseguido es que el bailarín se desplaza hacia delante, cuando su dirección es la contraria. Fue interpretado por Cab Calloway (1907-1994) en la década de 1930, por Bill Bailey (1912-1978) en la década de 1950, siendo definitivamente conocido el paso de Michael Jackson en la década de 1980 [54], quien incluso llegó a patentar un zapato en 1992 para poder inclinarse $45^{\circ}$.

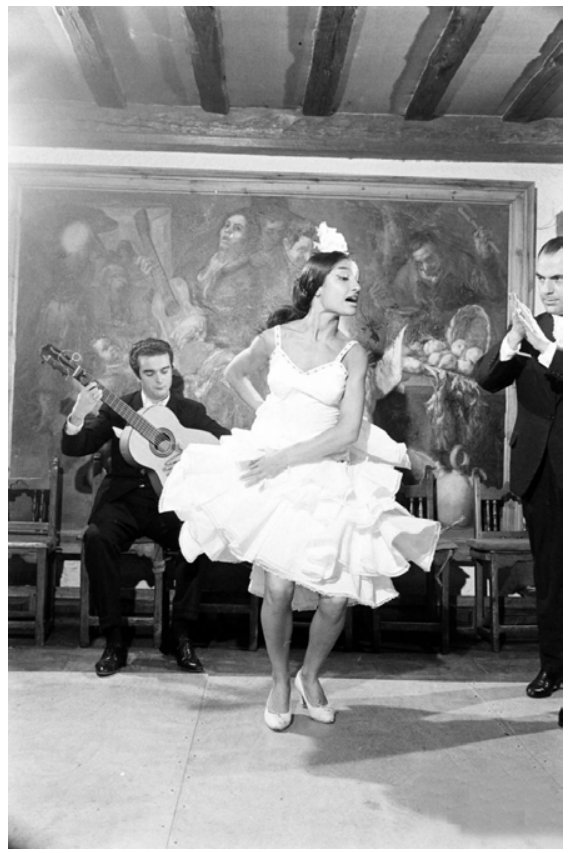

Figura 42

Gitana bailando sobre un ablao' en Madrid (España) (1960). [Fotografía: OLoomis Dean CLIFE]

Figura 43.

Dance Diagram (1962). Andy Warhol. [Fuente: (OThe Andy Warhol Foundation for the Visual Arts, New York]

[54] En marzo de 1983, Michael J ackson actuaba en un especial para la TV 'Motown 25: Yesterday, Today, Forever' que fue emitido en la NBC. Así, ataviado con una chaqueta de lentejuelas negras y un guante de golf blanco, el cantante interpretaba su éxito 'BillieJ ean' y lo hacía con el 'Moonwalk'. 


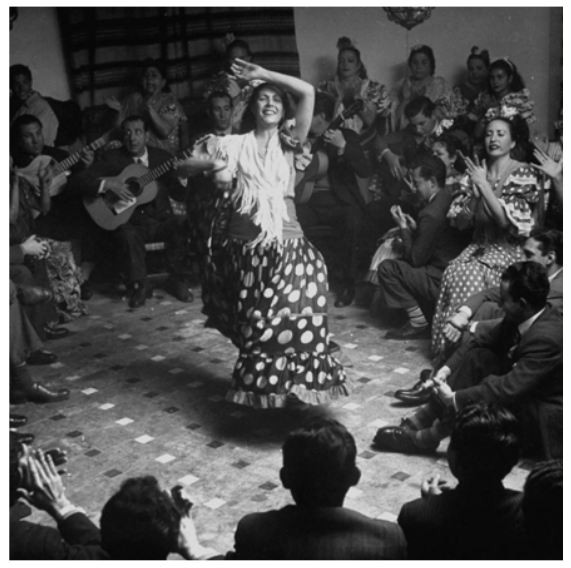

Figura 44. Bailaora flamenca bailando en Granada (España) (1949). [Fotografía: CDmitri Kessel CLIFE]

Figura 45

Dance Diagram (1962). Andy

Warhol. [Fuente: (TThe Andy

Warhol Foundation for the

Visual Arts, New York]
En el baile flamenco o en el claqué, el pavimento se convierte en un instrumento musical. El taconeo o el zapateado sobre el tablao' flamenco — una tarima construida con 'tablas' de madera a modo de escenario- o sobre el suelo de cerámica de un patio andaluz, convierte al bailarín o a la bailarina en un intermediario que hace posible que, con el movimiento de su cuerpo y con el sonido que emiten sus pies, se pueda manifestar en solitario, sin compañía y sin música.

El flamenco nace de la queja - de un quejio', dicen en Sevilla- y de la rebeldía; pero también del dolor y de la injusticia. Cuando el bailaor' taconea, cuando golpea con fuerza sus zapatos sobre el pavimento lo que transmite no es otra cosa que una indignación sin palabras (fig. 33, fig. 35, fig. 42 y fig. 44). Es un berrinche intencionado, donde se grita y patea sobre el suelo. Es el modo que tiene de manifestarse. Es la forma que tiene de expresarse como puede, porque no siempre se escucha a los oprimidos. Como decía Josep Pla (18971981), el único privilegio de los pobres es la escucha. Y quizá sea lo único que se espera de ellos. Por eso el flamenco nace como respuesta al silencio con el que se intenta condenar al humilde.

En 1983, la artista flamenca Remedios Amaya (1962-) representó a España en el Festival de la Canción de Eurovisión que ese año se celebraba en Múnich (Alemania). Interpretó la canción '¿Quién maneja mi barca?' y lo hizo descalza. Esa circunstancia llamó la atención del realizador de TV del festival ya que filmó varios primeros planos de sus pies descalzos. La candidatura española no obtuvo ni un solo punto de ninguno de los países participantes, quedando en última posición del certamen, empatando con Turquía. Pero lo único que se recuerda de aquel fracaso fueron los pies descalzos sobre aquel escenario.

En las tribus amazónicas, los hombres bailan golpeando con un palo en el suelo, a la vez que hacen con los pies. Es el baile de yadiko, que más que una danza, es una ceremonia para intentar resolver problemas que preocupan en la comunidad. $\mathrm{O}$ algunas danzas y bailes africanos que lo que transmiten es alegría y celebración como la danza Ambas-i-bay de Camerún, el Coupé-Décalé de Costa de Marfil o el Gombey de Senegal que celebra la cosecha. Como apuntaba el senegalés Léopold Sédar Senghor (1906-2001): «...somos los hombres de la danza, cuyos pies / retoman vigor golpeando el suelo duro...»

La primera instalación individual [55] de Andy Warhol (1928-1987) en New York se celebró en la Stable Gallery el 6 de noviembre de 1962, donde se presentó 'Dance Diagram' (1962) (fig. 43 y fig. 45), una obra formada por siete diagramas con instrucciones para el baile (fox trot, tango,...) basados en los libros Fox Trot

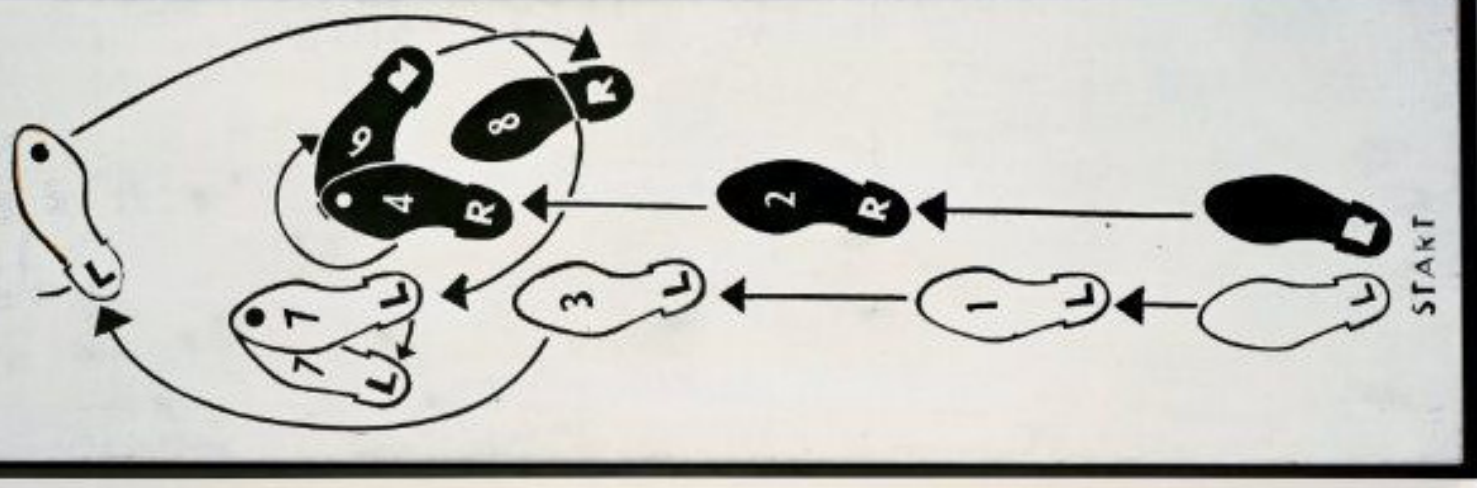




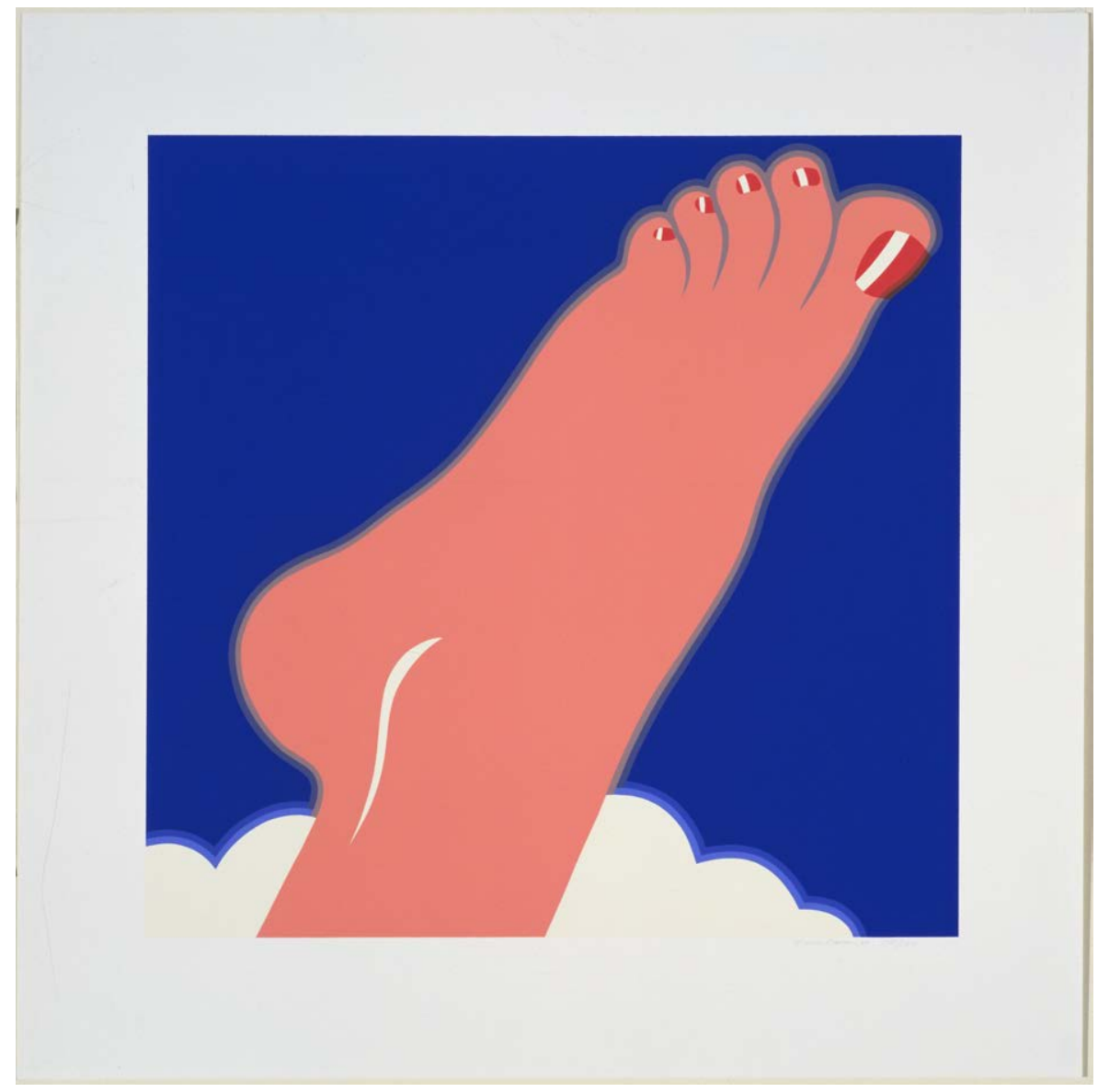

made easy, Lindy Made Easy (Charleston) o The Easy Way to Good Dancing (1956) de Dance Guild [56]. El material —de grandes dimensiones—se instaló en el suelo de la galería, casi ocupando la superficie en su totalidad. Los diagramas, formados por siluetas de zapatos —las negras representaban el pie derecho, marcado con una $\mathrm{R}$, y las blancas el pie izquierdo, marcado con una 'L'- y unas flechas con instrucciones e indicación del inicio y del orden a seguir, animaban al público a ejecutar el paso de baile de la receta (del prospecto). Al fin y al cabo "la 'estética relacional' es un arte que toma como horizonte teórico el ámbito de la interacción humana y su contexto social, en lugar de la afirmación de un espacio simbólico independiente y privado» [57]. Es decir, el arte es un estado de encuentro entre los cuerpos y las atmósferas. En esta obra de Warhol, los diagramas se enredan con los pies de los espectadores.

Andy Warhol en su obra 'Dance Diagram' (1962) traslada a la obra de arte de un plano óptico vertical al plano corpóreo horizontal. El pavimento se convierte en un dictador del placer. De este modo, el suelo ofrece instrucciones al cuerpo que no necesitan ser traducidas con palabras. No se trata de saber algo, sino de saber cómo [58]. Esto se representa bien en la fotografía anónima -probablemente de finales del siglo XIX — titulada: 'A nurse steadying a woman by holding her right arm, while the woman attempts to walk along a mat marked with footprints' (fig. 46).

Y es que sobre el pavimento trazado de líneas, como veremos en el Capítulo 8: «El pavimento como soporte narrativo. El suelo parlante», se esconden algunos códigos, algunas reglas, y algunas normas que, una vez conocidas, ofrecen una información que los pies pueden seguir.

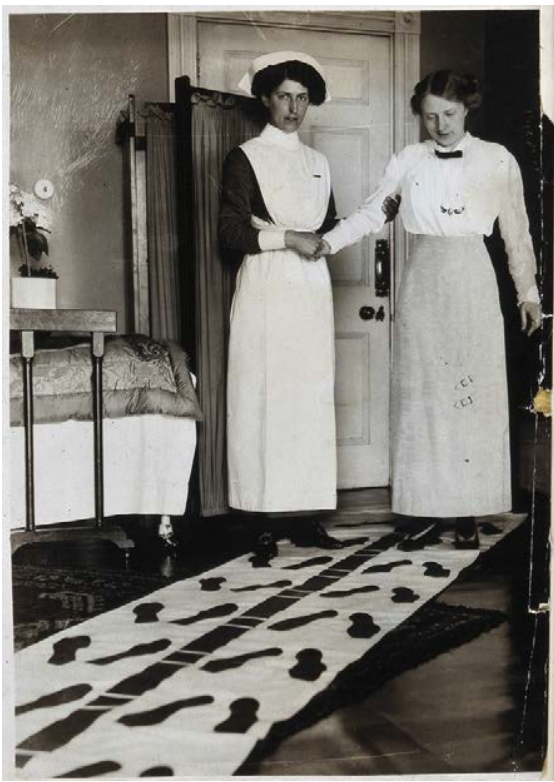

Figura 46 A nurse steadying a woman by holding her right arm, while the woman attempts to walk along a mat marked with footprints (c1900). [Fotografía: CS/N CWellcome Collection]

Figura 47.

Seascape (Foot) from the portfolio Edition 68 (1968). tom Wesselmann. [Fuente: (CMoMA Museo de Arte Moderno de New York. 1190.1969]

[55] La primera exposición individual de Andy Warhol fue en la Geleria Ferusel, el 9 de julio de 1962.

[56] Guild, Dance. Fox trot made easy. New York: Dance Guild of America Pub. Corp, 1956.

Guild, Dance. The Easy Way to Good Dancing. New York: Dance Guild of America Pub. Corp, 1956.

Guild, Dance. Lindy Made Easy (charleston). New York: Dance Guild of America Pub. Corp, 1956.

[57] Bourriaud, Nicolás. Estética relacional / Esthétique relationnelle. Buenos Aires: Editorial Adriana Hidalgo, 2006.

[58] Koolhaas, Rem (ed.) y Easterling, Keller. «Floor». En: Elements of architecture. The Venice Biennale. 14th International Architecture Exhibition. Venezia: Marsilio Editori, 2014. p. 34. 
Pavimentos: huellas fenomenológicas, registros arqueológicosy planos de referencia

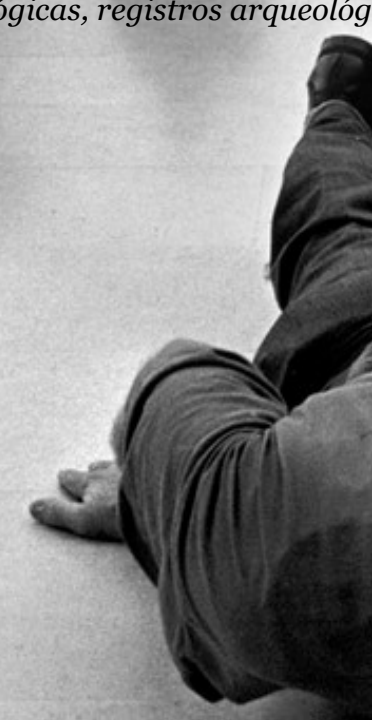




\section{CAPÍTULO 5}

\section{El suelo habitado por el cuerpo Arquitectura de contacto}

\section{Introducción}

El suelo, como arquitectura de contacto, es también, a veces, un sitio para el cuerpo. La querencia natural por el orden general de las cosas, obliga a los objetos a permanecer en su sitio. Cuando algo se precipita por el suelo —si es sólidos - o si se derrama — si es líquido - es una señal de desorden e inestabilidad del conjunto. El ajuar doméstico esparcido por el suelo es un signo inequívocos de un cierto 'chaos'. Y contra ese caos, el 'estilo Shaker' que, más allá del minimalismo esencialista que se le presume, propone liberar al suelo de objetos prescindibles, estableciendo un plano continuo, limpio y reconocible. La cultura japonesa también combate el desorden, y propone mantener el pavimento del suelo minuciosamente limpio y ordenado [1].

Si los objetos no deberían estar en el suelo, todavía menos deberían estar los cuerpos de los hombres tumbados sobre el pavimento en lugares inesperados. Pocas decisiones tan sencillas como tumbarse sobre el suelo en un lugar público resultan tan poderosas. Un cuerpo sobre un suelo resulta inquietante, pero si además se presenta inmóvil, puede llegar a causar cierto impacto. También resultan inquietantes los cuerpos que yacen sobre el suelo en lugares donde no se esté produciendo algún ritual o si el sujeto no lleva una indumentaria asociada. Esto se exagera cuando en un ámbito acotado esta situación —de encontrarse cuerpos tumbados sobre el pavimento- se produce mientras el resto de personas están sentados o erguidos.

Sin embargo, los cuerpos tumbados, inclinados o postrados sobre el pavimento en las catedrales, en las iglesias o en las mezquitas resultan emocionantes, donde la sumisión se percibe como acto de humildad [2]. Esto se produce, por
Figura 0. Página anterior Penitent leaning front on the Virgin of Fatima, Portugal (1950). [Fotografía: @Cristina Garcia-Rodero @Magnum Photos. PAR298209]
[1] Koolhaas, Rem (ed.) y Easterling, Keller. «Floor». En: Elements of architecture. The Venice Biennale. 14th International Architecture Exhibition. Venezia: Marsilio Editori, 2014. pp. 56-57.

[2] Ibíd. p. 56. 


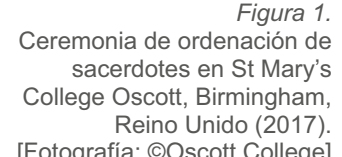

[Fotografía: @Oscott College]

Figura 2. El Papa Francisco (Jorge María
Bergoglio) reza postrado sobre Bergoglio) reza postrado sobre
el suelo en la Basilica de San Pedro durante el Viernes Santo (2013). [Fotografía: @Max Rossi @Reuters]
Figura $3 a$ y $3 b$

Mexico (1934). [Fotografia:

OHenri Cartier-Bresson

@Magnum Photos. PAR17866.

PAR17879]
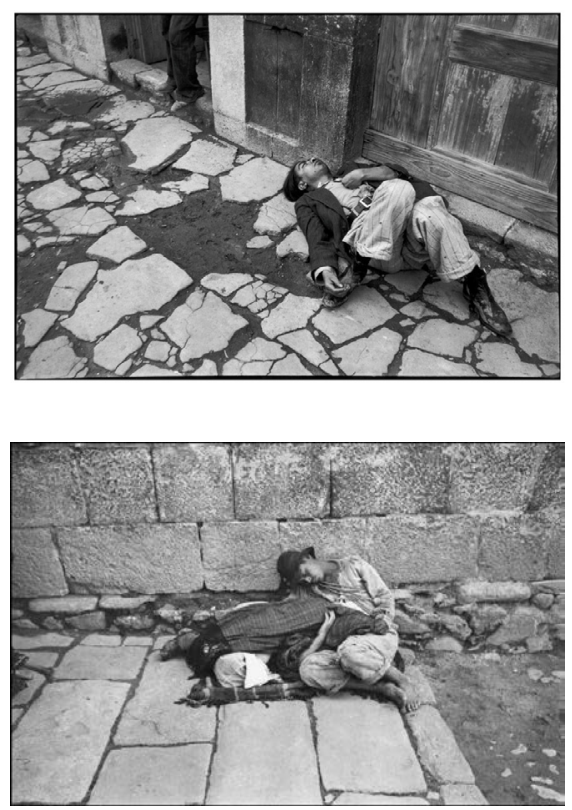
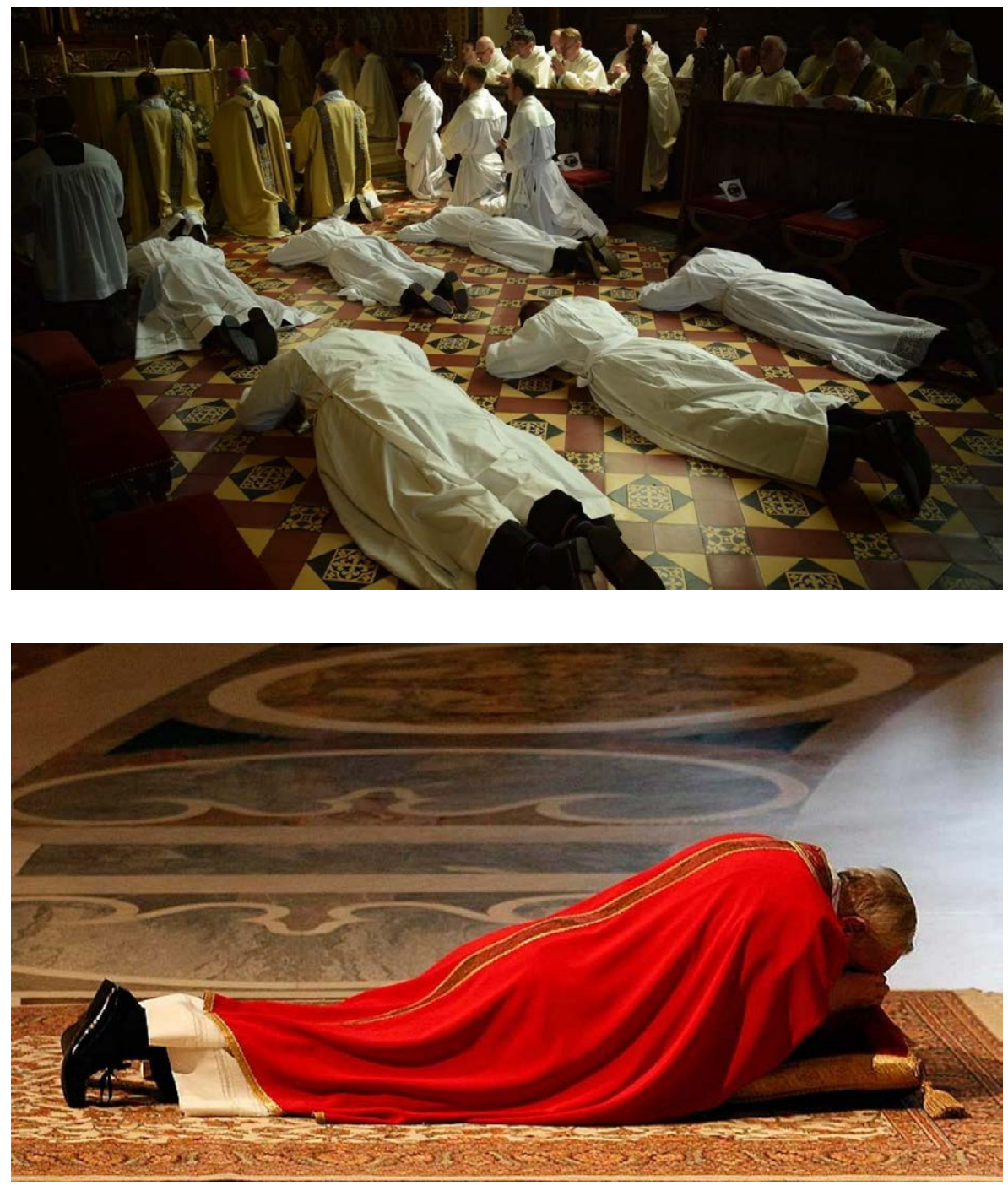

ejemplo, en las ceremonias de ordenación de sacerdotes. También algunos obispos, o incluso el papa, se postran tumbado sobre el suelo para rezar cada Viernes Santo.

Los mendigos tumbados en la calle provocan desazón porque el suelo sin techo en el espacio público es el único hogar posible para ellos en ese momento. A los pobres del mundo, se les podrá arrebatar un techo, pero nadie les podrá quitar un suelo. Los 'sin techo' encuentran en los pavimentos de las ciudades un hogar temporal o eterno. Si bien se ha aceptado el neologismo 'sintechismo', nunca se utilizará un término parecido para los 'sin suelo', porque afortunadamente, todos tenemos un suelo: La Tierra.

La palabra 'humillar' viene del verbo latín humiliare, y quiere decir 'hacer que uno se postre o se arrastre por el suelo' (en latín humus), obligarle a reconocer su bajeza ante otro o arrastrarle por el suelo, postrarle, rebajando totalmente su dignidad' [3]. En inglés la expresión 'to be floored' se traduce como 'ser derribado', 'derrotado' o 'pisoteado' en sentido literal o figurativo. Es decir, es una forma metafórica de expresar la victoria sobre el vencido.

En muchas obras literarias y en el cine, la escena del suelo cubierto de sangre es un recurso que se repite de forma recurrente. El mensaje es eficaz: es un presagio de un dolor inminente o de una muerte reciente. Pero también es una 
escena que la literatura ha descrito en muchas ocasiones. Por ejemplo, en La Odisea de Homero es recurrente la escena donde se describen los suelos sobre los que corre la sangre: "Y eran horribles los gemidos que se levantaban cuando las cabezas de los pretendientes golpeaban el suelo, y éste humeaba todo con sangres» [4]. O el cuento de Agatha Christie (1890-1976) The Bloodstained Pavement [5] también insiste en ello, incluso desde el propio título.

Los cuerpos tumbados sobre la toalla en el lecho de la arena de la playa, son la demostración de la libertad del hombre por elegir su posición y su postura en el espacio público. Una toalla en la arena es un pavimento efímero. Pero también la toalla se convierte en un recinto de propiedad temporal, en un lugar con unas normas y con un perímetro acotado. Así, cada una de las toallas, con sus tamaños, con sus texturas y con sus colores diferentes, participan como una unidad, en la construcción de un mosaico horizontal sobre la arena y que cada día será distinto, casi en cada momento, ya que su orientación cambia a lo largo de la jornada. Los cuerpos buscan ávidos recibir el sol en toda su plenitud, y las toallas, casi como las agujas de un reloj, van girando para alinearse con el sol.

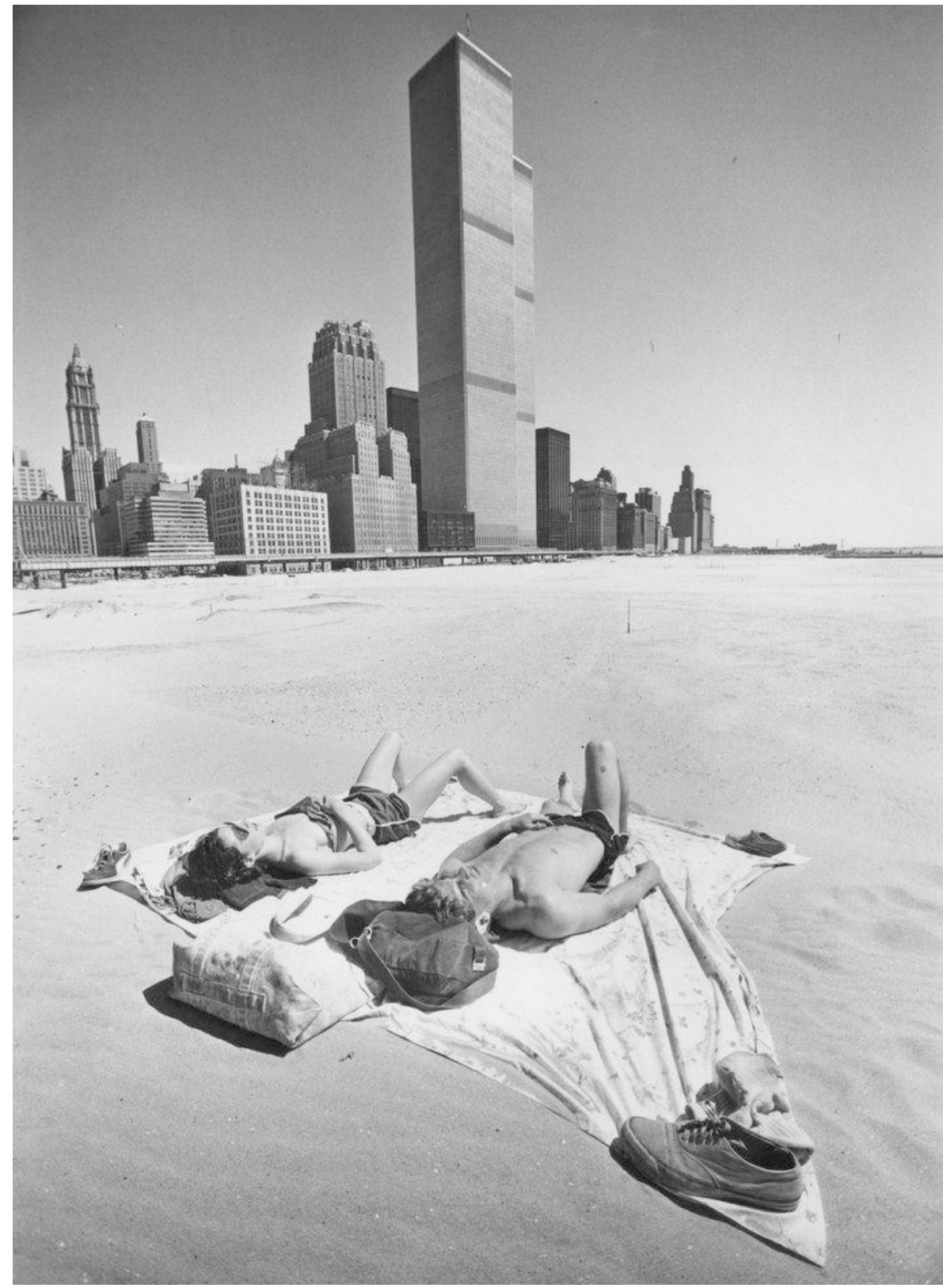

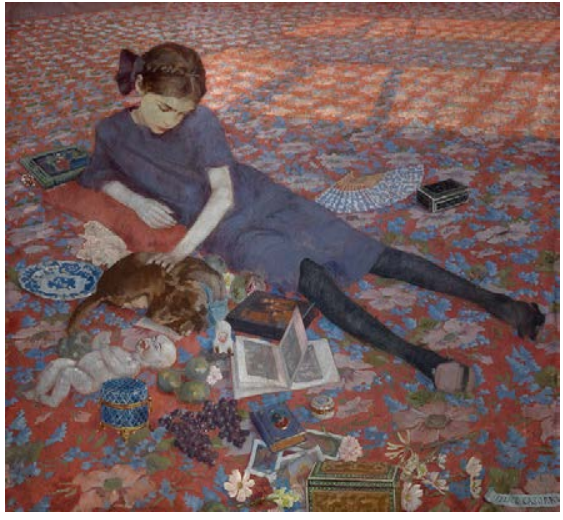

Figura 4. Young girl on a Red Carpet (1912). Felice Casorati. [Fuente: CMSK Museum voor Schone Kunsten Gent. 1915-D]

Figura 5

Battery Park City (1977)

[Fotografía: CFred Conrad]
[3] Corominas-Vigneaux, J oan y PascualRodríguez, J osé-Antonio. Diccionario crítico etimológico Castellano e Hispánico. Barcelona: Editorial Gredos, 2000.

[4] Homero. «Canto XXII». La Odisea. Barcelona: Espasa libros, 2010.

[5] Christie, Agatha. The Thirteen Problems (Miss Marple). New York: HarperCollins, 2008. 


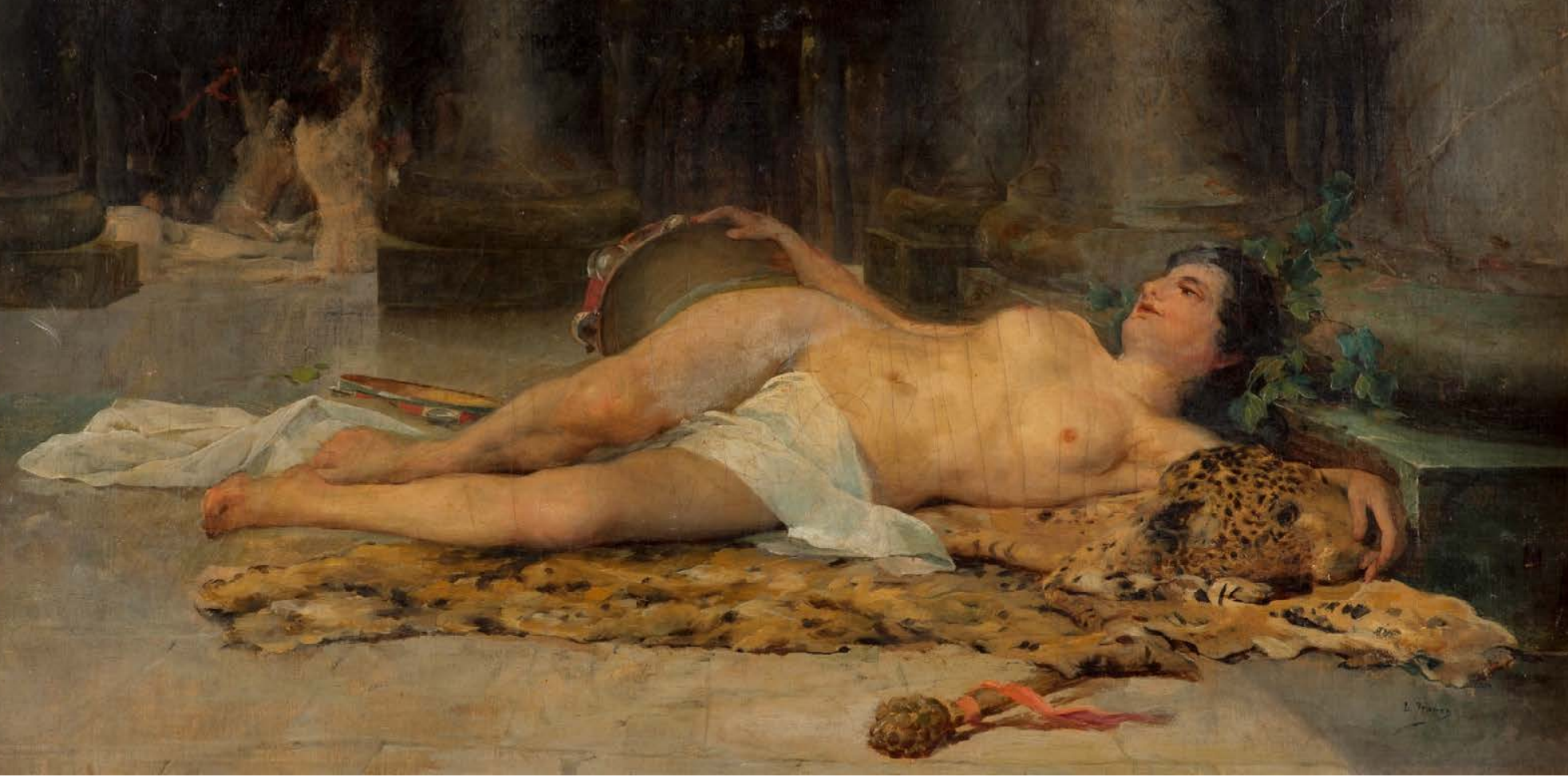

Figura 6.

Bacante desnuda (c1880). Luis

Franco Salinas. [Fuente:

CMuseo Nacional del Prado de

Madrid. P006534]
También el suelo es la superficie o el recinto donde satisfacer los instintos más primarios del placer. El pavimento es un campo de fuerza libidinosa [6]. La literatura, la pintura, la fotografía y el cine nos han mostrado escenas donde el suelo se ha convertido en el lecho predilecto de unos amantes ante la impaciencia de encontrar otros acomodos más mullidos. O aunque existieran, el suelo ha sido tratado como un plano elemental ante las urgencias que exigen los deseos más íntimos.

\section{Horror vacui. El pavimento rozado por los artistas}

'Il tuffatore' se encuentra en un fresco de la tumba etrusca del nadador (475 a.C.), situada en una necrópolis al sur de la ciudad griega de Paestum, en el sur de Italia. La bella imagen representa a un joven que, disfrutando de un flamante salto desde un suelo seguro, se dirige en el aire hacia las ignotas aguas del mar abierto.

La imagen, como metáfora visual, anima a la investigación de lo desconocido, al reto y al riesgo. $Y$ se enfrenta directamente contra el miedo, como el gran sentimiento paralizante.

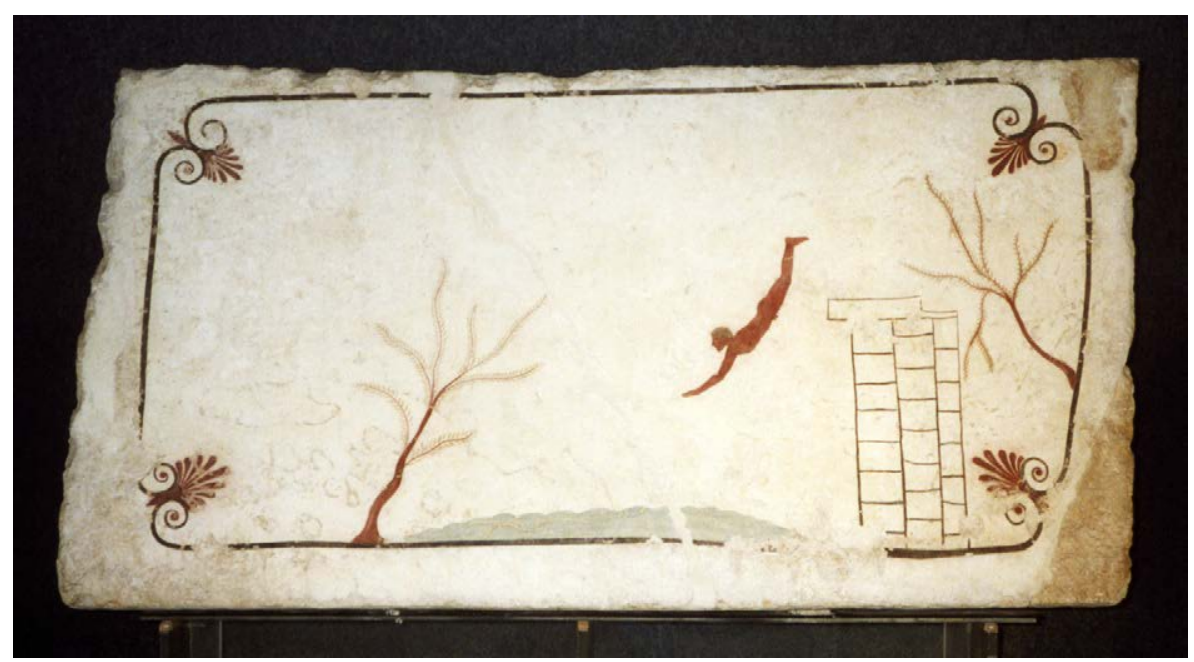




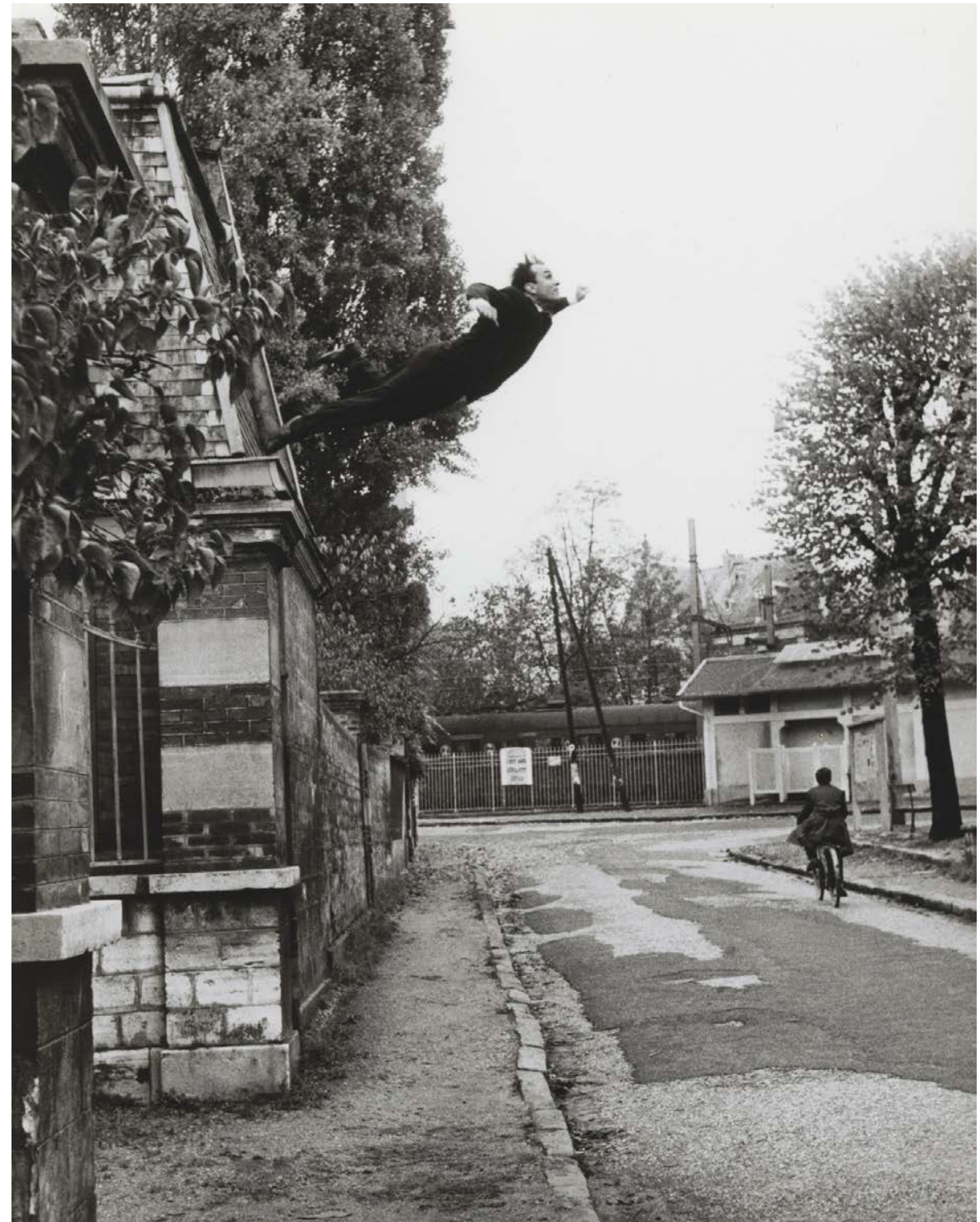

El miedo al vacío ha sido un tema recurrente a lo largo de la historia, tanto desde un punto de vista metafórico como físico. Algunas personas que no encuentran otra salida, se precipitan desde lo alto entregándose en cuerpo y alma al suelo pavimentado y duro, como un último y definitivo acto heroico. $Y$ el suelo los recibe en silencio, como siempre. $Y$ a pesar de todo, incluso en ese estado límite, el hombre es más grande que todo el suelo de la Tierra: porque en esa situación última, el hombre sabe que muere y el suelo no sabe que lo mata [7].

En 1960, y en la Rue Gentil-Bernard de Fontenay-aux-Roses, una estrecha calle de las afueras de París, el fotógrafo Harry Shunk (1924-2006) retrató al artista Yves Klein (1928-1962) arrojándose —de forma figurada y aparente— al vacío. La imagen formaba parte del proyecto que el artista llamó 'El hombre en el espacio. El pintor del espacio se arroja al vacío', y sin querer la fotografía se convirtió en un icono del siglo XX (fig. 8). La elección del encuadre de la imagen permitía que aparecieran tanto la ventana como origen del salto, así como el pavimento entendido como ineludible destino del cuerpo. Pero si se analiza con detenimiento, la figura del pintor se encuentra en un punto de suspenso que permite entender por igual que se trata de un salto ascensional como de una caída. Yves Klein, que fue un artista postmoderno, proyectó el arte en lo invisi-
Figura 8.

Leap into the Void / Salto al vacío (1960) [Fotografía: CHarry Shunk y János Kender CMoMA CMuseo de Arte Moderno de New York (C)Artists Rights Society (ARS) New York / ADAGP, París @J. Paul Getty Trust. The Getty Research Institute, Los Ángeles. 1015.2013.1]
[6] Koolhaas, Rem (ed.) y Easterling, Keller. «Floor». En: Elements of architecture. The Venice Biennale. 14th International Architecture Exhibition. Venezia: Marsilio Editori, 2014. pp. 58-59.

[7] «Pensaba entonces que el ser humano era algo sobrenatural: que un náufrago ahogándose en el mar es más grande que le mar, porque el náufrago sabe que se mure y el mar no sabe que lo mata».

Gala-Velasco, Antonio. Los papeles de agua. Barce lona: Editorial Planeta, 2008.

Ramiro de Maeztu: «Vosotros no sabéis por qué me matáis, pero yo sí sé por lo que muero: ipara que vuestros hijos sean mejores que vosotros!». 


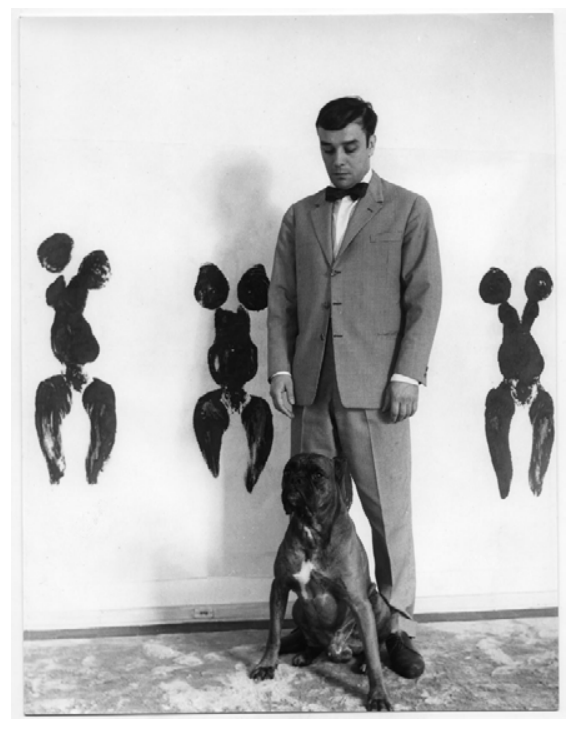

Figura 9. Retrato de Yves Klein frente a una Anthropometry con su perro Corporal (ANT 82) (1960). 14, rue CampagnePremière, París. [Fotografia: CMartha Rocher]

Figura 10. Untitled Anthropometry (ANT 74) (c1960). Yves Klein. [Fuente: (T) The Estate of Yves Klein. ADAGP, París]

[8] 'Anthropométries', fue el término con el que bautizó el crítico Pierre Restany, amigo de Klein, a esta técnica: «¡Estas son las antroopmetrías de la Época Azul!».

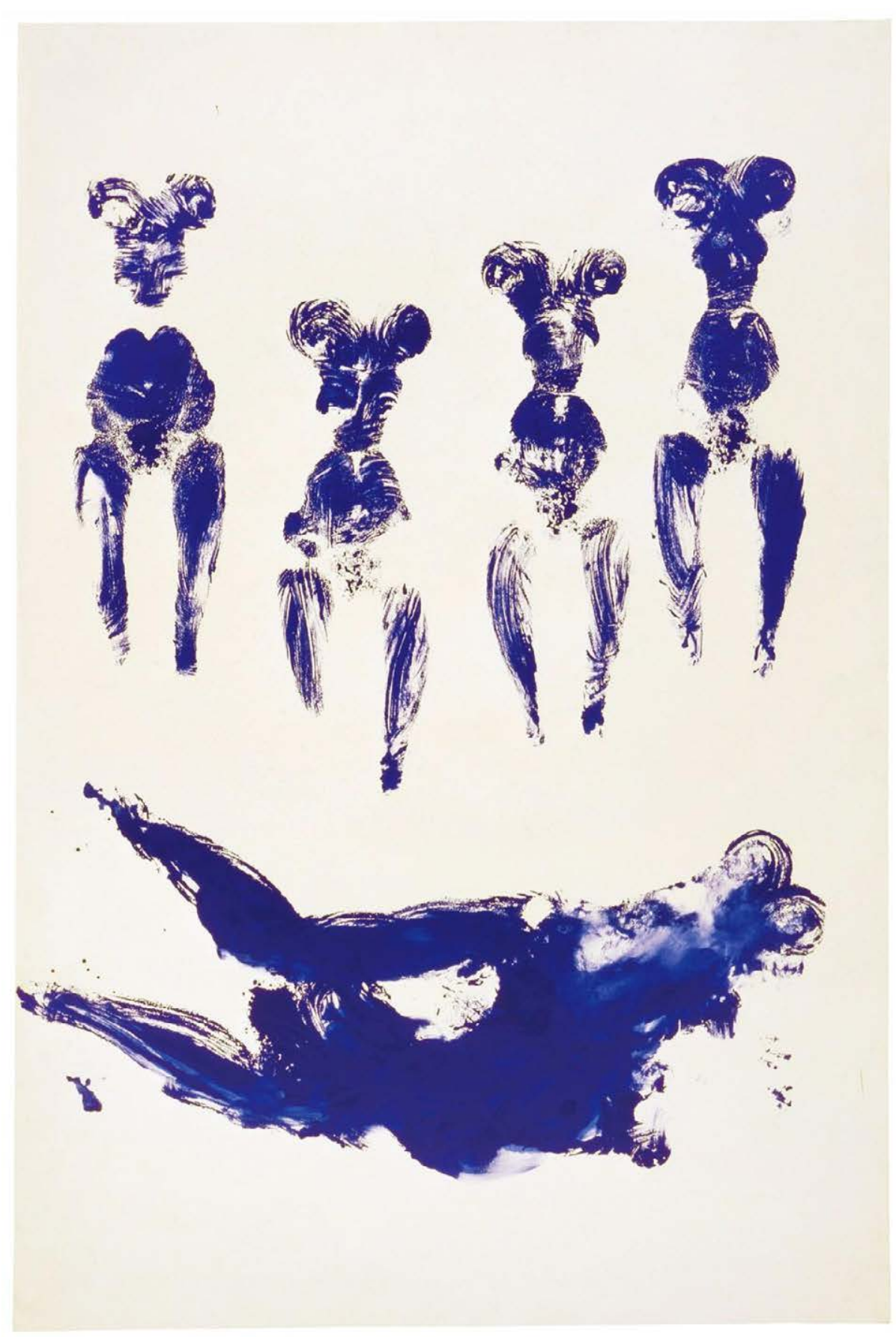

ble, compuso la 'Sinfonía Monótona Silencio' (Symphonie Monoton Silence) e imaginó una 'arquitectura del aire'. El interés por el judo de Yves Klein, ya que había sido maestro de este deporte, le influyó en su modo de interpretar el mundo, ya que los cuerpos, cuando caen sobre el tatami, siempre dejan huellas visibles.

Entre 1958 y 1960 desarrolló la idea de usar cuerpos desnudos como 'pinceles vivos' (pinceaux vivants) que dejaban huellas sobre lienzos situados en el suelo. Las 'Antropometrías' (Anthropométries) [8], entendidas como acciones de contacto entre el cuerpo humano desnudo y el suelo, le permitían a Klein separarse de su obra. El primer experimento lo realizó el 27 de junio de 1958, en la casa de Robert Godet (1866-1950), cuando hizo rodar a una modelo desnuda embadurnada de pintura de color azul sobre un papel extendido sobre el suelo. Así, las formas del cuerpo femenino se habían reducido a lo esencial del tronco 


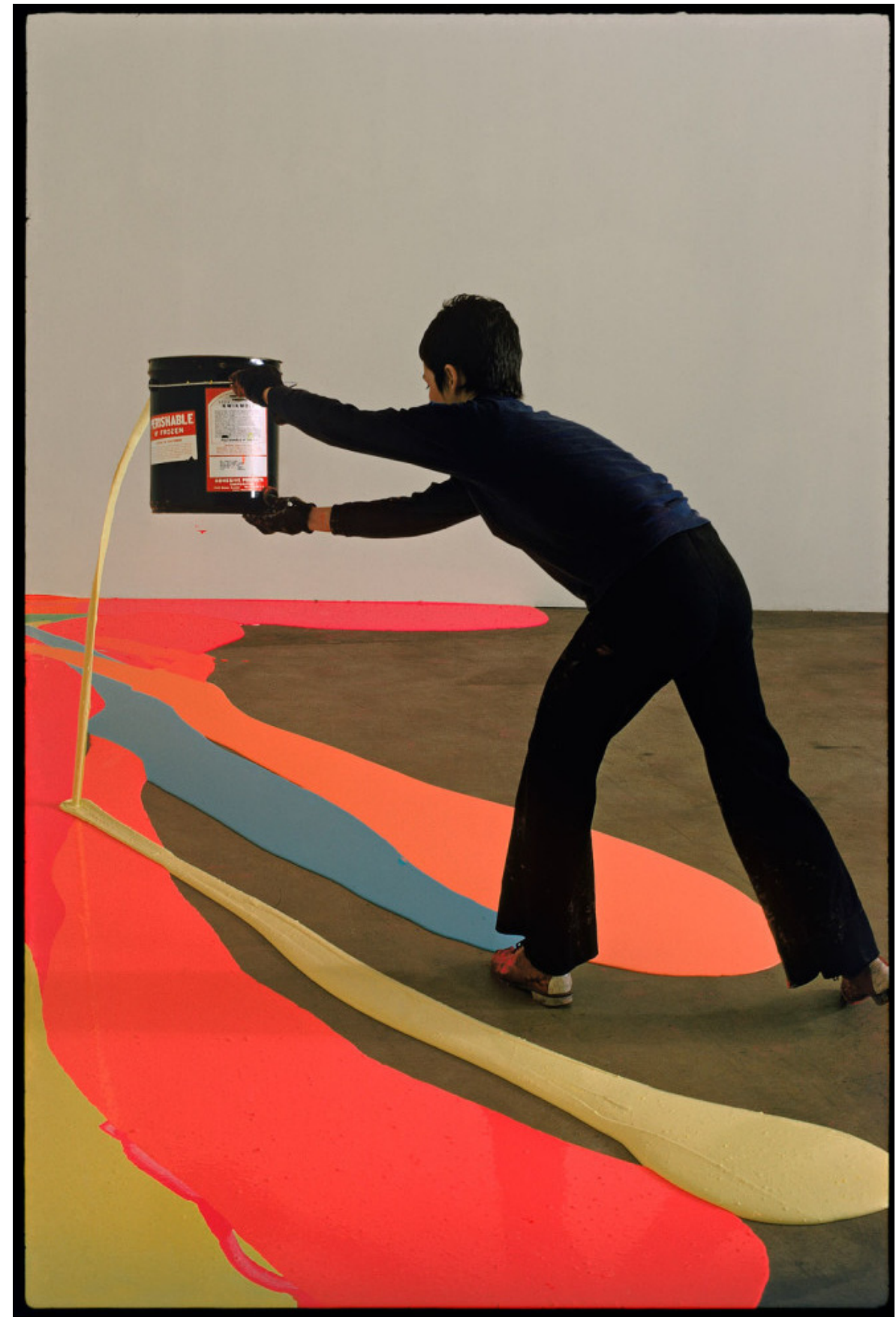

del talle, como un ideograma antropométrico. Después de aquel experimento, llegaron unas cincuenta antropometrías sobre papel y unas treinta sobre seda. Así, cada una de ellas era el resultado del contacto entre el cuerpo de las mujeres y el plano del suelo, encontrando unos ejemplos más estáticos y otros más dinámicos, a veces sobre el fondo blanco y otras veces el roce del cuerpo - esta vez pintado de blanco- se producía sobre un fondo oscuro, produciendo huellas estáticas sencillas y rastros dinámicos de cuerpos en movimiento sobre el suelo.

Durante la segunda mitad del siglo XX se introduce un factor hasta entonces inédito: la fuerza de la gravedad hacia el suelo incorporada en el proceso creativo artístico. Estas obras de Yves Klein engarzan con algunas obras de Jackson Pollock (1912-1956), como los drippings que consistían en dejar caer pintura muy diluida sobre un lienzo situado también en horizontal precisamente sobre el

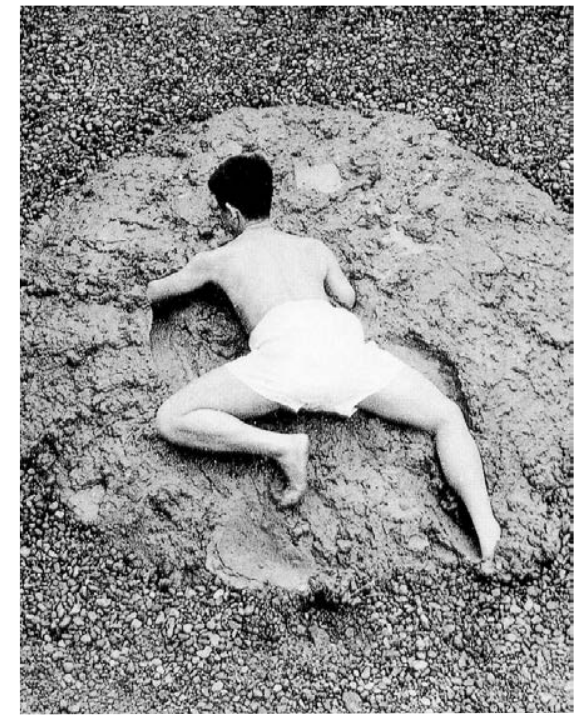

Figura 11

Luchar contra el barro (19 de octubre de 1955). Shiraga Kazuo. [Fotografía: @ Japon des Avantgardes 1910-1970 (c) Centre Pompidou, París]

Figura 12.

Latex Floor Painting (1970) Lynda Benglis. [Fotografía: CHenry Groskinsky @LIFE] 

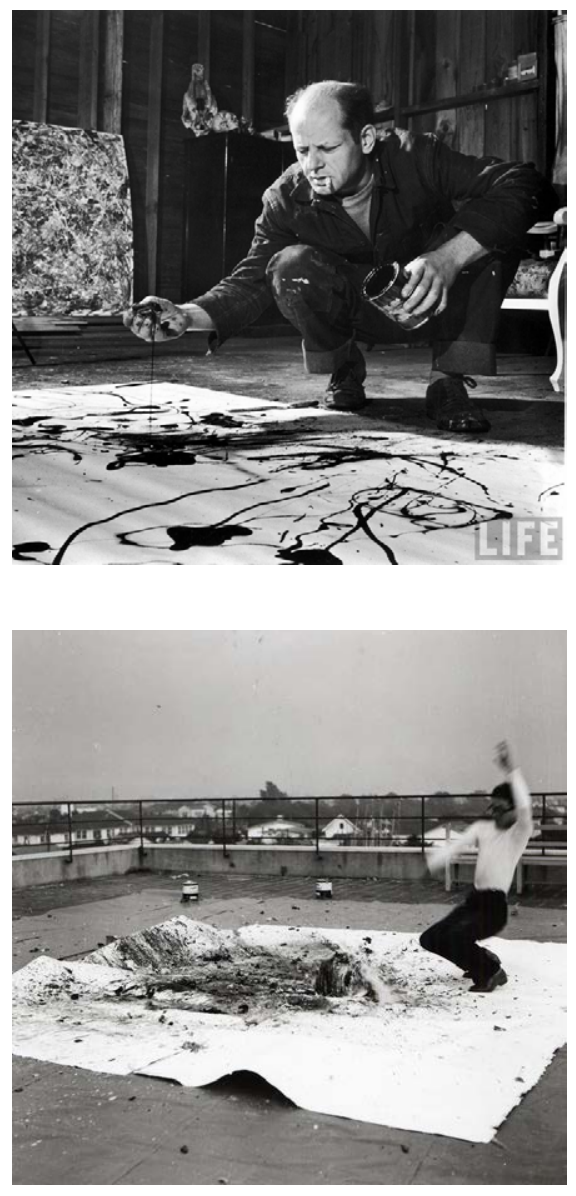

Figura 13.

Jackson Pollock trabajando en

su estudio (1949). [Fotografía:

(CMartha Holmes @LIFE]

Figura 14 .

Shozo Shimamoto (1956).

[Fotografía: @Shozo

Shimamoto @Gutai Art

Asscoation, and Museum of

Osaka University]

[9] Michelson, Annette (ed.). Andy Warhol. October files, 2. Cambridge, Massachusetts: MIT Press, 2001.

[10] Ramírez-Domínguez, J uan-Antonio. «Pavimento, suelo, tierra (de promisión)». En: Fernández-Polanco, Aurora (ed.). Cuerpo y mirada, huella del siglo XX. Madrid: Museo Nacional Centro de Arte Reina Sofía, 2007. pp. 65-87.

[11] Selvamony, Nirmal. «Kalam as Heterotopia». En: Muthukumaraswamy, M.D. Folklore as Discourse. Chennai, India: National Folklore Support Center, 2006.

[12] Ramírez-Domínguez, Juan-Antonio. Op. Cit.

[13] Koolhaas, Rem (ed.) y Easterling, Keller.

«Floor». En: Elements of architecture. The Venice Biennale. 14th International Architecture Exhibition. Venezia: Marsilio Editori, 2014. p. 58. suelo [9]. Algo que se mostraba muy bien en las conocidas fotografías publicadas en la revista LIFE. En 1947, Pollock decía:

«Mi pintura no procede del caballete, raramente estiro el lienzo antes de pintar. Prefiero clavar el lienzo sin estirar sobre la pared dura o sobre el suelo. Necesito la resistencia de una superficie dura. Sobre el suelo me siento más cómodo, me siento más próximo, como formando parte de la pintura, ya que así puedo caminar alrededor de ella, trabajar desde los cuatro lados y estar literalmente en la pintura. Esto está cerca del método de los indios pintores de arena del oeste»... "Yo pinto sobre el suelo y esto no es extraño, y alo hacían los orientales» [10].

No es casualidad que el artista compare su trabajo, incluso lo justifique, con el comportamiento de algunos nativos americanos, como los indios navajos, que realizaban pinturas sobre la arena. Pero también en la India, donde a los suelos de tierra tradicionales se les añadía una variedad de arenas decorativas de diferentes colores. Bien se mezclaba la tierra con polvo de arroz, fariña seca y pétalos de flores, para conseguir estampados al azar; o bien se esparcía sobre el manto de tierra, controlando el diseño final, una forma de arte popular conocida como rangoli o kolam. Normalmente, durante los festivales hindúes es cuando se realizan estos diseños decorativos en el suelo de las salas de estar y en los patios, con la voluntad de que se conviertan en zonas sagradas para deidades hindúes [11].

Kazuo Shiraga (1924-2008) utilizaba todo su cuerpo para realizar pinturas de barro sobre el suelo. Shiraga, que perteneció al grupo japonés Gutai en 1955, se dedicó desde 1956 a 1966 a realizar pinturas en gran parte con sus pies. Pero también con todo su cuerpo, como en Desafiando el barro (1955). Una obra donde ofrecía una especie de combate telúrico con el barro como metáfora de la tinta y el cuerpo como pincel [12]. Un año más tarde, en la obra Pintando con los pies (1956), y ya valiéndose de la pintura, Shiraga remata la metáfora de Pollock, utilizando la extremidad del cuerpo humano más lógica para pintar sobre un lienzo situado en el suelo. Y también se puede incluir como una metáfora el trabajo de Janine Antoni (1964-), que pinta los lienzos sobre el suelo usando como pincel su propio pelo a modo de fregona, como en su obra Loving Care / Cuidado Amoroso (1992).

También se puede incluir en este apartado a otro artista del grupo japonés Gutai, como Shozo Shimamoto (1928-2013) y su obra Arrojando botellas de pintura (1956). O el trabajo de Lynda Benglis (1941-) y sus obras Contraband (1969), Corner Piece (1969) u Odalisque: Hey Hey Frankernthaler (1969) y desde luego su intervención Latex floor painting (1970) en la Universidad de Rhode Island recogida en la revista LIFE. Y desde luego, la obra Beneath Dignity (1977) de Stuart Brisley. Sobre un muelle, trazó sobre el suelo cinco marcos formados por listones de madera, para delimitar su acción. Y dentro de ellos, sobre el agua, y ayudándose de tiza, polvo de harina, pintura blanca y negra y sobre todo de su cuerpo, realizó formas que quedaron documentadas a través de las 23 fotografías que realizó su amiga Janet Anderson.

Otros artistas también se han propuesto dejar su huella -la de su propio cuerpo- sobre el suelo, como es el caso de Ana Mendieta (1948-1985) y su obra Silueta en la playa (1976). Este enredo con el suelo culminó de forma trágica cuando la artista dejó su huella real -y su vida - sobre el pavimento de Greenwich Village de New York el 8 de septiembre de 1985 cuando se precipitó desde la ventana de su apartamento en la planta 34. En ese momento estaba acom- 

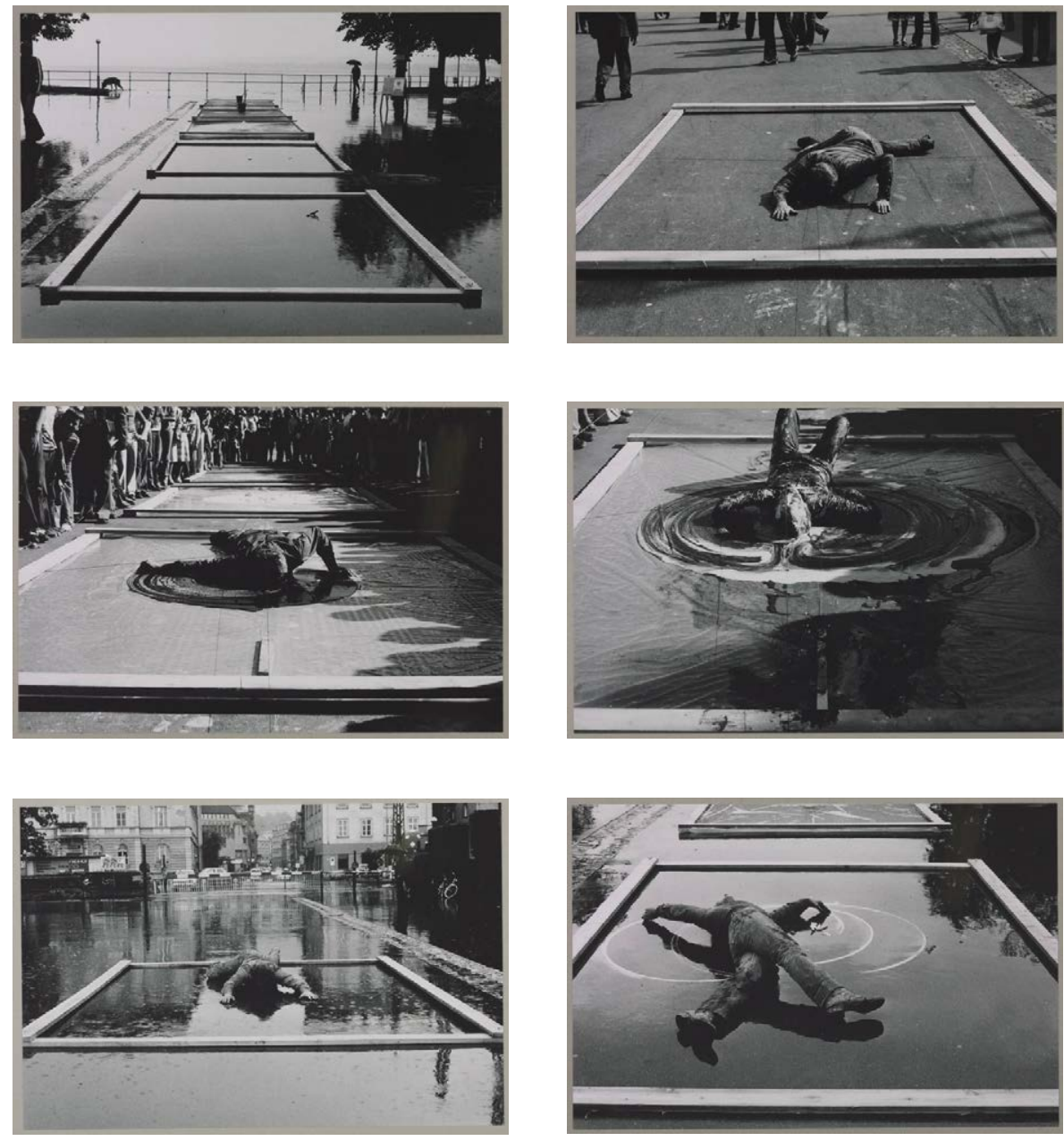

pañada de su marido, el también artista Carl André (1935-) quien incluso tuvo que declarar como acusado de un caso de violencia doméstica. Y es que más allá de que fuera un suicidio o un homicidio, los saltos - o empujones - al vacío, además de en la metáfora del arte, también se producen en la vida real. Además, resulta paradójico que precisamente la obra de André — de la que hablaremos en el Capítulo 10: «El pavimento textil. Alfombras y superposiciones»- esté también íntimamente relacionada con el suelo.

\section{Suelo hundido. Pozos de conversación}

La arquitectura moderna, pero sobre todo la producida durante la segunda mitad del siglo XX, se ha propuesto acercar el cuerpo al plano del suelo, liberándolo de convenciones. Las almohadas sobre el suelo y las alfombras peludas, parecían elementos imprescindibles para señalar hacia dónde se dirigía el futuro [13]. Pero también se trataba de liberar el plano duro del suelo de su solidez y sustituirlo por elementos textiles más simpáticos con el contacto del cuerpo humano.

A finales de los años 1960, la consagración del movimiento hippy augura un momento de experimentación, de liberación y de la aceptación de la psicodelia. Esto tiene una repercusión en el interiorismo y en la decoración de ese momento que por ejemplo se propone sustituir los asientos, los sillones y las butacas que, con su carácter burgués, se les podía relacionar con un trono regio - donde se produce una situación de prevalencia y poder de quien los ocupa-por otros elementos que socializaran la conversación de un modo más asambleario
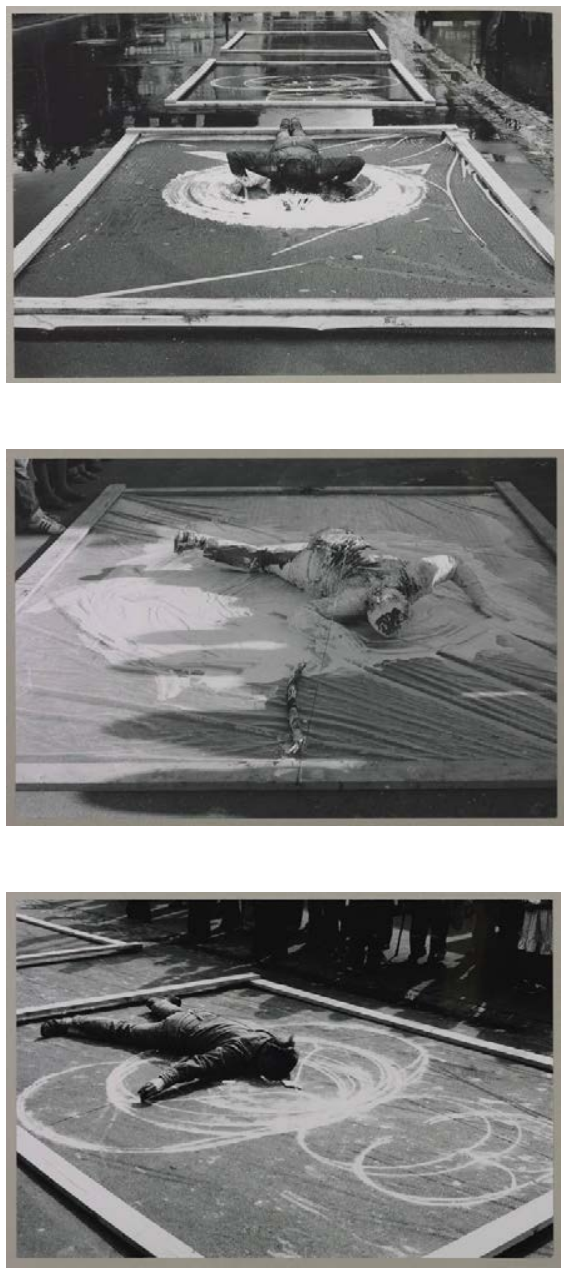

Figura 15 Beneath Dignity (1977). Stuart Brisley. [Fotografía: @Janet Anderson @TATE, Londres. T003315]

Figura 16 Loving Care / Cuidado amoroso (1993). Janine Antoni. [Fotografía: CPrudence Cumming Associates at Anthony d'Offay Gallery, Londres @Janine Antoni]

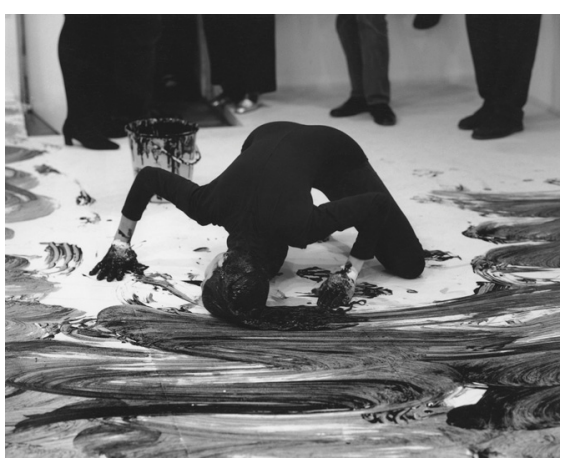



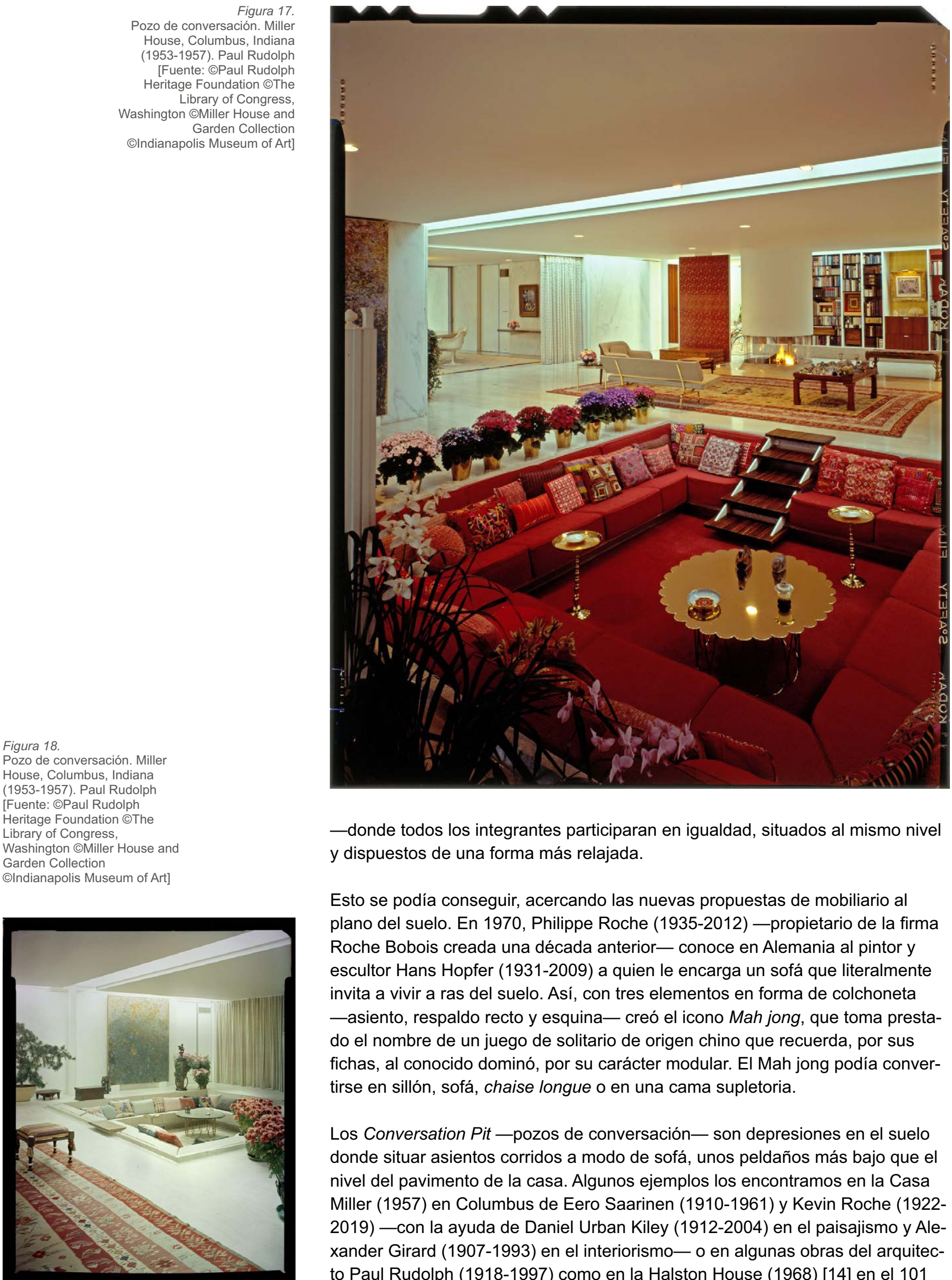

—donde todos los integrantes participaran en igualdad, situados al mismo nivel y dispuestos de una forma más relajada.

Esto se podía conseguir, acercando las nuevas propuestas de mobiliario al plano del suelo. En 1970, Philippe Roche (1935-2012) — propietario de la firma Roche Bobois creada una década anterior-conoce en Alemania al pintor y escultor Hans Hopfer (1931-2009) a quien le encarga un sofá que literalmente invita a vivir a ras del suelo. Así, con tres elementos en forma de colchoneta -asiento, respaldo recto y esquina - creó el icono Mah jong, que toma prestado el nombre de un juego de solitario de origen chino que recuerda, por sus fichas, al conocido dominó, por su carácter modular. El Mah jong podía convertirse en sillón, sofá, chaise longue o en una cama supletoria.

Los Conversation Pit — pozos de conversación- son depresiones en el suelo donde situar asientos corridos a modo de sofá, unos peldaños más bajo que el nivel del pavimento de la casa. Algunos ejemplos los encontramos en la Casa Miller (1957) en Columbus de Eero Saarinen (1910-1961) y Kevin Roche (19222019) — con la ayuda de Daniel Urban Kiley (1912-2004) en el paisajismo y Alexander Girard (1907-1993) en el interiorismo- o en algunas obras del arquitecto Paul Rudolph (1918-1997) como en la Halston House (1968) [14] en el 101 
East 63rd Street en Upper East Side, en Manhattan, New York, publicada en un reportaje fotográfico en la revista LIFE Magazine en el año 1978, donde una alfombra de color gris coloniza ese espacio deprimido del 'pozo de conversación'. Durante los 15 años que vivió Roy Halston en la casa (1974-1989) se organizaron en ella fiestas donde asistieron Andy Warhol (1928-1987) o Liza Minnelli (1946-), todos ellos pertenecientes a la atmósfera de personajes que frecuentaban el Studio 54. También la Milam House (1959-1961) en Jacksonville, Florida, igualmente proyectada por Paul Rudolph, dispone de un 'pozo de conversación'. En un artículo en la revista Architectural Record de 1961 deciden titular el apartado dedicado a esta casa 'The House of Seven Levels' y en él se dice:

«En la casa de la playa de Milam, esencialmente son una serie de plataformas, el plano del suelo cae para formar un pozo (foso) de conversación extendido en la sala de estar, que se eleva para formar una plataforma para comer, y una zona con cuatro peldaños más altos se convierte en un mirador definido por un parapeto bajo» [15].
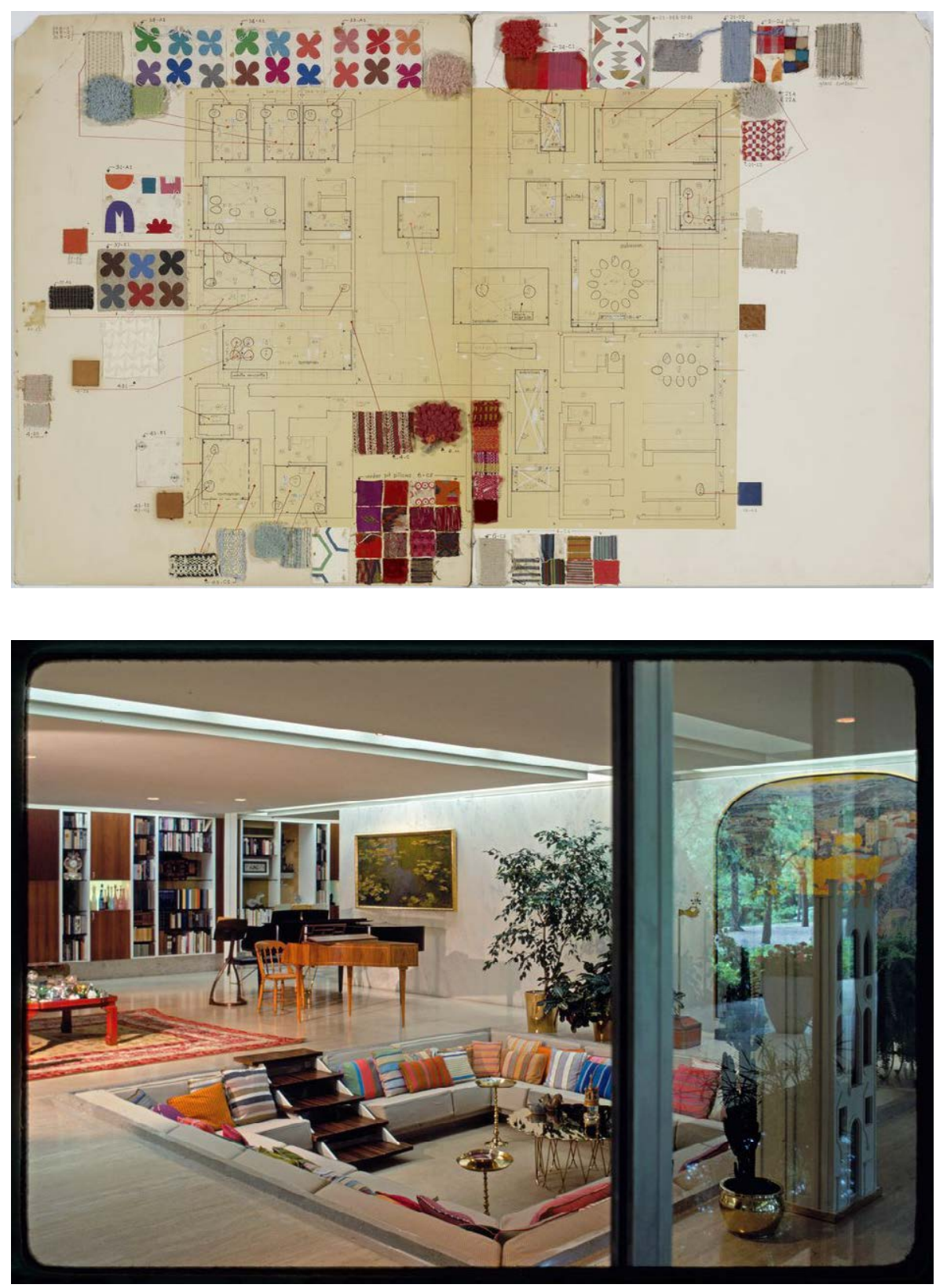

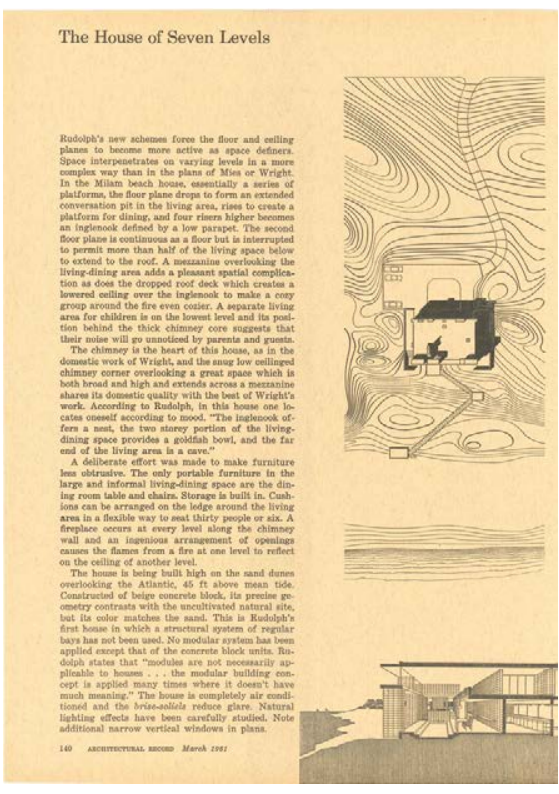

Figura 19 Artículo aparecido en la revistas Architectural Record en marzo de 1961 de la Millan House (1959-1961). Paul Rudolph. [Fuente: (C)Architectural Record]

Figura 20.

Detalle de los materiales. Pozo de conversación. Miller House, Columbus, Indiana (19531957). Paul Rudolph y Alexander Girard [Fuente: (C)Paul Rudolph Heritage Foundation (CThe Library of Congress, Washington @Miller House and Garden Collection CIndianapolis Museum of Art]

Figura 21.

Pozo de conversación. Miller House, Columbus, Indiana (1953-1957). Paul Rudolph [Fuente: (P) Paul Rudolph Heritage Foundation (CThe Library of Congress,

Washington @Miller House and Garden Collection

CIndianapolis Museum of Art]

[14] En 1974, Roy Halston compró la casa a Alexander Hirsch y su socio Lewis Turner, que habían vivido en la casa durante seis años y medio (19681974). Roy Halston vivió durante 15 años en la casa (1974-1989).

[15] «Four current projects by Paul Rudolph». Architectural Record. Building Types Study 292 Apartments. New York: McGraw Hill , march 1961, núm. 292, pp. 139-154.

[16] Lara-Ruiz, Manuel de. «Can Lis. La huella de la arquitectura de J örn Utzon a través de su obra Can Lis». Director: Alberto Morell-Sixto. Madrid: Universidad Politécnica de Madrid, Escuela Técnica Superior de Arquitectura, Departamento de Proyectos Arquitectónicos, 2015. 


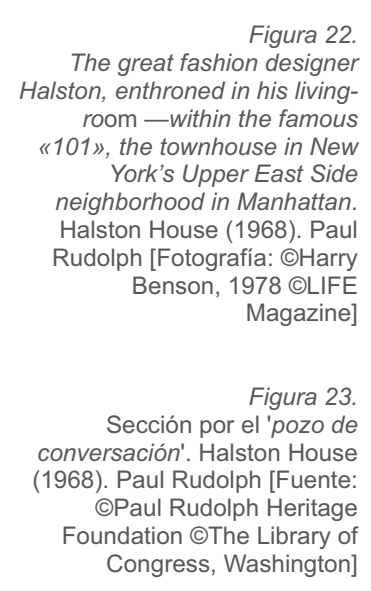

Figura 24.

Rudolph residence, 31 High

Street, New Heaven,

Connecticut. Living area

(c1963). Paul Rudolph [Fuente:

CPaul Rudolph Heritage

Foundation @The Library of

Congress, Washington]

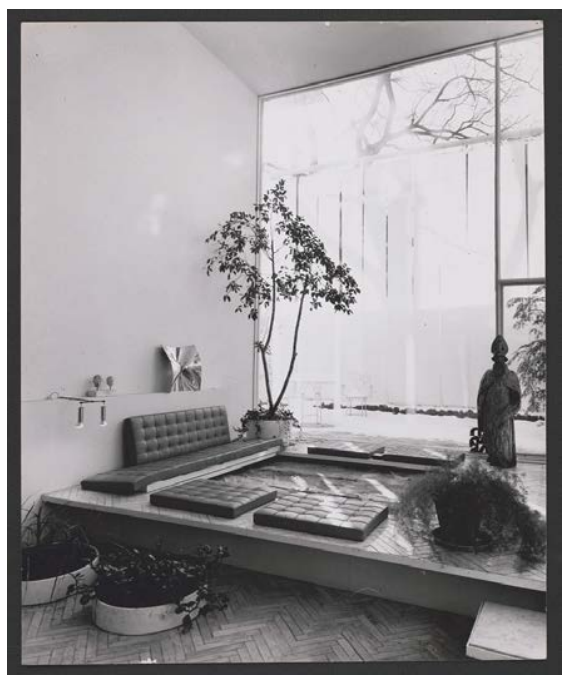

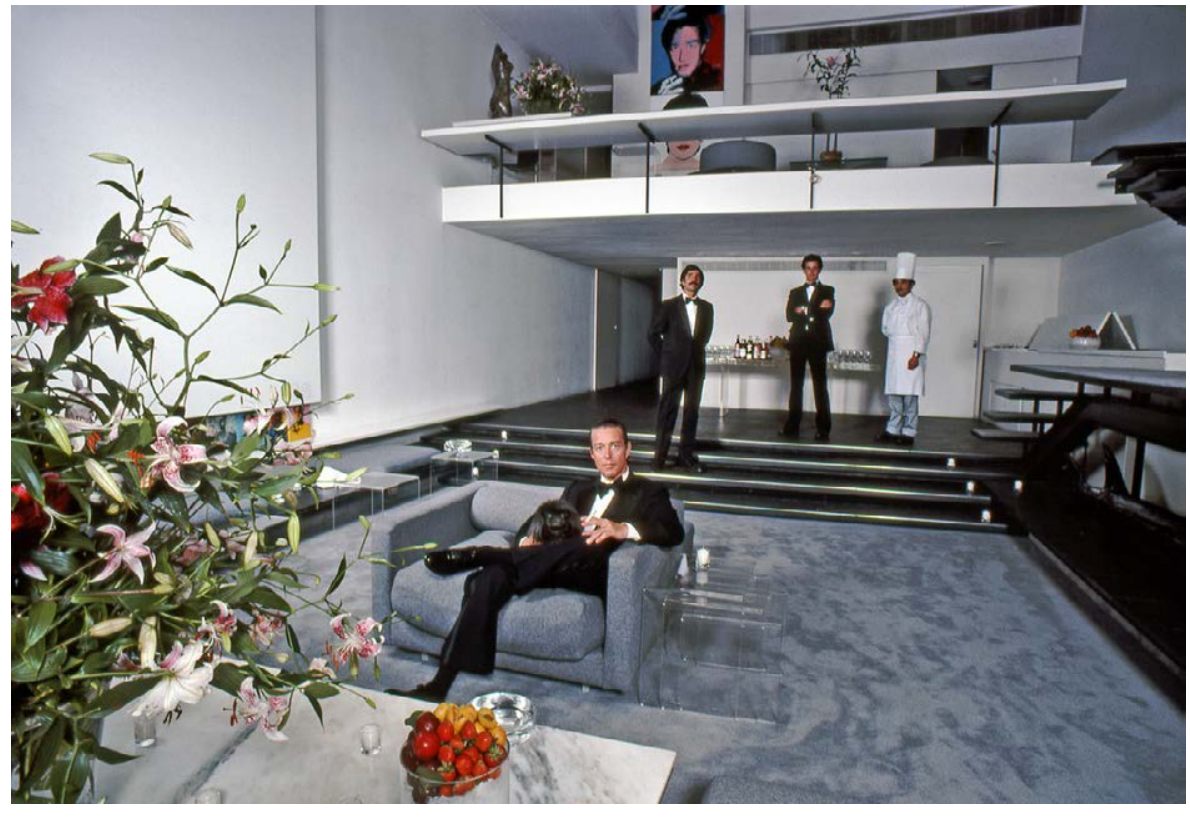

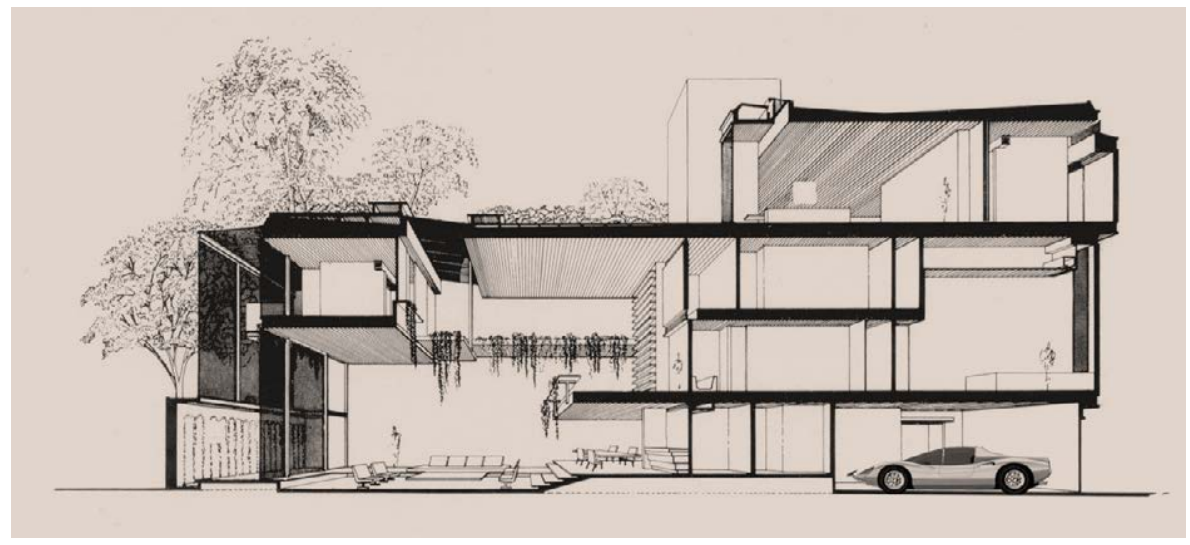

\section{Plataformas}

También encontramos en los archivos de Jørn Utzon (1918-2008) algunos bocetos y dibujos sobre propuestas de 'pozos de conversación' en Can Lis (19701974), su refugio en Mallorca, construido después de terminar en el proyecto de la Ópera de Sidney en 1966. Y en otros bocetos, también se muestra una modificación del plano del suelo, pero esta vez estableciendo una pequeña plataforma elevada tres peldaños sobre el nivel del pavimento del salón.

«Es así, natural, sin misterios. El mismo orden que hay arriba, en el techo, está en el suelo, abajo en el pavimento. Los elementos y la reflexión son claves para buscar la solución final, 'in situ', desde la serenidad, sin artificios» [16].

Pero antes de ese proyecto, durante un viaje de estudios a México en 1949, Utzon descubrió la gran variedad e plataformas mayas en la península de Yucatán: tanto por su tamaño, como por su concepción, al encontrarse algunas aisladas y otras, rodeadas de naturaleza. Los dibujos que realiza de ellas, uno sobre la Plataforma maya en Yucatán y otro sobre el Monte Albán —además de un croquis de un templo chino- muestran la autoridad con la que el plano horizontal se eleva sobre la selva. Para él, la plataforma como elemento arquitectónico, resulta algo fascinante: «irradia de ellas una gran fuerza. Cuando uno las siente 


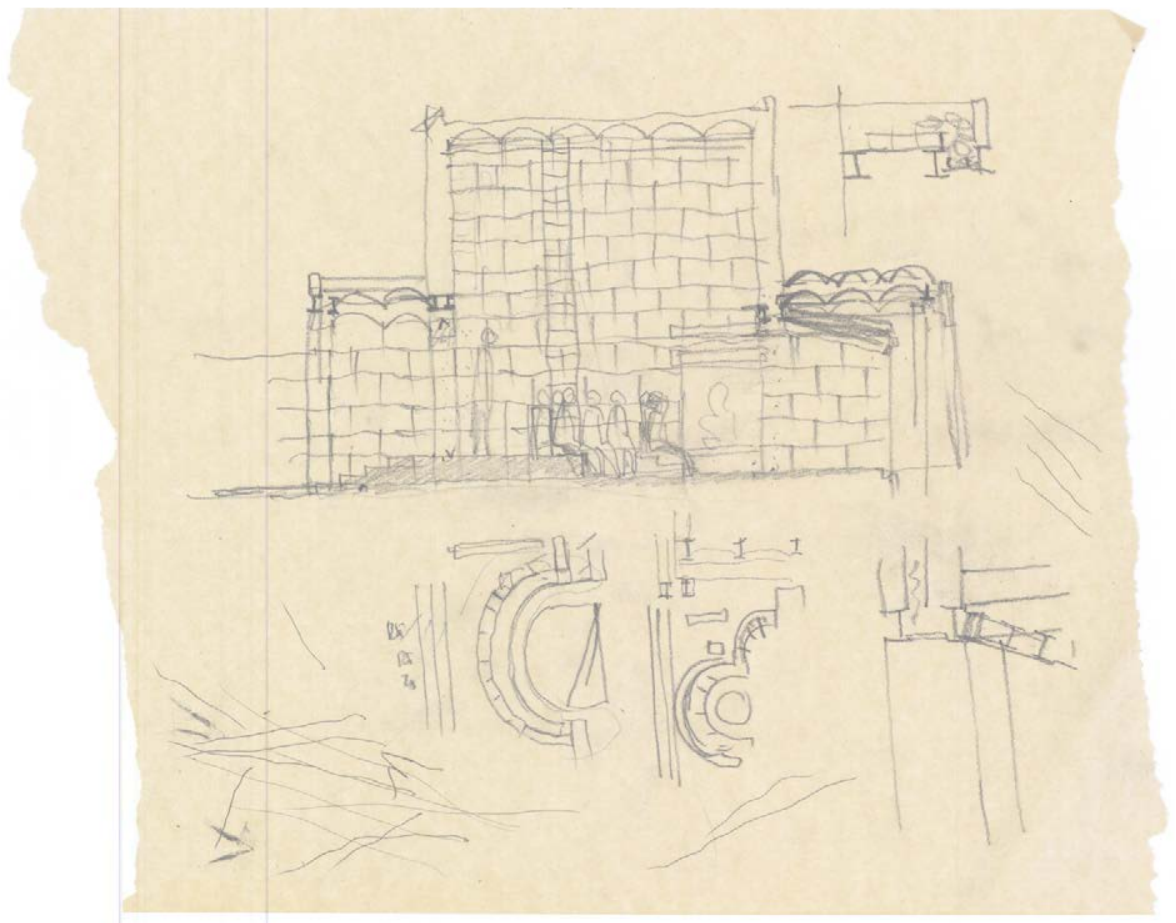

bajo los pies, experimenta la misma sensación de firmeza que emana de un macizo rocoso» [17].

La región de Yucatán, en Uxmal en el Chichen Itza, es una planicie cubierta por una selva prácticamente inaccesible, un bosque de altura uniforme, donde los mayas se establecieron. No existía visiones más allá de la jungla calurosa y húmeda. Las plataformas, construidas por artistas, expresaron por un lado sensibilidad con el entorno natural, potenciándolo; y por otro, les permitieron descubrir un nuevo punto de vista sobre la cota de los árboles, estableciendo una nueva relación con los dioses. Así, sobre las estas plataformas —que algunas alcanzaban el centenar de metros de altura - los mayas construyeron sus templos y tenían acceso al cielo, al viento y al horizonte.

La arquitectura nace del acuerdo entre la ordenación de las huellas sobre el suelo y de las coberturas. La traza sobre el suelo establece ya un lugar, un vestigio, una señal, una emergencia sobre el paisaje. Para Frank Lloyd Wright, 'la tierra', es decir, 'el suelo' es «la forma más simple de la arquitectura» [18].

La plataforma y el suelo elevado, han sido el modo en el que los templos, los palacios, la arquitectura religiosa y la arquitectura doméstica han separado lo limpio de los sucio, lo sagrado de lo profano, los gobernantes de los gobernados, y los administradores de los administrados [19]. Así les ocurría a los tribunos en la antigua Roma.

También la Academia ha elevado los suelos para situar a los profesores, a los maestros y a los líderes intelectuales, y así poder dirigirse hacia los alumnos o hacia los espectadores . La aristocracia, la realeza, la iglesia y las organizaciones sociales y políticas, también han insistido en situar a sus líderes —algunos ungidos o auto-proclamados, otros elegidos- en posiciones exaltadas respecto a los demás, en suelos y en tarimas elevados.

Incluso en las viviendas neolíticas, una superficie de madera establecía un nuevo plano respecto a la mezcla de piedras y guijarros que formaban el pavi-
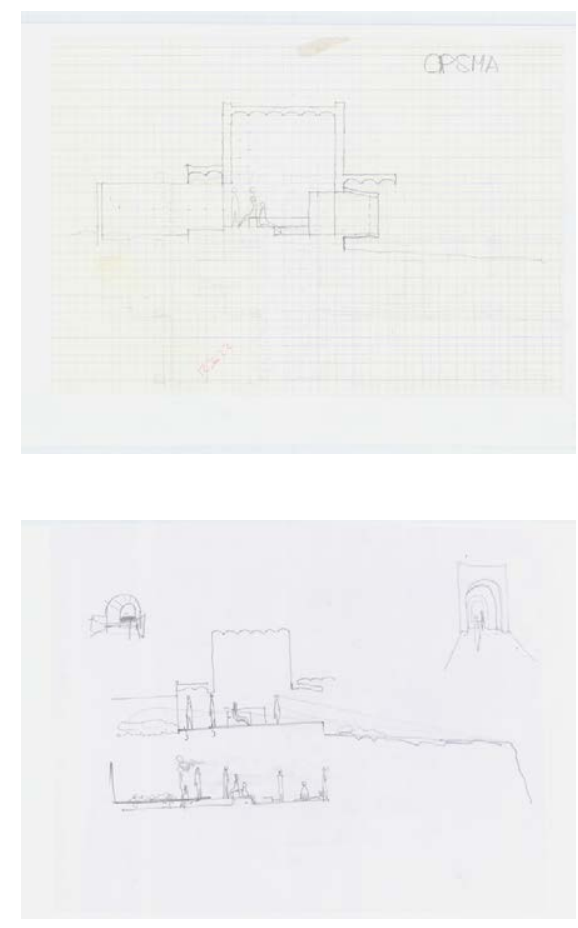

Figura 25

Croquis de Can Lis en Mallorca donde se estudia la posible incorporación de un 'pozo de conversación' y de unas plataformas elevadas dentro del salón (1970-1974). Jörn Utzon. [Fuente: (OThe Utzon Archives]

Figura 26 Jörn Utzon durante la construcción de Can Lis (19701974). [Fotografía: (TThe Utzon

Archives]

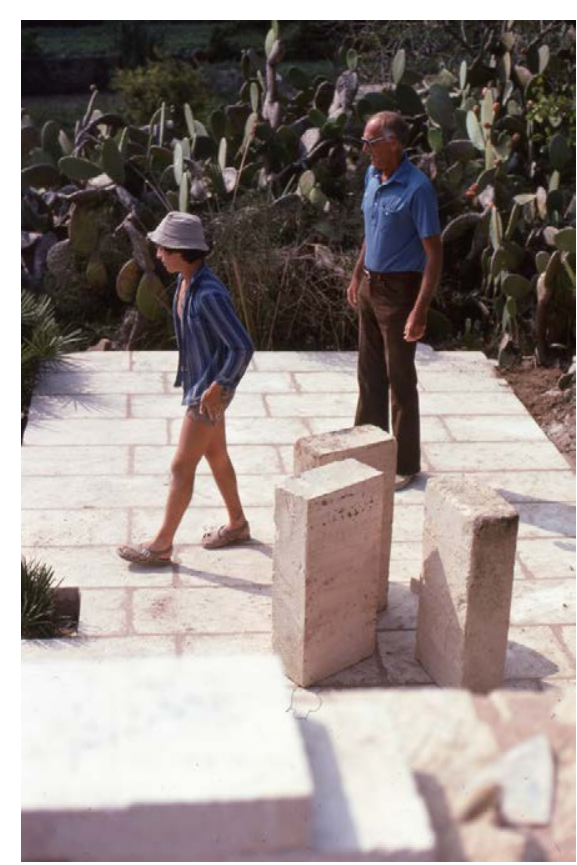


mento del suelo. A lo largo de la historia, en la organización del espacio, sobre todo en la sección, queda un remanente gusto residual por la jerarquía, siendo el suelo, tanto por su tratamiento, como por su posición elevada, el encargado de subrayarla.

Los planos horizontales elevados han sido un punto de observación privilegiado como un lugar para la observación, para el control, para la seguridad y para el poder de las personas.

«A lo largo de la historia, el hombre se ha esforzado por conseguir planos horizontales lo más extensos posible. Para ello ha realizado movimientos de tierras y [ha] construido grandes muros de contención, con la intención de establecerse en cotas relativamente altas donde pueda la vista dilatarse hasta la lejanía» [20].

El Yingzao Fashi, cuya traducción, más o menos literal, puede ser: 'Tratado sobre métodos de arquitectura o las normas de construcción del Estado' es un tratado técnico sobre artesanía y arquitectura, escrito por el autor chino Li Jie (1065-1110). En los 34 capítulos del libro, contextualizados a mediados de la dinastía Song de China (960-1279), se desarrollan con detalle las unidades de medida, la construcción de fortificaciones y fosos o normas para la construcción de mamposterías o artesanías de madera. $Y$ desde luego directrices para la construcción de suelos y pavimentos, a veces, acompañados de ilustraciones. Estableció métodos e instrucciones para la fabricación de baldosas, proponiendo criterios de composición y de esmaltado, así como las tecnologías relacionadas con el secado en el horno. También estableció criterios sobre cómo endurecer o pulir las baldosas frotándolas con talco u hollín, además de explicar las técnicas para pintar o estampar patrones —éstas últimas, reservadas para tumbas o santuarios [21].

En el tratado se explica una fórmula de glaseado con óxido de metal utilizado durante la dinastía Song (960-1279): al igual que la baldosa encáustica utilizada

[17] Utzon, J örn. «Platforms and Plateaus: Ideas of a Danish Architect». Zodiac. Milán: Edizioni di Comunità, julio 1962, núm. 10.

[18] Lloyd-Wright, Frank. The future of architecture. New York: Horizon Press, 1953.

LLoyd-Wright, Frank. El futuro de la arquitectura. Buenos Aires: Poseidón, 2008.

[19] Koolhaas, Rem (ed.) y Easterling, Keller. «Floor». En: Elements of architecture. The Venice Biennale. 14th International Architecture Exhibition. Venezia: Marsilio Editori, 2014. p. 24.

[20] Bermejo-Goday, J esús. «El espacio arquitectónico como extensión heterogénea. Una contribución a la obra de Juan Borches». Director: Francisco-J avier Sáenz de Oíza. Madrid: Universidad Politécnica de Madrid, Escuela Técnica Superior de Arquitectura, Departamento de Proyectos Arquitectónicos, 1987.

[21] Koolhaas, Rem (ed.) y Easterling, Keller. «Floor». Op. Cit. p. 160.

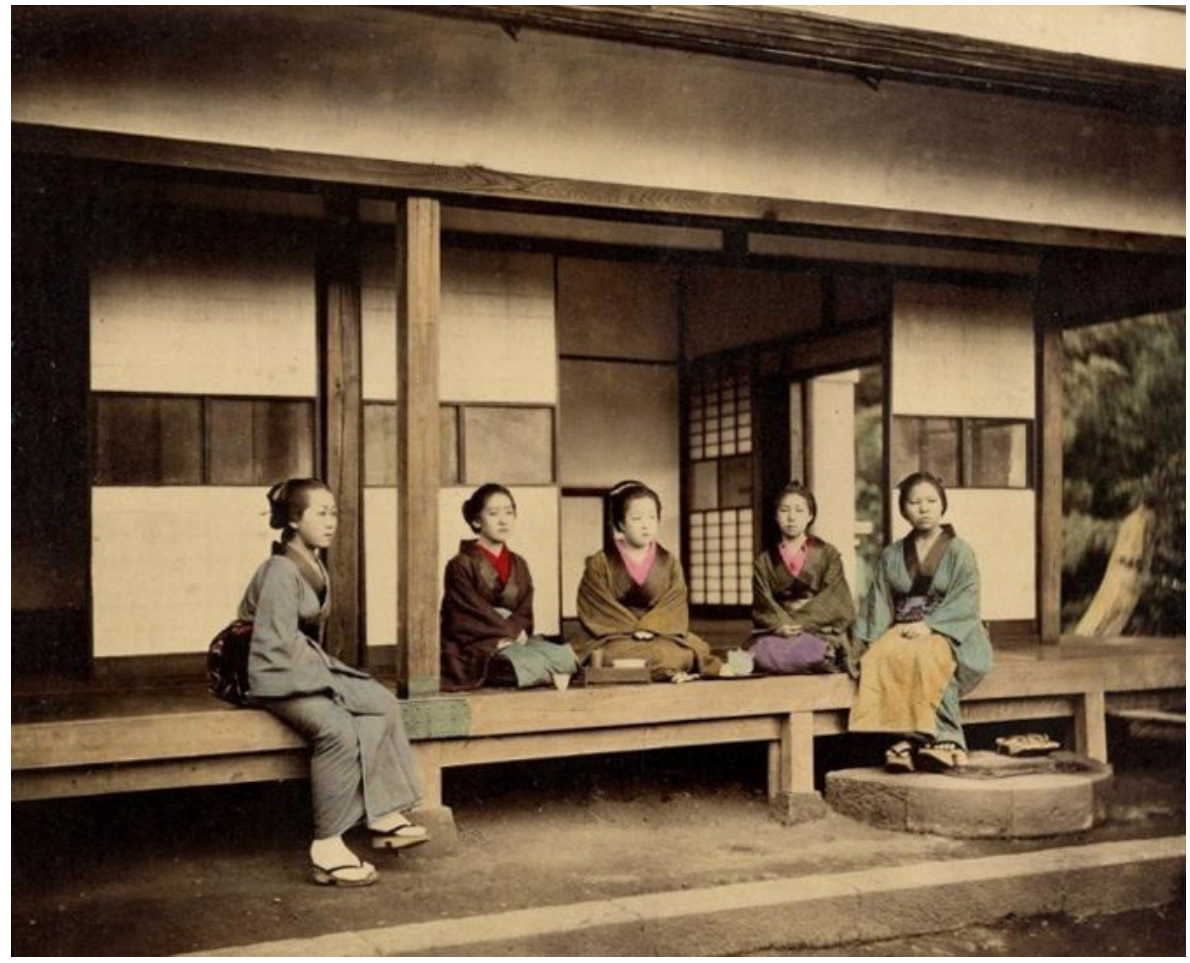



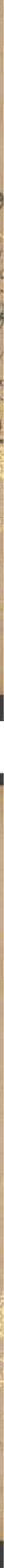

en Europa durante el siglo XIII, ésta se formó con diferentes colores de arcilla, de tal modo que se podía conseguir un patrón de diseño sin incrustaciones [22]. El Yingzao Fashi registró técnicas que se habían practicado durante siglos y se transmitían, primero oralmente y luego escritas en verso. También aparece un trabajo de investigación sobre la tradición china de suelos elevados, pagodas y 'gate towers' que de algún modo celebraban la presencia de gobernantes y deidades [23].

"Las viviendas y los templos chinos deben mucho a la sensación de firmeza y seguridad que transmiten al hecho de que se apoyan sobre una plataforma, elemento que suele tener las mismas dimensiones que el techo, o a veces mayores, de acuerdo con la importancia del edificio. El juego entre la cubierta y la plataforma produce un efecto mágico. El suelo en las casas tradicionales japonesas es una delicada plataforma tratada como si fuera un puente. Es algo así como la tapa de una mesa. Es un mueble» [24].
Figura 28. Genii Monogatari Emaki. Handscrolls of the Tale of Genji. Scroll I (1660). [Fuente: @The New York Public Library]

[22] Guo, Qinghua. «Tile and Brick making in China: a Study of the 'Yingzao Fashi'». Construction History. Cambridge: The Construction History Society, Department of Architecture, Cambridge University, 2000, vol. 16, pp. 3-11.

[23] Koolhaas, Rem (ed.) y Easterling, Keller. «Floor». En: Elements of architecture. The Venice Biennale. 14th International Architecture Exhibition. Venezia: Marsilio Editori, 2014. p. 25.

[24] Utzon, Jörn. «Platforms and Plateaus: Ideas of a Danish Architect».Zodiac. Milán: Edizioni di Comunità, julio 1962, núm. 10. 


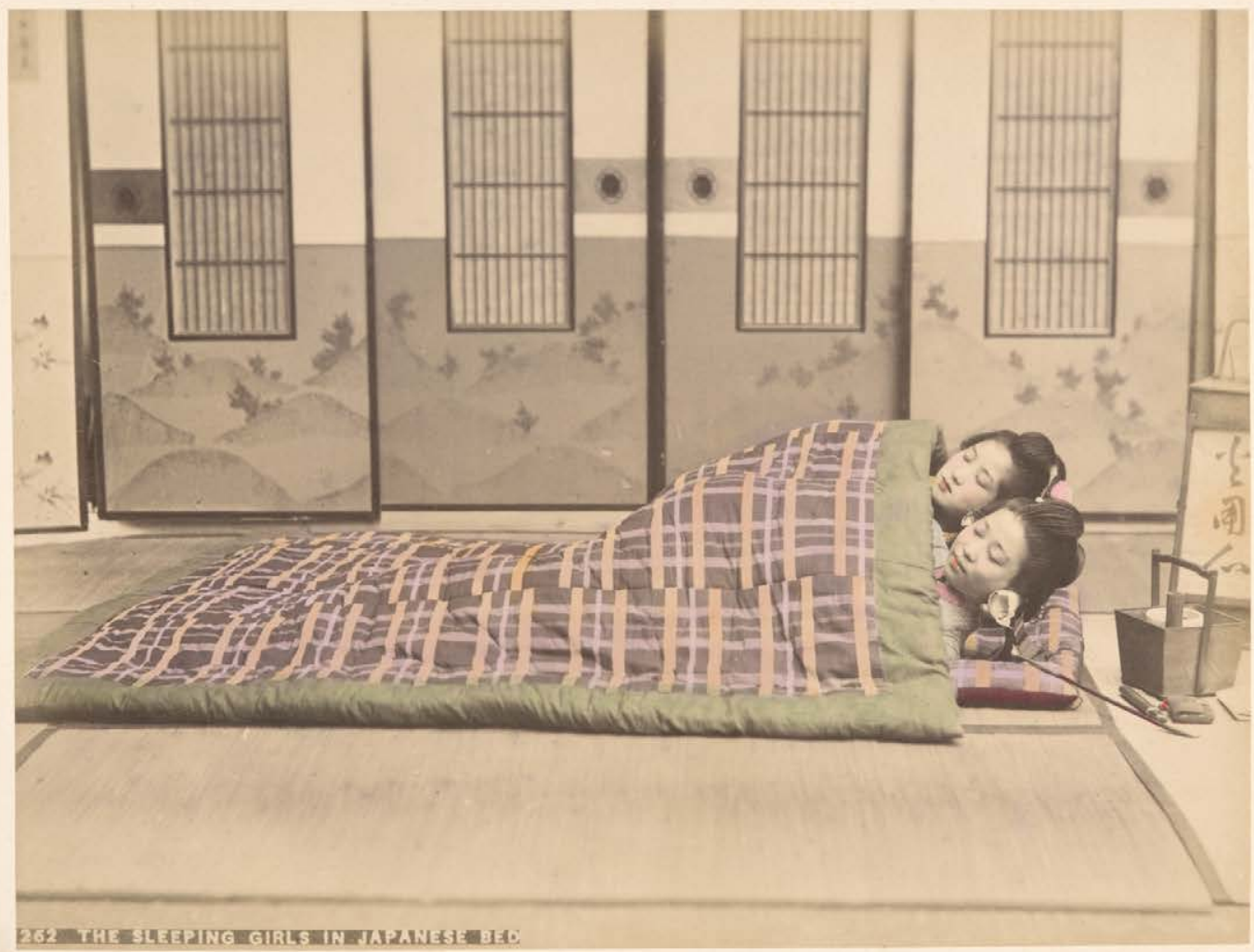

Figura 29.

The Sleeping Girls in Japanese Bed (1890s). [Fuente: @The New York Public Library. Digita Collections]
[25] Molina-Rodríguez, Santiago de. «Elogio del suelo». En: Múltiples estrategias de Arquitectura. Madrid: Ediciones asimétricas, 2013. p. 47.

[26] Taut, Bruno. La casa y la vida japonesas. Barcelona: Fundación Arquia-Caja de Arquitectos, 2007. Colección Arquia/temas, número 19.

[27] Taut, Bruno. Ibíd. p. 81.

[28] Molina-Rodríguez, Santiago de. Op. Cit. p. 47.
Pero quizá una cultura como la de Japón ha sido de las que más se ha empeñado en establecer una relación íntima entre los pavimentos y la capacidad de reflexión. Y es que caminar por las arquitecturas niponas significa pensar irremediablemente en los pies, en el cuerpo y en el contacto entre éstos y el pavimento [25]. Entre 1933 y 1936, casi en el ocaso de su vida, Bruno Taut (18801938) residió en Japón con la voluntad de conocer la cultura y la arquitectura del país del Sol Naciente; pero también sus costumbres. Residió en una pequeña casa Senshintei, junto al templo de Shorin-san, en las afueras de Takasaki y donde él mismo cinceló en una piedra conmemorativa: Ich liebe die japanische Kultur (Amo la cultura japonesa). Fruto de esa estancia escribió Das japanische Haus und sein Leben / La casa y la vida japonesas [26]. En él dedicaba su atención a la fisionomía del pie japonés, al uso de algunos tipos de calzado y al suelo irregular: «Los pies japoneses se deslizan por el suelo; el pie recibe su fuerza de él» [27]. Por ejemplo, en los jardines japoneses el uso de gravas sueltas, de pedruscos o de guijarros en un camino dificultan el paso y pretenden una comprensión diferente del paisaje [28]. Y es que quizá esas dificultades pretenden que se pose la mirada sobre loe elegantes surcos del suelo.

Shinden-Zukiri se refiere al estilo de arquitectura doméstica japonesa desarrollada en mansiones palaciegas o aristócratas construidas en el periodo Heian (794-1185). En el estilo Shinden-Zukiri los suelos eran mayoritariamente de madera, como una superficie para caminar y sentarse, pero el tatami era usado sólo por la nobleza para sentarse (mover donde los tatamis debajo).

Las primeras viviendas, situadas en los arrozales y cuya cubrición se resolvía con juncos, incorporaron pronto plataformas, como las que usan los agricultores para proteger del agua las reservas de granos. Las casas mantenían una plata- 
forma elevada como una superficie limpia donde poder sentarse y donde poder dormir, incluso cuando situaban las cocinas sobre el lecho de tierra [29].

Arata Isozaki (1931-), en el artículo «Floors and Internal Spaces in Japanese Vernacular Architecture: Phenomenology of Floors» señala que: «las áreas con suelo de tierra que eran extensiones del suelo exterior fueron abandonadas, $y$ todo el edificio se convirtió en un tipo de mueble descomunal» [30]. Para él, el suelo de la arquitectura del periodo Shinden-Zukiri (794-1185) era una superficie de gobierno. La forma de ocupar el suelo dio forma a la morfología de toda la casa. Así, como respuesta a la posición del cuerpo sentado sobre el suelo, se produjo una disminución de la altura del techo. También la disposición de las ventanas de forma horizontal incorporó una nueva cultura visual [31].

«En las casas japonesas nos atraen los suelos, así como en las casas europeas nos atraen las paredes. En una casa europea uno quiere sentarse junto a la pared, en el Japón desea sentarse sobre el suelo, más que caminar sobre él. La vida, en los hogares japoneses, se expresa en los movimientos de recostarse o caminar casi a gatas» [32].

La vivienda japonesa se desarrolla de una forma abierta y por adición de espacios independientes que de algún modo la asemejan a la planta libre finalmente retomada en Occidente por el Movimiento Moderno [33].

Los primeros tatamis (palabra que originalmente significada 'doblar y apilar') -esteras de junco tejido, aunque los tradicionales se realizaban con paja de arroz y se cerraban perimetralmente con un brocado de tela- se fabricaban de diferentes tamaños como un sistema para clasificar y jerarquizar tanto a los habitantes como a los invitados, ya que eran un lujo reservado para la nobleza. En su origen, eran más finos, lo que permitía que fueran doblados con más facilidad.

La vivienda tradicional japonesa está determinada por un sistema rígido de medidas, basado en las del tatami del suelo y el shoji -la puerta corredera de papel que es el elemento que regula las relaciones entre los distintos espacios- El módulo determinó también la cuadrícula estructural de toda la vivienda. El principio modular, que se lleva tanto a la superficie horizontal de la planta como a la sección, termina por convertirse en una 'gramática estructural' que

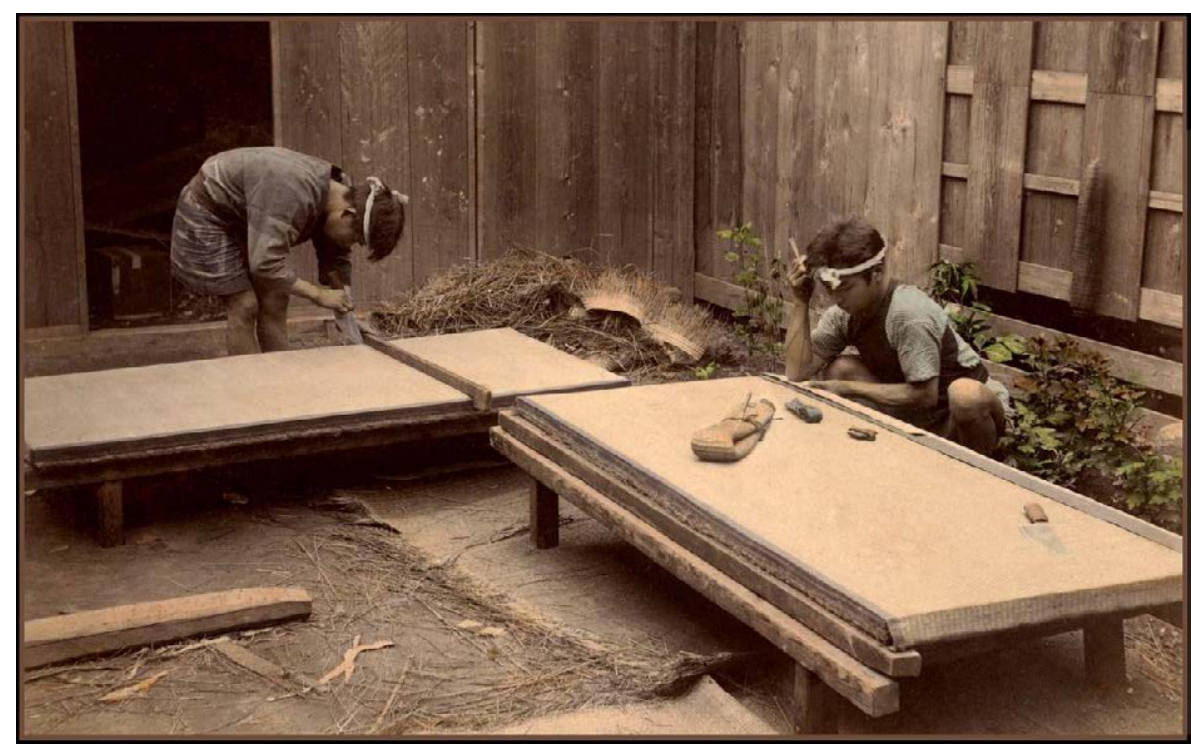

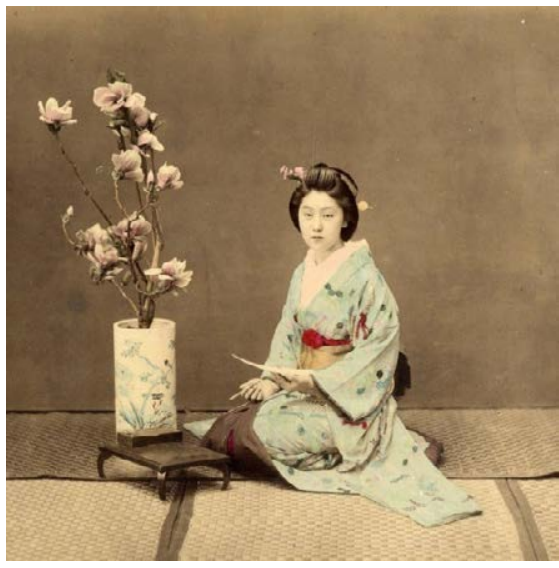

Figura 30 . Japan caught in colour back (1865). [Fotografía: CFelice Beato]
Figura 31.

The TATAMI mat makers of old Japan (1893). [Fotografía: (CK. Kimbei. 326]
[29] Koolhaas, Rem (ed.) y Easterling, Keller. «Floor». En: Elements of architecture. The Venice Biennale. 14th International Architecture Exhibition. Venezia: Marsilio Editori, 2014. p. 26.

[30] Isozaki, Arata. «Floors and Internal Spaces in J apanese Vernacular Architecture: Phenomenology of Floors». RES: Anthropology and aesthetics. New York: Peabody Museum of Archeology and Ethnology, Harvard University, spring 1986, vol. 11, pp. 54-77.

[31] Koolhaas, Rem (ed.) y Easterling, Keller. «Floor». Op. Cit. p. 28.

[32] Utzon, Jörn. «Platforms and Plateaus: Ideas of a Danish Architect». Zodiac. Milán: Edizioni di Comunità, julio 1962, núm. 10.

[33] Deplazes, Andrea (Ed.). Construir la Arquitectura. Del material en bruto al edificio. Un manual (Architektur konstruieren. Vom Rohmaterial zum Bauwerk. Ein Handbuch). Barcelona: Editorial Gustavo Gili y ETH Zúrich, 2010. p. 112. 


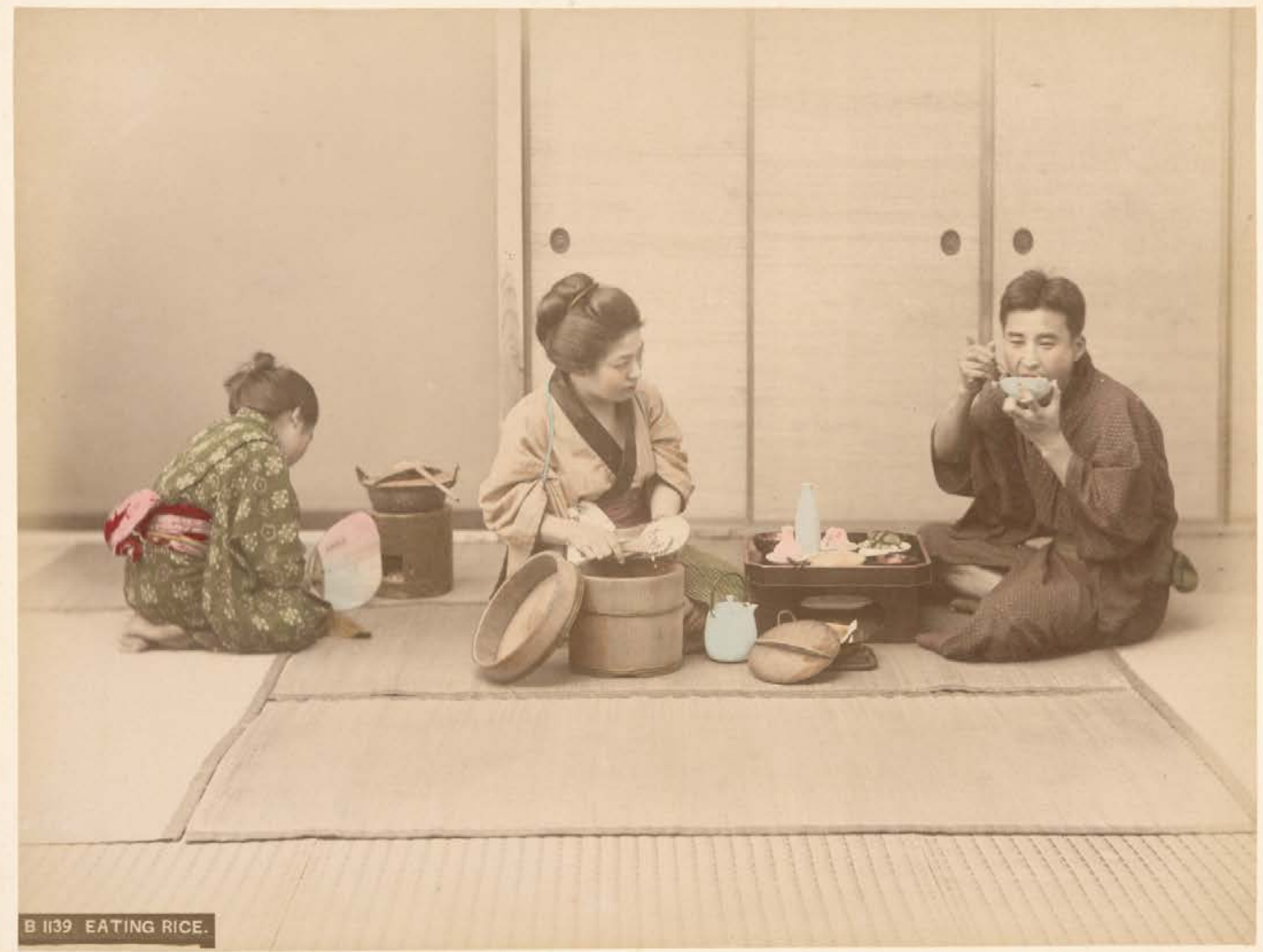

Figura 32.

Eating Rice (1890s). [Fuente: CThe New York Public Library. Digital Collections]
[34] Deplazes, Andrea (Ed.). Construir la Arquitectura. Del material en bruto al edificio. Un manual (Architektur konstruieren. Vom Rohmaterial zum Bauwerk. Ein Handbuch). Barcelona: Editorial Gustavo Gili y ETH Zúrich, 2010.p. 112.

[35] Ibíd. p. 111.

[36] Kodansha Encyclopedia of J apan. Tokyo: Kodansha, 1983. alcanzó su cénit en el Palacio Imperial de Katsura (S. XVII), en Kioto [34]. Los tatamis dictaron el tamaño y las proporciones de las habitaciones, distinguiendo habitaciones de cuatro, seis, ocho esteras, o incluso más.

Siempre que sea posible, la disposición de los tatamis evita el cruce de cuatro líneas, es decir, en cuadrícula o que en un punto coincidan tres o cuatro esquinas de una estera. Por ejemplo, la combinación de ocho tatamis con líneas de cruce, se reserva exclusivamente para usos representativos; o las de cuatro tatamis (y medio) es la combinación que se destina a las estancias donde se celebra la Ceremonia del Té [35].

Después del periodo Kamakura (1192-1333), la arquitectura japonesa evolucionó hacia el Shoin-Zukuri, estilo de arquitectura residencial japonés usado en las mansiones de los militares las casa de sacerdotes y samurais durante el periodo Azuchi-Momoyama (1568-1600) y durante el periodo Edo (1600-1868):

«El estido Shoin-Zukuri fue la incorporación de postes cuadrados y suelos completamente cubiertos con 'tatami'» «El estilo toma su nombre del shoin, un término que originalmente significaba un estudio y un lugar para conferencias sobre el sütra dentro de un templo, pero que más tarde llegó a significar solo un salón o estudio» [36].

En el periodo Muromachi o Ashikaga (1336-1573), los tatamis, ya de proporción 2:1, fueron dimensionados para acomodar a dos personas sentadas — con medidas aproximadas de 1x2 metros (0,995x1,91 m en la zona de Kyoto, $0,88 \times 1,76 m$ en Tokyo)—Al principio, sólo se incluía en habitaciones pequeñas y poco a poco fue colonizando el resto de los espacios de la casa, hasta que 
aparecieron los zashiki: habitaciones completamente realizadas con tatami [37]. Los tatamis, que cubrieron las plataformas y los suelos, sirvieron de base para situar la ropa de cama de los lugares vinculados con el descanso nocturno.

El periodo Edo o Tokugawa (1603-1868) se caracterizó por una proliferación de una habitación llamada Shoin. En ella se produce una transformación de las proporciones tradicionales, tanto de los espacios como de los anchos de los vanos, produciendo a su vez un cambio en la conformación del suelo.

En el siglo XVII, los tatamis se popularizan de forma transversal en todo el estrato social japonés, perdiendo su condición de objeto de lujo. En la crisis de vivienda de la posguerra, las viviendas sociales mínimas todavía se expresaban con la unidad modular del tatami, llegando a la arquitectura contemporánea en Japón [38]. Si bien, no todas las habitaciones disponen de tatami, siempre se reserva un pequeño espacio en la casa donde disponerlos, llamado nihonma o washitsu —es decir, 'habitación de estilo japonés'.

\section{Ceremonia del Té}

En el siglo XV se originó y se desarrolló en Japón la Ceremonia del Té, convirtiendo su degustación en una religión estética: el teísmo. El primer salón de té aislado se le debe a Sen no Rikyú (1522-1591), en además instituyó las formalidades. La Ceremonia del Té es de los pocos ejemplos de ritualización y mecanización de un impulso estético, y que ha llegado a ser el símbolo de Japón. La casa de Té (en japonés Sukiya — La Morada de la Fantasía, La Morada del Vacío y La Morada de lo Asimétrico-) es una choza o habitáculo agrícola, una habitación de paja. Originalmente era una zona más de la sala de visitas común, separada del resto mediante un biombo. A esta parte del recibidor segregada se le conoce con el nombre de kakoi (reservado) nombre con el que todavía se nombra a los salones de té dispuestos en una casa [39].

El Sukiya está compuesto por el salón de té con capacidad para recibir a cinco personas, y una ante-cámara (Misuya) donde se produce la limpieza y prepara-

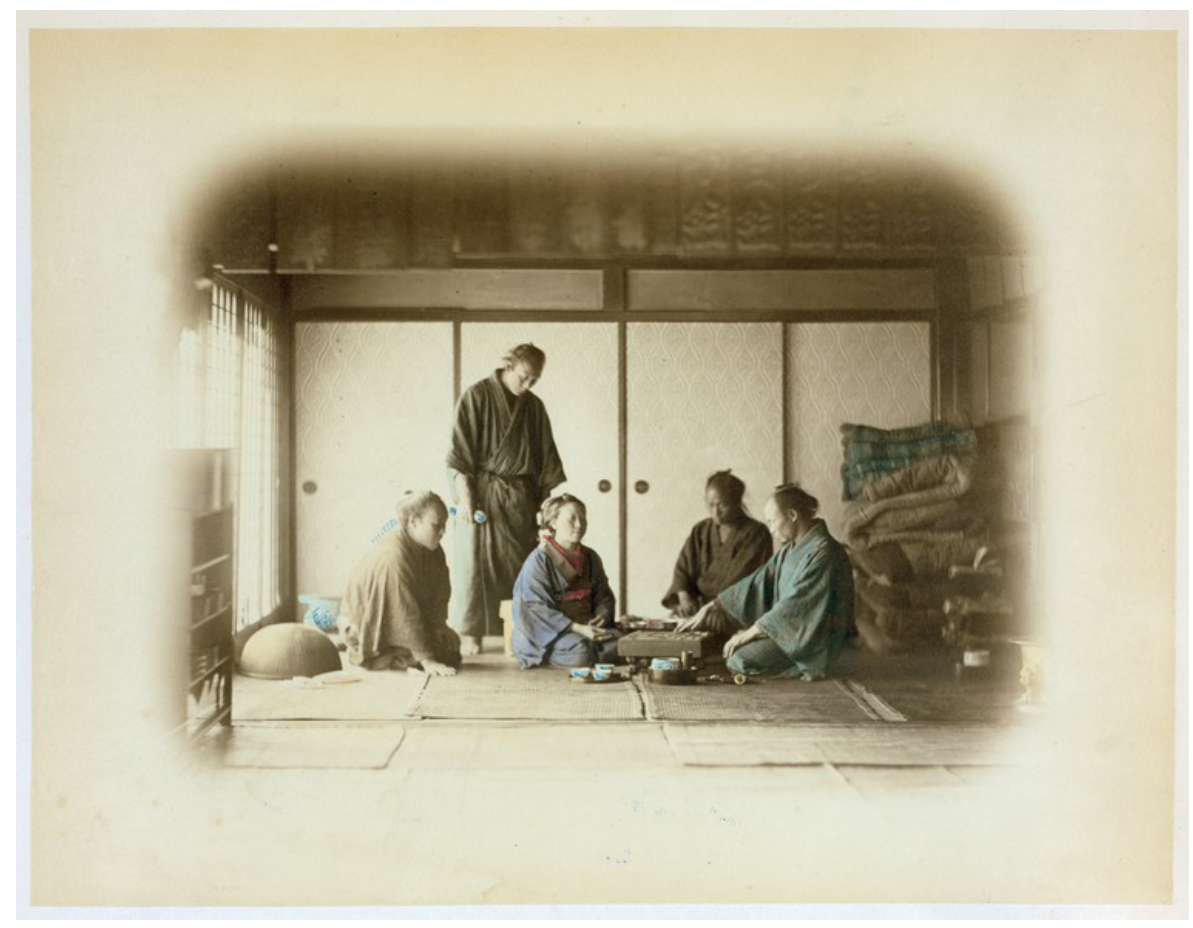

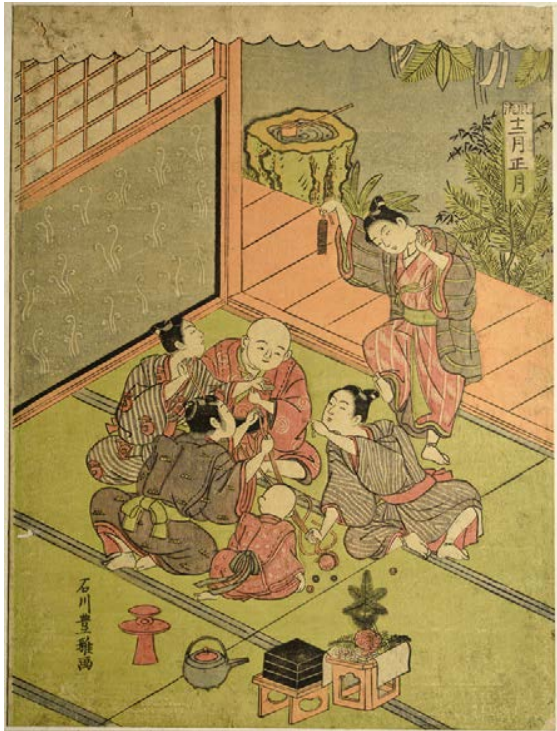

Figura 33.

A group of five boys seated on the floor of a house playing fortune drawing (Fukubiki), shile a sixth boy dances about behind them holding up a string of cash (1770). Ishikawa Toyomasa [Fuente: (CThe New York Public Library. Digita Collections]

Figura 34.

Interior of a Japanese tea

house (1870s). [Fotografía:

(CFelice Beato @The New York

Public Library. Digital

Collections]
[37] Prieto-González, Nuria. «Tatamis». Tectónica. La Coruña: ETSAC, 13 de septiembre de 2013.

[38] Tadashi-Oshima, Ken. «Postulating the Potential of Prefab: The case of J apan». En: Bergdoll, Barry y Christensen, Peter (Eds.). Home Delivery: Fabricating the Modern Dwelling. New York: MoMA-The Museum of Modern Art, 2008.

[39] Palacios-Díaz, Dolores. «Cuerpo, distancias y arquitectura. La percepción del espacio a través de los sentidos». Directores: Antonio Miranda-Regojo y Nicolás-Maruri González de Mendoza. Madrid: Universidad Politécnica de Madrid, Escuela Técnica Superior de Arquitectura, Departamento de Proyectos Arquitectónicos, 2014.stavo Gili y ETH Zúrich, 2010. p. 112. 